

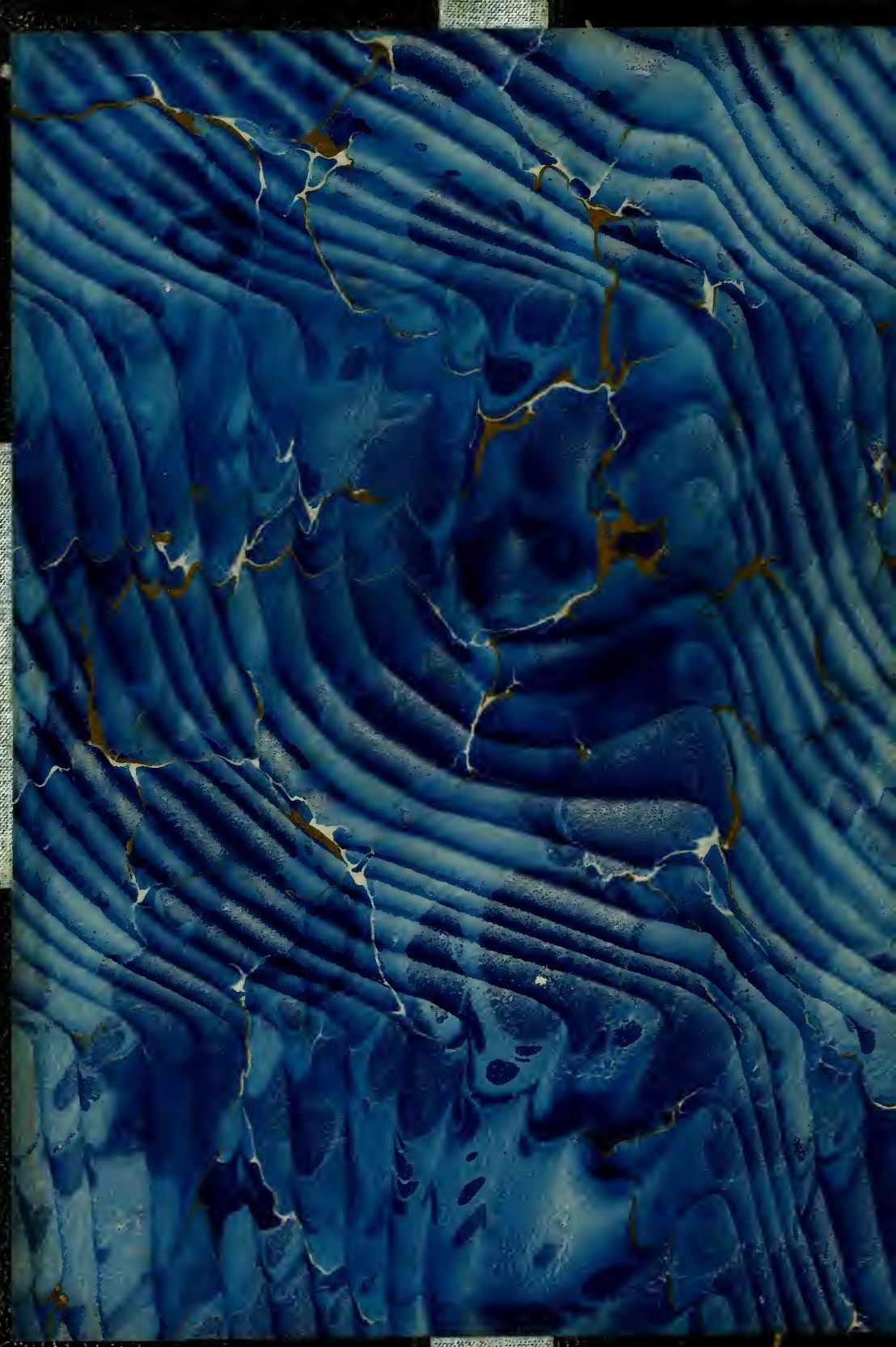




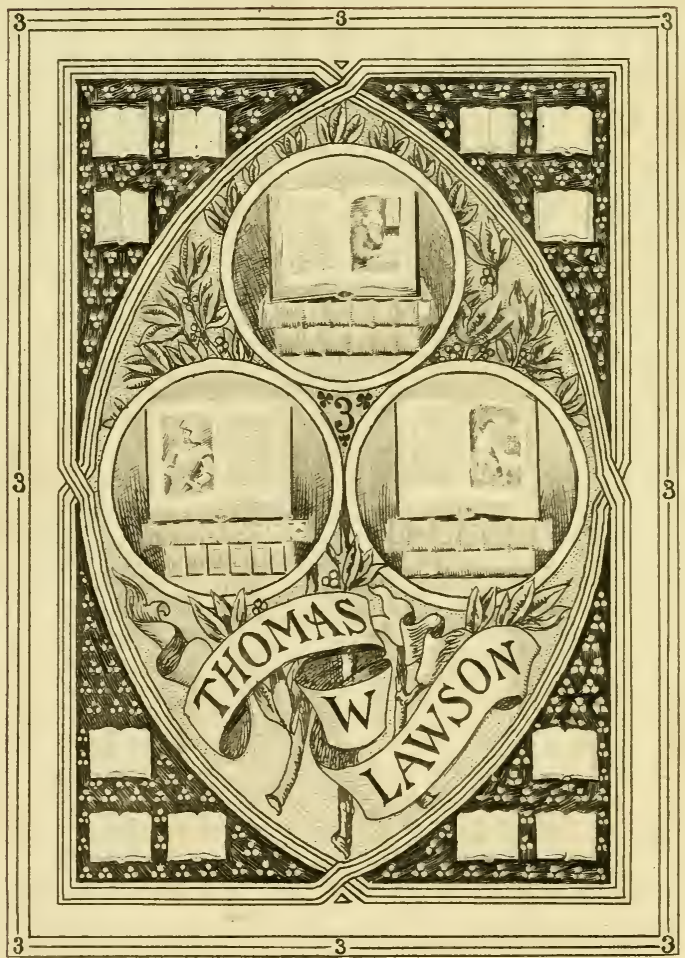


TUFTS UNIVERSITY LIBRARIES
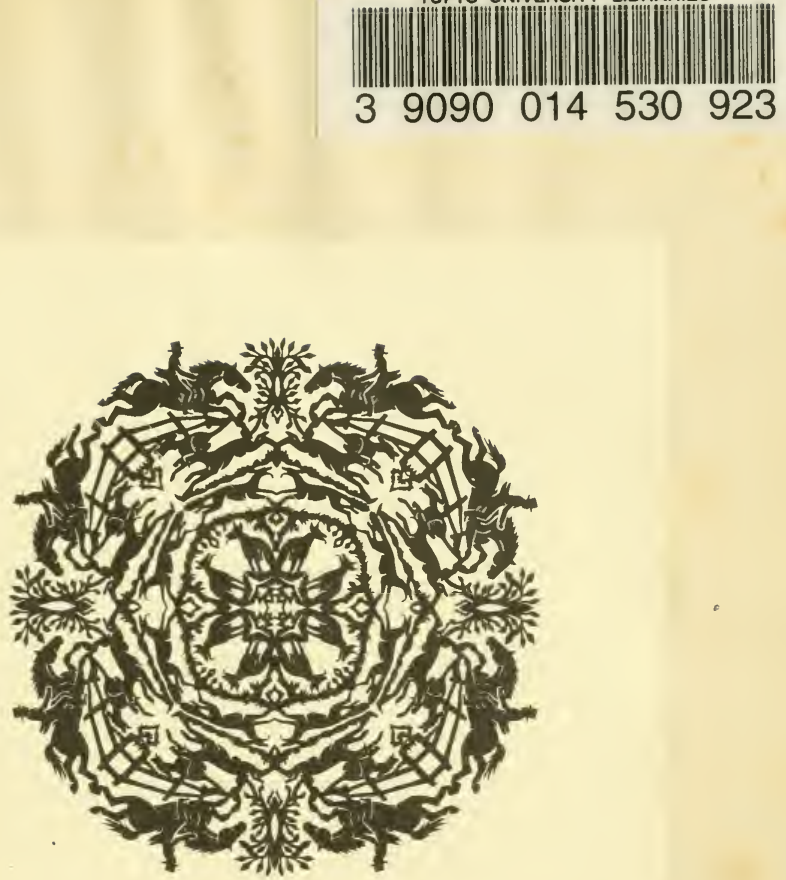

JOHN A.SEAVERNS 
Webster Family Libra' n f/eterinary Medicine Cumminar do lary Medicine at

Tufts Univ.

200 Westbor bad

North Grafton, MA 01536 




\section{The liutal Science Series}

Edited By L. H. BAILEY

THE FARMSTEAD 
Thes 


\section{THE FARMSTEAD}

THE MAKING OF THE RURAL HOME AND THE LAY-OUT OF THE FARM

BY

\section{ISAAC PHILLIPS ROBERTS}

Director of the College of Agriculture and Professor of Agriculture in Cornell University; author of "The Fertility of the Land"

$$
\text { SECOND EDITION }
$$

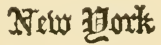

THE MACMILLAN COMPANY

LONDON : MACMILLAN \& CO., LTD.

1902 


\section{NA \\ 8201 \\ $\mathrm{Ric}$ \\ 1902}

soovenis

COPYRIGHT, 1900

\section{BY THE MACMILLAN COMPANY}

Set up and electrotyped January, 1900

Reprinted August, 1902 


\section{CONTENTS}

CHAPTER

PAGES

I. Rural Hoyes . . . . . . . . . . . . 1-11

II. The Faril as a Sotree of Incone . . . . . . 12-42

iII. Edecational Opportunity on the Farm . . . . . 43-53

IV. Selection and Purchase of Faris . . . . . 54-64

V. The Relation of the Farmer to the Lawyer .

(By Hon. DeForest Van Fleet) . 65-73

Vi. Locating the House . . . . . . . . . . . . 74-86

Vil. Planing Rural Buildings . . . . . . 87-131

Vili. Building the House - General Lay-out . . . . 132-157

Building the Foundations . . . . . . . 138

Wooden Houses - The Frame . . . . . . 142

iX. Bullding the Hotse, Concluded-Outsine Covering, Painting. . . . . . . . . 158-180

Veneered Houses . . . . . . . . . . 168

Old Houses . . . . . . . . . . . 170

Painting the House . . . . . . . 173

X. Inside Finish, Heating, and Ventilation . . . 181-192

Heating and Ventilation . . . . . 190

Xi. House Furnishing and Decoration. . . . .

. . . . (By Professor Mary Roberts Smith) . 193-203

XiI. Cleanliness and Sanitation-Water Stpply and

Setwage . (By Professor Mary Roberts Smith) . 204-223

Water Supply and Sewage . . . . . . 217 
CHAPTER

XIII. Household Administration, Economy, and ComFORT . ( By Professor Mary Roberts Smith) . 224-236 XIV. The Hone Yard . (By Professor L. H. Bailey) . 23i-248 XV. A Disclission of Barns . . . . . . . . 249-265 Location . . . . . . . . . . 255 Planning the Barn . . . . . . . . . 259 Water Supply . . . . . . . . . . 261

XVi. Building the Bakn - The Basenent . . . . 266-287 Excavation ............. 268 Walls ............... . . 271 Floors . . . . . . . . . . 277 Stalls . . . . . . . . . . . 280 Mangers and Ties . . . . . . . . . . 285

XVil. Bullding the Barn - The Superstructure . . 288-297 XVIII. Remodeling Old Barns . . . . . . . . 298-305 XIX. Outbulldixgs Axd Accessories . . . . . 306-320 Poultry Houses . . . . . . . . . 306 Piggeries . . . . . . . . . . . 311 The Silo. . . . . . . . . . . . 316

XX. Lighting Protection (By H. H. Torris, M.E.) . 321-335 Metal Roofs . . . . . . . . . . . 324 Protecting Wooden Roofs . . . . . . . 326

XXI. The Fields . . . . . . . . . . . . 336-345

Fences ........... . . . . 336

Orchards . . . . . . . . . . . 340

Farm Garden . . . . . . . . . . 341 


\section{THE FARMSTEAD}

\section{CHAPTER I}

\section{RURAL HOMES}

Man is made partly by heredity, partly by environment; both may be controlled and modified to a far greater extent than is generally supposed. In speaking of farm life, its disadvantages are frequently emphasized, while its possible advantages as an environment for the development of the finest quality of human nature are as often ignored or overlooked.

Nature, with her ever-varying form and color, beauty and symmetry, is forgotten in the city; the shady forest, the meadow brook, the waving fields, are unknown. There, instead, is incessant noise, the clang and clash of trade, towering and ugly buildings, skies darkened by the smoke of factories, children who never saw a tree or played elsewhere than upon a hard and filthy pavement; and worst of all is the nerve-destroying haste and unequal competition, wearing out 
body and soul. In rural life, however tame and lonely, the home is not merely a few square feet hedged in by brick walls, but the whole wide countryside: the barns, the fields, the woods, the orchards, the animals wild and domesticated, the outlook over hill and valleythese all constitute the farmer's home.

The manufacturer locates his factory in some by-street or suburb where land is cheap, and as far as possible from the residence part of the city; his home is far removed from these unsightly surroundings. But the farmer must live within a few hundred feet of his barns and outbuildings, and if these be ugly and dirty, the beauty and comfort of the home are sadly marred. If the farmer, then, has the whole landscape as a background for his home, he must on the other hand modify his immediate surroundings so as to overcome their almost inevitable unsightliness.

Besides the ever-present beauties of nature, country life has certain other advantages over the city: it is the place to develop the strong health-physique. The luxury of rich and populous communities tends to produce puny and enervated citizens; the excessive toil, bad air, limited space and scant food of the poor tend to degrade and destroy body and sonl; but the comfortable simplicity, space, air, sunlight and 
abmulant food of the open country give opportunity for the finest development of the human animal. It is true that even on the farm there are sometimes overwork and privation; but, at the worst, these cannot be so severe as in cities so long as the sum shines, the wind blows, and green things grow for the worker out of doors. Here the child may be born right and nourished by pure food and air. It is surrounded by animals whose life and motion become an incentive to action, and who become its companions without danger of moral contamination. The lamb, the calf, the colt, are far safer playmates than the city urchin precociously wise in evil ways.

Professor Amos G. Warner" says that "children reared in institutions are much below par because they lack the power of initiative." The farm child has an incessant, varied and unconscious training of the eye, the hand, and the mind. While he is developing strength, symmetry, courage, the mental is being coördinated with the physical. The hand is made to obey the will, while the fact that the handicraft is made useful lends charm and delight to the work. The city child must try to learn, by a course of manual training in some public school, what the country child picks up uncousciously in the natural process of play and work. 
After half a century, I look back to one of the happiest moments of my life, when I presented my mother with a dove-tailed wooden flower box, painted bright red. That flower box first taught me how to make wood take the form desired. While the flower box has long since rotted, the board-runner sled smashed, the water wheel broken, and the boat lies rotten in the bottom of the lake, the time spent upon them was not thrown away, for they gave me the inspiration and power to "boss" wood, and this power has served me well in many an emergency.

As knowledge begins to dominate the hand and train it to change the form and character of things, certain physical laws are discovered. If the sail is made too large or the boat too narrow, a cold bath is the result. If the sled rumners are too short and rough, the schoolmate arrives at the bottom of the hill first. No schoolmaster was needed, for when one of these natural laws was broken or ignored, the penalty followed quickly and with full force. So, in a thousand ways, the youth is taught respect for the laws which govern matter. All this leads the youth on the farm, if full play and direction are given, to investigate everything in sight, to discover that there are other than physical laws. The higher laws puzzle him greatly, 
give him much concern, lead to doubts, for they are too abstract and too far-reaching for his youthful comprehension. The physical laws have been found by experience to be ever true and stable, and the youth cannot but believe that moral and spiritual laws are equally so. This is the sheet anchor which holds him to belief in them, however imperfectly he may understand them. He is anxious to investigate, even to experiment along these lines, but is disappointed because the results cannot be set down in pounds or feet or units of energy. If here on the farm the mental and physical have been kept healthy and active, the moral and spiritual will develop as naturally as the fruit from the blossom. The development of spiritual fruit to high perfection is slow, because the power to think and reason correctly and abstractly comes only with age, experience and mental development.

But the greatest advantage of country life lies in the opportunity for the promotion of healthy family relations. Parents naturally find their chief happiness in the education and development of their children; and in time the children stimulate the parents. The sharing of common labors from babyhood up, the working together for common interests and ambition, which farm life especially entails, produce the most whole- 
some family relations. The most valuable part of any person's education is really in the home. To "help father and mother" becomes the keynote of a child's life, and unselfish, willing service is the first and last and best lesson of morality and religion. The pride in honest and capable ancestors, the natural and wholesome ambition for the future of the children, fill up a measure of contentment difficult to find elsewhere. In such a family there need be nothing to conceal; life takes on dignity in place of affectation, honesty instead of sham; it has simplicity, pure affections, fidelity. Artificial sex distinctions disappear; men and women may do that which is needful and hmman, the woman in the field, the man in the house, if desirable, sharing their common, healthful activities.

All this is very well, some will say, but how shall such a home be maintained on the income of the farm? "Farming doesn't pay." This statement is unverified, and, carrying on its face, as it does, a little truth, is misleading. Does farming pay? Does anything pay? What is pay? All depends upon how you value the currency in which the pay is recelved. Is "wisdom better than rubies?" Are the sayings of the wisest and best of men true? "Give me neither riches nor poverty. Get wisdom, get understanding, Take fast hold of instruction." 
A modern thinker, Professor L. H. Bailey, in the report of the Secretary of the Connecticut Board of Agriculture, 1s98, puts it in this wise: "But there is another cause of apprehension which I ought to mention, perhaps founded upon the probable tendencies of our suciological and economic conditions, especially as they apply to rural communities. There is a tendency towards a division of estates as population increases, and the profits of farming are often so small that educated tastes, it is thought, cannot be satisfied on the farm. There are those who believe that because of these two facts we are ourselves drifting towards an American peasantry. Let us take the second proposition first, - that the profits of farming are so small that educated tastes cannot be satisfied and gratified on the farm. Now I grant this to be true if the measure of the satisfaction of an educated taste is money; but I deny it most strenuously if the satisfaction of an elucated taste lies in a purer and better life. We must make this distinction very deep and broad, for it is a fundamental one. I believe we have made a mistake in teaching agriculture, during the last few years, by putting the emphasis on the money we make out of it. I do not believe that people are to become wealthy on the farm, as a few do in manufacturing; I should not hold out that hope to men. 
There are certain men here and there who have great executive ability, who see the strategic points and take advantage of them, who can make a success of farming the same as they would at the making of shoes, or harnesses, or buttons, or anything else. But as a general thing, the farmer should be taught that the farm is not the place to become wealthy. I do not believe it is. Certainly I should not go on the farm with that idea in view. But if I wanted to live a happy life, if I wanted to have at my command independence and the comforts of living, I do not know where I could better find them than on the farm; for those very things which appeal to an educated taste are the things which the farmer does not have to buy,-they are the things which are his already."

The wealthy few of the cities give voice to the thought that the farming classes in the United States are always on the verge of porerty, yet in the last century they have rescued from barbarism and solitude nearly all of the arable land of the two billion acres of which the United States are composed. More than four million five hundred thousand farm homes have been planted, valued at more than thirteen billion dollars. Much hue and cry has been raised of late about farm mortgages. If the facts were known, it is more than probable that 
the farmers, as a whole, have assets in mortgages, promissory notes and savings banks amply sufficient to liquidate all such outstanding obligations. Added to the real estate, the farmers own implements and machines valued at five hundred millions of dollars, and their live stock, upon ten thousand hills, numbers one hundred and seventy-five millions, valued at more than two billions of dollars, while the annual value of the farm products is between two and three billions of dollars. It should be remembered that these values are nominal, the true value being in most cases more than double these amounts. The farmers are not now in danger of becoming paupers. From the farms come more than half of the college students. At the present time it is probable that the income of the farmers exceeds three billion dollars annually. When it is considered that there is little or no direct outgo for rent of house, and that nearly three-fourths of the food is produced at home, and that these items are seldom taken into account in the statistics of income, it appears that the farmer's real income is much larger than is usually estimated in money. In other words, a five hundred dollar net income on the farm, under the conditions which now prevail, provides for a more comfortable living than does a thousand dollars in the city. 
But these results of the labors of the farmer as set forth in figures, tell but half the story, for nothing is said in these census reports of an empire redeemed, of the thousands upon thousands of miles of road constructed, of rivers spanned, of the school house by every roadside, or of the church spires which mark the progress of agriculture and civilization in countryside, in village and in hamlet. The census report does not give the number or value of the great men and noble women which the rural homes have produced, though they are the most valuable product of the farms. It says nothing about the perennial rural springs from which flow, in a never-ending stream, statesmen, divines, missionaries, teachers, students and business men. Although moie than half of these life-giving energies of the nation and civilization come directly from the rural homes, the census report gives no clue by which the value of these, the nation's wealth and power, can be ascertained.

Looking over all the trades and professions which are followed by civilized and barbarous peoples, none give opportunity for rearing the family under so nearly ideal conditions as does the profession of agriculture: none furnish such good conditions for rearing children and for developing them into strong, natural and useful men and women. Here, then, on 
these broad acres of America, muler the flag which we love, we are to help transform the rude surroundings of the pioneer and the slorenly homes of the careless into pure and beautiful nurseries of American citizenship. Having shown, in part, what a rural life has to offer to those who are trained to appreciate the beanties of nature and to obey her laws, and having shown that the average farmer always has an assured though modest income, and that the better farmers have an ample income for maintaining improved rural homes, the further discussion of how they may be made to minister to the natural longings for broader and more refined lives may be taken up. 


\section{CHAPTER II}

THE FARM AS A SOURCE OF INCOME

IF IT cannot be shown that the profession of agriculture offers as good opportunities for securing, with a fair degree of certainty, what all should prize, - a beautiful and comfortable home and a modest surplus, - then this little rolume will be for the most part useless and uncalled for, as the following chapters presuppose an income sufficient for maintaining a home, and for gratifying, in part at least, the simple, educated tastes of the better class of American farmers.

In "The Fertility of the Land" I attempted to set forth some fundamental principles which, if followed, should result in such increased incomes as to justify the present book. A comfortable home must be secured from the products of field and stable, with a reasonable expenditure of physical energy, or farming in its highest sense is a failure. In addition, farming must give fair opportunity for training and educating families, and for making provision for old age and unforeseen contingencies. 
In the previous chapter the annual income of the farmer has been set forth, and, approximately, the accumulated earnings of the rural population. Unfortunately, we are so shortsighted that the present-the dollar-blunts the appreciation of the higher and more enduring values which spring from well conducted farms. This being so, of necessity much stress must be laid on immediate benefits which flow from a well ordered farm life. While it is not proposed to write here of the details of farm management along the lines of greatest financial results, yet something must be said, at least in general, about the methods most likely to produce the necessary competence.

A fairly liberal income and financial reserve give, or should give, some leisure. Leisure gives opportunity for study and recreation, without which life becomes one ever-revolving round of work, and results in producing an automatic animal. If this is to be avoided, far-reaching plans must be laid, energy directed into its most efficient channels, and time and resources economized. All this implies training and education directed, primarily, along the lines which broaden and ennoble, and those of the occupation to be followed.

For centuries, the higher education has been in the direction of the humanities, while educa- 
tion along technical and non-professional lines, until recently, has been conspicuous by its absence. Prior to the present century, what provision was made for coördinating the hands and intellects of the industrial classes? None at all. Is it any wonder, then, that the farmer and mechanic, until recently, received but meager rewards for their efforts?

All this is now changed. Already the industrial classes are enabled to secure far more of the necessaries and luxuries of life for a given period of work than could their ancestors. In every state and territory one or more colleges have been equipped and endowed to teach, among other things, "such branches of learning as are related to agriculture and the mechanic arts, mactical education of the industrial classes in the several pursuits and professions of life." In addition to this provision, Congress gives to each state and territory $\$ 15,000$ annually for conducting experiments and investigations in agriculture. In 1890 the Federal government supplemented the benefactions of 1862 by appropriating annually $\$ 15,000$ to each of the Land Grant colleges; this sum has now been increased and finally fixed at $\$ 25,000$, for the purpose of strengthening the departments of agriculture and mechanic arts. Most, if not 
all, of the states have made additional appropriations for agriculture, in some cases very liberal ones. At first, there was a strong prejudice against these colleges devoted to the improvement of the industries and those engaged in them, but this has nearly disappeared.

A broader view of education now prevails than formerly. The modern colleges and universities think it not undignified to offer other than four year courses of study preceded by difficult entrance requirements. Many courses of from six weeks to one or two years are now open to those who prize knowledge above a diploma. Most of these courses are given at such seasons of the year as best suit the pupils. In America all doors which lead to knowledge have at last been opened, and all earnest students may enter and find teachers awaiting them. The effect of the recent changes in college courses has been most marked and beneficial. Many of the colleges have, as far as possible, adopted the words of the founder of Cornell University: "I would found an institution where any person can find instruction in any study."

The following data show the incomes of the United States Land Grant colleges for the year ending June 30, 1897. The table is condensed from one recently published by the United States Department of Agriculture : 


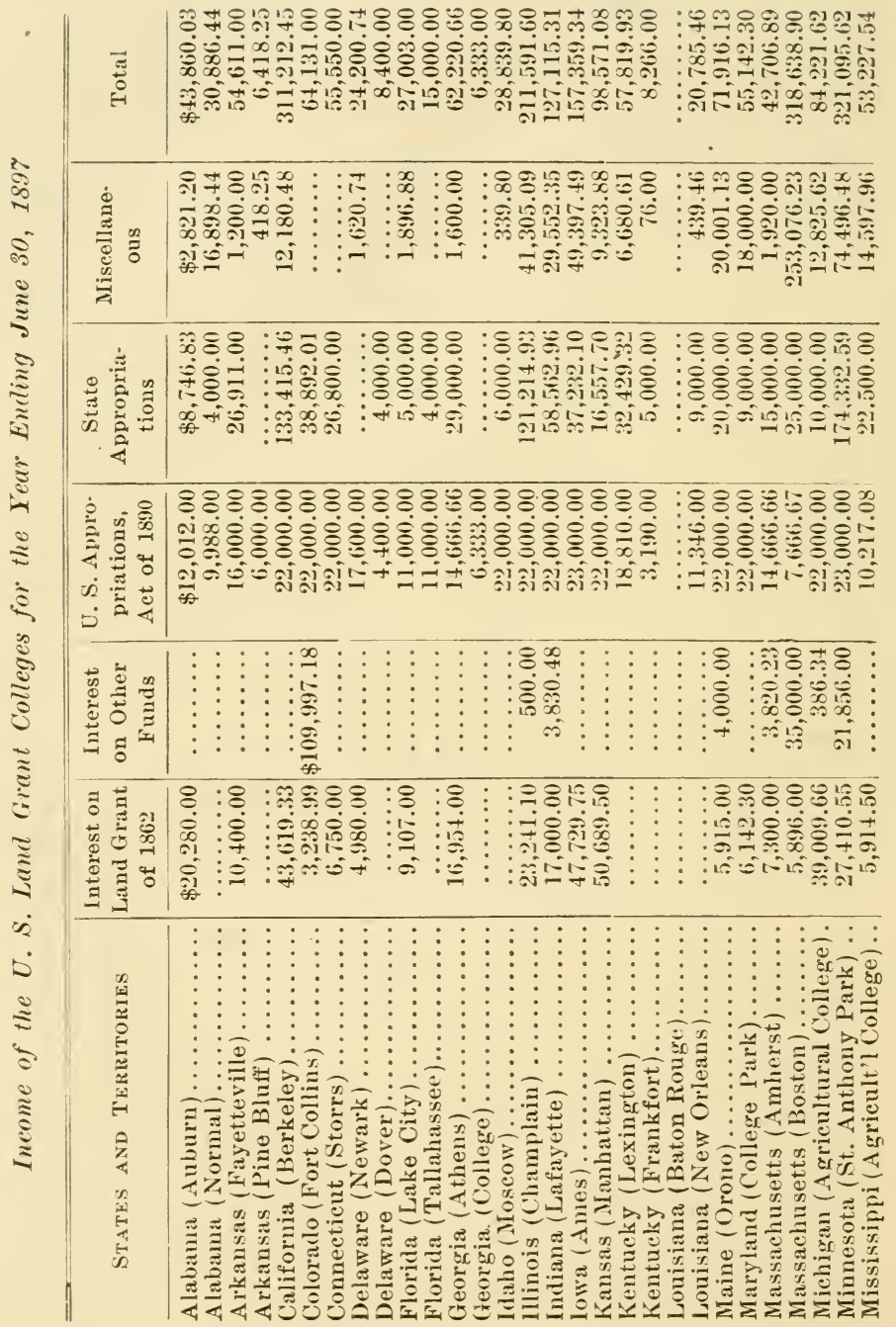




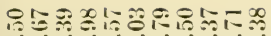

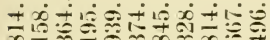

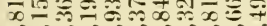

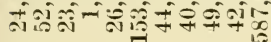

:

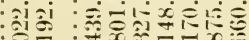
is
: $\hat{\theta} 190 \div$ :

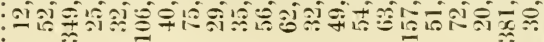

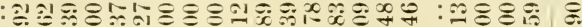

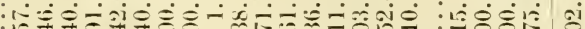
: $\therefore 15 x-x=0$
8ㄴ. த்

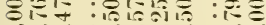

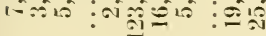

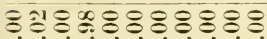

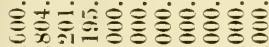

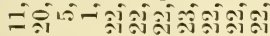

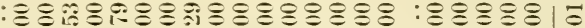
: : (1)

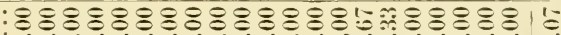
:

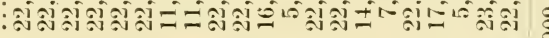

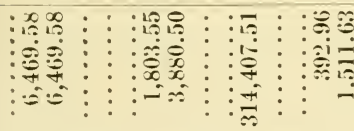

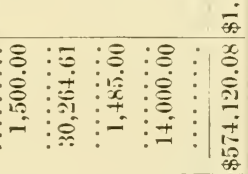

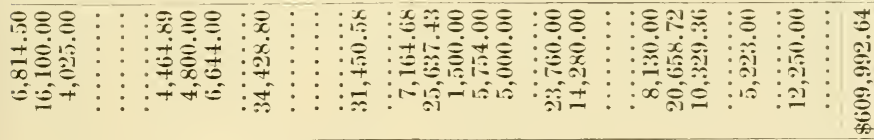

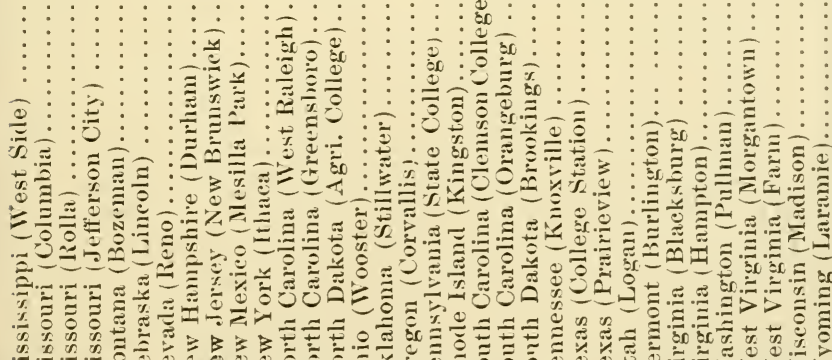
药 
It has been thought strange that the farmers did not more quickly see and appreciate the valuable opportunities offered to their children. But why should they at once appreciate and value the princely provisions which were being made for them? With no opportunity for education along the lines of their profession, following a more or less despised calling, from being the butt and jest of those who had had educational advantages from time immemorial, how could they at once understand the value and far-reaching effects of the new order of things? Then, too, these liberal provisions were made somewhat in advance of the times. The pioneer must first redeem the land from the wilderness, fight the physical battles and endure the hardships of a new country. As soon as these primitive conditions passed away, the farmers made an effort to bring their profession up to a high intellectual plane and make it a delightful and honorable calling. The evolution from the primitive to the complex, from the age of toil to the age of thought, from excessive muscular effort to a more intelligent direction of energy, from the narrow and prejudiced to the broad and liberal, from the coarse and ugly to the refined and beautiful, is proceeding rapidly, and is in part realized. What happier task than to give direction and help, sympathy and en- 
couragement to these new-born desires! The part which the youths on the farm are taking in this evolution leads naturally to a higher intellectual plane, and hence to a more rational understanding and fuller comprehension of what the rural home should be. This desire to gratify the love for the true and beautiful, which has been growing up by reason of the better education, leads directly to the securing of an income sufficiently large to gratify the more refined and newly acquired tastes.

Taking the rural population as we find it, with added wants and new aspirations, and with a somewhat better understanding of the value of a more extended culture, it will be seen that a more rational system of agriculture, a more economic expenditure of energy, and a clearer comprehension of the highest and most economical use of money must be secured if the objects sought are attained. To secure the results desired, it must be shown how a competence can be secured without excessive toil, how the results of work may be put to the best uses, and lastly, but not least, it must be shown what is really valuable, what real, what substantial, what polite, what beautiful, what worthy of intelligent Americans. On the other hand, rulgar display must be shown to be vulgar, shorly must be unmasked, the effect of aping the un- 
cultured rich set forth, and that which is unreal and that which goes for naught but vanity displayed under their true colors, - that comparisons may be made, and that truer conceptions of life, its duties and obligations, may be secured.

How may a competence be obtained? Briefly, by securing a knowledge of the laws which govern the business or undertaking entered into, and by conducting the business or undertaking in obedience to the modes of action or laws which apply to the specific case in hand. That are some of the dominant laws which should govern the farmer and farm practices? The farmer should specialize along those lines for which his taste and training, in part at least, fit him. To be more specific: A farmer will show you his potato patch with pricle, but not a word will be said abont his work animals and their offspring, which look like Barnum's woolly horse. Then the first principle of agriculture is, follow up successes. In this case, the man has land and skill in potato culture which should lead him directly to success. Why not each year increase the output of potatoes, and let some horseman breed the horses? I have no ear or taste for music; why should I spend time in thrumming a piano and in making the life of my neighbors miserable? I love a bird and am interested in all its ways, its beauty and its life. 
Why not study the birds, and let them make the music?

Much of life's energy is spent in trying to adjust square pegs to round holes and round pegs to square holes, and life may be spent before the adjustment is complete. Modern civilization tends to specialization. Men vary as widely as do the stars. There is a place for everyone and some one to fill the place, if this great mass of unlike units can only be sorted and fitted into the complex problem of civilization.

The first question, and the question which should be repeated often is, What am I good for; what branch or branches of agriculture will give me the greatest pleasure and profit? Having answered this question, pursue the work through all discouragements to a successful issue. It is possible you have no capacity for farm life, and, since you cannot buy a capacity, better go directly to town and there fit yourself into your environment. I have known men to toil many years on a farm, and near the close of life to be driven to town by the sheriff. There they made not only a living, but secured a modest competence in conducting some little one-horse business, the profits or losses of which could be counted up every night. The farm, with all its complexities, with its profits and losses a year or five years in the future, was too large and 
far-reaching for their narrow understandings. All are not so fortunate. Some remind us of the Quaker's dog which he sold to his friend and recommended as a good coon dog. The dog proved to be a failure and was returned to the seller, who said, "I am much surprised. Thee believes that nothing was created in vain, does thee not, Ephraim?" "Most certainly I believe that the Creator made all things for some beneficent purpose." "I, too, believe this, and I had tried that $\mathrm{dog}$ for everything else under the heavens but coons, so I was certain he must be a good coon dog."

A competency is always in sight in this country for those who do well those things which are suited to their tastes and training. A competence may be secured by following those branches of farming which require the minimum of labor and the maximum of skill and training. My friend of Westfield, Mr. G. Schoenfeld, from Germany, has six acres of land, a part of which is covered with glass. He did that terrible thing, - ran in debt for the full purchase price of the land. It and the valuable improvements upon it are now paid for. His modest home is ralued at $\$ 6,000$. While paying for it a large family has been raised and educated, the eldest boy entering Annapolis Naval Academy with a high standing. It is possible that this 
son will one day be acknowledged as the intellectual and social equal of the aristocracy of Germany should he ever visit the fatherland of his parents. But why this long account of a not infrequent occurrence? To show how it was done: This German, though untrained, succeeded from the first in producing superior carnations. He followed up his successes, and sold the product of brains instead of the fertility of his little farm. Mr. Schoenfeld sold in Buffalo during one year-October 1, 1896, to September 30,1897 - carnations $(80,946$ flowers $)$ for the net sum, over commissions, of $\$ 719.08$. The amount of plant-food removed by the 80,946 carnations was as follows:

Nitrogen Phosphoric acid Potash

5 lbs. 4 ozs. 2 lbs. 3 ozs. $10 \mathrm{lbs} .8$ ozs. (valued at $\$ 1.32$ )

The table below shows the amount of plantfood removed by 8.56 bushels of wheat, being the amount which, at 84 cents per bushel (the average price of wheat for the last ten years in central New York), would bring \$719.08, the amount received for the carnations.

$\begin{array}{lccc}\text { Nitrogen } & \text { Phosphoric acid } & \text { Potash } & \\ 904 \mathrm{lbs} . & 437 \mathrm{lbs} & 298 \mathrm{lbs} . & \text { (valued at } \$ 158.34 \text { ) }\end{array}$

In addition, 20,000 flowers used in making flower displays for weddings, and the like, were 
sold at retail, by the dozen, for $\$ 450.80$. The net returns for flower's sold during the fiscal year ending September 30, 1897, amounted to $\$ 1,169.88$. The expenses, including taxes, insurance and 10 per cent on the capital, were $\$ 790.67$. This includes the cost of raising 12,000 plants, about 6,000 of which netter $\$ 263.24$. In round numbers, then, the net income from the one leading industry-flowers after paying 10 per cent on invested capital, coal, commission and workmen's bills, wa $\$ 642.45$, with an additional prospective income from the 6,000 plants which remained unsold.

When I last risited this gentleman, he informed me that he had all the land he wanted. Since that time he has purchased eight acres arjoining, has made some improvements upon the land, and now values it at \$2,000. He stated incidentally that the reason he made his purchase was that the land was in the market, and he wanted control of it that he might choose his neighbor. The land, he says, is now in the market, although it paid ? per cent, clear of all expenses, on a valuation of $\$ 2,000$. The question is often discussed as to how much land is necessary to secure a competence. Here we find that six acres suffices. A large family has been fed chiefly from the products of the orchards, rineyard and garden, and the children 
are receiving a practical and, in some cases, a liberal eduration. All this has been accomplished because the man quickly learned the value of scientific agriculture and was wise enough to follow up his successes.

Not only follow up success, but learn to do the difficult things; there will always be a throng seeking to do the easy things, - things which require the maximum of muscle and the minimum of brains. Why do such multitudes seek this hard, easy work? Because they will not consent to endure the toil, shall I say, of acquiring the power to think deeply, accurately and effectively. Some of our sympathy is thrown away upon these muscular workers. Their desires are few, their wants simple, their appetites good, and their sleep peaceful. Let us show them the way to a higher life, open the doors to those who choose to enter, and fret not because all will not enter in.

"Some are and must be greater than the rest, More rich, more wise ; hut who infers from hence That such are happier, shorks all rommon sense."

The man who fells the trees in the woods may receive 15 cents per hour; the man who controls the carriage of the great sawmill and decirles on the instant what shape and dimensions the lumber shall take may receive 25 cents 
per hour for simply moving a little lever; a third man causes a piece of the wood to take on the forms of beauty for the great staircase, and may receive 50 cents per hour; the fourth furnishes the design for this beautiful staircase, and may receive $\$ 1$ an hour. The man who does the so-called "hard" work receives the least pay. Why? Because it is the least difficult. This difference of remuneration holds good on the farm. MIushrooms sell for 50 cents per pound; maize for one-half cent per pound. Why? Because anybody, even a squaw, can raise maize, but only a specially skilled gardener can succeed in mushroom culture. Hothouse lambs bring from $\$ 6$ to $\$ 10$ when two months old; a poorly bred sheep at two years of age may bring from $\$ 2$ to $\$ 4$. Why? The breeding and feeding of the one is easy; of the other difficult.

In 1897 the raising of potatoes was difficult. The blights, the bugs and the beetles were present in full force. Good potatoes in the middle and eastern states rose to 65 cents per bushel wholesale. The man who watched and fought intelligently secured 300 bushels per acre and a ready market; the careless man and the man who should have been raising horses or chickens secured 30 bushels per acre and a slow market. Why? Because unusual difficulties were pres- 
ent, and the man who was able to cope with them drew the prize of $\$ 195$ per acre for his potatoes. This successful potato raiser the previous year secured more than 300 bushels per acre, and sold them for 25 cents per bushel, but eren at this low price they brought more than $\$ 7.5$ per acre. If from 200 to 300 per cent profit can be secured and the limit of profit not reached by raising one of the most common products of the farm, what possibilities loom up for securing a competence from those products which require greater skill and knowledge than the raising of potatoes?

Consider the crops which are supposed to give promise of securing little or no profits at the present low prices, as wheat, maize, hay and oats. One man, on land naturally below the average, has secured during the last fifteen years an average of nearly 35 bushels of wheat, and in a few cases 40 bushels per acre. The average yield for the whole United States in 1889 was a shade less than 14 bushels per acre. During the same year the average yield of oats was 28.57 bushels per acre, and hay, including such other crops as are used for forage, averaged 1.26 tons per acre. Good farmers secure 40 to 50 bushels of oats, and 2 to $2 \frac{1}{2}$ tous of hay, and in propitious years 50 to 60 bushels of oats and 3 tons of hay per acre. (Compare Figs. 1 and 2.) These 
latter yields always show large profits and lead to a competency, while the average yield usually gives no profit. If the average yield gives only a bare subsistence, what must be the condition of those who secure much less than the average? If one man raises 35 bushels of wheat, five

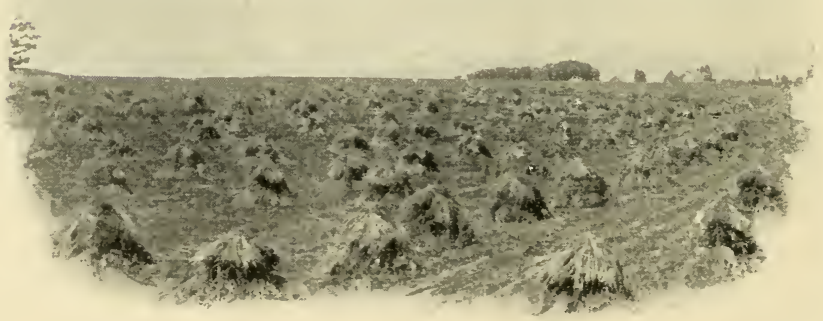

Fig. 1. Thirty-five-hushel wheat field (Cornell University).

other men must each raise 10 bushels to secure an average vield of 14 bushels per acre. Some entire states - as, for instance, Mississippi, North Carolina and Tennessee, - have an average of 6, 6 and 9 bushels, respectively, per acre. What is the remedy? Stop raising wheat, and raise something better adapted to soil and climate, or 
go to town and sell peanuts. Some of these men who utterly fail to comprehend the laws of wheat culture may be good " coon dogs," after all.

It will be said that if the yield per acre be doubled, the market will be so flooded that no one

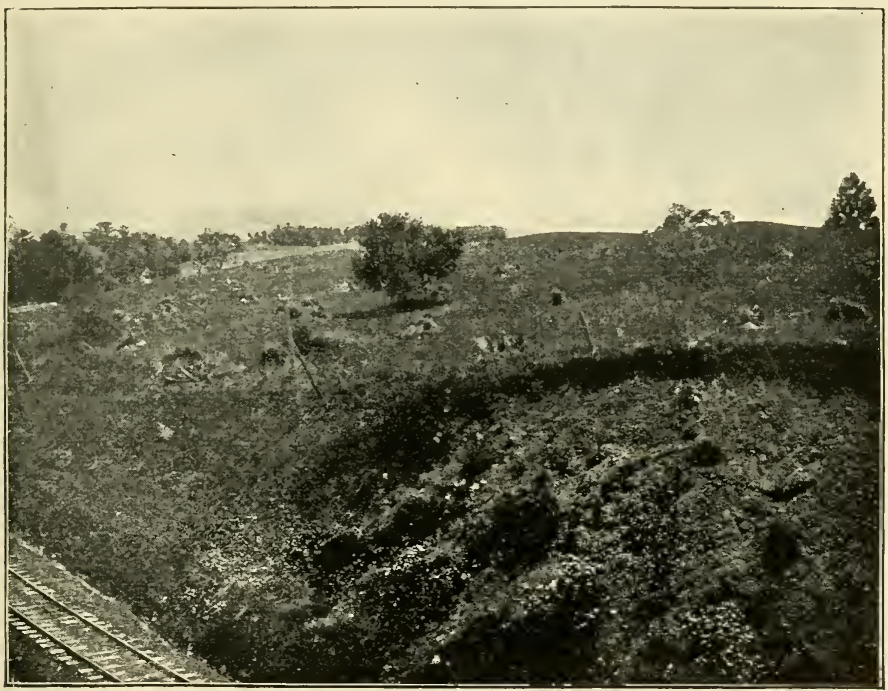

Fig. 2. Eight-bushel wheat tield, on a farm adjoining that shown in Fig. 1.

will receive profits. This is the old scarecrow. No farmer can control the prices of his product. The law of supply and demand is inexorable. What he may do is to improve quality, diminish cost, reduce area, find the best market and the products most sought, and increase the 
production from a given area. If he raises the yield from 20 to 35 bushels, while the yield of his neighbor remains at 10 bushels and prices remain low, we shall soon see a fine illustration of "the survival of the fittest." The 35 bushels will yield a fair remuneration for the work expended in production when prices are at the lowest. When they are high the profits are 200 to 300 per cent. Wheat, for the last ten years, has areraged 84 cents per bushel in June in central New York. Allow $\$ 3$ for the straw of the lower yield, and if the wheat was sold at the average price, the total income per acre would be $\$ 11.40$. For the straw of the larger yield allow $\$ 6$, which, added to the wheat at the average price, would give a gross income per acre of $\$ 35.40$.

The cost of raising and marketing an acre of wheat, including \$.j for rental of land and \$2 for fertilizers, may be set down at from $\$ 15$ to $\$ 20$ in New York. If the most successful compels the less successful farmer to stop raising wheat at a loss, what will the latter do with his land? Better give it away than lose by farming it. Better abandon the farm and go to town and set up a second-hand clothing store. There is always at least a small profit in that business.

In central Now York a large herd of dairy cows was tested, and the owner of the herd 
was informed that about one-fourth of his cows were quite profitable, one-half paid their board bill and a little more, and one-fourth were kept at a considerable loss. He was advised to dispose of the unprofitable cows. His answer was, "But what will I do for cows?"

Then, to secure a competence, the crops and the land which uniformly produce loss must be abandoned. How it worries the city penny-aliner and how it rejoices the successful farmer to see land thrown out of cultivation - "abandoned." To me nothing is so encouraging in agriculture as this lately acquired knowledge which reveals the fact that vast areas have been cleared and brought under cultivation which should have been left undisturbed, except to harvest the mature trees and protect the young plants from ravages of fire and cattle. As the blackberry bushes, year by year, creep down the steep hillsides and over the rock-covered fields, one rejoices at the pioneer work these modest, hardy, tap-rooted plants are accomplishing. How wisely and well they fit the soil for a higher and more noble class of plants, and how surely in time they cover the shame and nakedness of mother earth!

The rural population has made many serious mistakes, toiling to reclaim land which was not worth reclaiming, not worthy of an intelligent 
farmer. But how could they know better? Not one college of forestry in all this great land up to 1898, and as yet but one in its infancy! Until the last generation not a single school of agriculture, scarcely a book obtainable which might give direct help to the rural American boy and girl! Therefore, the farmer should not be blamed for the wasteful and unscientific treatment of forest and field. All this leads to the conclusion that to secure a competence, lands of high and varied agricultural capabilities, lands wortly of an intelligent American, should be selected upon which to build and maintain rural homes.

Quantity of farm products we have in abundance; better quality is what is wanted, since quality may improve prices and widen markets. To assist in securing a competence some specialization is advisable. Sometimes this has been carried so far as to work serions disaster. Many farms in western New York have been almost exclusively devoted to the raising of grapes, which, when abundant or moderately so, sold at ruinous prices. It is noticed that where only an eighth or a fourth of the farm was devoted to vines, the yield was not only proportionately larger but the quality better than where nearly all the land was used as a rineyard. Wherever diversified agriculture was car- 
ried on to a limited extent and plantations were restricted, the low price of grapes made no serious inroads on the income. Where all the land was given up to grapes, work was intermittent, the farmer being overtasked at one season of the year and idle at another. The demoralizing effect on the farmers and their families of this army of unrestrained youths and loungers of the city, which, for a brief period, swarms in the districts devoted to specialized crops, as grapes, berries and hops, is marked.

The baleful result of raising a single or few products in extended districts may be seen in California and the great wheat districts of the northwest. In such localities there is little or no true home life, with its duties and restraints; men and boys are herded together like cattle, sleep where they may, and subsist as best they can. The work is hard, and from sun to sun for two or three months, when it abruptly ceases, and the workmen are left to find employment as best they may, or adopt the life and habits of the professional tramp. It is difficult to name anything more demoralizing to men, and especially to boys, than intermittent labor; and the higher the wages paid and the shorter the period of service, the more demoralizing the effect. If there were no other reason for practicing a somewhat diversified agriculture, the weltare of the 
workman and his family should form a sufficient one. Happily, many large and demoralizing wheat ranches are being divided into small farms, upon which are being reared the rooftree, children, fruits and flowers.

To secure a competence, no more activities should be entered into than can be prosecuted with vigor and at a profit. On the other hand, too few activities tend to stagnation and degeneration. Mental power, like many other things, increases with legitimate use and diminishes with disuse. The farmer who simply raises and sells maize is often poor in pocket and deficient in understanding. The college graduate who attempts but a few easy things seldom becomes a ripe scholar.

To secure a competence, the petty outgoes should be met by weekly receipts from petty products. I have known so many farmers to succeed by specializing moderately along one $\mathrm{ol}^{\circ}$ two lines, while holding on to diversified agriculture, in part at least, that I am tempted to give a single illustration as a sample of thousands which have come under my notice.

A Scotchman and his family of four little children landed in northern Indiana with three to four hundred dollars; to this was added as much more by day labor. A farm of about one hundred and fifty acres was purchased, one hun- 
dred acres of which were adapted to wheat, corn and clover. Thirty acres were marshy pasture land; the balance, timber. Wheat was selected as the great income crop, which was supplemented by the sale of one to three horses yearly. The butter from a dozen cows, the chickens, ducks, and their eggs, were taken to the city once each week. The result was that at the end of the year there were no debts of subsistence to be paid. This left all the money received for the wheat and horses to be applied towards liquidating the mortgage. In a few years a large, comfortable house was built. This was followed by the purchase of another farm, and still another, until each child was provided with a home and facilities for securing a modest income. This shrewd Scotchman succeeded because he neglected neither little nor great things.

With what pride the writer, in 1863 , deposited $\$ 1,700$ in bank, the product of a single wool crop! - and the little farm of one hundred and twenty acres was not all devoted to wool-raising. If a young man can secure a loving, helpful wife, four good cows and enough land to produce feed for them, with room left for an ample garden, a berry patch and a small orchard, he may consider himself rich, and if he be able and intelligent he will soon have a competence. 
The farmer, of necessity, goes to the city or village once each week for supplies which cannot well be produced on the farm. He should return, if possible, with more money than he had when he left home. It is not the big mortgage which was given for part of the purchase price of the farm which should make him unhappy, but the steadily increasing little charges accumulating on the tradesmen's ledgers until this "honest" farmer dreads to meet a score of his town acquaintances.

The farmer who, from his well-painted covered democrat wagon, sells the product of his skill and labor looks to me quite as dignified as does the merchant who sells nails and codfish, turpentine and bobbins, patent medicines and jews'-harps, none of which represents his own skill or labor.

Farming will never be carried on in America by trusts or syndicates. A combine can run fifty nail factories or breweries, but not fifty farms, at a profit, because farming is too difficult, requires too close supervision and frequent change of details and combinations, and new plans to meet the ever-changing conditions of climate and soil. The ronditions which surromed agrierulture in Annerica put a quietus forever on "bonanza farmins"," and tend to the rearing of ideal homes and the accumulation of 
modest incomes. Mining-farming on virgin, fertile, mobstructed areas can be successfully prosecuted only for a time.

"The Red river valley native soils contain from .35 to .40 of nitrogen, while the soils which have been under cultivation (in wheat) for twelve to fifteen years contain from .2 to .3 of a per cent." * Another important point: When humus is taken out of the native soil as above, only .02 of a per cent of the phosphoric acid is soluble by ordinary chemical methods, while in the native soil three or four times as much phosphoric acid is soluble and is associated with the humus. Allowing that an acre of soil one foot deep weighs 1,800 tons, the native soil would contain from 12,600 to 14,400 pounds of nitrogen per acre, while the cultivated soil would contain from 7,200 to 10,800 pounds per acre. If the average amount of nitrogen in native soils $(13,500$ pounds per acre), and the average in the soil after it had been cropped twelve to fifteen years $(9,000$ pounds per acre), are compared, it will be seen that the soil has lost 4,500 pounds of nitrogen per acre, or more than one-third (probably one-half) of the nitrogen which could well be made available, and this in less than a quarter of a century.

*Henry Snyder, Bulls. 30, 44, Minn. Exp. Sta. See "Fertility of the Land," p. 256. 
Fifteen crops of wheat of 25 bushels per acre require 433 pounds of nitrogen, or onetenth of the amount which the soil lost during the years of cropping. This soil, under "bonanza farming," has lost outright nitrogen sufficient for 155 crops, each requiring as much nitrogen as does a crop of 25 bushels of wheat per acre. When the amount wasted on a single acre is multiplied by the acres of the vast, fertile wheat plains of the west, where "bonanza farming" is carried on, the loss of nitrogen to our country is seen to be so great as to appal the thoughtful man who looks forward to the generations who will want this element in the not distant future. Happily, this "bonanza farming" has its own cure. When mining-farming reduces the yield so that profits vanish, then these great farms will be cut up into modest-sized ones, true homes will rise, intermittent labor and the tramp harvesthand will disappear, and the last and only condition which tends to produce an uninstructed peasant class will cease to exist.

The other great "bonanza" industry which still remains and which affects agriculture, and the land directly, is lumbering. This, like "bonanza" wheat farming, may be classed as a mining industry, carried on at the surface instear of in the bowels of the earth. Without rational 
direction, restraint or control, this agricultural mining goes on until the sources from which the profits are drawn are so depleted as to be no longer profitable. There is no home or competency for the farm boys in the lumber camp or on the great wheat farm. Here the rule is to take all and return nothing. After the ax and the binder, comes the fire to complete the wanton destruction. The shade-giving' and moisture-conserving brush, stubble and straw, and all living plants, are destroyed, and nothing but the mineral matter, unmixed with surface humus, remains. A blackened waste, devoid of animal or vegetable life, is left behind. No homes can be reared here, no competence secured until nature, assisted by man in the coming years, slowly restores the corering and productivity of the soil. This unwise treatment of the land must soon come to an end; then the hardy home-builder will have opportunity to repair, by more rational methods, some of the wanton and unnecessary waste.

Is it too much to hope that before the close of another decade every state and territory will have a school of forestry, and that all national forest domains will have been brought under rational supervision and control? The future home-builders will need them, and the present owners of homes have a right to a share of 
the benefits which flow from intelligently managed forest preserves. It is not enough to show that intelligent farming is highly remunerative at the present time; provision must be made by which the children and the children's children, for all generations, may have opportunity for securing a competence from rural pursuits.

Can a competence and a comfortable home be secured by the renter? If not, why not? Shall the farmer put his little capital into a home and run in debt for supplies and necessary equipment; or had he better rent, and start even? This depends to a large extent upon the individual. A successful country life does not depend upon owning the land in fee simple. Here is a picture of what may be called "a country gentleman" (Fig. 3). He, his father and his grandfather, all have been renters of the same farm. He has a competence and an assured income. This hue and "ry about renting has no terrors for those who have been renters and have found that this is often the most satisfactory way to start when capital is limiter. The merchant of limited means invariably rents the building in which he does business, because it is safer and usually more economical to rent than to purchase the business block. 
In an old eity of 12,000 inhabitants, it was found that it per cent of the business was carried on in rented rooms. The trouble in renting farms in the United States lies chiefly in

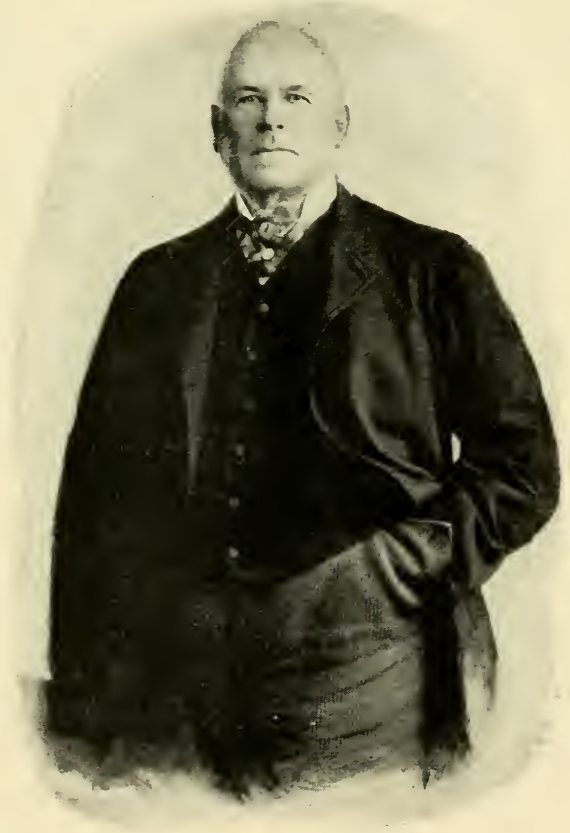

Fig. 3. A farmer and a renter.

the fact that there are no well digested laws or old custons which help to guide the renter and rentee. A few simple laws would provide for adjusting the value of betterments remored from 
or put upon the farm at any time. Long leases, with inducements to long occupancy, would give the rentee a permanent occupier. The renter has quite as good a chance of finally securing a home in fee simple as has the man who purchases and mortgages heavily. The possession of a valuable farm and an assured income, especially in a new country, is often most surely and easily secured by renting for a series of years. Good farming pays liberal profits even on rented land. If there is failure, it is the man and not the occupation which causes it. The fault will not be "in the moon," but in ourselves if we fail or become underlings. 


\section{CHAPTER III}

EDCCATIONAL OPPORTUYITY ON THE FARM

More and more we are coming to believe that the rural district schools offer but few opportunities for educating the farmers' children. Various schemes have been recommended for providing better and more convenient elucational facilities. One proposition is first to improve the principal highways. This, it is thought, will make it possible to run 'buses or' carriages twice daily to transport the children to and from some centrally located graded school. Such schemes are usually proposed by some one who has seldom seen a country school-house and who is totally unacquainted with the conditions which prevail in rural communities.

Admitting, for the sake of comparison, that teacher and pupil in the country are not so far advanced in book-lore as they are in the city, how does it happen that the country youths are able to maintain themselves on an educational level with the pupils of the graded schools when they meet them in the academy and college? Is it not quite possible that the wide opportunities 
enjoyed by the rountry routh for becoming acpuainted with natural objects of use and beanty are a full offset, so far as training is concerned, for the more systematic instruction given in the eity schools?

I can but look with some degree of solicitude on the effect on civilization and on the home, of palatial hotels, and great school buildings, filled with heterogeneous masses of children, in which love, solicitude and sacrifices, each for all, have little opportunity for growth and development. The family seems to be the sacred unit of civilization and morality. A full and sufficient reason must be given for massing men, much more children, in a single great structure, thereby destroying the quiet and breaking the sacred ties of the home. What good reasons can be offered for massing ehildren between the ages of six and twelve in an uncomfortable schoolroom? Children do not study; they learn little except when they read the lesson in the immediate presence of the teacher who is able to amplify and explain the lesson in hand. Sending these little ones to school is a relic of the primeral days, when, by reason of large families, lack of training and excessive toil of the parents, there was no other way but to make nursery maids of the school-teachers.

I have a vivid recollection of those early 
days when I was crowded into a $16 \times 20$ schoolhouse, with two score other bounding, mischievous urchins, all seated on the hard side of unbacked, long-legged slab benches, which left our bare legs, for which the flies had a liking, to dangle between heaven and earth. True, all this has now been improved, and good and appropriate seats are usually provided, but this only ameliorates the conditions; it does not cure them. If the parents who have lost something of their first love for their children, or who are too lazy or careless or ignorant to teach them, will go to these patent-seated school-rooms and sit for five mortal hours on one of these hard, wooden, uncushioned seats, they will no longer place their tender children in these modernized stocks. You who no longer have the hot blood and restless nervous energy of youth make long faces and complain bitterly from your well cushioned pew, if the over-earnest pastor prolongs his sermon ten minutes beyond the customary time. It may be said that many, nevertheless, secured a primary education under these unfavorable conditions. But I did not; I received it at my mother's knee in the old kitchen, some of it before daylight. About all I got in that old school-house were kicks and cuffs from boys who were older and stronger than I, and round shoulders from sitting through many 
weary hours on backless benches, and blistered hands in punishment for my unrestrained interest in things in general, and in my schoolmates in particular.

But what has all this to do with the opportunities which a farm life gives for education? It is to emphasize the need of more home training, more personal attention by the parents, and a more natural and rational education of those whom it has been our responsibility to bring into existence, and upon whose shoulders will rest the weal or woe of our country. In these rural homes, children should be reared and educated until they have reached the point beyond which their parents or the older children cannot carry them. The child, when only two or three years old, begins to learn handicraft, performs some little helpful act for another; it is being tanght to work. As it becomes more mature it is to do useful things; but who thinks of keeping the child of eight to ten years of age at continuous work for five or six hours daily? Why not carry on the child's mental education along these natural lines in the same manner as it receives its primary technical education ?

I am almost persuaded that the farmers' children would be better off if the old red school-house on the dusty, treeless four comers was abandoned, and the responsibility for the 
education of the children up to twelve or fourteen years of age was thrown upon the parents. As it is, the parents who have received a fairly good primary education become rusty and illiterate simply from non-use of the education which they had when they left the schools. If the unexcelled opportunities which rural life offers for securing a primary education were only utilized, there would be fewer country youths hating even the sight of that red school-house which has received such honorable mention. It has been glorified in every Fourth of July oration, but it still remains not only unevolutionized but even degenerated.

If you ever imagined that the best provision has been made for teaching the little ones, spend a day in one of these school-houses. Take some book with you that is as abstract and useless to you as the children believe their books to be to them, and make the attempt to memorize a single page, or essay to write a composition on "The Immortality of the Soul," or on "The Wisdom of Annexing the South Sea Islands." Meantime, classes are reciting in falsetto voices; the teacher is giving many admonitions and making dire threats; a festive bumblebee has found its way through the open window and makes as much commotion among the timid girls as a mouse at a tea-party. Now a 
dog barks, and the boys know that Bowser has safely treed a squirrel. Before you have had time to collect your thoughts a lusty farm boy, perched on a creaking wain, whooping loudly to his team, goes rattling by. Stay a week and fuish your composition, and see how fast your children are securing disjointed fractions of an education. A half-hour of continuous, quiet, intensified study at home is worth more than a day in many a school-room where little muddy driblets of knowledge are being doled out to the children.

You may say that you have no time to teach children. Business is too pressing, and you are already overworked. You should have thought of that sooner, and been wholly selfish and saved the money and time you spent to persuade that beautiful maiden to join you and help perform the duties and functions of life.

You will certainly agree that home education is the best, the ideal education. For a child, an hour or two of study and recreation a day, an equal time employed in useful work, and the rest of the day spent in picking up fun and facts, both of which may be found in abundance on the old farm, is the natural way to secure a broad primary foundation, upon which to rest a liberal education.

After the child has reached thr age of ten or twelve and has had careful home training, 


\section{Preserve the Home life}

what provision can be made for continuing its rducation during the next four to six years? Two or more districts might be joined to form one, for graded school purposes. On every farm is, or should be, a spare horse and a light wagon; a few dollars would provide a stable near the school building. Such an arrangement would permit the children to drive to and from the central school, although the distance might be two or three miles. All this means that the children will be around the family fireside in the evening instead of on the street, as is too frequently the case when they are sent to the village or city school and remain during the week. All this keeps the boys and girls in sympathy. and healthful touch with home life and their parents, until character has been strengthened by age and knowledge. Here, in these country and village graded schools, the home life, with its restraints and duties, is preserved. Only the mentally strong or the courageous and aspiring will seek the halls of higher learning, from which, if they tend to go astray or neglect their work, they are quickly returned to the bosom of their families. If the central graded school is impracticable in some cases, then a few families might join and employ a private instructor ; this would be far cheaper and more satisfactory than to send the children away from home. 
It is not so much lack of facilities as a lack of an appreciation of the true value of an education which lebars the country youth from securing even a wholesome and logical primary education. The value of an education for citizenship must be placed first, and its value as a money-making power second. Now the first question that is usually asked is, Will an education help to secure a position or to make money? The question, Will an education help to a nobler citizenship? is not even thought of. We shall have no evolution in rural training until the parents secure a clearer conception of the true value of an education.

Evolution along educational lines has already begun, and it is not difficult to see many benoficial effects of the changed methods. M. Demolins' recent book has this to say: "It is useless to deny the superiority of the AngloSaxons. We may be rexed by this superiority, but the fact remains, despite our rexation.'

Considering the superiority conclusively proved, the author proceeds to search for the cause of this superiority. He finds the secret of this irresistible power of the Anglo-Saxon world in the education of its youth, in the direction given to studies, to the spirit which reigns in the school. 'The English and the people of the United States have perceived that the needs of 
the time require that youth should be trained to become practical, energetic men, and not public functionaries or pure men of letters, who know life only from what they learn in books. M. Demolins has personally studied with care some prominent English schools. In these he found the school buildings, not as in France, immense structures with the aspect of a barrack or a prison, but the pupils were distributed among cottages, in which efforts were made to give the place the appearance of a home. They were not surrounded by high walls, but there was an abundance of air and light and space and verdure. In place of the odious refectories of the French colleges, the diningroom was like that of a family, and the professors and director of the school, with his wife and daughters, sat at table with the pupils."*

Here is seen the beginning of better methods in primary education. In the rural districts of America, this system needs but little modification to fit it to the rural home. All else must yield to the inborn rights of the children. If that Brussels carpet which adorns the dark and unused parlor must be pulled up and some of the worst pictures relegated to the garret, in order that provision for a school-room for the children of the family or for those of the immediate neighborhood may be made, then pull

*Editorial, " Literary Digest," July 2, 1898. 
it up. Receive the visitor in the sitting-room or on the veranda, and let the neighborly chat be where there is "air, and light, and space, and verdure."

Reduce the above picture of an English school to suit environment, and we have the family as a unit; the mother and her companion as teachers; and we shall have not only the appearance of home, but a true home, where duty commands and love obeys. This is no far-fetched picture; it is one drawn from many observed instances of these farm home schools. The youths on the farm have a right to a liberal education if they desire it; they own the earth, and why should they not have the best it affords if they make good use of what the earth and all that therein is has to offer.

When we come to the higher education, there are good and sufficient reasons why pupils should be massed. At the college, expensive and rare appliances, great laboratories and museums, ample and expensive libraries, and distinguished and able teachers, must be provided. Then, too, the pupils of the college have arrived at that period of maturity which gives them a fair degree of self-restraint and discretion.

Commected, as I have been for more than a quarter of a century, with college life, I have had many opportunities to observe the fresh- 
ness, vigor and purity of many of the country lads and lasses who come directly from the healthy, solid home instruction of their parents.

I am well aware that this chapter will not revolutionize rural primary education. I do not want it to do so. Revolution destroys ; evolution builds. But if these brief words of one who received until near manhood the thoughtful, loving home training of a mother, who said, "I received a better education than my parents did, and, come what will, I determine that my children shall have better opportunities for securing an education than I had," shall persuade some that the farm home is the natural, the appointed place for training children until they have passed the critical mental and physical period of life, I shall be content. 


\section{CHAPTER IV}

SELECTION ANT PCRCHASE OF FARMS

In selecting a farm, many things should be considered. One purchaser may lay stress on the quality or productivity of the land, another on its location as to market, another as to the outlook or scenery, and another as to the society in the immediate locality. Some would be unhappy if far removed from city or town, while others delight in many broad acres far removed from the busy crowd. All these different phases of the subject, with many others, should be considered before the purchase is made. It is seldom that a farm can be secured which fulfils all desirable conditions; therefore, such choice should be made as will most fully meet the desires and tastes of the purchaser.

Some farms are purchased with little or no thought of their producing a livelihood, while others are selected largely for the purpose of securing profits in their cultivation, and others are bought because they are expected to furnish safe and profitable investments. It is evident 
that no specific or even general rule can be formulated which will be applicable to all purchasers, since tastes, training, needs and desires of the purchaser vary widely; nevertheless, a discussion of the subject may be profitable. Those who secure their income and profits by agriculture alone should lay stress on four things ; viz., healthfulness, environment, quality of land, and water supply.

Without health, life often becomes a burden; therefore, climatic conditions, soil and surroundings, so far as they relate to physical and mental vigor, should be considered first. But health and vigor are not all, for if the moral, intellectual and social conditions of the people in the neighborhood are undesirable, the children may take the road which leads towards semi-barbarism. This road is open to all, in rity and country, but parents should aroid thrusting their children into it. Church, and social congenial and God-fearing associates should be accessible to the growing family. Children are and must be active, physically and mentally, if they are to grow straight; and if provisions are not made for directing their energies into proper channels, they are likely to find improper ones. Wherever the farmer sows not a full abundance of good seeds, weeds are certain to spring up. The farm must provide a fair and liberal in- 
come, because want brings lack of true pride, breeds carelessness, even hatred of other's, filches self-respect and courage. Therefore, if profits are desired, good land, land of wide agricultural capabilities, should be selected. The greater variety of crops the land is capable of producing and the more varieties the farmer raises, provided he does not exceed his mental and executive capabilities, the better will be his education and training.

Frequently the purchaser has too little means, and feels that he must secure cheap lands, which too often are situated far from the railway markets and centers of activity. In such a case, he places himself outside the activities of the towns, which are extremely helpful to him if he be wise enough to choose the good and refuse the evil which they offer. Of course, much depends on the good sense of the parents and the inheritance and training of the children as to how much they will imbibe of that which is good and how much they will refuse of that which is evil. Children cannot be placed entirely beyond evil influences, but they can be prevented from becoming too familiar with them.

"Vice is a monster of so frightful mien, As, to be hated, needs but to be seen; Yet seen too oft, familiar with her face, We first endure, then pity, then embrace." 
Alrearly something has been said with regard to an abundant supply of water, but it may not be ont of place to emphasize the necessity of securing healthful water for household purposes. Modern science has revealed the fact that a large number of diseases are introdnced into the system by means of drinking water (see Chapter XII). All drinking water may be boiled; it may be said that it should be, for in too many cases water that appears limpid and pure, drawn from sources which have every appearance of being uncontaminated, is not only dangerous but sometimes deadly. Careful physicians recommend that all water be filtered, but so many of the filters are imperfect and are so badly neglected that there is no certainty that filtered water is entirely safe; therefore, it may be said that the only safe way is to boil all drinking water. As the streams and soil becone more and more contaminated by unsanitary conditions, it is only in rare cases that safe water can be secured naturally. When wells or streams become low, or when streams are quickly flushed by heary rains, invariably there is danger that the water which they contain may be impure. Care should be taken to provide an abundance of water, and that used for household purposes should be treated in such manner as will make it entirely healthful. 
Having discussed the subject from four leading standpoints, those of less importance may be taken up. It is usually not wise to purchase a farm, however well it may fulfil the requirements of healthfulness, desirable environment and productivity, if the lands by which it is surrounded are poor, since man, in one respect, is like the tree toad, which partakes largely of the color of the thing to which it adheres. The French have a proverb which runs in this wise: "Tell me where you live, and I will tell you your name." Translated into modern thought, it would read: "Tell me your enviromment, and I will tell you your character."

Beauty of natural scenery may not be entirely ignored, although itility, the dollar, must be kept prominently in view. One can afford to economize in the living expenses in many ways not dreamed of by those who load the farm table with a superabundance of good things, if it be necessary to do so, to secure beautiful surroundings. It may be only a question of choice between a moderate subsistence and a reposeful environment, or an overloaded table with uninspiring surroundings. Natural as well as artificial beauty and pleasurable environment have their values. A certain lot on one street sells for $\$ 1,000$, another one on the same street for $\$ 500$. They are both within easy reach of 
the business center, on the same street-car line, of the same size, and have the same elevation. Why the difference in price? Because of enviromment. A seat in the dress circle at the theater costs a dollar, one in the peanut gallery ten cents. The play can be seen as well with a glass in the cheap seat as in the more expensive one. Then environment has value, as well as land and buildings.

The value of the farm may be greatly modified by the improvements upon it. It is well to ask, Is the house well located? May it not have to be virtually rebuilt before it is at all satisfactory? Will it be necessary to move and repair barus before they are at all suited to their purposes? The improvements may be too extended for the needs of the purchaser. Some farms are overloaded with buildings (Fig. 4); some have badly arranged, unsightly buildings, too good to destroy and too ugly and unhandy for either economy or pleasure. Farm buildings are not a direct source of income and are expensive to keep in repair; therefore, there wonld better be a slight deficiency of them than an ill arranged surplus. All other permanent improvements, such as orchards, plantations, fences, and the like, should be carefully considered. A good bearing orchard of only a few acres may serve to furnish enough profit each year to liq- 
nidate taxes and interest charges. The orchard may be cheaper at $\$ 00$ per acre than the balance of the farm is at $\$ 75$ per acre, or it may be only an incumbrance of good land. Is the farm naturally or artificially drained? If not,

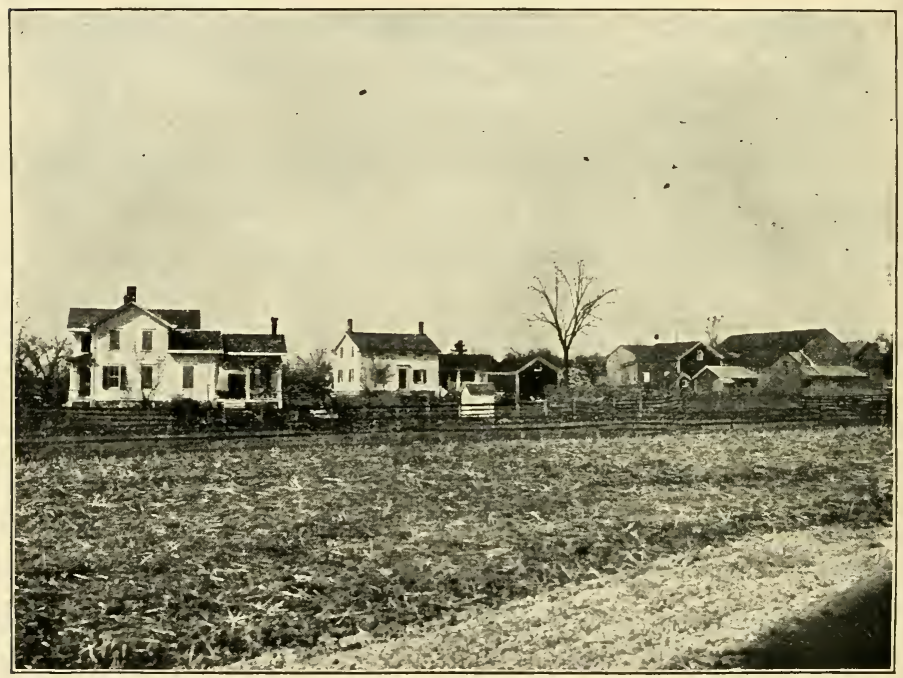

Fig. 4. Too many buildings for eighty acres of land.

will $\$ 35$ per acre have to be spent in thorough draining before the land is really satisfactory? If not drained, will it bring constant disappointment? Fences, lanes and the necessity for them, the amount and location of inferior land as pasture land, the kind of weeds abont the farm, as 
well as the amount, kind and location of timber, should be considered.

Land devoted to market-gardening should be near the market town where the perishable products are to be sold. Vegetables should reach the market early in their season in a fresh and presentable condition and cheaply, if satisfactory profits are desired. Then land which can be tilled early (warm or sandy land), though it may contain a comparatively small amount of natural plant-food, will be more satisfactory than rich, cold land situated farther from the market. An acre of poor, sandy land near the market may be worth, to the gardener, three or four times as much as an acre of the more distant fertile upland.

Near the town, manures, which are so necessary to force many market-garden products, can be procured cheaply and in abundance. The added distance of even one or two miles from the switch or shipping station may have an important effect on profits. Land situated far from market may well be deroted to stockraising and such other products as may be marketed infrequently or at leisure. As yet, agricultural methods in America are so new that they have not adjusted themselves to the growing cities, nor have specialized crops found their appropriate localities. Too often are seen truck 
farms located half a score of miles from the city, and the meat-producing farms within sight of it. As the country becomes older, the raried activities in agriculture will fit themselves into their appropriate localities, as they have already done in many parts of Europe. The dairyman of the Channel islands has long since learned that the piebald cattle of the poulders are not suited to his wants, and the boer of the lowland knows that the meek-eyed, thin-skimned Jersey is not best adapted to his cold, windy country and wet pastures.

Cost of tillage should be considered when valuing land. When produced on friable land, crops may be secured at much less cost than on tenacious clay. On the other hand, while sandy soils are the most easily cultivated, they are ever demanding more plant-food, and hence are not well adapted to grass or general agriculture, as the expense of keeping them productive is usually so great as to preclude profits.

Except in special cases, as in truck farming, it is cheaper to purchase natural plant-food in the soil than artificial fertility. One acre of land may have potential plant-food sufficient under superior tillage for one hundred crops, while another unaided will yield but half as many, and yet the two pieces of land are often priced at the same figure. In other words, land 
of high productive power is usually cheaper than land of low productive power. A good farm may be cheaper at $\$ 50$ per acre than a poor one as a gift.

Last, but not least, is the road to the farm. Every free-bor' American demands a public highway in front of his house; if far'ms are small there must then be a highway about every mile, or, at most, every two miles. This leads to cutting up the country into enlarged checkerboards, to a multiplication of highways so great that none of them can be kept passably good without overtaxing the land which adjoins them. On account of the contour of the land over which they pass, some roads are extremely difficult and are well described by the man who, when asked how far it was from a certain town to another one, answered: "Thirty miles, and it's up hill both ways." As I write this I look out upon a washed clay road which stretches up and on towards the horizon for six weary miles, so steep that the team must maintain a walk for the whole distance in ascending or descending. What is land worth at the other end of this road, as compared with that which lies six miles away in the other direction, along a smooth, level pike? Every grown farm boy should have a good horse and a good road upon which to 
drive, if he be worthy of such a noble animal as the horse. When he starts for himself let him locate on a good road. There are always enough persons who are not thankful for advice, especially if it be in a book, who are looking for cheap land at the end of the hilly road.

Many farms are purchased by young men just starting out in life before judgment has been developed by experience, while men of mature years take in the whole problem, or rather series of problems, easily and at once. The novice would do well to make a list of the topics enumerated above, and add to them such others as appeal to his tastes or conditions and then study them, one at a time; in fact, there is nothing left for the young man to do but to make out a score-card upon which he records his judgment in numbers as he investigates each phase of the difficult problem of selecting a farm. 


\section{CHAPTER V}

THE RELATION OF THE FARMER TO THE LATTER

Doubthess more than one reader will be astonished, perhaps even horrified, to think that the writer should seriously suggest that there ought to be any relation whatever between the farmer and the lawyer.

It has come to be generally believed by many farmers that lawyers are at best a necessary evil, which it is well to avoid if possible; but, strange as it may appear, this very feeling is responsible for much of the litigation, with its attendant loss and sometimes ruin, in which too many farmers have been engaged. It is not the purpose of this short chapter to treat of the subject of law, or to try to lay down any rules to be blindly followed in legal matters. An old and learned lawyer, who had all his life been engaged in a country practice, once told me that the most prolific sources of litigation were alleged text-books of law, bearing such alluring and seductive titles as "Every Man his own Lawyer", or "The Farmer's own Law Book." 
Several years ago, a wealthy manufacturer of the state of New York sent a bright son to a law school, to help prepare him for a business career. At the end of his course the proud father was present at commencement, and, in the course of conversation with his son, said: "Well, John, I suppose you have learned a great deal." John answered, "I have learned one thing which I think is of value; and that is, if any legal matter comes up in the course of my business, to consult the very best lawyer I can find." That young man had really learned something worth far more than the cost of his course in the college of law.

There is, perhaps, no other of the so-called learned professions which is so exacting and which requires more devotion and study for its mastery. Some of the brightest men in this country have devoted a lifetime to the study and practice of law, only to have just entered its broad field as they have been compelled to lay down their work. How futile, then, would be the attempt to make every man his own lawyer! The real purpose of this chapter is to open the eyes of the farmer to the necessity of a closer relationship between himself and the lawyer, - the family lawyer, if you please, having his confirlence to the same retent as that of the fimily doctor. 
Most farmers desire a comfortable and a beautiful home, and it is to aid such that this book is written. Such a farmer would doubtless consult a builder or an architect as to the foundation, walls, plan and materials of the home to be constructed, and he would act wisely; but how many would think so far as to consult a lawyer as to the very foundation upon which his home and his future happy occupancy of it rest: the title to the farm. Too many times he is satisfied with the services of the village solons, - the shoemaker who is a notary public, the justice of the peace, or the pettifogger who daily overrules the supreme court or the court of appeals. Years after he has purchased his farm, he finds, perhaps, that some man has given a deed whose wife has not signed, and upon the death of the woman's husband our farmer friend is confronted with a law suit; and he finds that this wife, who did not sign the deed, is entitled to dower in his farm, the use of one-third of its value at the time her husband gave the deed, for life. Such cases are frequent, and might easily be prevented by submitting an abstract of the title to a lawyer at a cost of $\$ 5$ or less. The flaw in the title may be a nortgage or judgment, or a failure of all the heirs of a deceased person, somewhere along the chain of title, to join in 
the deed; all of which might be overlooked by the ordinary business man, and yet be readily letected by a lawyer.

Some day the farmer may be annoyed by the encroachment of a neighbor upon his farm, and, when in the midst of a litigation, find that the description of his farm is so defective that there is no relief. I have in my possession a deed of a valuable farm containing this description: "Beginning on the road at the south end of a pile of four-foot wood; running thence westwardly to a black cherry tree, thence northerly to a stake, thence easterly to a pine stump in the center of the road, and thence southerly to the place of beginning, containing 100 acres, more or less." For fifty years this description has been copied, a score of times, by the various justices of the peace and notaries public of the neighboring hamlet, but fortunately, however, it has never derolved upon the owners to establish the boundaries of that farm. The first lawyer who got hold of this particular deed insisted upon such a description as would be tangible and certain. Not many years ago a mortgage on a valuable farm in Tompkins comnty, N. Y., was forerosed, and during the foreclosure it was discovered that this mortgage covered about fifty acres of Cayuga lake, and what had been sup- 
posed to be a valuable mortgage was depreciated one-half by reason of the neglect and incompetence of the country conveyancer.

So, too, there are questions as to line fences, water courses, rights of way, encroachment upon the highway, and an innumerable train of threatening evils, continually arising, any one of which, if neglected or referred to the many wiseacres common to every community, may lead to costly litigation, or even to the loss of the farm itself. A bit of counsel at the right time, which is when the matter first appears, will prevent, at trifling cost, all the attendant evils of a law suit.

Such instances are very common in the experience of every lawyer who enjoys even a moderate country practice; and it is an alarming fact that perhaps fifty per cent of the titles to all the farms, especially in the older states, have flaws more or less serious, any one of which is a microbe of trouble, liable to assert itself when least expected. This being so, the general and inflexible rule should ever prevail, never to take a deed of property without an abstract of title which has been examined by a competent attorney. The so-called maxims of law, often repeated and distorted, especially in farming communities, are extremely dangerous to follow. They may have some foundation in 
fact, but as almost all rules of law have their exceptions, and as no one not versed in the law is competent to pass upon them, they should never be blindly followed by a layman.

To illustrate this point: Not long ago a prosperous farmer, relying upon the oft-repeated assertion that twenty years of peaceable possession gave title, became involved in a lawsuit with the town over a fence which had been built in the highway adjacent to his farm. He was an astonished man when the lawyer whom he consulted told him that possession for a thousand years of the land claimed would not give him title as against the public.

It seems almost incredible that a farmer, who will drive his horse for miles to have him shod by an expert, or who will summon a veterinarian to treat a sick cow, will be satisfied to consult what someone has brightly termed a necessity lawyer,- - because necessity knows no law,- upon matters affecting his farm, his home, or his competence, rather than the experienced lawyer. The cow might be replaced for forty or fifty dollars if a mistake was made, but the farm, the competence, have cost a lifetime of labor.

Perhaps the most striking example of neglect on the part of the farmer is in regard to the disposal of the fruits of his life-work. It is 
true that anybody can draw a will, and yet the fact that men and women allow anyborly to draw their wills is productive of more fat fees than arise from any other source. Not long ago an acquaintance, who did not realize the truth of the old adage that "a little knowledge is a dangerous thing," drew his own will, and, being childless, sought to leave his property to his wife, who had been the partner of his labors in a long life of toil. The law of the state of New York requires two witnesses to a will. He procured only one, and upon his death the property, which husband and wife had with so much toil secured, was for the most part scattered among distant relatives, almost strangers, because he was afraid of lawyers and their fees.

In all the varied business which a farmer will meet,- the giving of notes, mortgages, etc., or, better, the taking of mortgages, bills of sale, and promissory notes, - it is well to remember that different conditions of fact make necessary different interpretations of the law, and that it is usually unsafe to follow a neighborhood precedent. Oftentimes you may be called upon to transact business where it is not convenient to consult a lawyer. In such cases, and in all transactions of any magnitude or possible importance, all talk, or the essence of it, should be reduced to writing. Then it camnot get away 
or be distorted or forgotten, and is in good shape to submit, at the first opportunity, to your lawyer, who, if an error has been made, can, while the matter is fresh, more easily correct it. Remember that a contract is simply a meeting of the minds of the contracting parties, and the best drawn contract possible is one that states, in language simple and concise, what each means as expressed by word of mouth.

Most of the litigation so much feared by the farmer is due to the farmer himself and his neglect to seek an ounce of preventive. It is true that there are rascally lawyers; so, too, there are dishonest men in every trade, occupation or profession, but they are generally easily located.

If this chapter shall lead the farmer to feel that his business is farming, that "a jack-atall-trades is master of none," and that the law, justly interpreted and enforced by those who know it thoroughly and well, is to be the foundation of his success, the guarantee of his home through life, and the channel of its proper disposal after death, then it has not been written in rain. Remember that the province of the true lawyer is to keep his client out of trouble, rather than to get him out of trouble. An honest lawyer, of whom, thank Heaven, there are very many, notwithstanding the popu- 
lar prejudice of those who have suffered from litigation, will always try to steer you clear of litigation and loss.

In conclusion, then, always consult a lawyer in matters affecting your farm or property. The average fees of a lifetime will not exceed fifty dollars, and oftentimes valuable advice will be given free. Select one in whom you have confidence, and stick to him. Become his friend, and let the relation be one of mutual confidence. Do not neglect to ask him a question because you fear he will think you dumb; he probably knows less about farming than you do about law. He will need your advice and influence in minor matters as much as you need his. Call on him when you are in town, and he will be glad to see you. Very often he will answer your question gratis. When he charges you what may seem a large fee, remember that you are paying for skilled labor, and that you are entitled to expend as much for the possible welfare and happiness of your family as you expend upon the choice stock in your stables. Farmers, more than any other class of men, perhaps, are prone to neglect legal matters, or place them in incompetent hands. 


\section{CHAPTER VI}

\section{LOC.ATING THE HOUSE}

Srnce more than three-fourths of the life of the farmer and his family are spent in sight of home, more than one-half of life in the house, and more than one-fourth in bed, the house, the place where they live, should receive most careful attention. Having secured sufficient land to maintain a home, and having made certain that these lands are productive and profitable, a problem is presented in locating and building the house which demands a high degree of intelligence, long, painstaking study, and a good understanding of what constitutes fitness, beauty and durability.

Life in the country gives one the idea of repose, of strength and breadth, of largeness, of solidity and durability, of healthy, symmetrical, solid development. Things which are evanescent, unreal, shoddy; things which are simply for show or vulgar display; things which have the appearance of aping that which may be appropriate under different conditions, but are totally out of place in rural life, must be 
avoided if utility, natural beanty and comfort, economy and repose are to be secured.

The pioneer in the wooded districts built the home in some sequestered nook or valley at the base of the hill or table land, where the spring or the stream issued from the wood-covered heights. The rural house of the pioneer allowed free circulation of the frosty air; the problem of rentilation they solved without knowing it. Unwittingly they adopted the correct principle; viz., ventilation by many small, gentle streams of air instead of by a few large openings, which create dangerous drafts. It must be admitted that our forefather's overdid the ventilation in most cases, and rheumatism and chilblains were the result; but the principle was correct.

Now the spring has dried up, the water from the deforested hills comes rushing to the lowlands until the streams overflow their banks, and these and other changed conditions indicate that the future farmsteads should be erected on higher land, on the slopes of the hills. From the one extreme we have gone, in some cases, to the other, and the home has been built on the very apex of some lofty hill. Such locations may be well adapted for summer residences, where little or no farming is carried on, but are not suitable for the farm home.

Now that the house is constructed by more 
skilled workmen than formerly, and out of better material, there is little need of locating the home in the sheltered nook, except possibly in the extreme north, or on plains subject to tornadoes. The object in locating the house on somewhat elevated lands is fourfold. First, air drainage. In deep, crooked, narrow valleys the air is pocketed, especially at night, and the damp, cold air settles in the lowest land as certainly as water finds the low-lying pool. In these pockets between the hills, frosts come early and remain late.

While traveling in western North Carolina in the late summer and fall, I could not but observe how every little break in the hillside and every narrow valley was filled at sumrise, to the crest of the adjoining hill, with a dense fog. Slowly the sum, as it approached the zenith, dissipated the fog, but the narrow vallers were often free from fog for only a few hours each day. Here the home might be situated well up the mountain side, as shown at the right in Fig. 5.

In a little pocket about twenty feet deep, formed by hills, with a road embankment at its month, fruits failed, although they flomished on the adjoining land, where there was good air drainage (Fig. 6). If fruits do not thrive on these undrained areas, the natural conclusion is that the children will not. It is found 
that the upper stories of city buildings are healthier than the lower ones, and that the ground floor is the most unhealthy of all. This is the only objection to a one-story house. On

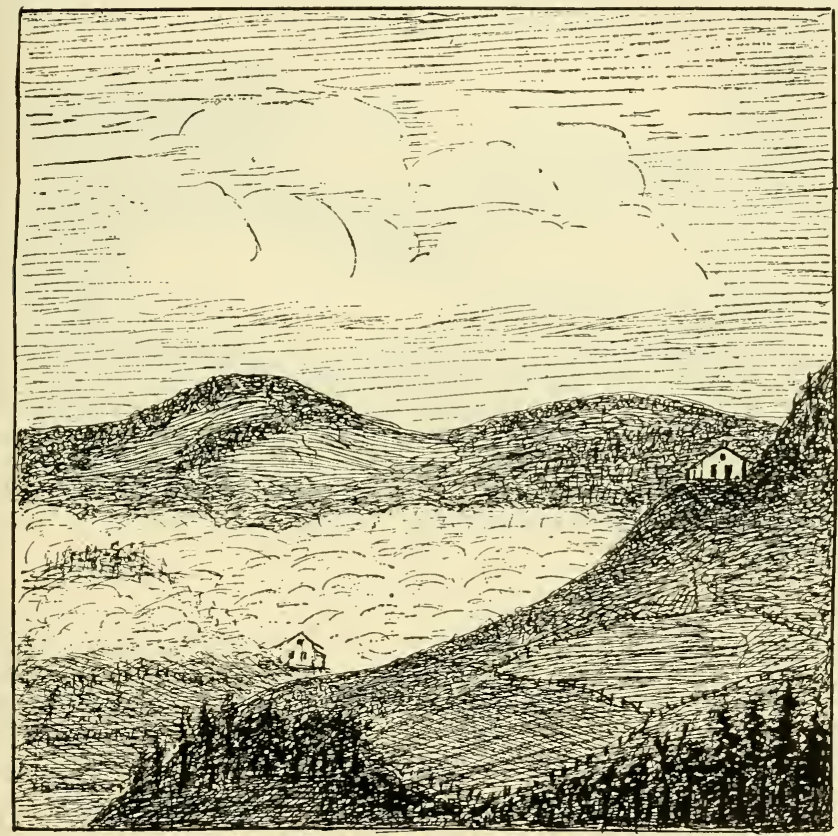

Fig. 5. A house in the bottom of the valley and one on the mountain side. the level prairies little opportunity is offered for locating the house above the level of the surrounding country. Fortunately, many of the prairies are undulating, and furnish most beautiful locations for country homes. Much may be 
done, even in the level country, to overcome the disadvantages of the site by placing the cellar of the house only two or three feet in the ground and grading up to within a short listance of the top of the wall. A pool or

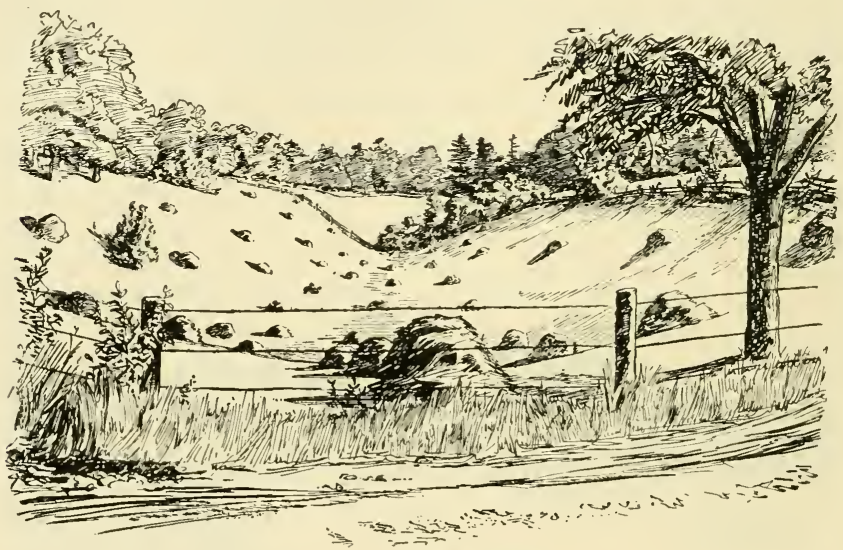

Fig. 6. A frosty pocket.

two, or a miniature lake near the barns, and skilful planting of trees will lend a diversity and charm well worth the attention and time given to them.

A pool may be made by scooping a place in hard earth or by damming a stream (Fig. T). If no water is allowed to flow over the dam and it is raised some two feet above the orerflows, it will serve every purpose as well as an expensive grout or stone structure. It will be noticerl in the picture that provision has been made by 
digging shallow ditches on the right and left for carrying off the surplus water when the miniature lake is full. In constructing the dam, a trench two feet wide, at right angles to the stream, should be dug to the depth of one foot,

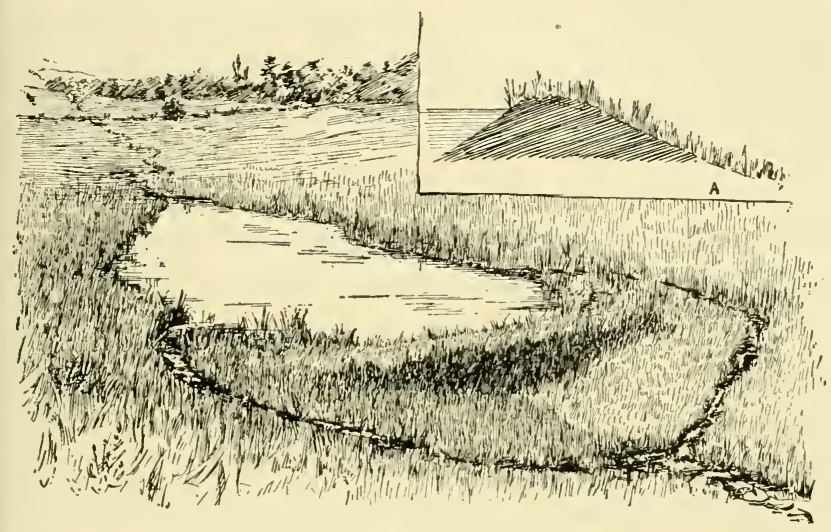

Fig. 7. A useful pond.

or until solid ground, unmixed with vegetable matter, is reached. Fill the trench with clayey earth which is free from humus, which will prevent the dam from leaking at the bottom where it meets the natural soil. The stream which feeds the lake or pond should be small, and need not be perennial if the dam is raised as high as it should be. If the water is dammed back to the depth of twelve to fourteen feet, and the banks of the pond are rather steep (A, Fig. 7), a cool, useful miniature lake will 
be formed, and not an unsightly marsh, during the dry months of summer.

Dryish, gravelly soil and subsoil is to be much preferred as a site for a house to clayey or dark, damp soil which contains much humus. If the ideal soil cannot be secured, then thorough drainage should be provided. In locating on a gentle declivity, there is a constant tendency for water to penetrate the wall next the hillside or to pass under the wall and appear in the bottom of the cellar. Unless this can certainly be prevented, another location had better be selected.

The house should be situated on somewhat elevated ground, to promote both surface and house drainage. If it is the purpose to introduce into the house more water than has been furnished heretofore, then full provision should be made for carrying all waste water and fecal matter to a safe distance from the house, and to do this beyond a peradrenture, sufficient fall must be secured to give permanency to the work and an unobstructed outlet.

One of the objections urged against a country home is that it is "too quiet," too much shut up from the outside world. This, in part, is true. It detracts much from the enjorment and beanty of the country home if vision is shut in to a few acres just about the house. The American farmer is not content to live under the 
conditions which delight the Transvaal Dutch farmer, so isolated that he cannot see the smoke from his neighbor's chimney nor hear the bark of his neighbor's dog.

When visiting the home of the Hon. Edwin Morgan, I found that he was having three large trees cut down. It seemed to the uninstructed like vandalism. When asked the reason for sacrificing these noble trees, nourished and tended for half a century, he answered: "I have many more trees, but I have but one lake - Cayuga and I must have vistas through which I can watch the white sail, the crested waves, the everchanging colors of the water as the winds open vistas in the fleecy clouds. I love the trees not less, but the soft reflection of the moonbeams on the rippling wave more, and so the trees must give way."

The outlook from the vine-covered veranda should be broad and extended. If possible, the hill and dale, the stream and wood, neighbors' houses nestled in plantations of trees and shrubs, all should be in sight. As life advances, I see more and more clearly the effect of that noble lake, its now boisterous now placid surface of the rippling water which laved the stony bearh. I see its effect on that "tow-headed" lar who at one time breasted the wares, at another" sat dreamily casting pebbles into the clear ex- 
panse, wondering what life had in store, what the great unknown world offered for the nutbrown, high-tempered, crude country boy. Then plant the country home where nature in her happiest moods has showered her richest gifts!

But beauty loses much of its charm where healthy vigor gives not the power to appreciate and enjoy it. So the house should be located on a healthy eminence. But it is not easy to find a location which shall combine convenience, beauty, air and water drainage, and healthfulness all in the highest degree. In the case of the farmer, convenience as to carrying on the various operations of the farm and healthfulness are paramount. Drainage may be artificially improved, vistas opened, miniature lakes constructed, and surroundings made more beautiful. 'The farm and its equipment is the workshop, and must be convenient in all its appointments, or much energy is spent for naught; health must be maintained at the highest, or work may become but toil and drudgery.

In loeating a house, its relation to the size of the farm, its productiveness and agricultural capabilities should be considered. In locating the site, two places should be carefully aroided: First, at the end of a long lane in the middle of the farm. It may be said that the buildings form the natural nucleus in and around which 
the work centers, and therefore they should be placed near the middle of the estate. But the work carried on in the fields forms but a small part of the farmer's activities. He must ever, in these modern times, be in touch with the school, the church, the post office, the railway, the market, and his neighbors. When an infrequent call is made at the end of this long lane, the children appear like frightened deer as they seek shelter in the shrubbery or behind the corner of a building, and the more the inherited timidity and reserve, the wilder they appear.

The other location to be avoided is within a few feet of the highway. Such locations are only admissible in the city, where land sells by the square foot. What fortunes are sometimes spent in the city to secure some amplitude of space between the dusty, noisy street and the residence! What dignity and repose an ample, well kept house-yard gives to even a plain, modest house! The effect of the mistake of locating the house too close to the highway is often accentuated by locating the barns on the other side and immediately upon the highway, and in front of the house. The location of the house, as to the highway, should be governed, in part, by the size and productive power of the farm. If ample acres and means are available, 
then the grounds should be ample; if limited, the grounds should be made to correspond.

In moderate-sized holdings, a clear space of from 100 to 200 feet between the house and the highway, and width equal to or exceeding the length, will give room for a few shade trees and an ample grass plat. The site should be either suited to the house or the house to the site. Therefore, the character of the proposed house and the site should be considered at the same time. One location may be suited to a onestory, another to a two-story house. No location is suited to a story-and-a-half house.

It may be said that on most farms the house is already located, and has grouped around it plantations and barns. In many cases it would be inexpedient to change the site of the house, as this would necessitate many changes of outbuildings and other permanent improvements. But if a careful inspection is made of farmsteads, it will appear that many of the houses are in need of repairs and additions, and that the cost of making them would be but slightly increased if either the house or the outbuildings were removed to a more desirable site. In the great majority of cases, the old barns should be gathered together into one structure, or into two at most, and adapted to the needs of modern agriculture (as will be explained in a subse- 
quent chapter). All changes presuppose well matured plans and long and careful study of problems which will have to be solved if the location of the house or barn is changed.

The scope, and particularly the cost, of the changes should be known approximately before the execution of the plan begins. "For which of you, intending to build a tower, sitteth not down and counteth the cost, whether he have sufficient to finish it? Lest haply after he hath laid the foundation, and is not able to finish it, all that behold it begin to mock him, saying, this man began to build and was not able to finish." Far better live in the old house, with its inconveniences, and get the greatest possible happiness out of the ancient structure, than to build a new one and cover it with shining paints of many colors and a mortgage which sticks longer than the paints.

Some of these old farm houses embody many beantiful and reposeful characteristics, are well located, and need only slight modifications to make them fit the site as nicely as a bird fits its nest. If thought can be awakened as to the possibilities of these neglected homes and some information imparted as to their treatment, or, in other words, if the eyes and understanding can be trained to take in the fundamental principles of beauty, dignity, fitness, and repose, 
we shall soon see fewer architectural monstrosities. That there are not more is a wonder. What lad or lass has ever had the slightest instruction by teacher in rural or city school along the lines of fitness, beauty, and healthfulness of sites for country homes? The few youths who reach the institutions of higher' learning are scarcely better off. Some of these are taught to see the beauties and wonders of nature through a microscope, and, in rare cases, one may be taught to observe the lines of symmetry and form as exhibited in a poor plaster cast of some mythological Roman warrior; but as for any instruction which leads directly to a broad understanding or keen appreciation of nature in her broader, happier, and grander aspects, it is painfully conspicuous by its absence. So, is it any wonder that the farmer is deficient in appreciation of the fitness and beauty of the tree-clad, gently rolling plateau for a home site, when the "liberally" educated fail to see the innumerable beautyspots which corer the face of nature? 


\section{CHAPTER V'II}

\section{PLANNING RTRAL BUILDINGS}

THE farm house is not what is called a "paying investment." It is not a direct source of income; neither can the other rural buildings be said to produce a direct income. Generally speaking, the farm house can fulfil but four purposes if properly planned and well constructed: the house may serve to keep the family warm in cold weather, cool in hot weather, dry in wet weather, and to gratify a love for the beautiful. Since the farm house as a paring inrestment is usually a failure, if it does not supply the wants of the household and fulfil its object, it becomes a failure indeed. The first great mistake which the prosperous farmer usually makes is to invest too much money in expensive, hastily planned buildings. The house should be built to serve its inmates; too often the inmates become the servants of the house. A farmer's wife cannot well afford to devote one room in the overcrowded house to the storage of expensive, useless upholstery and bric-a-brac, nor time to keep them presentable and in order. 
The debt incurred for a part of the purchase price of the farm forbids the employment of help to keep in order this home museum of things useful and beautiful, and things useless and ugly. If plainness, durability, and natural beauty in parlor, sitting-room and chamber would only become fashionable, what a burden would be removed from the shoulders of housewives, both in country and city! The time is at hand when health and intelligence should count for more among American women than show and the possession of a miniature upholstery shop. The furnishings of the rooms should minister to the comfort of their owner, and not tend to make life burdensome.

Not infrequently farmers of energy and ability become possessed of more than a competence near the close of life. Having lived in somewhat restricted circmmstances, they think to make the close of life more comfortable and luxurious. So, notwithstanding the fact that most of the children have left the paternal roof, they set about building a large house, tear down or remodel, and add to the outbuildings; and at the close of life they leave the possessions encumbered and a farm overloaded with buildings as an inheritance to a child unable, by reason of youth and inexperience, to secure a competence sufficient to live and keep up repairs. 
A beautiful farm of 180 acres, in centra? New York, is provided with the following buildings:

Fig. 8.

The buildings on a 180-acre farm.

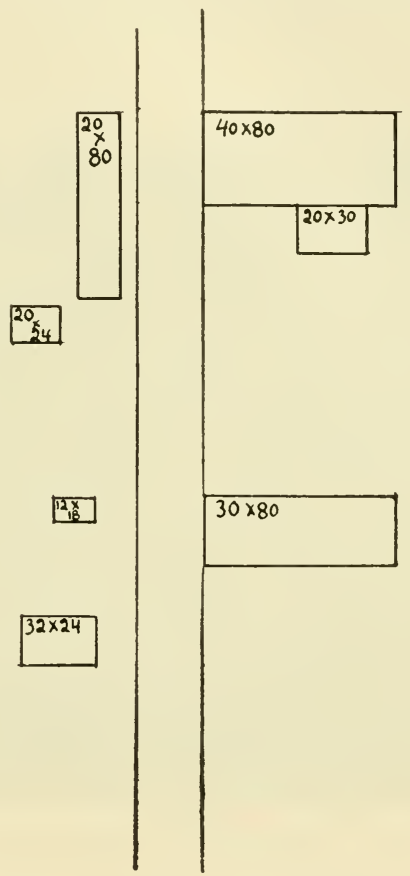

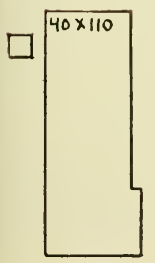

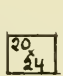

A house, part 2-, and part 1/2-story, 110 feet long.

A horse barn, 30 by 80 feet.

A grain barn, 40 by 80 feet.

A straw shed, 20 by 30 feet.

A machinery and husking barn, 20 by 80 feet.

A hay barn, 16 by 30 feet. 
A cart shed and chicken house, 20 by 24 feet. A piggery, 20 by 24 feet.

A corn crib, 12 by 18 feet.

A carriage house, 24 by 32 feet.

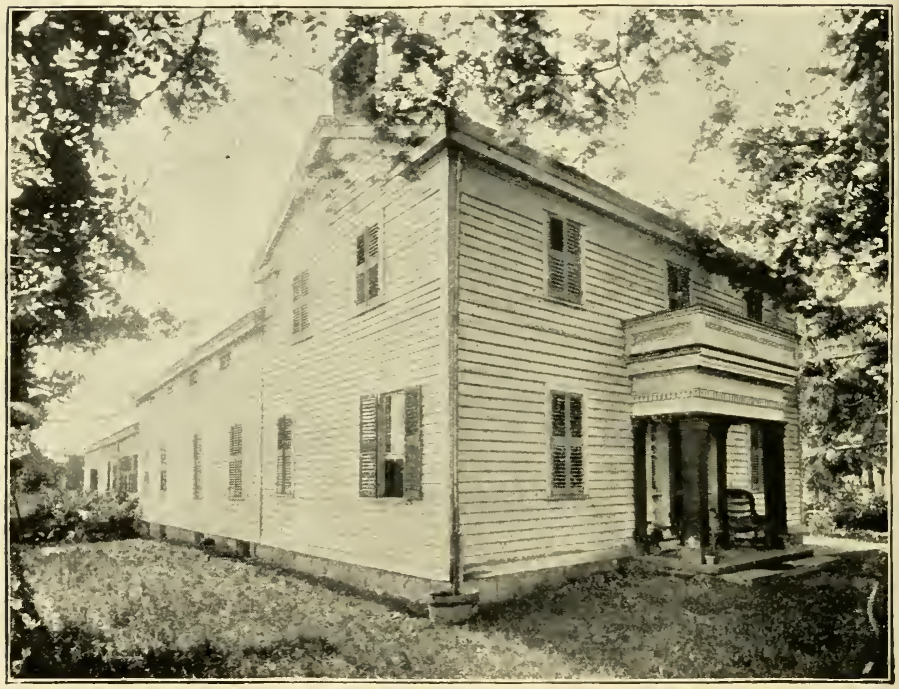

Fig. 9. The farm house that is too big for the farm.

Some of this lay-out is shown in Figures 8, 9 , and 10. These buildings could not have cost less than $\$ 15,000$. A fair valuation of the farm at the present time would be $\$ 14,000$ to $\$ 16,000$. The family which now occupies the house consists of man and wife, one child, and two regular employes, one of whom has his own 
home. The father overloader the farm with buildings, his son is struggling to keep them in repair, and the wife labors to keep unused rooms presentable. These buildings might well serve for a section of land and a family of twenty.

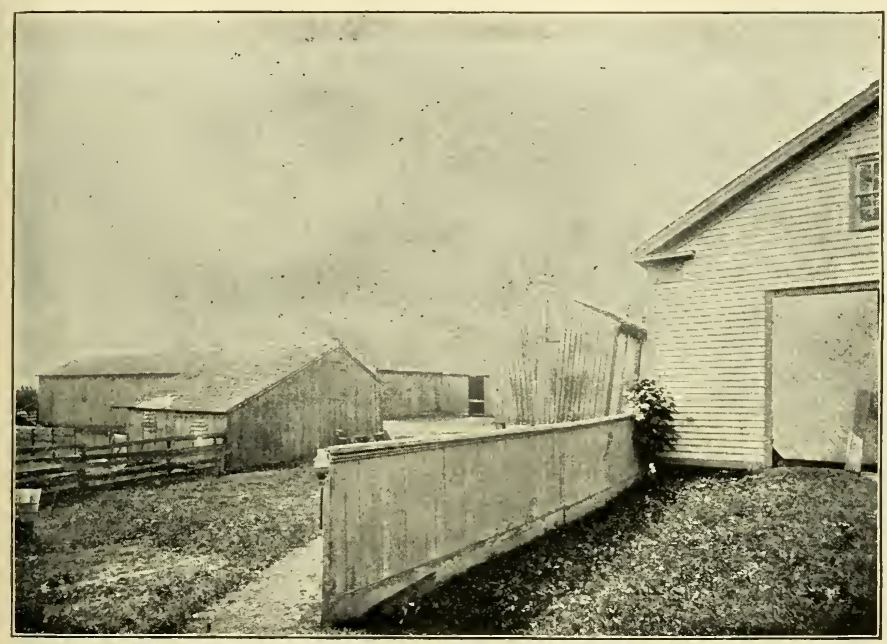

Fig. 10. Scattered farm buildings.

Another house not far from this one was built nearly a century ago (Fig, 11). If the upper story was a full instead of a half-story, it would fulfil all the demands of a house, except possibly beauty. It stands on a rather steep front slope, which stops abruptly on the shore of one of our beantiful inland lakes (Fig. 
12). By reason of the steep incline at the front of the house, a tall building would be far less beautiful than this lean-to, severely plain structure. This simple old house has a restful, almost beantiful appearance when viewed in

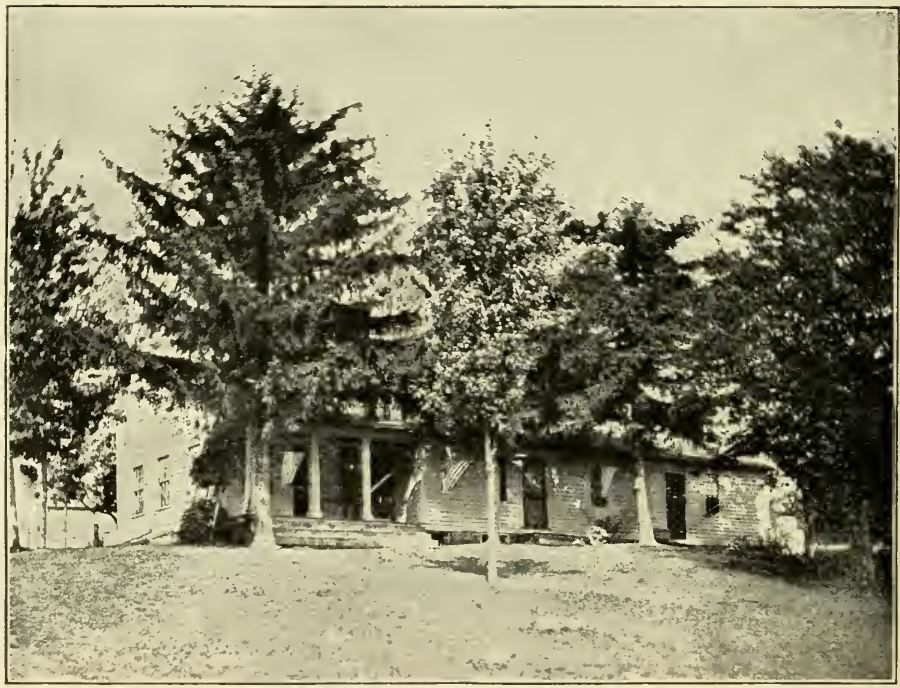

Fig. 11. A cosy farm house.

conjunction with the trees, the steep, sloping lawn, and the broad, placid lake. The shaded veranda gives the idea of social repose far more than does the formal, stiff, restricted one shown in Fig. 9, which has scarcely room for two easy chairs, and is so constructed that no grateful 
shade is secured. Woe be to the man who destroys this restful old house and substitutes for it a lofty, narrow-waisted one adorned with peaks and spires, bay windows and a filigree cornice! Before ground is broken for the foundation,

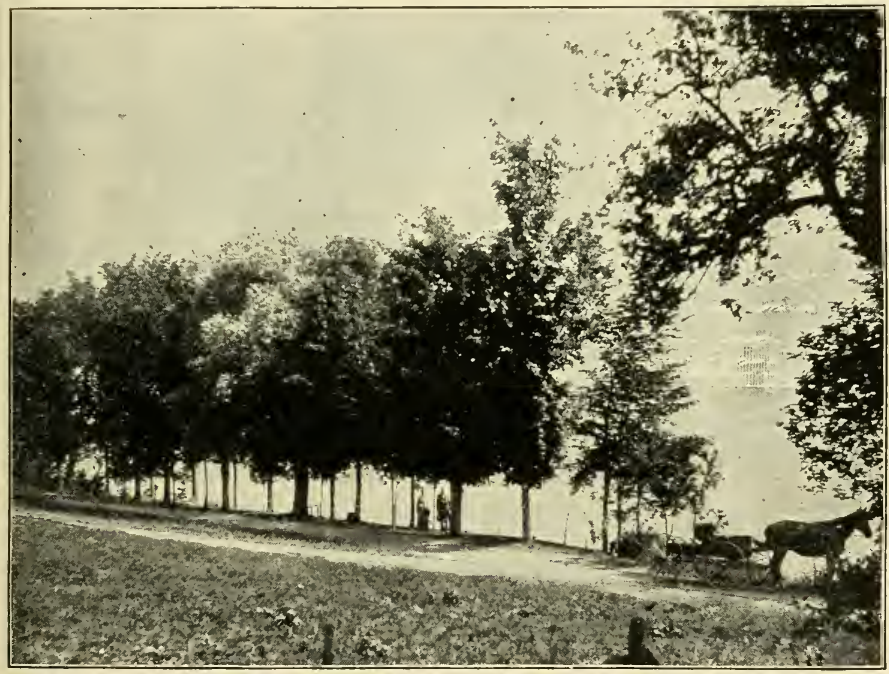

Fig. 12. The lake view in front of the house.

carefully considered plans suited to the site, the size and productiveness of the farm, and the probable income, should have been made. It may he sairl that the size of the house should be governed by the size, or the probable size, of the family. But "it is better to dwell in 
the corner of the house-top than in a wide house" with insufficient means to maintain it. 'The general plans should be outlined at least a year before a new building or extensive enlargement of the old is begun. The houses which are to be built in the future should be planned with a view to greater economy, convenience, beauty, and durability. There is now little excuse for erecting poor, uncomfortable, inconvenient houses on the farm. True, the rural population is handicapped, for few city architects have made any study of the plain rural house, and fewer have paid any attention whatever to farm barn construction. Even if architects had given attention to the needs of the rural population, the farmer would feel that he could hardly afford to pay $\$ 100$ to $\$ 200$ for the plans of a house costing $\$ 1,000$ to $\$ 2,000$, exclusive of the labor which the owner, his men and teams were able to perform upon it. The task of planning a country house is too great for the country carpenter; he cannot even interpret plans correctly; his range of observation and training have been too limited. Then, who is to plan the house? Why, the farmer and his family, and it will take at least two years of study and observation of other houses and their modern conveniences before inteliigent, crude plans and 
instructions are ready to be placed in the hands of the draughtsman.

Few persons are original; therefore, if the little conveniences which help to lighten work

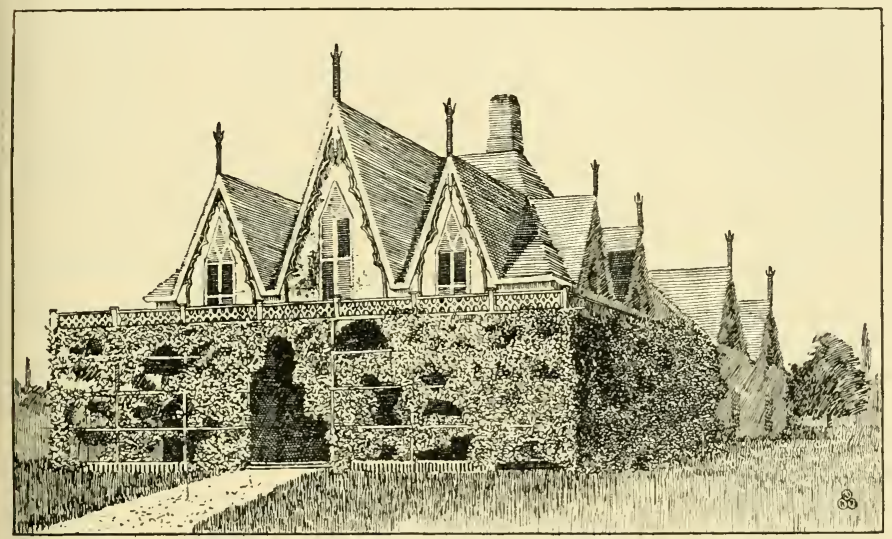

Fig. 13. A house of seven gables.

and make life more pleasurable are to find a place in the house, they must be seen in other houses. All men have more ideas than any one man; therefore, the range of study should be wide, that whatever is suitable to the conditions may be adopted. After having built many farm houses and barns, and having made a long and most careful study of them, I estimate that from 30 to 40 per cent of the cost of farm buildings is useless, and sometimes worse than thrown away. 
A small farm house on a modest-sized farm is shown in Fig. 13. The site is beautiful, and is worthy of a house better fitted to the situation, the farm, and the farmer. The illustration shows seven gables, and the house, therefore, might serve as a model for a work of fiction; but the left-hand side of the house is like unto the right-hand side, so it will not do for fiction, for if the truth must be told, there are eleven gables and twenty-two valleys on this house.

The vine-covered veranda is most beautiful, and looks cool and comfortable, but there are too many vines, and, with the exception of a few days in summer at midday, the air under

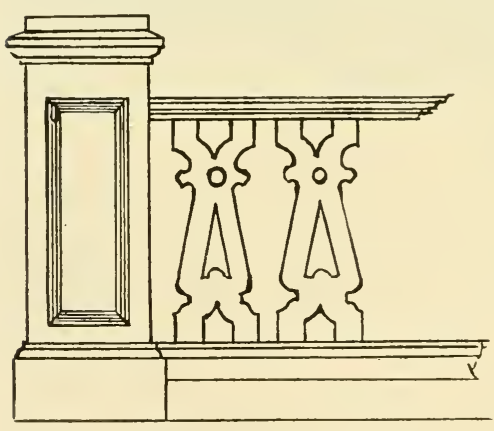

Fig. 14. Filigree work is expensive, and does not look well on a farm house. this veranda would be damp and uncomfortable. It is far better to secure shade by means of awnings and a few tall, well trimmed shade trees, which preclude dampness and permit air drainage, than to overburden the veranda with vines. The covering of this veranda is an unprotected floor, and extends along the front and well around both sides. Notice the too expensive balustrade and frequent fancy posts, an enlarged 
of this house is kept in order. It seems hardly necessary to call attention to the chambers, which, of necessity, must be of such a character as to preclude comfort, beauty and repose.

A house built after the ground plan, Fig. 15, might make a not unpleasing picture in the landscape, but it would not be appropriate for the farm, and would be unnecessarily expensive in construction and maintenance. It would be difficult to heat, on account of the great surface exposure due to the broken out-

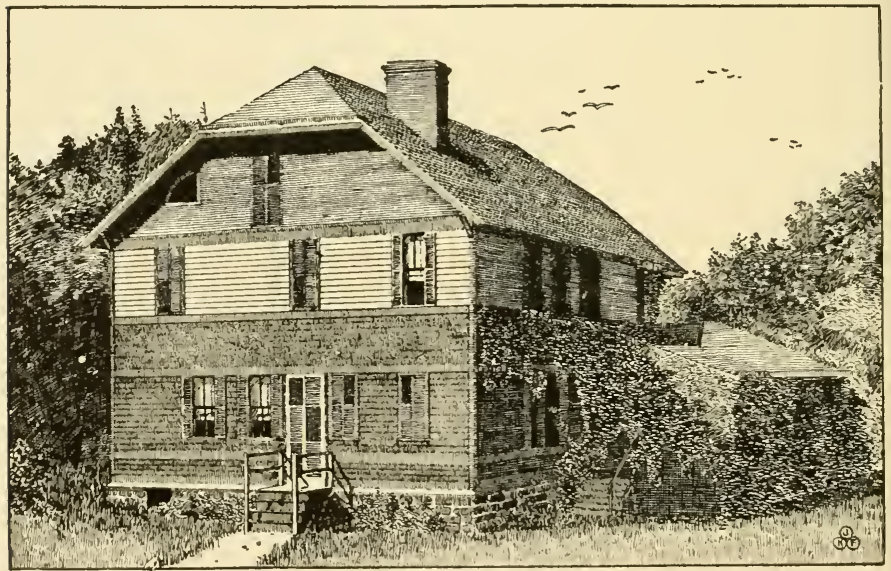

Fig. 16. A good model for a farm house, having strong lines and much character.

lines and numerous corners, which are seldom air-tight. 'The style might not be altogether' inappropriate for a cheap seaside cottage. 
A rear view of a somewhat larger house is given (Fig. 16). It would not cause the passerby to stop and stare. It may be compared

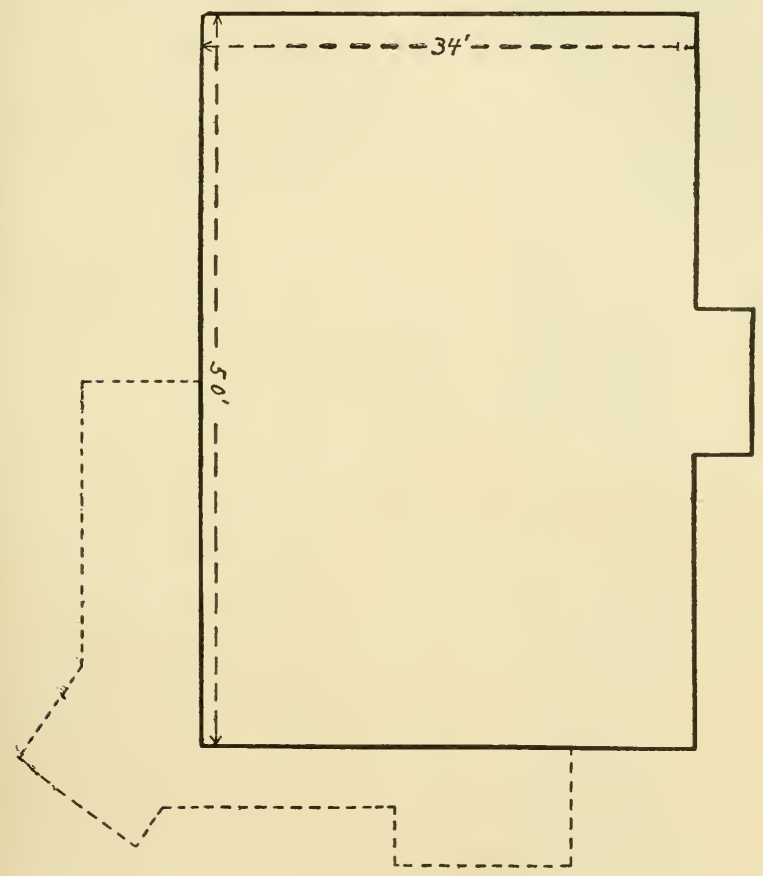

Fig. 17. Ground plan of the house shown in Figs. 16 and 19.

to a well, appropriately, and simply dressed lady, while the other is a reminder of the over-dressed, furbelowed damsel, who attracts the prolonged stare and the thoughtless comments of every sidewalk idler. Here are seen repose, beauty, 
elements of durability, and freedom from expensive ornamentation and repairs.

A back view of this house has been shown purposely to emphasize the fact that the rear side of a house may be made nearly as beautiful as the front side. It would be improved both in looks and convenience if a partially enclosed porch were placed over the door and two of the windows.

The planning of a house is not difficult if wants are clearly defined and the principles of economy, dignity, durability and repose, as applied to the exterior of the house, are fairly well understood. If the site is ample, and it always is in the country, you have but to draw a rectangle, the length of which is one-third to one-fourth longer than its breadth. Fig. 17 is a ground plan of the house shown in Fig. 16.

The farm house shown in Fig. 18 is located thirty feet from a dusty, muddy, much-traveled public highway. Opposite to it, and immediately on the road, are located the ill-kept farm buildings. How the aromas of the stables and kitchen are to be kept each on its respective side of the road is a question difficult to solve. Here, as in so many cases, the wife showed better training and more commendable pride in her surroundings and her workshop than the husband. She may coax him some day to set a 
few trees, which may serve in part to hide his workshop on the other side. There are many things about this farm house which are commendable, and the only wonder is that so few mistakes were made in planning it. Farmers' wives must have a sort of natural intuition; how else can the fewness of their mistakes be explained, for they have seldom received the slightest instruction along the lines of house-building. True, the tower on the corner is expensive and inappropriate, but if the house had an appropriate setting of trees and shrubs it might be beautiful.

The farm house should have one large bed-room on the first floor, a well appointed kitchen and living room. When the size,

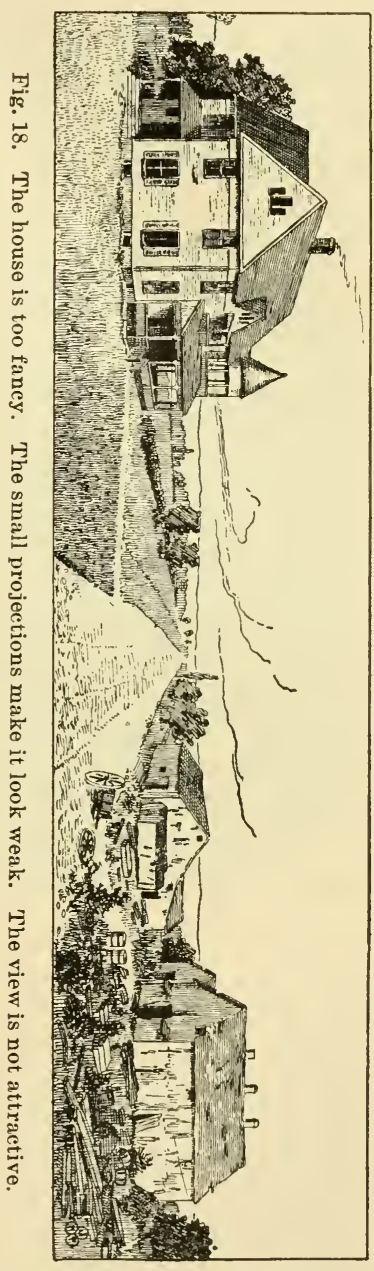
number, and arrangement of the other rooms are 
fixed, the lines which bound the outside of the rooms will not, of necessity, always coincide with the rectangular lines. On one side the house may extend slightly over, on another fall short of the lines which bound the rectangle. Does the rectangle embody fitness and beauty? If the manufactured things by which we are surrounded are noted, it will be seen how many of them are rectangular. The book, the sheet of paper, the pamphlet, the photograph, the picture frame on the wall, the rug on the floor, the writing case, the chiffonier, the trunk, and thousands of objects of use and beauty naturally take the rectangular form: then why not the house? Man constructs along the lines of acute, obtuse, and right angles unless there are specific reasons for adopting curves, while nature's modes adhere closely to circular and curved outlines.

A front view of a substantial, appropriate house fronting to the west is shown in Fig. 19. It is the house of which a rear view is shown in Fig. 16. The wide, projecting eaves, the simple roof over the second-story windows, and the plain veranda, all protect the windows from storm and the glaring afternoon sun. The eavetrough near the edge of the roof serves to relieve the plainness of the projecting roof, which really has no cornice. The side and ends of some of the rafters are seen, and no attempt has been 
made to box them in. The treatment is dignified, plain, inexpensive, and suitable,-therefore it is beautiful. The planting at the left is too thick for ${ }^{\circ}$ any but a dry climate. A lofty

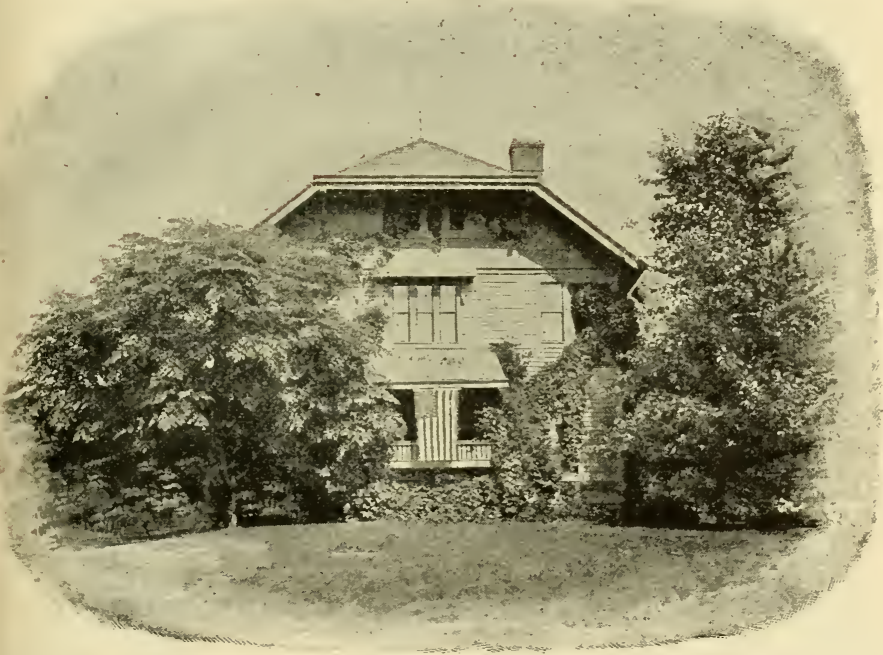

Fig 19. A dignified, restful, economical house.

elm tree would serve better for shading the veranda in the late afternoon, and permit of better air drainage. The trees shown are deciduous, and therefore cannot form an ideal winter windbreak. If they were evergreens they would be entirely too close to the house. The mournful sighing of evergreen trees in the bleak November winds does not promote cheerfulness. 
Four college buildings are shown in Figs. 20, 21, 23, and 24. School buildings can hardly be said to be a part of the farm lay-out, but they will serve quite as well as farm buildings to

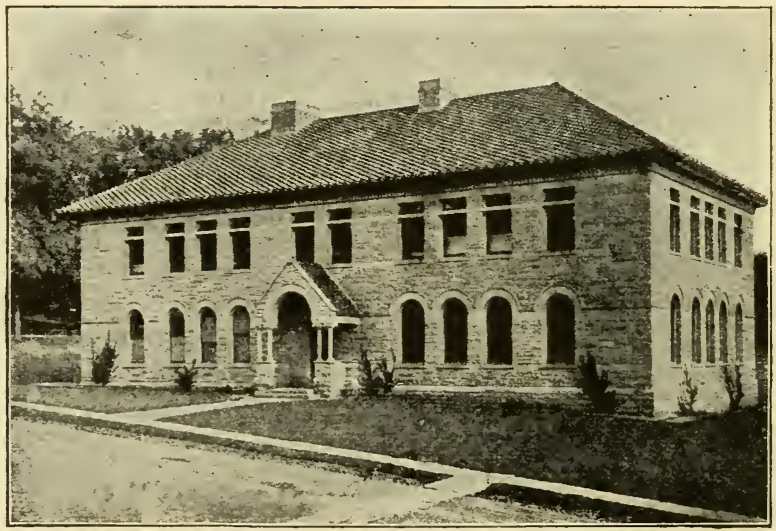

Fig. 20. University building,- -gray stone and tile roof.

educate the taste and to train the eye and the judgment. The reader will see at once which two of these buildings are most dignified and pleasing.

In the schools, the people of the rural districts have had no instruction which would lead them to carefully observe and compare buildings of any kind; and hence, with but rare exceptions, they are ill-qualified to make an intelligent study of them. They are totally unprepared to grasp the fundamental principles which should 
govern the erection of structures on the farm, and totally ignorant of the principles to be observed when large public buildings are planned and erected. Fortunately or unfortunately, some farmers will be called upon to judge of the plans for school and other public buildings. The plans for a president's house and an expensive college building were submitted to a board of thirteen trustees of a flourishing agricultural college. Ten of these trustees were farmers of more than local reputation. I forbear giving illustrations of the results: suffice

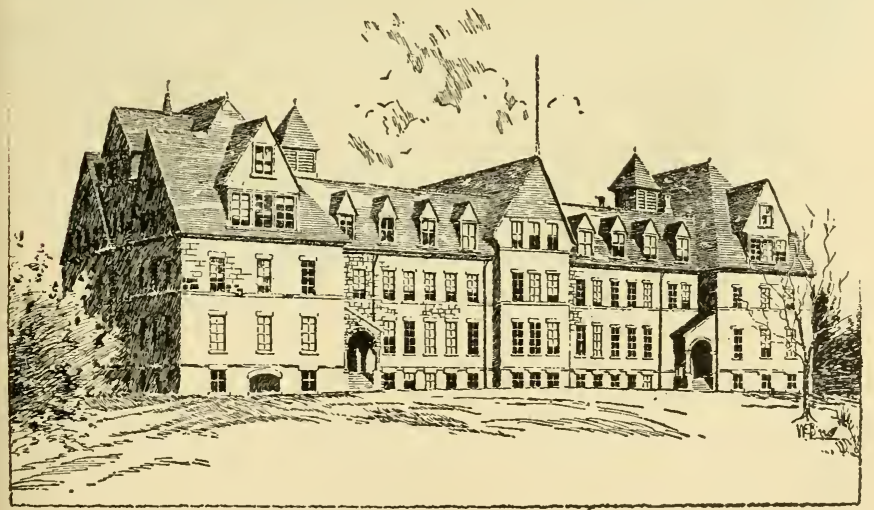

Fig. 21. University building,-red brick and slate roof.

it to say, that happily the house fell down before it was roofed in.

A school building for the higher education should be light and airy; but light does not 
enter a building freely through narrow windows placed in thick stone or brick walls. Fig. 22 shows the effect of narrow and wide windows in the lighting of a building. Observe the shadow cast by the wall between the two narrow windows. The sun is directly in front of the windows for but a small part of the day. Usually it enter's at a more or less acute angle,
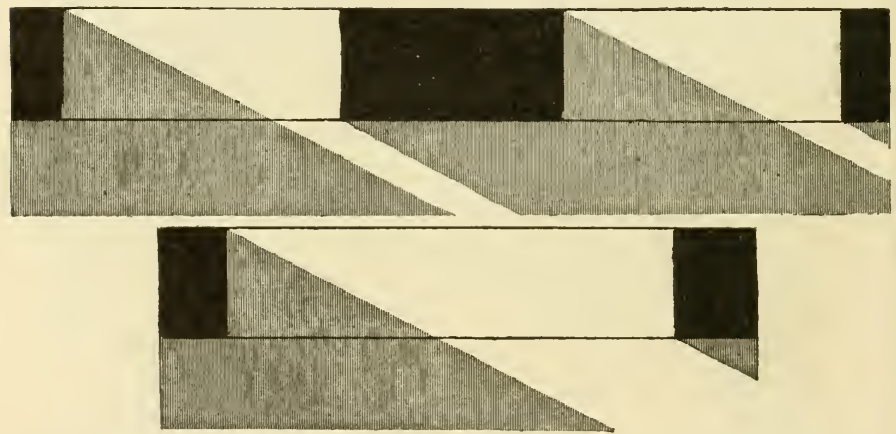

Fig. 22. Showing the greater proportionate amount of light admited by one broad window, as compared with two narrow ones of equal combined opening.

in which case a window three feet wide may be more than twice as efficient in lighting a room as one two feet wide, and a four-foot window three or four times as efficient as one half its width.

Figs. 20, 21, 23, and 24 serve to illustrate some of the fundamental principles which should be observed in constructing expensive public buildings, and they may also serve for com- 
parison, and for educating the eye and the judgment. The knowledge acquired in a study of these buildings may be useful in the plamning and erection of rural homes, for in some respects all buildings should be alike. 'The farmer'

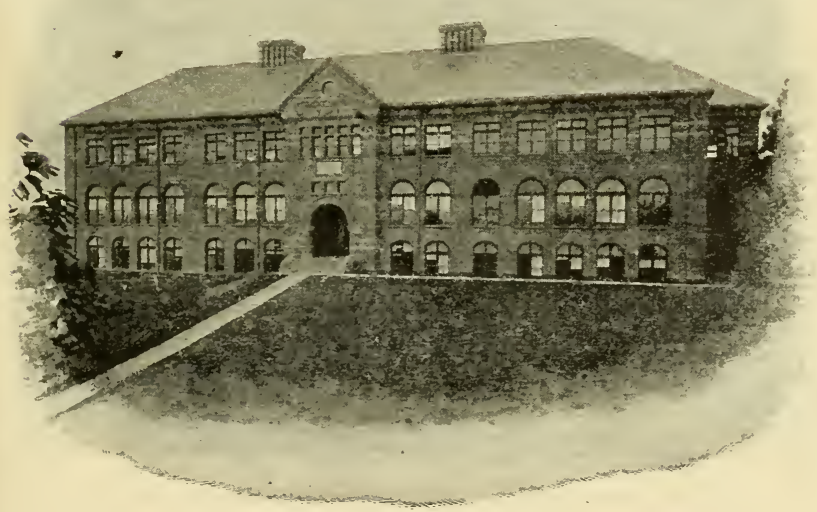

Fig. 23. University laboratories, - red brick and slate roof.

seldom has opportunity to contrast and study large detached buildings in which beauty, dignity, durability, and, above all, utility, are combined, and he seldom plans and erects more than one homestead; therefore, many buildings should be observed, the desirable and undesirable features noted and discussed thoroughly before the erection of a new structure, however 
simple it may be, is begun. It requires no little knowledge to construct in the best manner even a modern chicken house.

The consideration of these four school build-

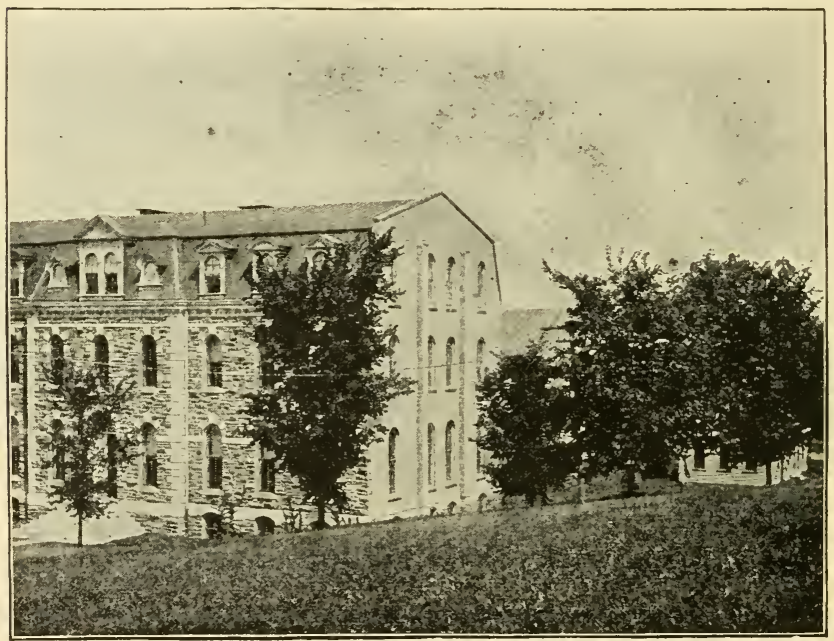

Fig. 24. University building,- gray stone and slate roof.

ings, so different in character, may not be dismissed at once. They are introduced for the purpose of arousing interest and for giving opportunity to study the principles of external construction. The true principles once mastered, their application to rural homes will not be difcult. If Fig. 20 be studied carefully, it will be noticed that the lines are dignified, restful and even beautiful, although the building is con- 
structed on straight lines, with little attempt at ornamentation. This building is sometimes taken for an art gallery, and so it is, for in it is taught the fine art of butter making. Its strong tile roof, ample projection of eaves, and freedom from peaks and valleys give assurance that this building, barring accidents, will stand for centuries with slight repair, and be more beautiful as time tones down and softens the colors.

The building shown in Fig. 21 satisfies neither eye nor judgment. It is a noble building as to size and material, but are not the twenty miniature peaks out of place? It does not have the appearance of a restful school building, but of a mammoth seaside hotel. The many little gables might have been combined into a few large, noble ones, which would have given abundant light and lent dignity and charm to this well built structure. If we now transfer our thought from the large buildings to the brick dwelling house (Fig. 25), we find the same strong lines, the same dignity, and the same durability of roof structure, with a little added ornamentation; as are found in some school buildings. It should have been two-story instead of a story and a half, and the reranda might well have been more ample. This house, too, like the large stone structure (Fig. 20) is 
restful and satisfying. One instinctively sees that the cost of maintenance of this durable structure will be comparatively little. If this house be compared with the one shown in Fig. 26 , it will be easily seen how much more appropriate and beautiful it is. One is built of

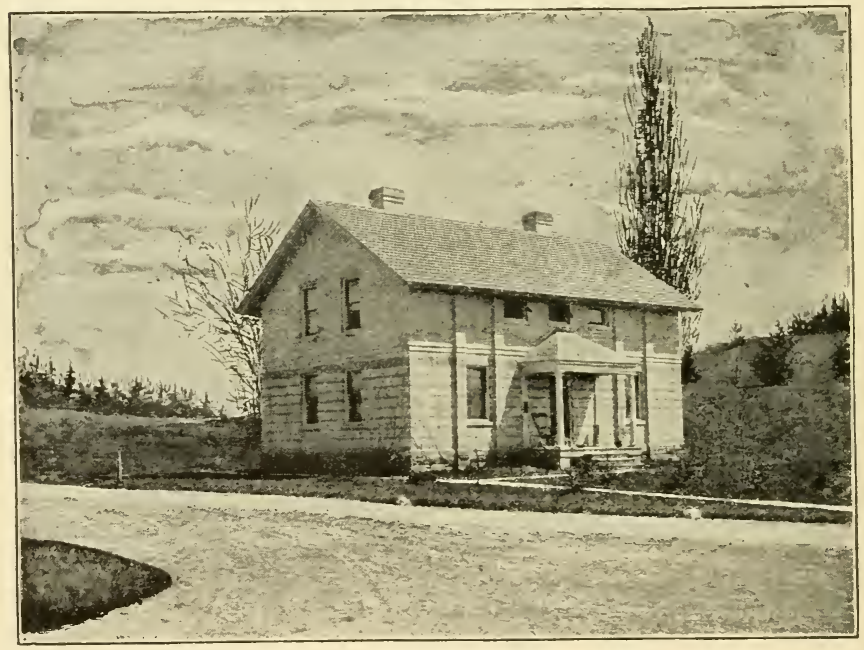

Fig. 25. A simple and attractive little dwelling house.

cream brick and roofed with soft-colored tile; the other is roofed with poor shingles, has a cheap hemlock frame, and is sided with wood, which is covered with gaudy, ready mixed earth paints, which may fade out before the bill for them is paid.

Some day a genius will set forth for the 
farmer, in simple language and illustrations, the fundamental principles which should be followed in the building of rural homes. When that time comes the present children will then be mature and will have been so energized by nature-study work, which is now being intro-

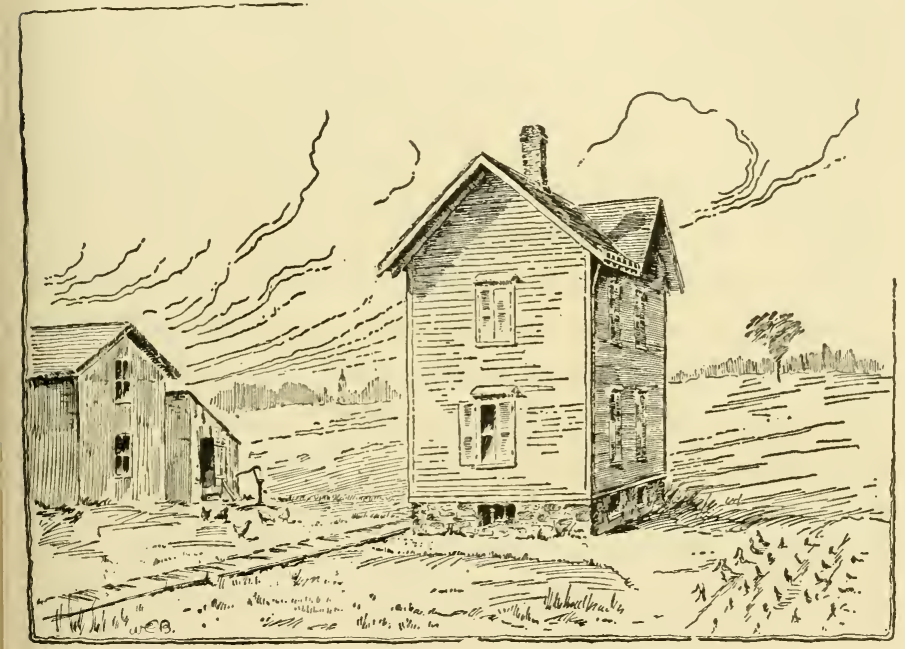

Fig. 26. Another type of dwelling house.

duced so extensively in the schools, as to be able to appreciate and profit by such literature. Some of the tree-embowered farm houses have such a restful look and often embody such true lines of beanty that it seems almost sacrilegious to change them. On the other hand, some of them are so ill adapted to 
farm life, so unhandy and uncomfortable, that radical changes should be made. After the farmer has prospered, he naturally has a desire to build a new house or to transform the old one, not only to secure needed conveniences, but that greater beauty and a more luxurious home may be secured. It is difficult for him to find adequate help to solve the problem if he keeps the cost within reasonable limits. He may know where to begin; he seldom knows where he will end. Usually the first thought should be to preserve the old home, or the greater part of it. The architect is almost certain to advise demolition and the erection of a new house, asserting that the new structure will be no more expensive than the remodeling of the old, which may or may not be true. But he does not always know what is best, as he is usually unfamiliar with the farmer's' needs and traditions. Sacred associations usually cluster round the old farm house; every room and door and window may be associated with some epoch in life's history. 'Throngh yonder door came the happy bride a half century ago; in yonder room the children were born;-erery nook and corner has some tale to tell, some happy assoriation. We cross oceans and mountains to view the birthplaces and homes (which happily sometimes are pre- 
served and held sacred) of a Burns and a Shąkespeare. Then is it not well to preserve the farm houses, where possibly are the birthplaces of many "Cromwells guiltless of their country's blood."

The first thought, then, should be to save and improve the old house, not to destroy it. But most of these farm houses are either too low or too high: that is, they are neither onenor two-storied, but a story and a half. A two-story wing may often be placed either at the front or side, and may serve to give dignity to the house; or a lower room or two, a few comfortable chambers, and an entrance hall or vestibule may be added. Such addition would make it possible to remove the low, flat-roofed, leaky kitchen to more appropriate quarters. The formerly unused parlor might be transformed into a living-room, the former livingroom into a dining-room, and the old diningroom into a kitchen. The details by which this evolution is made must, of necessity, be worked out by those who are to occupy the house. That home is enjoyed best which is planned by those who have to pay the bills; therefore, I shall not go into detail of arrangement. My object will have been accomplished if I succeed in creating a greater respect and love for the houses of our ancestors, and shall 
have stayed the hand of the iconoclast. Any one can destroy, but few can create.

So reasoned the college graduate on his return to the old homestead. The old house (Fig. 27) was improved by making slight additions and some minor changes. Even the green window blinds and the white siding were not disturbed, only brightened by the use of oldfashioned, mnadulterated paints. The major effort was along the line of improving the live stock and making the acres more productive, soon resulting in surplus funds, which were used to erect the large and commodious barn. Simultaneously with the barn came the icehouse, and the windmill for pumping water. The observant passer-by instinctively knows that here are all the outward indications of morality, intelligence, and a rational and progressive system of agriculture. If the family be judged by what is seen in this picture of the farm above ground, the conclusion must be reached that here is a true home.

How different the impression is when we look through the open roadside gate in the next picture (Fig. 28)! Lack of intelligent purpose and of neatness and thrift is witten upon every structure, and is especially shown by the want of any logical plan in the arrangement of the numerous small structures. The house, which 


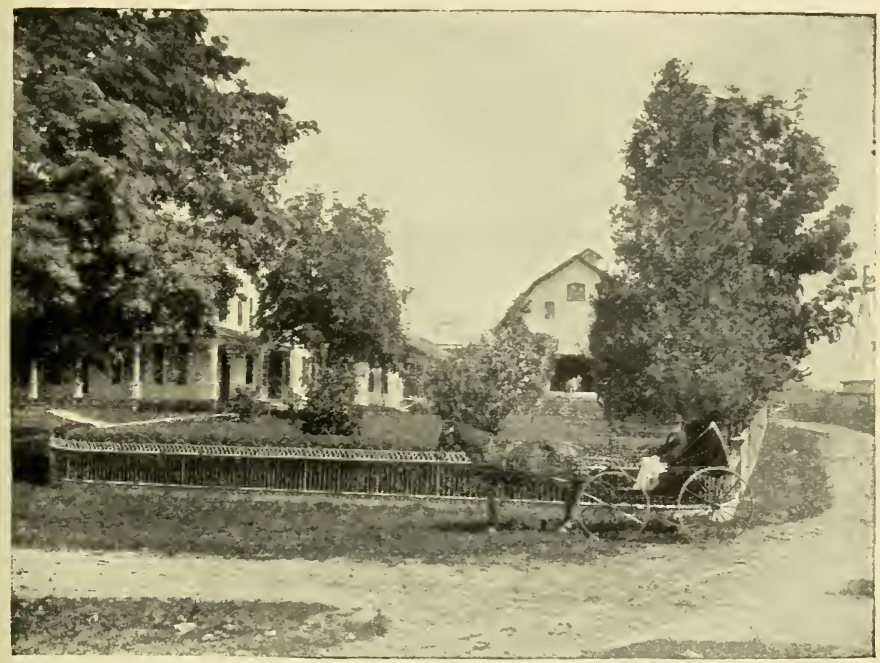

Fig. 27. The old homestead.

\section{गiा}

$$
\text { 信: }
$$

$$
\text { 중 }
$$


stands just to the right of the beautiful tree, is modern in many respects, but the front is supported by numerous Grecian columns nearly twenty feet long, as inappropriate and as useless for a farm-house as is a coon's tail on a lady's hat.

Instinctively we judge people at first sight, and largely by the clothes they wear and the manner of wearing them. So we judge, and often very accurately, of families by the houses which shelter them and the objects which smround them. One can easily tell much of the character of a man by the style and tip of his hat. What noble deeds, what lofty aspirations in this lay and age of plenty and opportunity, should we expect to have birth and fruition in the house shown in illustration Fig. 29! This building is not located in the comntry, lunt in the suburlis of a small, prosperous inland city. Unfortunately, this village is mulike many beautiful country villages and small cities in western New York in which there are no poor people. What a depressing effect this building must have on the well hred comntry lad who passes it weekly on his journey to and from the post office!

But how easy to go from one extreme to the other! Too many farm houses stand alone, murelieved by noble trees or by modest plant- 
ing of apropriate shrubluery, looking in the distance at the setting sun like lofty, whitewashed sepulchres. On the other hand, the house may be made dark and damp by overplanting. The honse shown in Fig. 30 is a comfortable, fairly attractive stone structure, but is made gloomy and damp by the superabun-

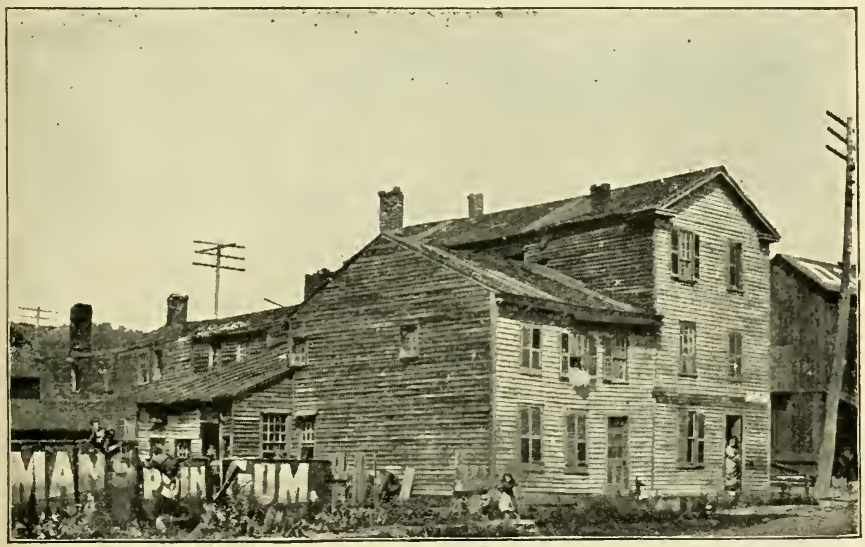

Fig. 29. Environment often makes the man.

dance of evergreen and deciduous trees which fill all the space, barely thirty feet, between the house and the highway.

The church, as well as the farm house, is or should be the home of the farmer; but the church, like the individual, may become proud, in which case the old meeting-house is demolished and replaced by a modern new one, 
which may serve for a time to stimulate laggards and appear to take the place of changed purposes in life. But the debt saddled on the

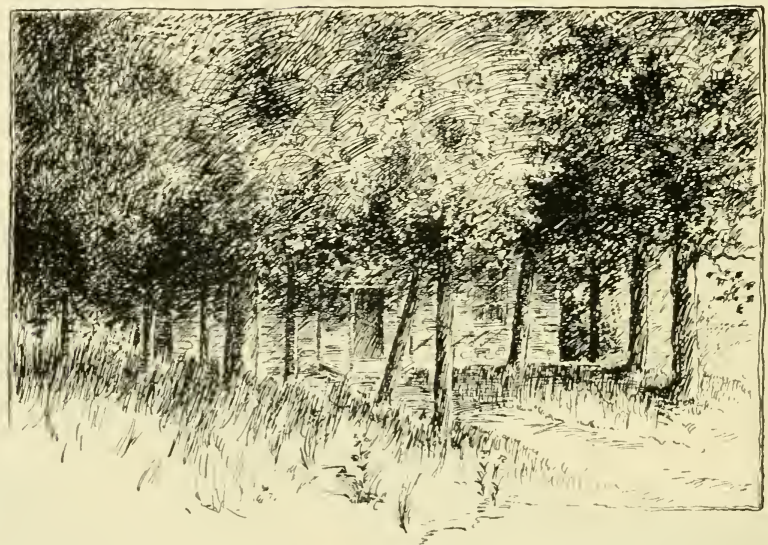

Fig. 30. Buried in trees. The opposite extreme from Fig. 26.

congregation tends to drive the church-goers to the rear seats and eventually ont of doors. I have sometimes thought that a country church could not well be too small. Man is a gregarious animal, and does not enjoy church-going when the seats are but partially occupied.

The plain, substantial stone church shown in Fig. 31 is located in a sparsely settled district on the windy prairies of Kansas. It is certainly most appropriate and fits its environment; all it lacks to make it beantiful is a suitable setting of trees and shrublery. It would then serve as 
a reminder of "God's first temple not made with hands," and not of one made with a jig-saw.

"It is a plain, rugged, austere structure, like the men who built it, and any proposal to modernize it would be received with disfaror; for it means more to the people than merely a church building - it is a sacred possession that is a part of their life," and it is an appropriate monument to the sturdy religious character of the pioneers who stood in the forefront as a wall guarding human rights and liberties in those storm y days of the past. The country church should be as truly a part of the farm structure as are the house and barn, located on land held in fee simple.

\section{The school-}

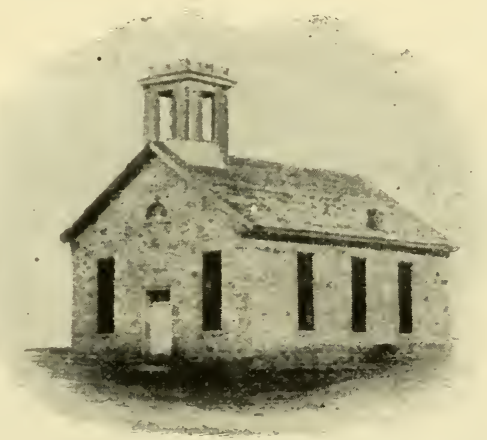

Fig. 31. A plain, substantiai stone ehurch.

house also, as well as the church, should form a part of the farm above ground. We sometimes build parlors for the pictures, and palaces for the horses and cattle, and neglect the school-house. A city of 12,000 inhabitants 


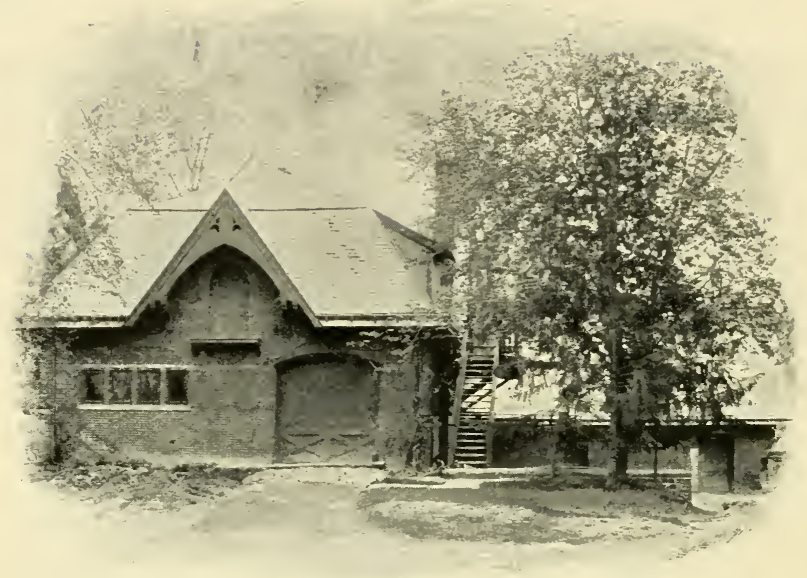

Fig. 32. Where horses are kept.

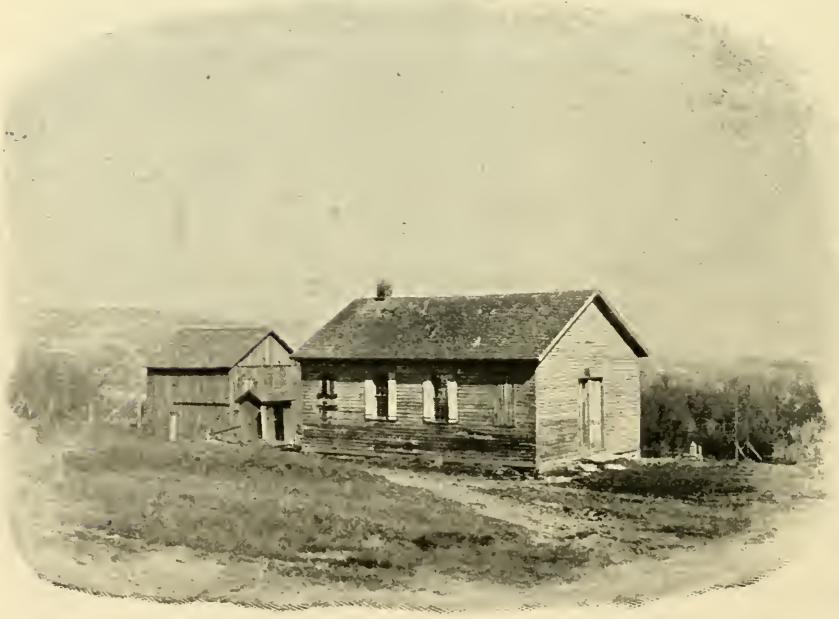

Fig. 33. Where boys and grrls are taught. 
in central New York has many expensive stables, some of them works of art. The barn shown in Fig. 32 is not more than half a mile from the school-house shown in Fig. 33. The beautiful stable might serve as a well appointed dwelling house by making a few minor changes. While such buildings are being constructed, the country school-house, the pride of the American, is left to fall into decay; or, if rebuilt, it is located too often on a little scrap of land which may be almost worthless, as though land in America were the most precious of all our inheritance. This schoolhouse is designed to provide accommodations for both farm and city children living in the suburbs. The school-house has not a tree for shade nor a shrub to admire, situated on the commons among weeds and rocks, provided with one dilapidated outhouse unscreened by fence or tree or vine or shrub, while the stable is surrounded with rare trees and shrubs artistically arranged and a smoothly shaven lawn. Are horses and cattle worth more than boys and girls ?

To leave the reader to infer that all schoolhouses are like the one shown would be misleading. A more pleasing illustration is presented in Fig. 34. Here the meeting-house, the school-house, and a bit of the farm are 
shown in juxtaposition, as they were found at the meeting of the roads in a shady grove. Since moral character should be the foundation upon which to symmetrically build intelligence and industry, the church may be treated first. While taking the photograph, I was struck by the inexpensive character of the meeting-house. The outside covering was of plain, matched, vertical boards, but they were kept well painted and therefore looked neat, and the seats were entirely comfortable. I judge that here true, practical religion finds a congenial home, for a long line of comfortable sheds were being built to house the horses during the hours of derotion. Then, too, the sheds will serve a doubly humane purpose, for where the pupils live long distances from the school the horse driven in the morning will have comfortable quarters until the school closes in the erening. A public water-trough near by, kept full from a spring, gave evidence that this little church and the school-house were potent factors in promoting civilization. To the right is seen a lad plowing. Here, then, in this picture is represented the three great corner-stones of civilization upon which to build a symmetrical, beautiful superstructure. To build on either one alone is to insure disappointment; when life is grounded on all three the result is practical religion and 
intelligence eventuating in a better understanding of the complex soil and the interrelations of nature's modes of action. It means steady and effective employment, the abandomment of nomadic life, and in lieu thereof a permanent home and an abundant supply of the necessaries and comforts of life. The Bible, the

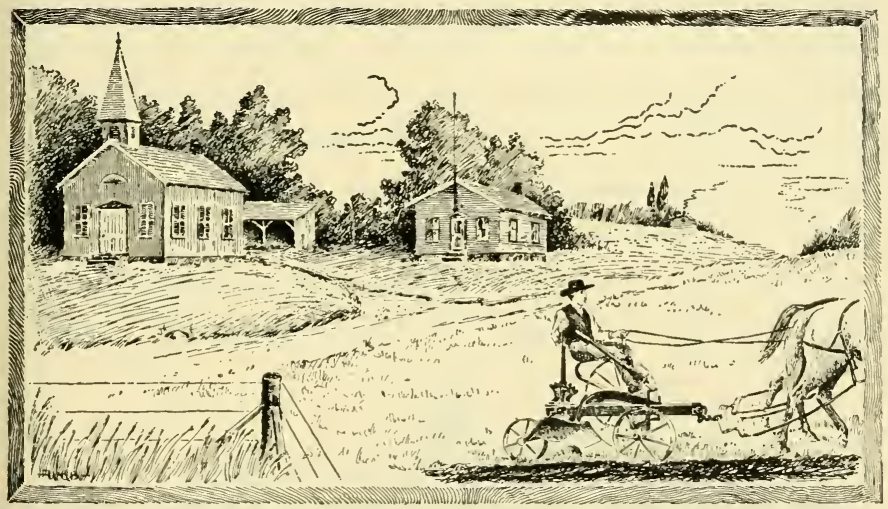

Fig. 34. School house and church at the corners.

school book, and the plow should all be engraven and intertwined in our moder'n civilization.

So far the general characteristics, fitness, durability and beauty of the country farm house have been discussed and illustrated, together with such public buildings as are directly related to rural life. But having discussed the size, best proportions, and most suitable materials for the house, and having put them into 
visible form, the building may be made hideous and nunecessarily expensive by careless or ignorant treatment of external details.

Most of the farmers who now occupy the country west of the Alleghanies came from the east and brought with them a varied assortment of styles of architecture inherited from the many European countries from which they or their ancestors came. These people, though of limited means, had pride and tenacity of purpose, and they could not easily change to the plain and appropriate exterior treatment of the farm house. This inheritance and persistence, as shown in the farm houses of the middle states, is fitly illustrated by the expensive and heary

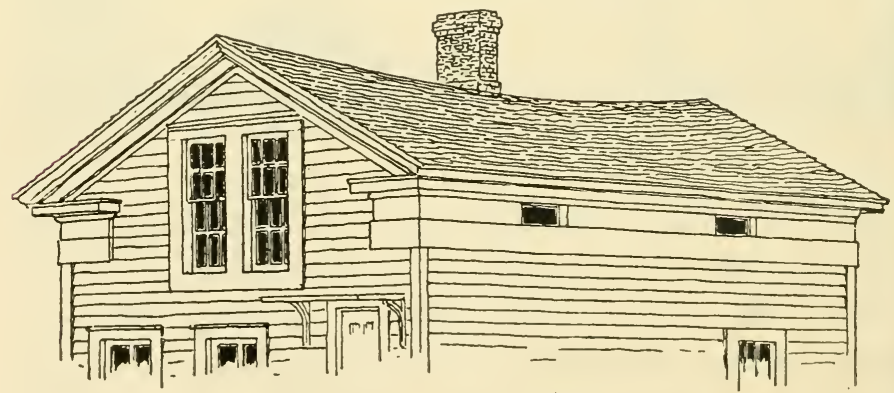

Fig. 35. The sway-back house.

return cornice, the massive columms, and the complicated and ornate entablatures which are supposed to adorn an otherwise plain house. 
I have said that there is no place for the story-and-a-half house. Here is shown (Fig. $35)$ the results of two serious mistakes; viz.,

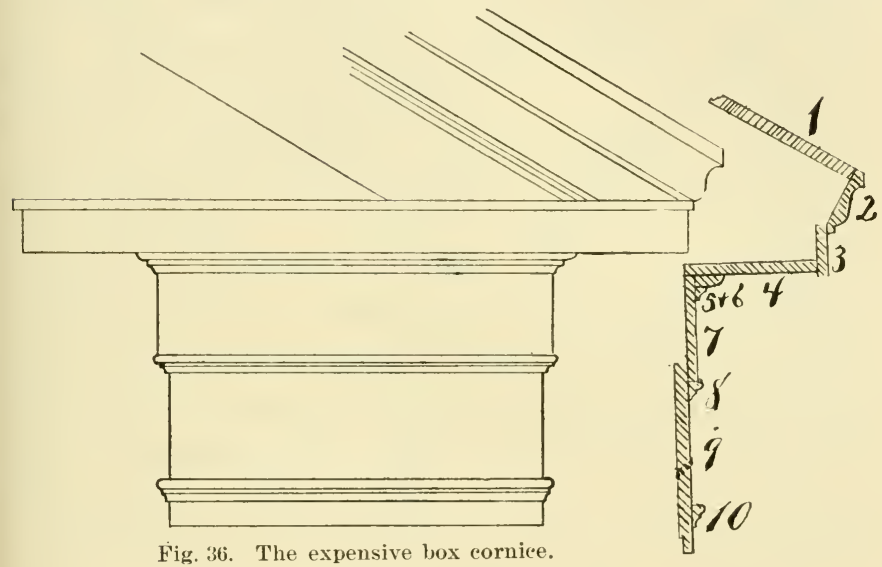

an effort to build a cheap frame of such a form that it is almost impossible to tie the building together, with the result that the roof is in danger of collapsing; and the attempt to beautify this cheap structure by orer-heary, complicated cornices. An enlarged detailed drawing of a typical return cornice is shown in Fig. 36. On the right is shown a cross-section outline of the members of the cornice. There are ten of them. The mouldings are now "stuck" by machinery, but these were marle by hand, and 10 and $S$ were formed of two pieces 
each, making twelve members in all. The infinite pains and labor in preparing the material and placing it cannot be realized

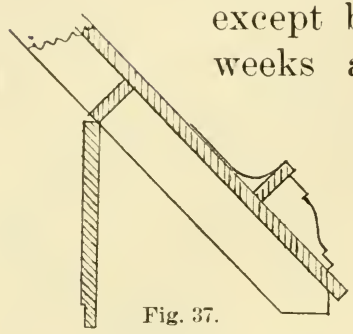

A plain and durable cornice.

by a carpenter who has spent and months in sawing out: in planing and "sticking," and mitering such an elaborate system of useless ornamentation. Compare this with the cornice, or rather projection, of a house (Fig. 19) which cost $\$ 6,000$. Fig. 36 shows a projecting eave of scarcely one foot. The next illustration (Fig. 37) shows one of nearly two feet. The latter is far superior to the former in that it is quite as beautiful, is inexpensive, and protects the external paint and woodwork far more than does the former. The piece at the top of the rafter serves to cover the projecting cornice, and as a roofboard as well, and gives opportunity to place the eave trough well outside, which prevents damage to the house should it ever leak. The frieze board is simple and serves its purpose well. It has taken a long time to learn that a wooden roof which is at least one-third pitrh is far more durable than the flat roof shown in Fig. 38. Here the return cornice is carried across the entire end of the house, and 
the gable is ceiled with plain matched boards, both likely to leak and to rapidly become paintless.

Many veranda and porch floors and outside doors have no roof over them, or other protection. This is poor economy. It would be better to reduce the cornice to the ferrest possible members, if it were necessary to do so, in order to secure means to roof the veranda, which, unprotected, decays rapidly. Or the money expender on the cornice, which results in neither use nor beauty, might well suffice for the building of an additional room, or to provide many conveniences, such as hot and cold water, storm sash, and window screens.

When the farmer reached the fertile, treeless

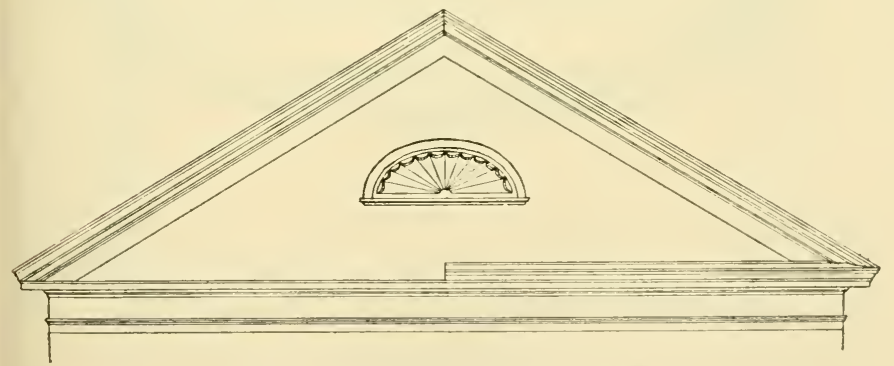

Fig. 38. The old-time gable end cornice.

prairies he was compelled to economize in lumber. Some genius soon discorered that the best and most scientific method of constructing 
the frame of a house was along the lines of ship construction (Fig. 39): that is, ribs, joined to a sill or sills, encircling the entire structure and placed at equal distances apart. Two keels or sills joined together by joists, straight

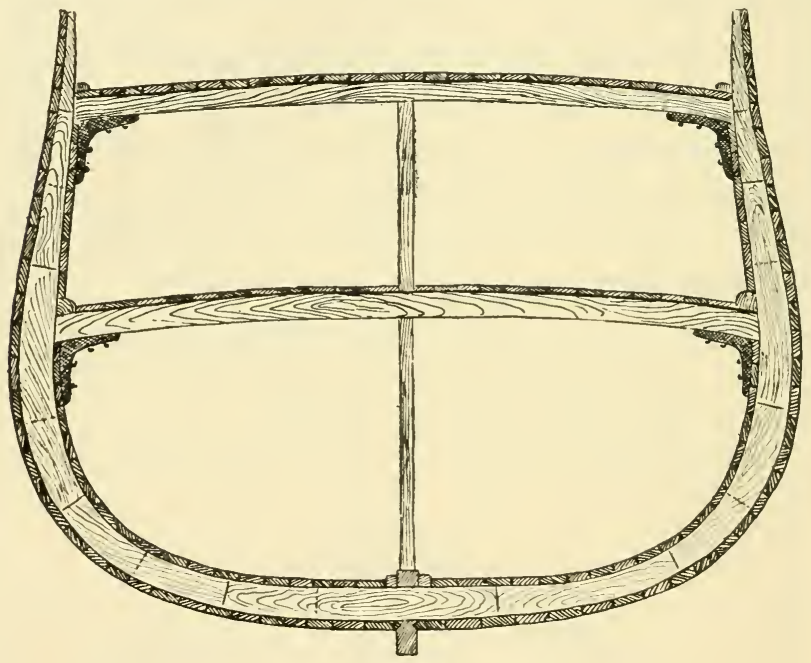

Fig. 39. Framework of a ship.

ribs-joists - instead of curved ones, a roof instead of a deck, and the balloon frame (Fig. $40)$ - the best of all frames when properly constructed, - was invented. Unwittingly the ship construction, slightly modified, was adopted. In this frame the westerner departed radically from the style of his ancestors, but he could not be satisfied with a plain oversail projection. 
He could not afford the heavy box cornice. Having succeeded so well on the frame, he set about inventing a new style of decoration for

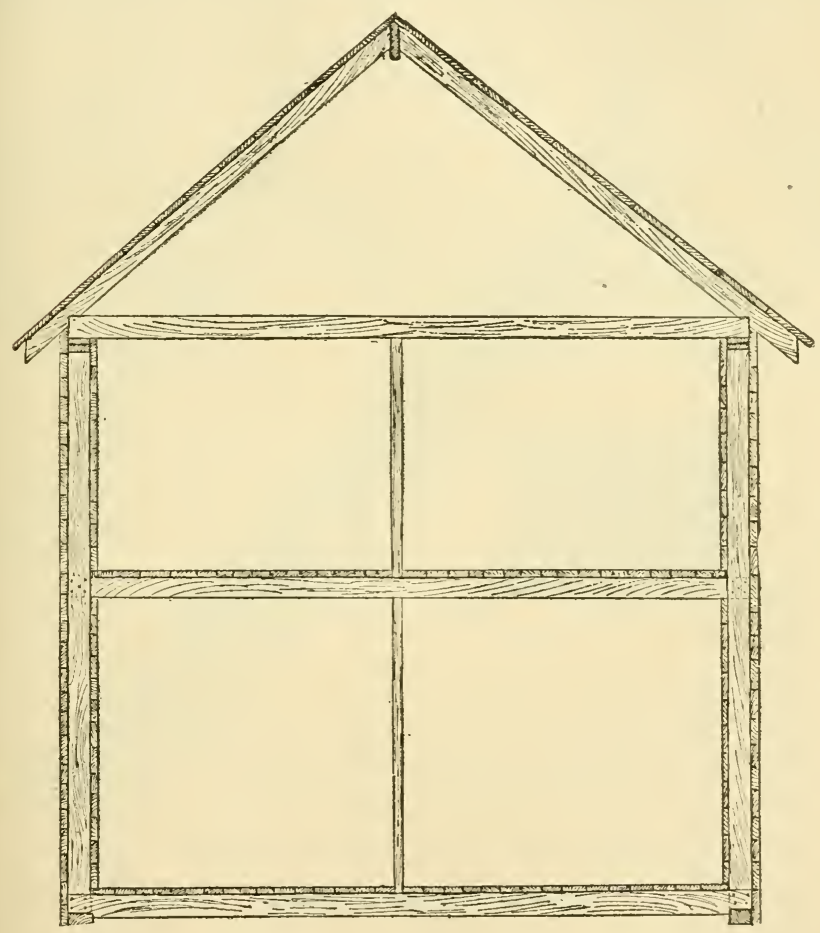

Fig. 40. The balloon frame.

the projecting eaves, but the cornice was not a success. The decorations shown in Figs. 41 and 42 serve to make hideous many a cheap dry-goods-box house, which blisters and cracks 
in the hot prairie winds. These houses sometimes receive no paint or one coat, or at most two, and in a few years, what with storm and sun, mischierous boys and wind cracks, this

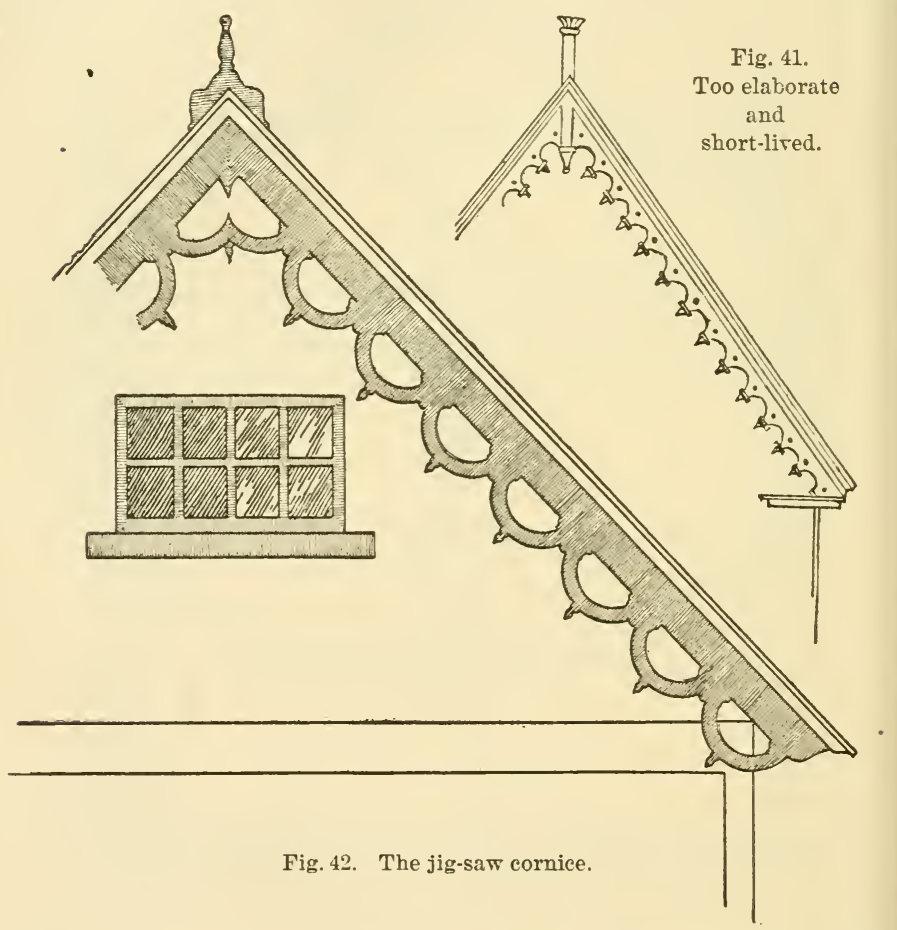

ginger-bread, dog-eared cornice, made of inch lumber by the use of scroll saw, looks as dilapidated as a college boy after a cane-rush. The thought of permanent beauty, as well as 
economy and usefulness, should enter into the plans of a house. But what is beauty? I am well aware that many of my readers will not agree with me, for

"The standard of beauty ofttimes it doth vary: Two pretty girls are Eliza and Mary."

They may be very unlike, yet both beautiful. From the farmer's standpoint it may be said that the chief characteristics of beauty are fitness, naturalness and simplicity. 


\section{CHAPTER VIII}

BUILDING THE HOUSE-GENERAL LAY-OUT

THE reader will understand that no attempt is made to treat this subject in detail $\mathrm{nor}^{\circ}$ strictly from the architect's vierpoint. A casual observation will make it self-evident that the structures on farms have received little attention as to beauty of form, economy of construction, or adaptation of means to ends. Like many others, I have noted all this and have made a somewhat careful study of the causes which usually have produced this want of harmony, durability, adaptability and economy in the construction of rural homesteads.

The many illustrations of detail are designed to emphasize underlying principles. Principles are always the same: details may be varied to suit conditions. While the numerous illustrations are meant to explain the details, it is believed that they will also give help to a large part of the rural population who have had little opportunity to secure any adequate instruction in the art and science of home building. Usually the cellar would better be extended 
under the entire house, although it is neither wise nor healthy to store large quantities of material in it which, if not cared for, may decay and vitiate the air in the rooms above. If the cellar be properly constructed there is no objection to storing family supplies of fruit

Fig. 43. Cellar under the upright only.

and vegetables for the winter in this partly underground room. Large quantities of vegetables held for future sale should not find storage in the house cellar. Now that the floors of houses are made tight, often double with paper between, and carpets or l'ugs to cover them, the cold no longer enters the cellar through the floor. The cellar wall may therefore extend upwards on three sides, well above ground, that opportunity may be given for the introduction of light and air. With only single-glazed cellar windows, no building paper, and floors and boarding of unseasoned lumber, the pioneer was compelled to place the cellar well under ground, or bank the walls with manure if the winter's supply of regetables was to be made secure. 
A common form of the foundation for farm houses is shown in Fig. 43-a main structure, reinforced by a wing which, in most cases, has no cellar under it. Fig. 44 shows the cellar under the whole structure. If the walls of the unexcavated wing are placed $3 \frac{1}{2}$ feet below ground, as they should be in a cold climate, and extend 2 feet above ground, it will take more stone to construct

Fig. 44. Cellar under the entire house.

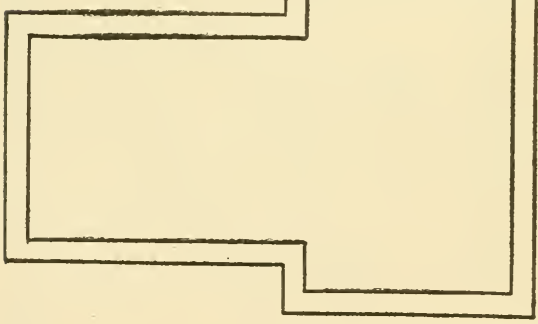

the foundation walls of the house with a cellar under only a part than when it extends under the entire structure. The stone saved by leaving out the wall between the two sections of the house will more than suffice for building the walls of the wing to their full height. In the latter case, it rould cost slightly more for excavation than in the former. Since cellars, when appropriately used, are in some respects the most useful and cheapest rooms in the structure, there is no economy in not placing them under the entire house. A cellar may be divided by 4 -inch brick walls into various rooms, corresponding in 
shape to those abore, thereby securing supports for the partitions in the superstructure, and also separate compartments, in order that the vegetables, fruit, milk, and furnace may be separate one from the other.

To prevent rats from entering the cellar under the walls, either one of two methods may be adopted. A footing-course projecting beyond the outside of

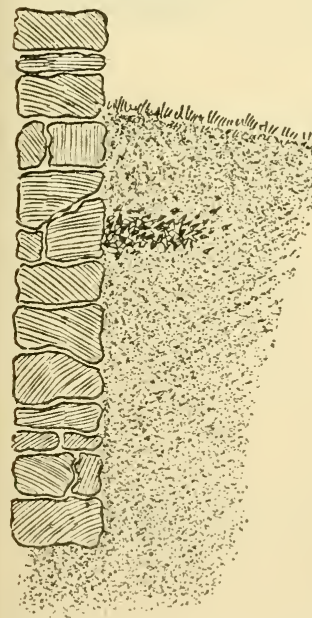

Fig. 46. Showing a layer of material to stop rermin. the wall arrests the rodents, for having dug down to it they have not sufficient

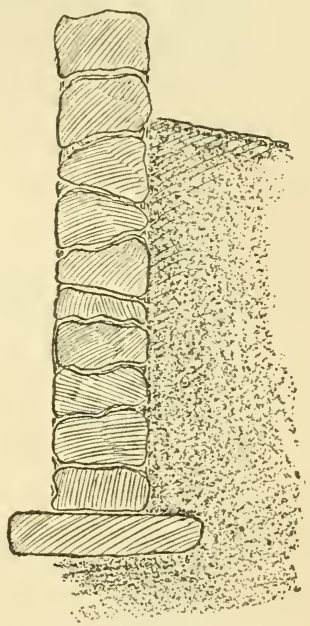
intelligence to dig around the footing-course (Fig. 45). Or the desired result may be accomplished by placing a thin layer of refuse broken glass against the outside of the wall two to three feet from the surface of the ground (Fig. 46). Cellars would be much improved if they had higher ceilings. At least 7 feet should be allowed 
between the cellar floor and the under side of the overhead joists. All cellars should have concrete floors and plastered ceilings, for both warmth and cleanliness. In an extremely rigorous climate, the upper angle of the wall should be lathed and plastered as shown in Fig. 47.

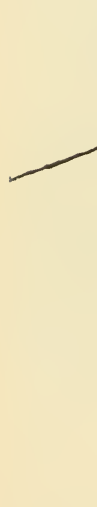

- WINDOW IM CELLLAR FROM IMSIDE
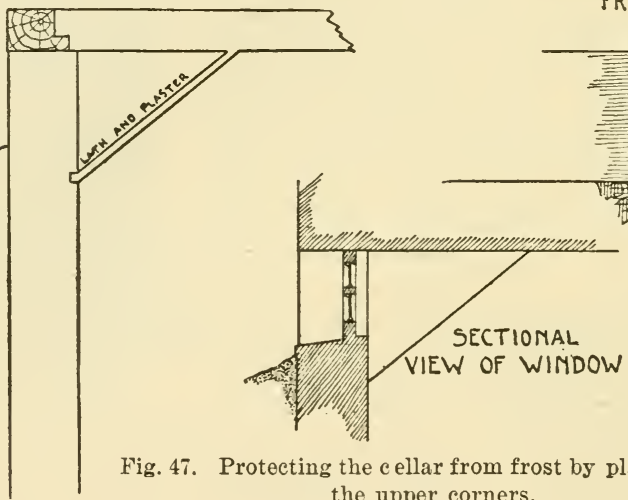

Fig. 47. Protecting the e ellar from frost by plastering across the upper corners.

If the front cellar wall and the greater part of the side walls extend 2 to 3 feet above the earth, a good sized window (which may be single- or double-glazed) can be secured. The rear walls should extend not more than one foot above ground. If the earth slopes rearward, then grade up to the wall until not more than two steps will be necessary to reach the kitchen floor ; it is easier to climb a gentle ascent than steps. The front steps are used but 
cellar free from water by drainage or by backing the wall with loose rubble stone, or by both (Fig. 51).

\section{BUILDING THE FOUNDATIONS}

The walls should be placed below the frost line and have fairly broad

Fig. 51.

A rubble stone backing and a drain at the bot. tom.

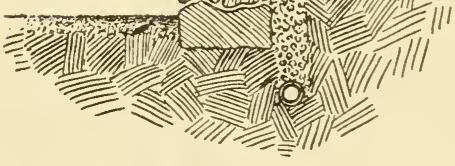
bases, standing on naturally or artificially -

this

$d r$ a in ed earth. Perhaps no part of the house structure receives so little attention as do the foundation walls; therefore, I shall enter somewhat into the details of construction. Bricks which have been recently burned and those which do not contain considerable quantities of moisture should be thoroughly wet before they are placed in the wall. If the mortar sets too quickly by reason of the dryness of the bricks, a strong wall cannot be secured, horrever good the mortar may be in which they are laid.

The foundation walls for most houses, how- 
ever, are made of stones laid in mortar composed of lime or cement, or a mixture of the two, and sand. A large proportion of all the sand used for foundation work is markedly inferior, and the mortar is usually very imperfectly mixed. If water lime is used with the sand it is frequently old, and if old, inferior.

Even the cements deteriorate somewhat with age, and the common stone lime is often used after it is partially or entirely air-slaked. If the binding material be inferior and the sand have quantities of fine earth or vegetable matter mixed with it, it will be seen how impossible it is to secure a strong and binding mortar. Even if fresh lime and sharp sand are used, in accordance with the usual specifications in building contracts, the mortar bond may still be weak by reason of careless or imperfect mixing. All mortar, even that used for laying stones and bricks, should be mixed until a lime film surrounds every particle of sand. Plastering the outside of the wall below the grade line and pointing the wall above cannot make a firm, good wall out of one which has been carelessly laid or one bedded in inferior mortar.

Chimneys may provide for one or more flues. Better draft is likely to be secured when separate flues are provided for each stove or heater than when one flue serves for two or more 
stoves. The diagram, Fig. 52, shows three flues in one stack or chimney. One is for the furnace, another for the fireplace, and another for the laundry stove.

All chimneys should have broad footing courses, which should rest on solid earth to

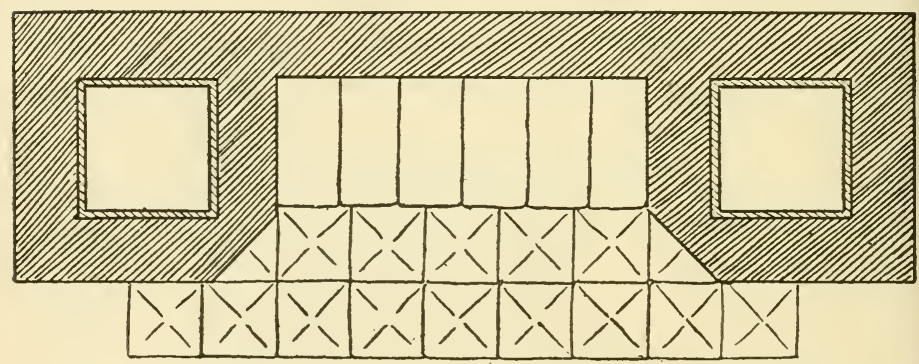

Fig. 52. Three flues in the chimney, one of them leading from a fire-place.

prevent settling. They should not be supported by means of brackets (Fig. 53) or on the tops of small cupboards attached to the wall. Chimney walls of only 4 -inch thickness are not safe; if they be double, or 8 inches thick, the number of bricks required are increased by more than 100 per cent, and the cost of the foundation is also increased. The heary walls are objectionable by reason of added weight and cost, and because of the room they occupy. The introduction of fire-clay chimney lining makes it possible to construct safe chimneys with 4 -inch walls. Then, too, the lining costs rather less 
than the extra course of brick, and the completed flue is smooth and of uniform dimensions on the inside.

The openings made in the frame for the chimney are often too small, in which case the chimney is likely to be "hung" on either the joists or rafters. There should be a clear space between the woodwork and chimney. If the opening in the frame is too small, the mason will be tempted to clip the brick where the chimney passes by the wood and then restore the chimney to its full size when the obstruction is passed. This results in hanging the chimney on some member of the frame. Should the foun-

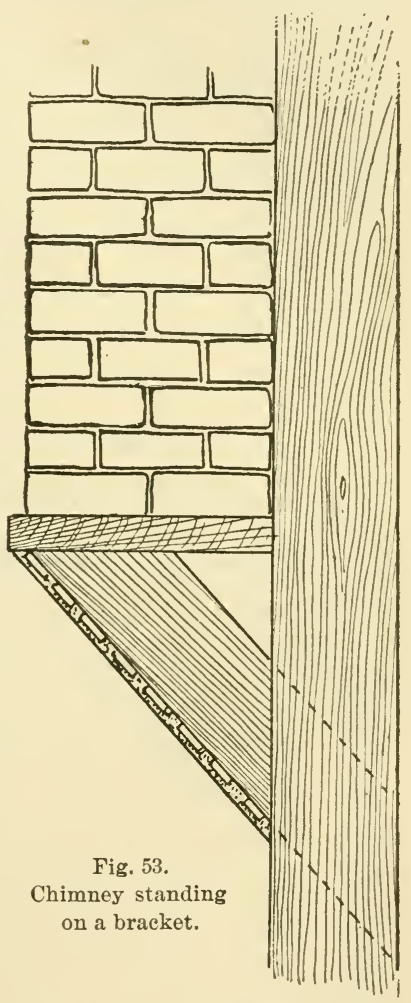
dation settle, the wall may part and sparks may then easily reach the dry wood in the room or at the roof of the house.

It is believed that the farmer, after reading these lines, may secure a good wall and one 
which fulfils the specifications, if he watches the work carefully as it progresses. If he does, he will have a much better wall than the average. Since the material and the kind of work desired vary so widely, it is not wise to lay down any fast rule for the proportions of the binding material and sand which may be used. It may be said, however, that the proportions vary from 1 of lime or cement to 2 of sand, to 1 of the former and 6 of the latter.

\section{WOODEN HOUSES - THE FRAME}

Almost any variety of rood will suffice for the frame of the house, provided it does not twist and spring out of shape too much before or after it is put into the building. Since the sills are to be placed on solid, continuous walls, they need not be large. The only objection to box and small sills is that they may allow too easy access of air and rodents from the walls of the rooms to the cellar, and vice versa, unless the spaces above the sills and between the studding are bricked in as high as the top of the first tier of joists. A rough floor laid before the upright studding is placed is shown in Fig. 54 . This first floor should be laid diagonally, for the one which is laid immediately upon it should not be placed either parallel or at right angles 
to the boards of the first floor, or parallel with the joists. A little reflection will reveal the reasons for all this.

Joists should be bridged. Fig. 55 shows the more common method of bridging. The joists

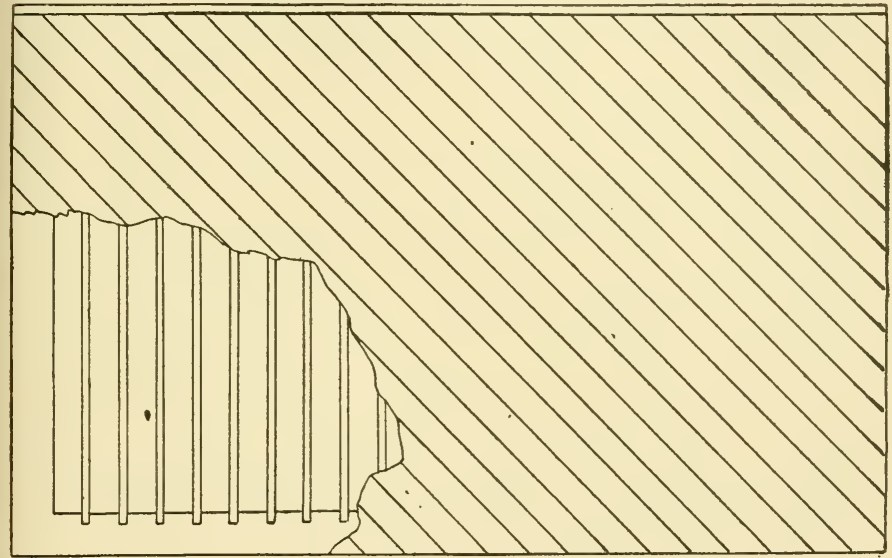

Fig. 54. The rough floor laid before the studding is erected.

may be $2 \times 8$ in small, inexpensive houses, and $2 \times 10$ or $2 \times 12$ in large ones, bridged once in a 12-foot span, twice in a 16-, and three times in an 18- or 20 -foot span. The bridging is of the utmost importance and should never be omitted, as it serves to strengthen the floor joints and prevents the disagreeable trembling of the floors so annoying in many of the older houses. The studding for a balloon frame is either 
$2 \times 4,2 \times 5$ or $2 \times 6$, and the length desired. The $2 \times 4$ studding are too light for an ample two-

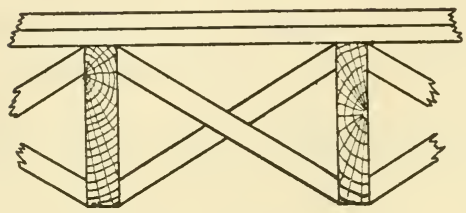

Fig. 55. Bridging the joists. story house, and they do not give enough thickness of wall for the most desirable window and doorjambs. The doors are not held firmly in place, and when they are closed quickly by the wind or by children, the plastering is injured. Studding 5 inches broad, fortified by outside diagonal boarding (Fig. 56), gives the ideal conditions unless the house is unusually large, in which case the studding should be 6 inches broad. The diagonal boarding costs a trifle more in material and labor than the horizontal, but it is so much superior that the extra expense may well be incurred. Every board forms a double brace, one where nailed to the studding and one where the siding or "clap boards" are nailed to the rough boards and the studs. Nothing has yet been discovered which is so satisfactory, and which gives such strength and protection to the frame as does this preliminary diagonal boarding, covered with paper. When completed it forms a wall open enough to prevent dry rot and tight enough to prevent the entrance of wind. 
The second-story joists rest on stringers or light girders $1 \times 5$ inches, as shown in Fig. 57. If the girder is set flush with the inside of the stud, A, the laths must lie directly upon the face of the girt. This gives no room for the mortar to form clinches behind the lath. This 5 -inch girder swells when the mortar is put on and shrinks when it dries, which may result in

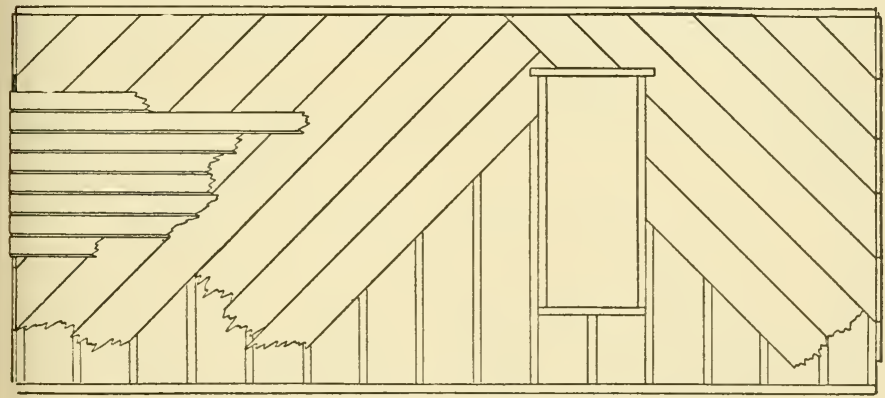

Fig. 56. A wall strengthened by diagonal sheathing.

a crack in the wall in the angle near A. Since, by reason of faulty construction, there are no clinches behind the lath, the plastering becomes loosened, and this is likely to be the beginning of serious trouble. If the girder is let in so that its face is not flush with the inside of the stud and then furrowed out with small pieces of lath, the effects of the shrinking of the girder will be obviated and room will be left for clinches behind the lath. 
In windy, cold climates, where lumber is at all abundant, a second boarding may be placed inside, covered with paper and furrowed out with a single thickness of lath to allow, as in

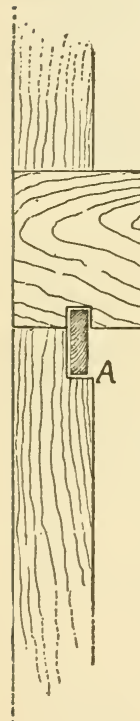

Fig. 57. Second-story joist. the former case, the formation of clinches. There is no objection to boarding horizontally on the inside, if the outside has been boarded diagonally. The term "rough boarding" has been used, but it should be said that the boarding which forms the first covering, sometimes called sheathing, should be brought to uniform thickness and matched or rabbeted.

Wherever greater strength of wall is desired than can be formed by a single $2 \times 5$ studding, as at the corners, or by a single $2 \times 10$ joist, as where partitions are to be placed, it is better to spike two or more pieces together than to have pieces sawed of the dimensions desired. These made-up pieces or timbers are stronger than solid pieces of the same character and dimensions, since the continuity of the cross-grain of the wood is broken in the made-up pieces. 
In the construction of large bridges the timbers, where exposed to the weather, are made up of smaller timbers, since they are then not only stronger but more durable and less subject to dry rot than if they are solid (Fig. 58).

Plates are made up of material 2 inches thick and as broad as the studding is wide,
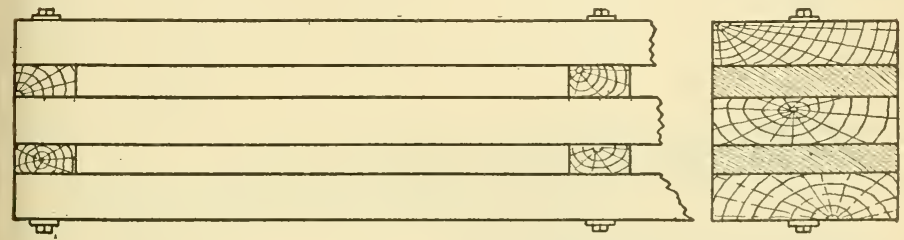

Fig. 58. Construetion of a large bridge.

doubled, with joints mismatched. This most valuable principle of building up timbers of several thin pieces is a somewhat recent practice. Where very large timbers are required, as in trussed or self-supporting roofs, the timbers of which are not exposed to view, they are frequently made up of boards 1 inch thick and as broad as the vertical dimensions desired. This method is sometimes used in constructing timbers for both houses and barns (Fig. 59).

Roofs of houses are, of necessity, extremely variable, as the house is not plamned to suit the roof, but the roof to suit the house. Flat metal roofs of all kinds should be avoided, as far as 

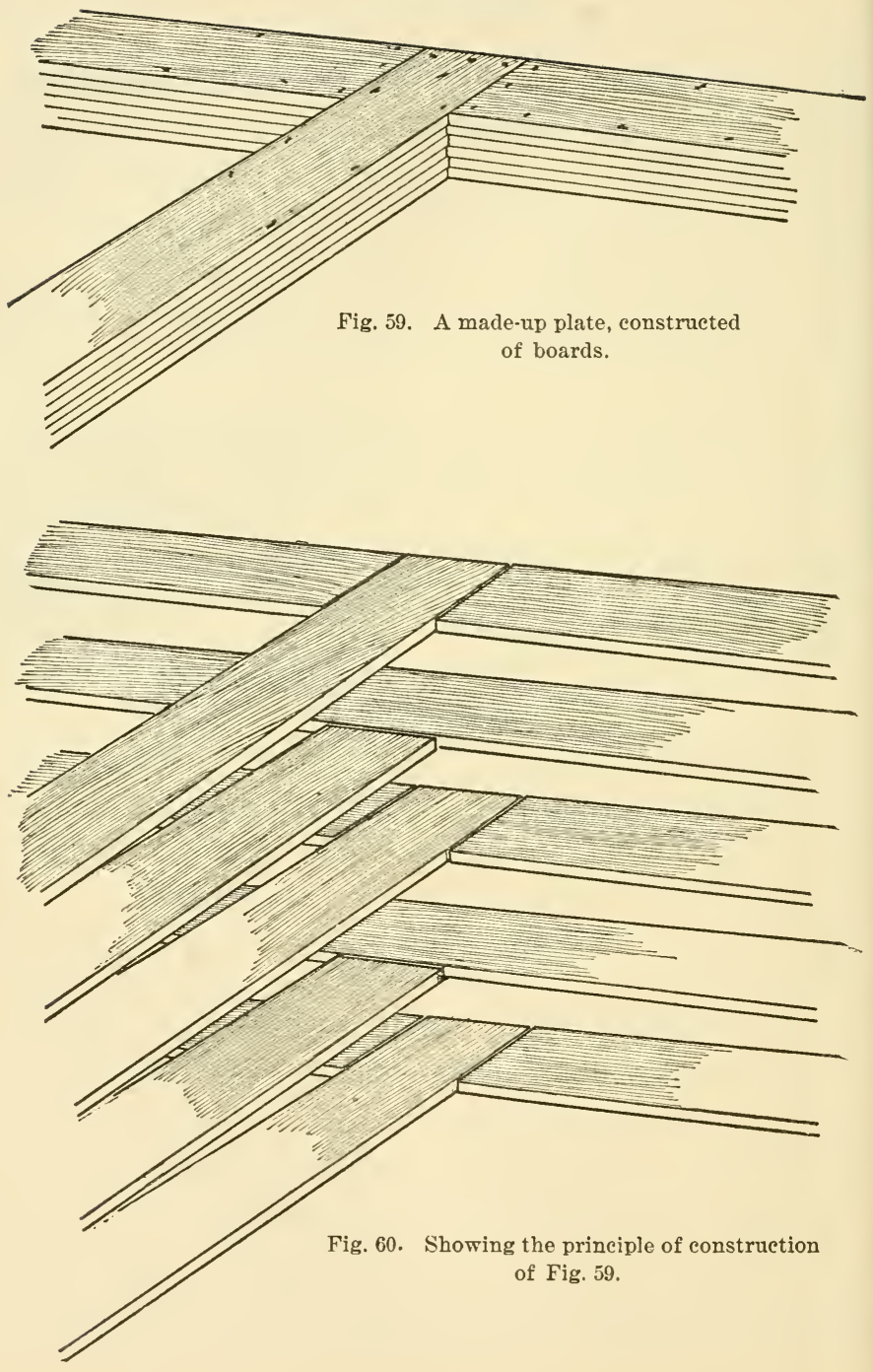
possible, on the farm house, however well they may be adapted to buildings in the city. Metal roofs are not objectionable in themselves, but only when they are laid flat on farm houses.

The pitch of roofs, like their shape, is also variable. Nothing below one-third pitch should be used except for special conditions. In Fig. 38, page 127, is an illustration of the common pitch of roofs in fashion fifty years ago. Some roofs were even flatter than the one shown. The fashion now is to construct house roofs with nearly or quite half pitch. While steep roofs are desirable if made of wood, there is some danger that the change from the nearly flat roof to the steep one will be carried too far (see Fig. 13, page $95)$. Various pitches of roofs are shown in Fig. 61. Steep roofs do not require as strong rafters, thrust less upon the plates, are more durable, and are less likely to leak than flat roofs.

Since roofs are of varions pitches,
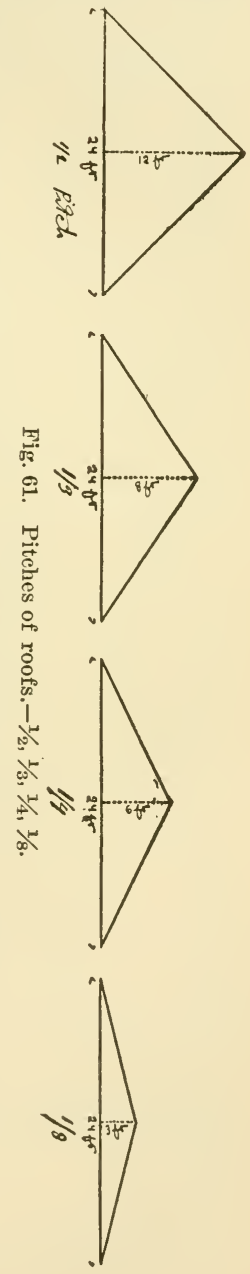
they require rafters of various lengths and bevels. Farmers and many carpenters have much difficulty in getting the length and bevels of both rafters and braces. Most carpenters' squares have socalled brace rules stamped upon their tongues.* These give the length of the brace for the shorter and more common runs, $\dagger$ but they do not give the angles of the ends of the brace. Then, too, the length is given in inches and hundredths of inches, and carpenters' squares are not divided into hundredths, so this complicated brace-rule is as useful as a steam whistle on an ox-cart.

The methods by which the length and bevels of any member of a frame which departs firom any other member at an angle are so easily understood that the wonder is that all are not familiar with them. For a simple illustration, let it be supposed that rafters for a building 18 feet broad, with one-third pitch, are to be laid out (Fig. 62). The rafter, $R$, takes the form of a brace. The run is 9 feet horizontally or half the width of the building, and 6 feet perpendicularly. If the square be laid upon the stick designed for the rafter, as 6 is to 9 , one side of the square will give the shorter and the other the longer angle or bevel (Fig. 63).

* The short end of the square.

†The perpendicular and horizontal distances covered by the brace. 


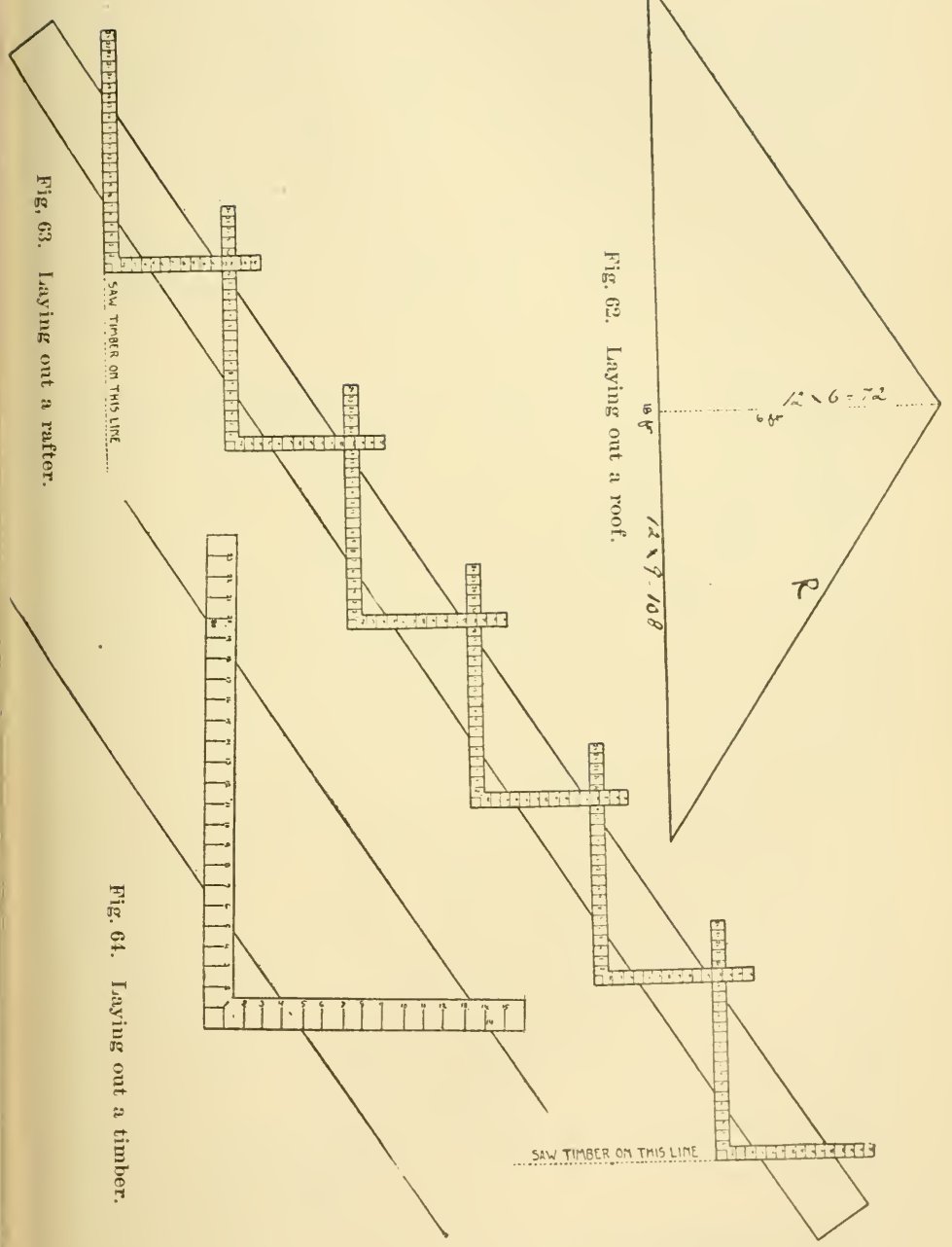


If the square is laid on 12 times at 9 and 6 inches, it will give the length of the rafter, for 12 times 9 is 108, half the width of the building, and 12 times 6 is 72 , the height of the peak above the plates. If the square is laid on $18 \times 12$ inches, the proportion is preserved, and hence the angles; the square would only hare to be laid on six times.

Consider a building 20 feet broad and 6 inches above one-third pitch. The half of 20 feet equals 10 feet, or 120 inches. Seven feet 2 inches (86 inches) is the height of the peak above the plate. It is quickly seen that this problem, like the other, can be solved in more than one way. If the long end of the square is laid on at 20 inches and the short end at $14 \frac{1}{3}$ inches, and this is repeated six times, both the bevels and the length will be secured (Fig. 64), for 6 multiplied by 20 equals 120 inches, half the width of the building, and 6 multiplied by $14 \frac{1}{3}$ equals 86 inches, the height of the peak. Or the long end of the square might be laid on at 24 and the short end at $15 \frac{1}{5}$ five times, but squares are not marked in fifths of inches, hence the previous method would be best.* The same results would be reached by laying the square on at 15 and $10 \frac{3}{4}$ inches; eight steps would

* Since the square is laid on, see Figs. 61, 62, in the same manner as for cutting a stair ; each one of these spaces is called a " step." 


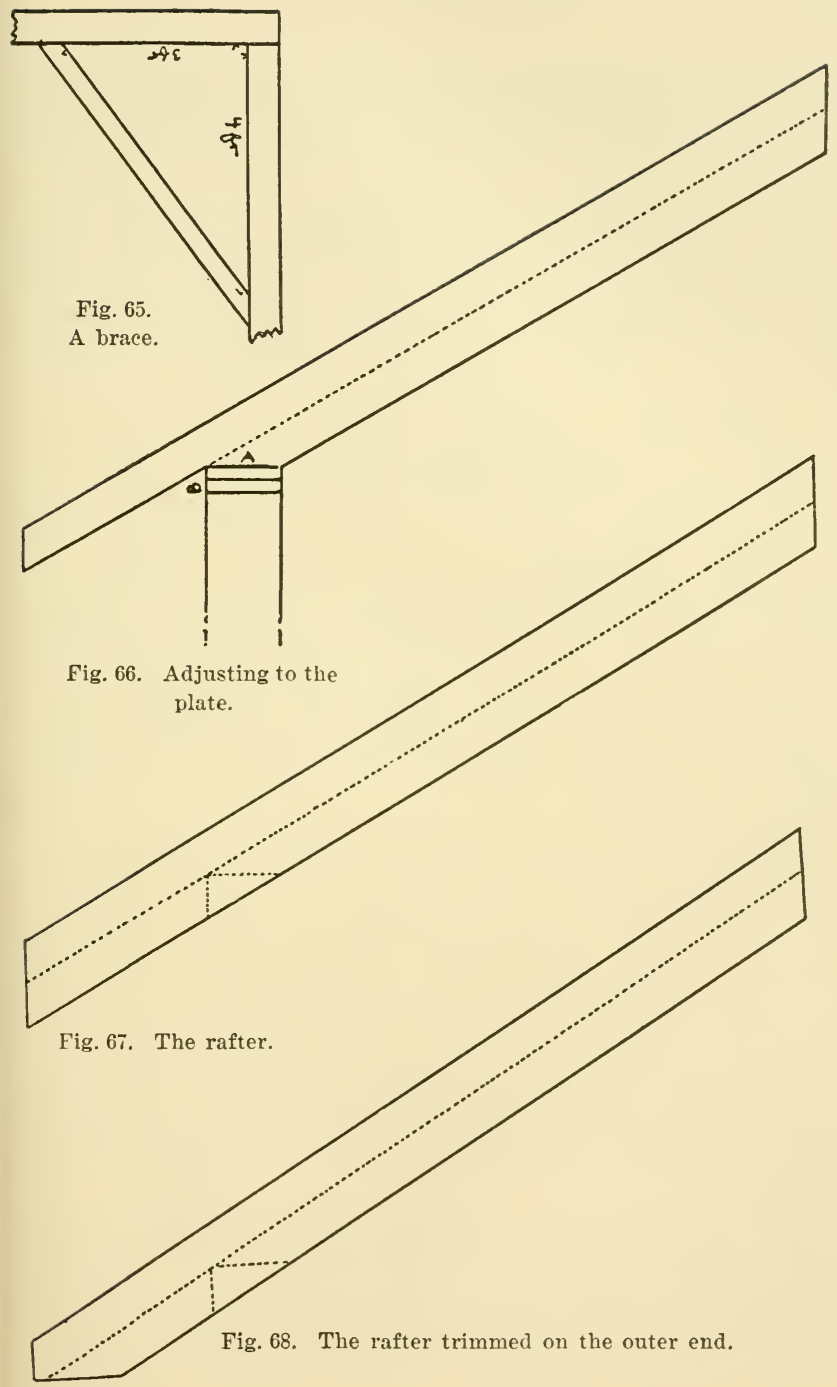


then be required instead of six. The longer and fewer the steps within the limits of the square, the bettar.

If it is desired to cut a brace $3 \times 4$ feet run, 3 steps, using the lengths 12 and 16, will give both the length of the brace and the bevels (Fig. 65). Take a rafter which has a projection requiring a notch to be cut in the lower side, and the same rule will apply. The line A, Fig. 66, is horizontal and the face of the plate is perpendicular; therefore, the line B must be at right angles to $A$. The only thing now to be determined is how deep the notch shall be, for it is evident that if the line A represents the long end of the square and $B$ the short end of the square, the notch will fit the plate.

That part of the rafter which extends orer the building may be reduced in size, but usually it is well to leare it entire (as in Fig. 67 ) if the house is large. If the lower end of the rafter should appear too heavy, it may be treated as in Fig. 68. The bevels at the ends of the rafters are the same as at $A$ and $B$ (Fig. 66).

The outlines of a story-and-a-half house, which form is most undesirable for various reasons, are shown in Fig. 69. The chambers cannot be well lighted or aired. The outlines 
of the room interfere with the placing of furniture, and such chambers are far more uncomfortable in warm weather than are those in twostory houses. It will be seen that the collarbeam, C, must be placed so far above the foot of the rafters in order to get a fair height of ceil-

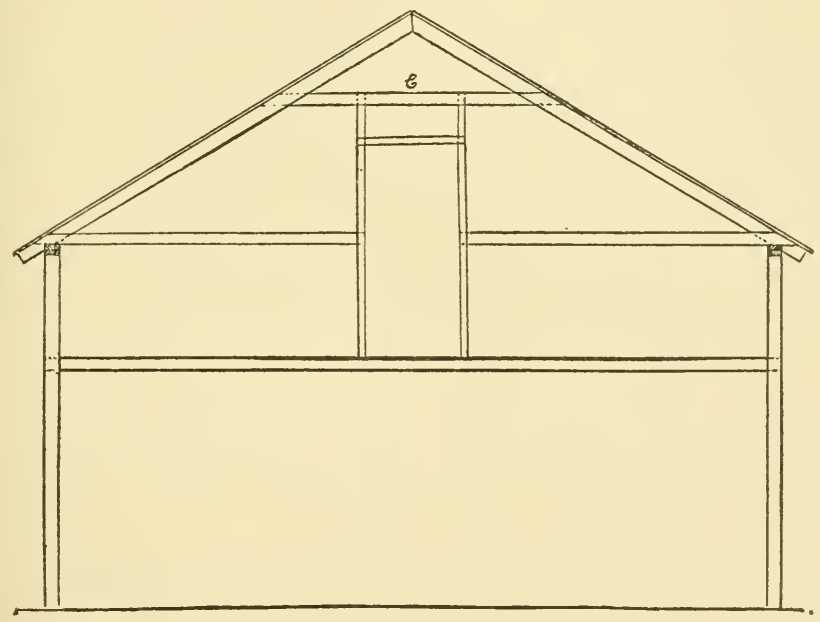

Fig. 69. Outline of a story-and-a-half house.

ing, that it has little binding power, and that the building cannot be tied together at the plates in the center, since the tie would interfere with the door in the cross wall. It will also be seen that the second-story joists are so far below the plates that their power to hold the building together is small. Many of the one-and-a-half- 
story houses have "sway-backed" peaks because of this faulty construction. (See Fig. 35, page 124, broken-back house.) If story-and-a-half houses must be built, then they should be cov-

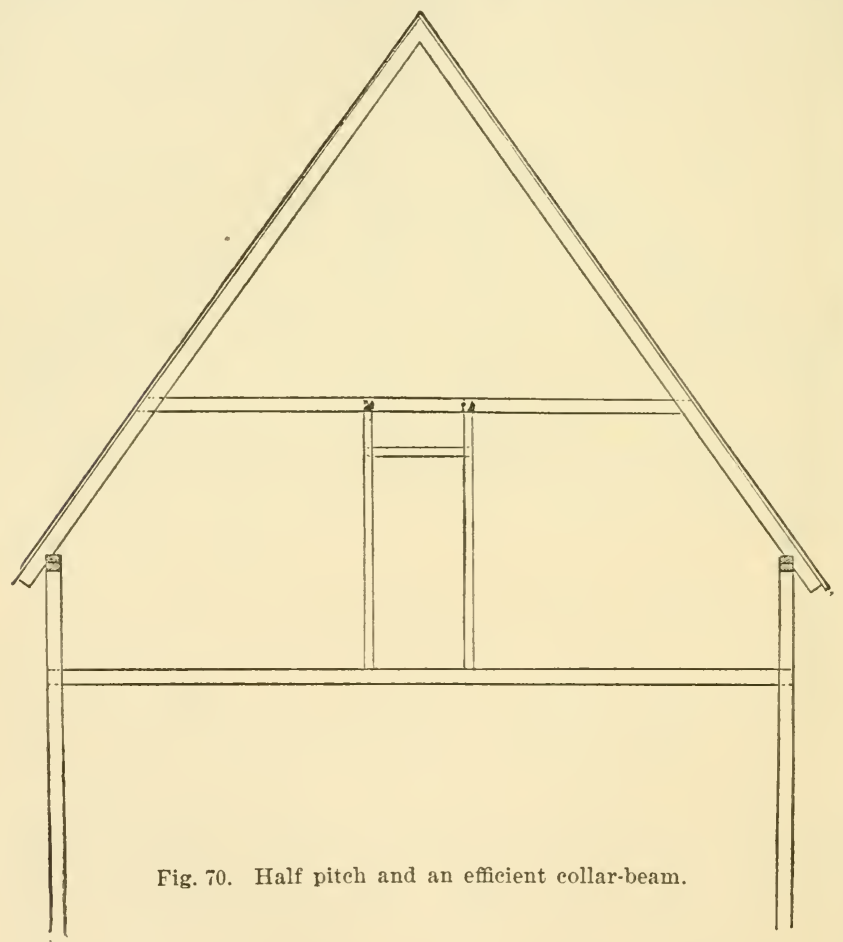

ered by roofs having at least one-half pitch, in which case the collar-beams could be placed relatively lower and the thrust on the plates would be very much diminished by the steeper 
roof (Fig. 70). One-, two-, three- or more storied houses are easily and certainly prevented from spreading since one tier of joists always coincides with the foot of the rafters, to which they can be securely fastened. Fortunately, the story-and-a-half house is less constructed than formerly. 


\section{CHAPTER IX}

\section{BUILDING THE HOUSE, CONCLUDED.-OUTSIDE COVERING, PAINTING}

THat part of the house which of necessity must be exposed to the buffetings of snow and rain, wind and sun, should be considered more carefully than any other part except the foundation. If economy demands, the doors, floors, bath rooms, and wardrobes may be of plain and inexpensive material, for later they may be replaced when means justify additional expenditure; but if the outside covering be faulty, the house is a partial failure from the beginning.

The first principle to be observed is to place all projections intended to serve as water-tables at somewhat acute angles, for if placed at nearly right angles with the sides of the house, rains accompanied by heavy winds will certainly reach the framework. The water-tables which crown the top of the base-board are more exposed than those which are higher up, and therefore should be steep and rabbeted to prevent the water from reaching the sills. The too usual method is shown in Fig. 71. An enlarged 
view of a better style of water-table is shown in Fig. 72 .

Outside window frame sills which have insufficient pitch tend to become watersoaked, and not infrequently the lower member of the window itself rots by reason of the water which drives in and remains under the sill of the window for considerable periods of time. Figs. 73 and 74 show perfect and faulty methods of construction.

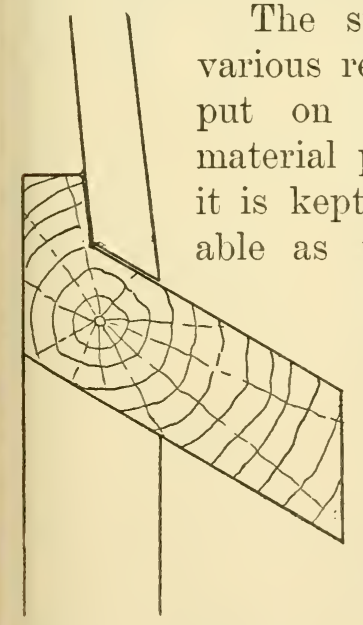

Fig. 72. A good water-table.

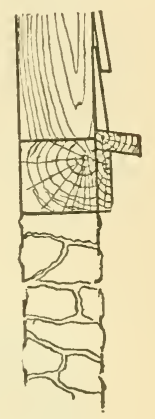

Fig. 71.

A faulty water-table. material put on this way, unless durable as when placed vertically. The horizontal covering is more beautiful, lends itself better to the numerous openings, and gives better protection from cold and wind than does the rertical covering. If the building is not to be painted, then the covering would better be placed vertically. Nearly all wooden houses are covered with either thin lapsiding or inch siding, prepared in various ways and known by various names. The inch or 
novelty siding was first introduced in the West, and costs but little more than the lap-siding, because, being thicker, it can be made of somewhat inferior lumber. The novelty or rabbeted covering gives greater strength to the building

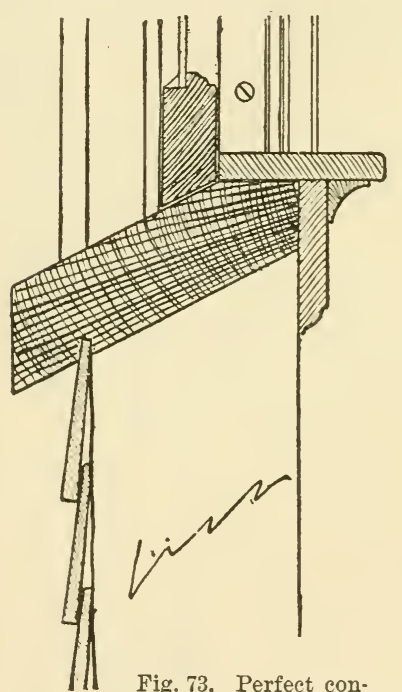

struction of window sill.

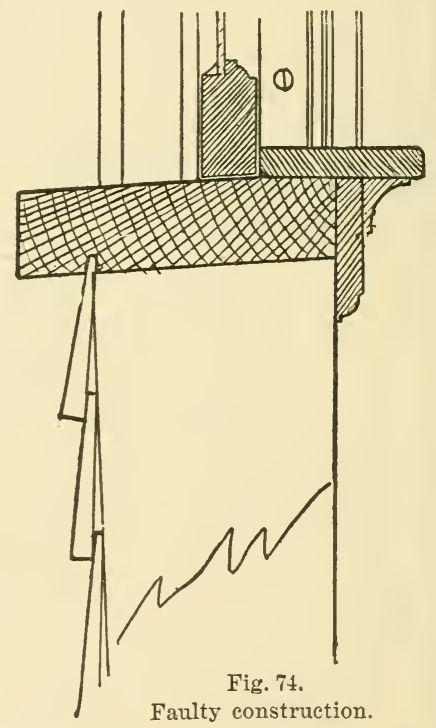

Faulty construction.

and is much more quickly and cheaply put on. It may be said that this style of covering is extremely faulty if placed on the building in the usual way, namely, before the doors and windows and corner boards are in position. If the same method of placing the. material be practiced as in placing the lap-siding, then the 
objections to this class of siding disappear to a certain extent. The diagram, Fig. 75, shows the novelty, or drop, or $\mathrm{O} G$ siding (A), the rabbeted (B) and lap-siding (C). It will readily be seen that if a drop (A) or rabbeted (B) siding be put on before the window frames are placed, as is the usual custom, an opening $(\mathrm{x})$ is left under the facing of the window frame which extends through to the studding. This permits the rain, in a driving storm, to pass horizontally along this opening to the studding and then downward along the framework of the building. Many instances could be cited in which

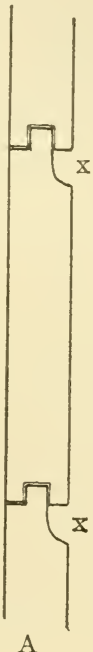

A

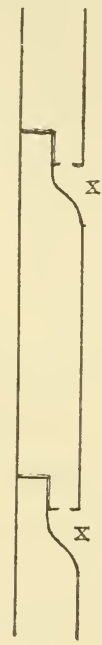

B

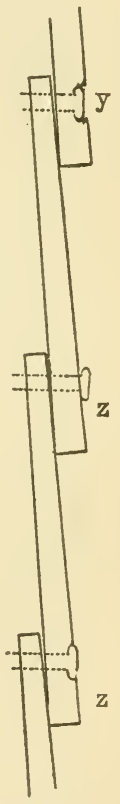

C
Fig. 75 .

Forms of siding. to be filled by triangular these openings have had blocks of wood or putty, and even then the water was not entirely excluded.

This method of covering houses or even barns with this new kind of siding is usually disappointing and wasteful of material. All that is gained is a little more facility and cheapness in 
placing the covering. If it is put on, as it should be, after the window and door frames are set, it is more difficult and more expensive to place than lap-siding.

No way of covering a wooden house has been found superior to the one-half inch lapsiding with joints tight enough at the frames and corners, in conjunction with the paint, to make water-tight joints. The lap should not be less than one inch, and the nails should be so placed that in case of considerable shrinkage in the siding the inside will give or even check, instead of the outside $(\mathrm{z})$. If made as at $\mathrm{y}$, the outside will check. This implies that the nails are to be driven rather more than onehalf inch above the edge of the siding. The nails which hold the outer covering should either be set and puttied, or the heads should be left even with or slightly above the surface of the wood, that the paint may cover all parts of the nail head. If the nails are driven too far in the heads are not fully covered and protected by the paint, in which case they will rust and present an unsightly appearance.

Some one has said that if a woman's feet, hands, and head are well and appropriately clothed, the balance of the dress may be plain and simple, and yet she will have an elegant appearance. So, if a house has a good founda- 
tion and a suitable and well-placed roof, the balance of the outside may be extremely plain and yet it will be beautiful. Some of our modern houses rest on unpointed, poorly constructed, and narrow foundations, are bedecked with peaks, pigeon lofts, and dog-eared cornices, and remind one of the suspenderless, barefooted darky crowned with a cast-off silk hat.

If the foundation is too small and shabbily built, no amount of paint and cornice can relieve the house from a look of shabby gentility. A few brown or cream-colored stones or bricks, when placed on the outside of the foundation where it shows above ground, will give dignity, beauty and a substantial look to the whole house. It may do for it what a nickel does for one's shoes.

The roof of the farm house, and for that matter of all other houses, should, in the trying climate of America, have an ample projection. An abbreviated cornice may be admissible if the building is constructed of stone which is of sufficient density to resist the American tooth of time. Fig. 76 shows a section of an abbreviated and a well extended cornice. The house which has this short-cut cornice stands within a few hundred feet of the one with the wide projecting eaves. During the past twenty years it 
has been necessary to paint the former twice as often as the latter.

The roof covering would better be of slate or tiles, for the time has passed for building temporary, make-shift houses, though

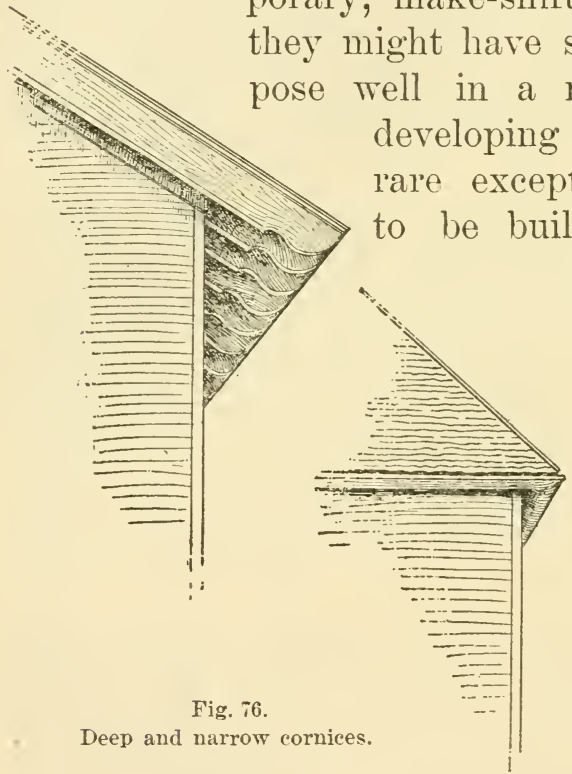
they might have served their purpose well in a new and rapidly developing country. With rare exceptions, the houses should be permanently located, well built, and of durable material. The slates which compose a roof should be not more than 8 inches wide and should not be put on roofs of less than one-third pitch, since they are only double-lapped and do not lie as closely, one upon the other, as do shingles, which are laid triple-lapped. Slate and tile roofs are comparatively heavy, and hence require stronger roof structures than shingles.

The roof boarding for slate roofs should be 
matched-tongued and grooved - and covered with paper to prevent cold and draughts of air from passing into the attic. Since slates, on account of their somewhat rough surfaces, do not lie closely together, the wind is likely to pass through the cracks in the roof, if there are any, and carry snow and rain into the upper part of the house; therefore the roof covering immediately under the slates should be virtually air-tight. The roof boards for a shingle roof should be narrow and laid with openings of from $1 \frac{1}{2}$ to 2 inches between the boards. Rain and snow seldom drive up and through the shingle roof, and since wooden roofs are more likely to rot out than to wear out, the more perfectly the shingles are dried out after a storm the better. The narrow roof boards and the spaces between them allow the shingles to dry quickly, and therefore are better than matched boards.

The short, or common, shingle of commerce is 16 inches long, $3 / 8$ - to $1 / 2$-inch thick at one end, and $1 / 8$ of an inch at the other, and is computed at 4 inches wide. A bunch of shingles contains one fourth of a thousand. It should have 25 double courses and the band should be 20 inches long. Not infrequently there is a course or two wanting, or the bands are an inch or so short. Having this data, one 
can easily determine if the bunch is of legal size. A little cheating is not uncommonly done by placing the shingles in the bunch loosely. This can be detected by examining the bunches at the thick ends of the shingles.

Theoretically, 1,000 shingles should cover 10 feet square, or 100 square feet, known in carpentry as "a square," if the shingles are laid 4 inches to the weather. Since shingles are usually laid $4 \frac{1}{2}$ to 5 inches to the weather, 1,000 shingles should cover about 120 square feet. Two-thirds of the lower part of the roof may be laid $4 \frac{1}{2}$ inches, and the upper third $4 \frac{3}{4}$ or 5 inches to the weather, if the roof is not flat.

If shingles are treated with lime water or diluted gas tar, or be painted as they are laid, the life of the roof may be prolonged. The painting of roofs with tar or common earth or mineral paints, after they are laid, does little or no good in preserving them. Sometimes painting is resorted to to make the roof harmonize with the color of the sides of the building.

Neither extremely narrow nor extremely wide shingles are desirable. Those from 3 to 6 inches wide, when carefully laid, are satisfactory. Each shingle should receive but two nails; one is usually enough, and these should be placed about $3 / 4$ of an inch from the edges, and about 1 inch above the point where the butts of the 
next course will come. When the courses above are laid upon the shingle having but one nail, two or three other nails, which are driven in the courses above, will serve to help hold it in position. The joints of shingle roofs should be double broken: that is, the joints in the shingles

Single breaks Double breaks

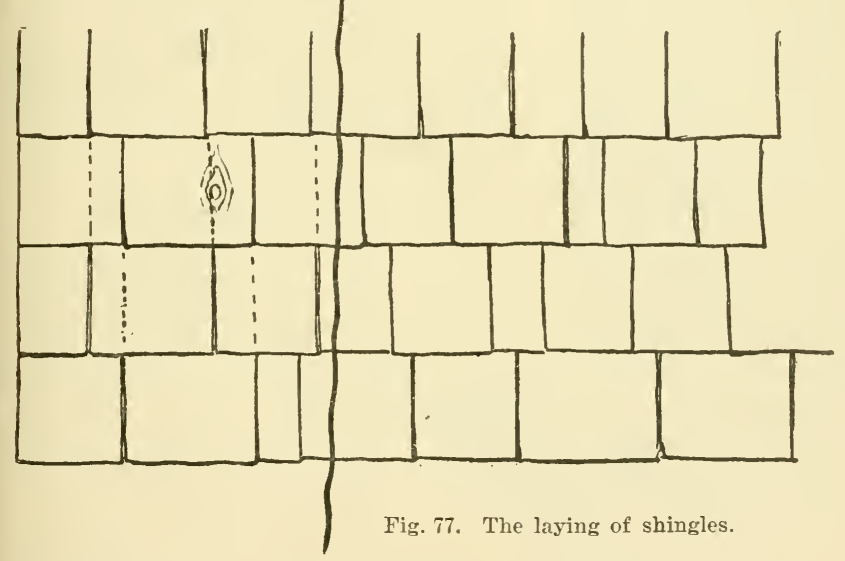

of one course should not coincide with the joints of the first or second course below. Consult Fig. 77.

If two nails be driven in the sides of an unseasoned shingle, when it shrinks it is likely to split in the middle; and in laying a roof the joint immediately abore the course under consideration is likely to come at or near the mid- 
dle of the shingle, which splits by reason of the shrinking. The case is still worse when three nails are put in a shingle, for then it is almost

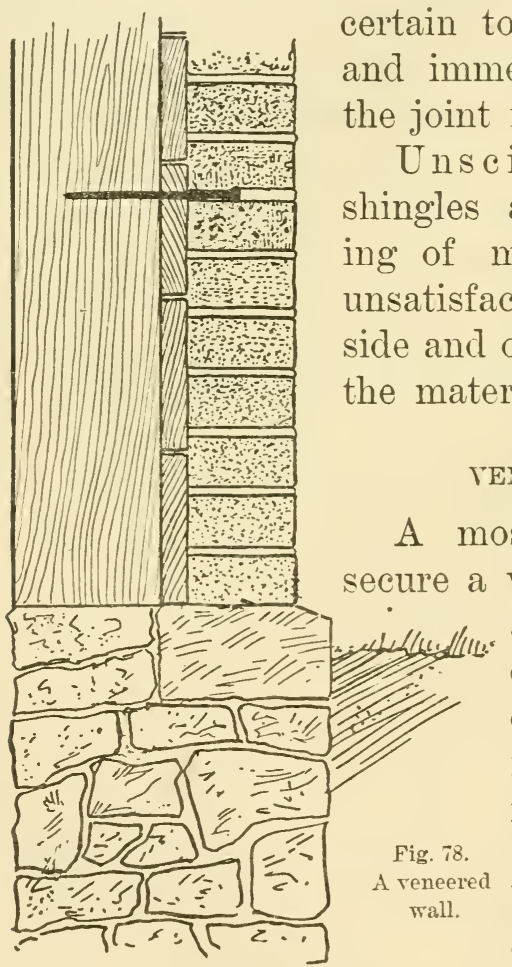
certain to split in the middle and immediately in line with Unscientific placing of shingles and insufficient mixing of mortar results in an unsatisfactory house, both inside and outside, however good the materials may be.

\section{TENEERED HOLSES}

A most excellent way to secure a warm, durable house, and one that will require the minimum of care-taking, is to first construct a 4inch wall after the frame, sheathing surfaced on one side is attached. The 4-inch brick wall is securely fastened to the wooden structure by means of 30-penny spikes, one at each studding, which are driven in at the top of every seren courses of brick. (See 
Fig. 78.) A wooden house may also be veneered with stone, the reneering, being held in place by means of metal anchors attached to the boarding.

The foundation needs to be a little stronger than for the wooden house, and must be provided with a stone water-table for receiving the veneering.

In a veneered house, all the lightness and dryness of a wooden house are secured on the inside and on the outside all the durability and solidity of a brick or stone house. When the reneering is of hard-burned, cream-colored or neutrally tinted brick or brown stone, the effect is extremely pleasing. The first cost of such a house is somewhat more than an all-wood house, but its greater durability and freedom from constant repairs makes it no more expensive in the end. When one builds such a house and covers it with a steep slate roof, he feels that he has builded for many coming generations.

It is not necessary to speak in detail of stone and brick houses, since such structures are quite expensive, and their construction should always be placed in the hands of experts. It may be well, however, to discuss them generally. The cost of building brick houses is nearly twice as great as those of wood; stone houses cost more than brick houses. The foundations of brick 
or stone structures must be broad and placed deep in the ground, to sustain the great weight placed upon them. However much pains has been taken, the walls of the superstructure often crack by reason of the unequal settling of the foundation or by unequal strain on the walls, due to the window and door openings. Once the walls are cracked they become unsightly, and cannot well be restored without being rebuilt. Unless the windows are extra large the house will not be well lighted because of the thick walls. (See Fig. 24, p. 108.)' The walls do not heat and cool as quickly as do wooden walls, hence brick and especially stone houses are likely to be damp, since the warm air of the rooms tends to part with its moisture when it comes in contact with the relatively cool walls. This tendency of the walls to condense moisture may be obviated by studding and plastering them on the inside, but all this adds to the expense. Until building material becomes much less expensive than it now is, the farmer would better build either a wooden or veneered house.

\section{OLD HOLSES}

Houses which were built some time ago and before building paper and better methods of construction were in vogue, are usually too cold 


\section{Re-siding Old Houses}

and often extremely unsatisfactory. The outside covering may be warped and cracked and too often paintless. Where these conditions prevail the house may be re-sided without removing the old covering. The window frames, corner boards, and like members which receive the siding are built out by placing bands around

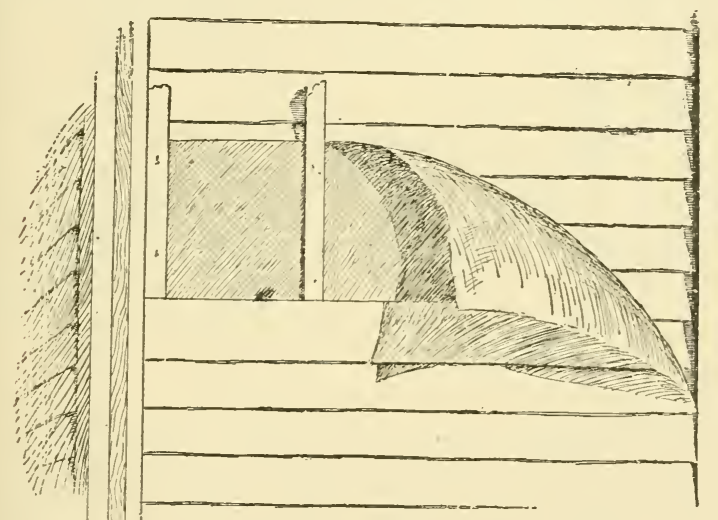

Fig. 79. Re-siding an old wall.

the frames and on the corner boards of sufficient thickness to receive the new second siding. Strong building paper is then placed over the old siding, and strips one inch thick and two inches broad are nailed immediately upon it and over the several studs of the old frame. (Fig. 79.) The house is now ready to receive new siding. If paper be laid on the floors and a well 
seasoned second floor be laid upon it, they will be greatly improved at slight cost.

Eave troughs should be placed outside the perpendicular line of the walls to prevent water from entering the house should the troughs leak or overflow from being filled with ice. Eave troughs are frequently made of tin which is too narrow, in which case, especially on flat

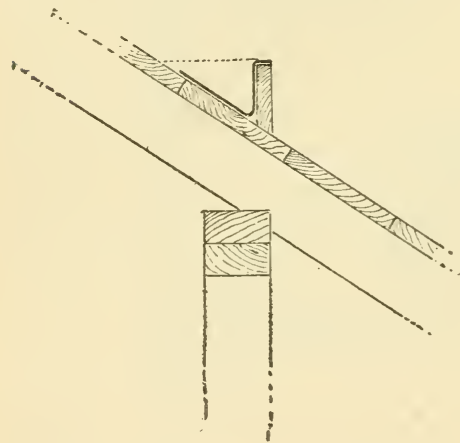

Fig. 80. Faulty gutter or eare trough.

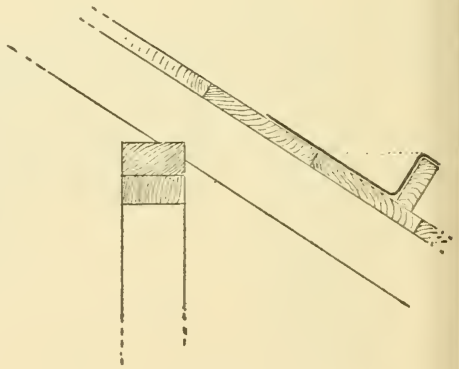

Fig. 81. Well constructed gutter.

roofs, the water will back up under the shingles and run over that part of the gutter which lies hidden in the roof. The elevation of the front edge of the gutter should be at least 2 inches below the extreme upper edge of the tin of which the gutter is made. (Compare Figs. 80 and 81.) Gutters placed at the end of the rafters are usually not as durable as those placed on the roof, but if carefully put up so that they will keep their position they serve 
their purpose well and may be made to give additional beauty to the eaves of the roof. The conductors which lead the water from the gutters to the ground should be made iarge and of corrugated material, that expansion may be provided for should they become filled with ice.

What has been said about using too narrow tin for gutters is doubly applicable to the valleys. Open valleys are better than closed. All tin used for gutters or valleys should be painted on both sides before it is placed upon the roof, and all used about the outside of the building should be kept well painted, as it is more economical to paint often than to mend leaks.

\section{PaINTING The house}

After much solicitude and money have been expended on the construction of the house, it is poor economy to let it suffer for want of paint. Not infrequently the house is planned so large, or so much is spent on its erection that means are not at hand for fully protecting the outside with suitable paints.

As to the colors of paints or their combinations, little can be said, since tastes and conditions are extremely variable. A farm house should have its own distinctive features, and its own personality, and while it may be similar to 
many other houses it should not be a duplicate of any other one.

In manufacturing towns long rows of houses are built, each one the exact duplicate of all the others in shape, dimensions, and color. The effect is abominable. This illustration of exact imitation only goes to show how necessary it is to have diversity of style in the houses themselves and variation in the colors of the paints if the maximum beauty of the home and adaptation to landscape and site are secured. In painting the farm house beauty should not be ignored, but beauty may not be compatible with durability and necessary economy. The farm home may and should be placed in such beautiful environment that the paint which covers it sinks into comparative insignificance as compared to the painting of the city house; therefore the elements of economy and durability play as important parts in the painting of farm houses as does beauty. Even a great, plain, two-story white farm house with green windowblinds can be made to look beautiful and homelike if it has a suitable setting of noble trees.

If the outside covering of the house is placed some time before it receives its first coat of paint, the wood tends to check and usually becomes too dry for applying it. If exposed for some days to the direct rays of the sun before 
painting, so much of the oil of the paint will be taken up by the wood that there will not be enough left to bind the mineral matter of the paint to the wood. This is especially the case where an attempt is made to complete the painting by the application of but two coats, in which case, the first or prime coat must contain relatively much mineral material and little oil, and must be spread thickly if the surfaces are to be well covered by the two coats. Not infrequently, the outside woodwork is swollen and somewhat displaced by rains before the roof is in place. Even after it has dried out the ideal conditions are not secured. The roof should be placed as soon as the siding is completed, or if possible before. The carpenter should put on the first, or prime, coat as fast as the house is sided; that is, the woodwork which has been placed from one scaffold or stage should be painted from the scaffold before the one above is constructed. The corner boards, window sash, and frame should receive one coat of paint before they leave the shop. The prime coat may be of yellow ochre mixed with some white lead, since the after painting with the desired color will cover the yellow if two coats be applied. Good yellow ochre is a most durable paint when properly mixed and spread, although it may be said that the more white lead used in the prime coat 
the better. Yellow ochre should contain a large per cent of iron; when ochres are composed largely of colored clay they are inferior. The paint for the first coat should, in any case, be thin, since the oil which it contains plays an important part. This first coat tends, or should tend, to fill the rood with oil so that the oil in the after coat will mostly remain with the paint, and not leave it and pass into the wood, thereby destroying its binding force. Too much stress can hardly be laid on the necessity of rubbing the first coat into the wood by vigorous use of the brush. To realize the value of this principle one has but to visit a first-class carriage manufactory and observe the methods which are in use to prepare a carriage body for its final coat of dark paint and varnish. In too many cases the first coat of paint is mixed too thickly and is not pressed into the pores of the rood as it should be, in which case the paint may either peel or rub off in a few years. The country boy dressed in his best black suit often has a reminder of this if he chances to lean against the outside of the old country church while "waiting for meeting to take up."

All outside painting, with the exception of the first coat, should be done, as far as possible, in cool weather. Early spring and late fall, when flies and dust are not present, are the 
best. If the house is built in the summer, the second coat may be put on in the fall and the third coat the following spring. The paint of the second coat may be a little thicker than that of the first, and that of the third a little thicker than the second. If the best job is desired the paint for all three coats should be mixed thinner than is customary, in which case a fourth coat will be required the following fall. The house will now have a polish similar to the well painted carriage body, and, like it, will resist moisture and remain good for a long time. If a building is to be painted at all it would better be painted at the beginning and be kept well painted, as it is the more economical in the end. Better curtail the size of the house than to build it so large that the outside covering must be neglected.

The oil used in paints is usually derived from the vegetable oil found in flax or linseed. Although many other kinds of oils have been tried, nothing has been discovered which can take the place, in paints, of linseed oil. This is most remarkable, for there are many vegetable oils which are very similar to this one. Linseed oil is expensive as compared with several other kinds, hence many attempts have been made to find an oil equally as good for painting; so far as I am able to learn, none have 
been discovered. Linseed oil in paints, when dried, forms a hard, tough, gluey coating which serves to bind firmly the particles of paint together, and to the wood, and to exclude water as no other oil does; hence if any other oil is mixed with the linseed oil, it is said to be adulterated. At the present time linseed oil is adulterated in some cases, and it is believed that this adulteration is the chief cause of the lack of durability in many of the ready-mixed paints. If linseed oil be mixed with other oils which are wanting in its valuable characteristic, it is certain that such oils will not bind the particles of paint together as they should be bound.

At present the only protection is to purchase guaranteed pure oil of dealers who are reliable beyond peradventure. Outside painting should be done with unboiled oil unless, on account of the weather, boiled oil must be used to hasten drying. In extreme cases a drier (litharge) is used. The drying process should not be rapid in outside painting, as slow drying promotes durability.

The substances mixed with the oil to form paints are extremely variable in composition and color. Some are good, and are usually relatively high priced. Others are inferior and relatively low priced. Now that so many brands of readymixed paints of many tints are in common use, 
it is impracticable to analyze all of them and determine their quality so that the inferior may be distinguished from the superior. There appears to be but two ways out of this serious dilemma: use the best brands of the ready-mixed paints and await results, or purchase pure white lead and zinc paints and pure oil, and tint to suit tastes and conditions. Heretofore, to do this successfully has required much skill and patience, especially if the house was to be painted in many colors.

Paints are now so universally adulterated that I deem it my duty to call attention to a company which virtually guarantees the material sold. The National Lead Company makes white paints of pure white lead and pure linseed oil. It also manufactures pure tinting colors, at least the company so advertise, and without doubt would be liable for damages should the paints prove to be adulterated. Sample tint cards are furnished and directions given as to the quantity and kind of tinting material to be mixed with the white paint to gire the desired colol. All this greatly simplifies painting, and if these paints are pure, as represented, the farmer will have no difficulty in securing pure paint of any tint desired.

The farmer who desires a beautifully painted house, and simplicity, may well restrict the 
colors of the paints he uses to two, being careful that they are in harmony, one with the other, and with the character of the house and its surroundings.

The following figures show the composition of some common paints (No. 1 was analyzed at the Cornell Exp. Sta., the others at the Iowa Station):

I. The paint known as white lead, when pure, is a basic carbonate of lead mixed in oil. A sample showed-

White lead . . . . . . . . 93.62\%

Oil and undetermined. . . . . . . 6.38\%

There was no evidence of adulteration.

II. White lead-

White lead .......... . 41.12\%

Barium sulfate. . . . . . . . . 30.29\%

Zine oxide . . . . . . . . . 28.59\%

Adulterated with barium sulfate and zine oxide. Barium sulfate is very heavy; in fact, in nature it is known as heavy spar.

III. Venetian red, dray-

Ferric oxide ......... 24.12\%

$\left.\begin{array}{l}\text { Calcium carbonate } \\ \text { Calcium sulfate }\end{array}\right\} \ldots . . .66 .36 \%$

Undetermined . . . . . . . . 9.52\%

Adulterated with calcium carbonate and calcium sulfate. Venetian red is ferric oxide, or a natural red oxide of iron. Calcium earbonate is chalk or limestone, and calcium sulfate is plaster.

IV. Tenetian red in oil-

Ferric oxide . . . . . . . 12.82\%

Calcium sulfate. . . . . . . $3.54 \%$

Barium sulfate... . . . . . 63.98\%

Oil and undetermined . . . . . $\frac{19.66 \%}{100.00 \%}$

Adulterated with barium sulfate and ealcium sulfate. 


\section{CHAPTER $\mathrm{X}$}

INSIDE FINISH, HEATING, AND VENTILATION

As a rule, houses are built too quickly. The frame timbers are only partly seasoned when placed; the rains which fall before the house is roofed-in and the dampness caused by plastering all conspire to swell and make damp all portions of the wooden parts of the structure. Formerly, the casings of doors and windows and the floors were placed before the rooms were plastered; the better practice of plastering on "grounds"* and placing the roodwork after the mortar is dry is now observed by the builders of all good houses. In most cases even these improved methods of construction do not result in securing what is wanted-tight floors and door's and casings which will not shrink and warp out of shape. Nearly all of this trouble may be traced to two principal causes: the lumber which constitutes the inside finish may not be thoroughly seasoned, or the house may be so damp that the

*Narrow strips of sufficient thickness to receive the lath and plaster, placed on the frame and other places where needed. 
finish swells after it is placed. In either case, when the house becomes thoroughly dried out by artificial heat or otherwise, unsightly and dirt-holding cracks will appear. When 'expensive hard wood polished floors are laid, pains is taken to provide against shrinkage by kiln-drying the floor boards and by laying them where the air and sun unite to take up extraneous moisture in the rooms and in the floor boards used.

Comparatively fer persons can afford hard wood floors, but this fact does not preclude having floors without wide cracks, which serve to retain dangerous and filthy material. There is no reason why tight floors may not be made of hard pine or other suitable material, provided a little extra pains be taken in their construction.

The laying of the floors should be the last carpenter work done in the new house. All this implies that a rough, cheap floor has been laid when the frame was constructed. The rough, diagonally laid sub-floor will cost something extra, but it results in so many benefits that it should never be dispensed with.

Windows and door frames must have inside casings, and baseboards, kitchen wainscoting and picture moldings cannot well be dispensed with. All these should be of the simplest and 
plainest construction. Fig. 82 shows a cross section of a plain baseboard, and Fig. 83 one of complex construction. Two styles of facings are shown in Fig.

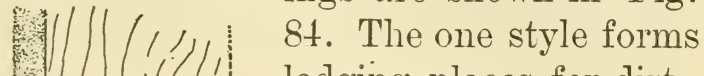
lodging places for dirt;

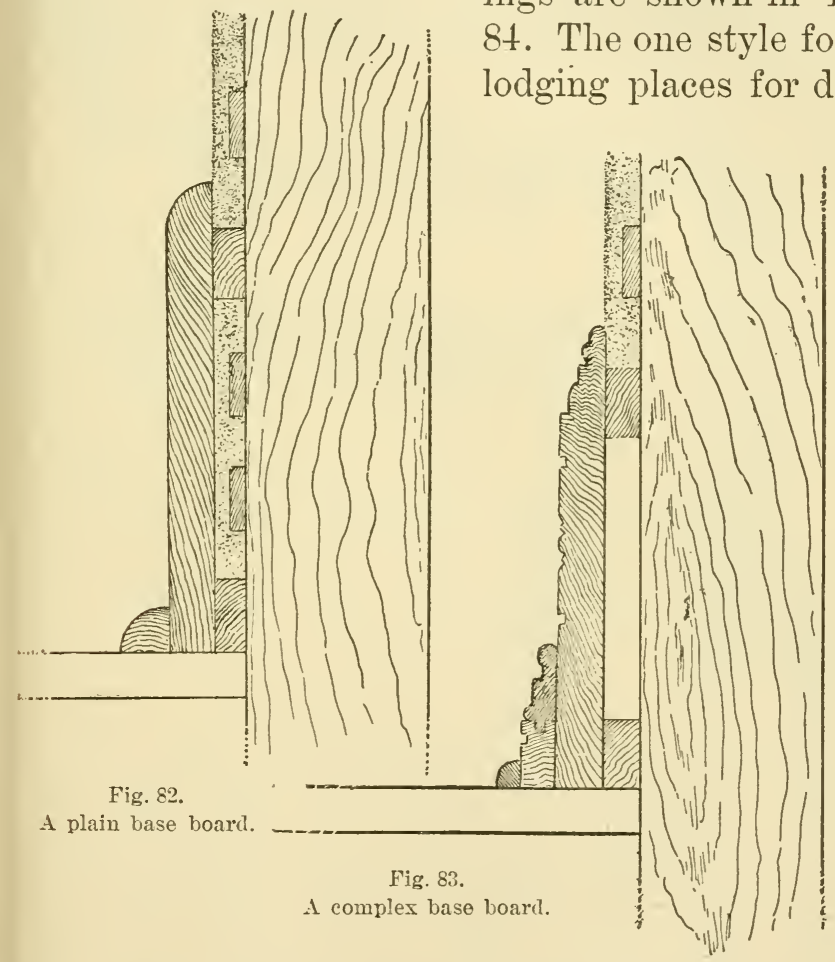

the other reduces dust catching to the minimum. I notice that some of the newrer passenger coaches, though most elegant, are built with smooth inside finish. With the excep- 
tion of the window sills there are no lodging places for dust and cinders. The oldfashioned doors with thin panels, and numerous moldings have been discarded, and those as plain and uniform in thickness as a pane

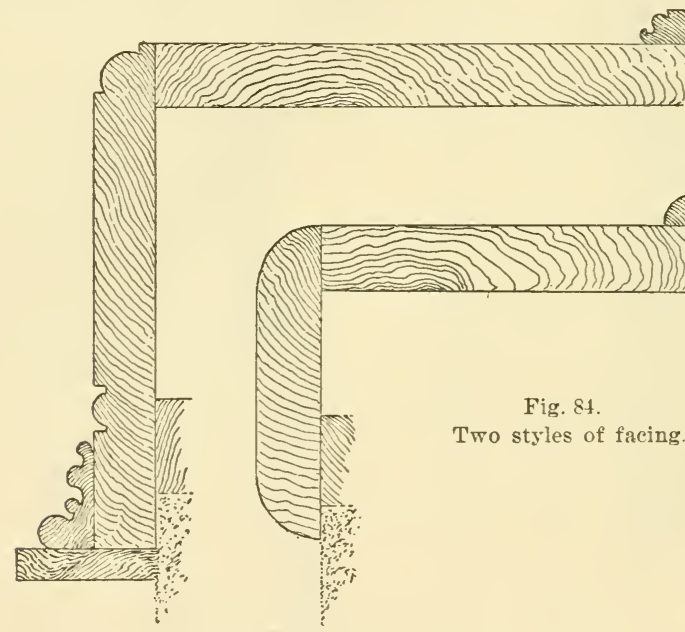

of window glass, substituted for them. The picture molding, as shown in Fig. 85, may serve to support the picture and catch dirt as well. The other illustration (Fig. S6) shows one which may serve quite as well for the purpose desired without forming a dust shelf. If the window sashes are made with plain berels and not molded, and all other window fixtures, as stops and the like, are constructed in the 
same way, the labor of keeping the house clean will be greatly reduced.

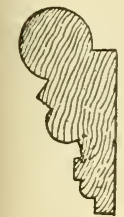

Fig. 85.

The wainscoting and the ceilings, if they are made of wood, should be constructed of wide boards, the cracks being corered with beveled battens. The old-fashioned, beaded, narrow ceiling material is not only difficult to keep The common tinted or rarnished, but almost forbut faulty pi ct u re bids cleanliness.

moulding.

Most stairs are too steep; some are little better than ladders and more dangerous. The risers in the main stairway should not exceed $6 \frac{1}{2}$ inches, nor the steps be less than 12 inches wide. The back stair may have 7 to $7 \frac{1}{2}$ inches risers, and 10 - to 11-inch steps. The best and most beautiful stair has one or more broad landings. The spiral or "corkscrew" stair is worst of all. The effort to economize space by cramping the stair is almost universal. The difference between a cramped stair and an ample one may not

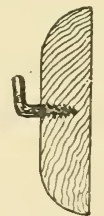

Fig. 86. A sanitary amount to more than 12 square feet of space, equivalent to the top of a small table. True, the children may go up an easy stair two steps at a time, but when their hair whitens they will bless the man who knew the difference between an easy, dignified stair and 
a step-ladder. Diminish the size of a room, add a foot to the width of the house, do anything rather than cramp the stairway.

As far as possible paint should be kept off the inside woodwork. There are but few varieties of wood which may not be made smooth; and by the use of hard oil, which is really oil and varnish mixed together, all woodwork becomes beautiful and can be easily cleaned. It appears almost sacrilegious to cover the fine grain of our native woods with cheap, adulterated paint. If some of the roods, such as ash, oak and chestnut, be sawed "on the quarter" and properly finished, they become more elegant and are in better taste than any of the imported high-priced woods. The farm house should be plain, substantial, and durable, and in many cases there is sufficient wealth to make it elegant and even refined by decorating the walls with a few fine pictures and providing useful books. Te judge people somewhat by the furnishings of the rooms in which they live, and by their appreciation of things which are really beautiful and useful.

The comfort and elegance of the rooms depend quite as much on the plastered walls as on their wooden finish. Few things are more annoying than poor walls, which may fall at any time upon the furniture and rugs, and 
may even endanger the lives of the little ones. With quick-lime and sand and an honest and efficient workman, a good, durable wall may be secured; provided, however, that the joists and studding are strong enough to prevent vibration when the floors are walked upon or the doors are closed quickly.

In plastering, the green-coat finish should not be adopted, since poorer walls will inevitably be the result than by the scratch-coat method. To the new settler on the prairies living in a covered wagon, the time consumed in building a house was important; therefore the second coat of plaster was put on a few hours after the first. The pressure required to spread, level, and smooth the second coat often disturbed the clinches formed by the first coat. The bond of these mortar clinches being broken or disturbed, the wall was made weak. It is well known that if the bond between the lath and mortar is once broken after the mortar sets, it never reunites. The only safe way to place a wall when the common mortar is used is by the scratch-coat method. This consists in allowing the first coat to become fully dry, having, however, scratched the surface of the plaster slightly soon after it is put on. When it is perfectly dry the second coat is placed, and when this is dry, a third (skim) coat may be added, which should be 
but little thicker than whitewash. This leaves the wall smooth and nearly white. Howerer, many walls are now finished on the second coat which is left level but rough, and may be tinted by mixing coloring material with the mortar. The quality of the wall depends largely upon the mixing of the mortar and the amount of firm troweling which it receives. The fewer interstices between the particles of sand the better. Firm, persistent troweling tends to reduce interstices, and hence to make the wall firm and strong. Plastered walls are much strengthened by being painted, and wherever such painting is appropriate, as in the bathroom, wardrobe, and kitchen, they should receive two coats of light cream color or other warm-colored paint.

A new mixture, cement and hair, or woodfiber, has been put on the market, and is likely to be used extensively, for when properly used a stronger, harder, and more durable wall is secured than by using the ordinary stone lime and sand mortar. This cement is sold under a variety of names, and is usually known by the builders under the generic name, adamant or adamant plaster. It is put up in barrel packages, and sells in central New York from $\$ 2$ to $\$ 2.50$ per barrel, wholesale. It is mixed in small quantities immediately before using, in the proportion of one of cement to two of sharp 
sand. One barrel suffices for thirty square yards of two-coat work, three-fourth-inch grounds being used; seven-eighth-inch grounds are required for three-coat work. As mortar made of this material sets quickly, the laths should be thoroughly wet before the mortar is applied, and the rooms should be closed while the work is progressing, or the mortar will harden too rapidly. Not only plastering mortar, but that used for other purposes which depends on cement for its binding force, should not be allowed to dry out rapidly.

One serious objection is urged against walls made of cement mortar, -it being said that they are so resonant as to be annoying. To overcome this objection the walls of one public building were covered with burlap and painted. Notwithstanding the objections raised against cement plastered walls, they are likely to come into common use, since they are so superior in hardness and durability to the old style wall.

Ordinarily, a full year should be allotted for building the house, and it should not be occupied until it has become thoroughly dried out. Perhaps this hint of the unsanitary condition of a damp house may be sufficient for the American. In Germany the law requires that a new house must have been completed a full half year before it may be occupied. 


\section{HEATING AND VENTILATION}

In the future as in the past, most farm houses, without doubt, will be heated by stoves. However, some farmers will desire either an air, water, or steam heater. Air heaters are dangerous, because if the valves are not properly managed, the pipes may become superheated and may set the building on fire. They carry fine dust into the rooms, and the heat cannot be evenly distributed when the house is exposed to the full force of the wind, as it usually is in the country. The system of heating by means of hot water has many objections when used in the farm house. The water in the pipes is likely to freeze at night in the unused rooms if it is cut off; if it is left on, all the rooms must be heated, which is frequently not desirable. Then, too, heat cannot be secured as quickly in the morning as desired, and in case of too much heat, the rooms cool slowly unless doors or windows are opened. The first cost of placing a steam heating plant is expensive, but once in place it is most satisfactory. Wherever steam power can be used to advantage in the dairy, the steam plant might well be placed in one end of the summer kitchen or in the rood house, where it may be separated from the balance of the room by a partition. There is no more danger of 
fire from a boiler than from a stove. The one plant which furnishes steam and hot water for various purposes, such as churning, sawing wood, and pumping water, need not be more expensive if it also is made to serve for heating the house.

A simple contrivance now in common use,when several buildings are heated from a central station, - serves to govern the amount and pressure of steam introduced into the building. The farm steam plant should be situated, when possible, below the level of the radiators on the first floor, that the warm water from the condensed steam may be used again in the boiler instead of cold water. In the long run, this system would heat the house more cheaply than stoves, require less care-taking, and be cleaner and more satisfactory in every way.

Much has been written about ventilation; and too often the systems applicable to ventilating large, overcrowded rooms and public halls have been applied to dwellings. However complex and difficult the ventilation of large buildings may be, the ventilation of a room in a dwelling is simple. If there are two or more windows in a room, ideal ventilation can be secured by raising the lower and lowering the upper sash as much as desired. By this method three streams of air are allowed to enter or leave the room, as 
there will be openings at the top, bottom and middle of the windows. The impure air is largely found at the top of the room and at the bottom. If, then, the warmer and lighter air is allowed to escape at the top, the colder air will rush in at the bottom, which will result in keeping it moving as water moves when the inflow is at or near the bottom of a ressel and the outflow near the top. Whenerer only one window can be secured in the sleeping room, large transoms should be placed over the doors into the hall. While this method does not ventilate as well as the other, it serves to keep the air pure in the chamber. When there are many rooms situated on one hall, the hall should be ventilated by means of windows at its end, or at the top of the house. Many farm houses are over-ventilated in winter, the cold air entering the loose casements until the wash water expands and breaks the pitcher. In such cases storm sashes are a necessity, and are more economical than feather beds or coal in preserving a living temperature. 


\section{CHAPTER XI}

HOCSE FURNISHING ANE DECORATION

House furnishings do not exist for themselves, but as a background for the people who live among them. Just as the trees, rocks, fields and animals have for their setting the green earth and the blue sky, and as pictures have a background, a middle distance and a foreground, so human beings have their setting. If the setting be more striking or more elegant than the people for whom it exists, they are made uncomfortable and overshadowed by it; if meaner and uglier than they, the people are belittled by it. How many houses there are whose furnishings are much more attractive than their inhabitants! A woman of superficial education and trivial character has the distinction of having the most beautiful library in her state; rows on lows of the best books, in beautiful bindings, in a room of the most artistic design, and nobody to read them. The contrast between the woman and her environment is pitiful.

The house and its contents should be an out- 
growth of the tastes, habits and occupation of its owners. Farm life in its best aspect is a synonym for breadth, generosity, simplicity, cleanliness, abundance of sunlight, fresh air and good food, the beauty of nature, freedom from stiff formality - these are the things which the city dweller envies the farmer. The equipment of the house should express this breadth, beauty, and freedom of life. It follows from this that many pieces of furniture and some kinds of decoration which are offered in the shops are quite out of place in a country house. Imitation is, therefore, a dangerous principle, for it is likely to lead to the choice and purchase of articles which, however suitable for some other family and pretty in themselves, are wholly inappropriate in the case of the purchaser.

There are three main considerations which should always be taken into account in housefurnishing: health, suitability, and beauty. The order of these is often reversed to the permanent injury of the housewife. The first law of hygiene is that nothing can be suitable which is not wholesome for those who are to use it; the first law of decorative art is that nothing is beautiful which is not wholly suitable. If these principles should be applied to the furnishing of country houses, they would taboo dark, thick window draperies, nearly all bric-a-brac, heary 
upholstered furniture, parlor tea-tables filled with delicate (and generally dusty) china, and many other things which have been copied from the unwholesome and perhaps necessary customs of city life.

Taste is a matter of cultivation, as much as efficiency or honesty; the habitual application of its fundamental principles in one's own household, and the seeing of beautiful things elsewhere, are the chief means of its development. Man obtained his first conception of beauty from the form and color which he saw in the world about him, and we have only to apply the principles which are there apparent, in order to develop good taste. Nature provides an immense and comparatively neutral background; Nature always makes curves, never angles; Nature blends the most sharply contrasting colors together in the butterfly's wing, in the poppies in a meadow, and in the feathers of the robin's breast. The greater part of the world is in soft colors, browns and grays, dull greens and dull blues; the brilliant yellows, reds, pinks, purples and blues are always in very small quantities against this rery large, neutral background. Since the furnishings of a house are the setting of the people, none of them should be more conspicuous than the people. Whaterer brilliant color there is must be in relatively small quan- 
tities against a soft background. Nothing either in form or color should "stick out."

If the general principles just laid down be applied to the details of house furnishing, we shall find that many matters must be changed. Since the housewife must usually do her own work with very little or, at most, inadequate help, everything should be planned to save her strength. If we remember, also, that the first effort of good housekeeping is to keep dirt out of the house, and the second to get it ont at once, it will appear that carpets are unsanitary. It has already been shown that good foors are now to be had easily and cheaply. If properly painted or finished with oil and wax, they form the best foundation for tasteful and cleanly housekeeping. Carpets not only keep the dirt in the house, but they involve that annual bugbear, house-cleaning. Even when the floors are old and poor, the space around the edge of a rug may be puttied and painted so as to look rery well when the rug is put down. By rugs, I do not mean sereral little rugs, like oases in the slippery surface, or at the doorways to trip the unwary, but a good, generous-sized rug. which just escapes the edges of the heavier furniture around the sides of the room; which is substantial enough not to roll up, and which is yet small enough to be carried in and out by one 
person. If the woodwork and pictures be wiped with a damp cloth, the windows washed, the floor dusted, and the rug beaten out of doors, now and then, no such terrible upheaval as house-cleaning usually implies, is necessary. Rugs may be had ready-made of ingrain, Japanese cotton, and jute, Brussels, and more expensive materials, but should always be heavy enough to lie flat without fastening and large enough to cover the entire portion of the floor which is to be walked upon. The uncovered space should usually not be wider than one and one-half feet.

All furniture that is not actually built into or fastened to the wall and floors should be easily movable and easily cleaned. This at once precludes the purchase of heary, upholstered chairs and large sofas. Wicker and rattan furniture, though not so artistic and costly as antique wood, is very light, and with good removable hair cushions, may be made quite as comfortable and far more cleanly than upholstered plush and damask. The cushions may be beaten at the same time as the rugs, and the dust thus taken out of the house. White enameled bedsteads and washstands are rapidly superseding the heavy wooden ones. It is a curious fact that although the persons of a family are of various sizes and ages, chairs are 
still bought by the half dozen, without reference to the people who are to sit upon them. Even in such minor matters as chairs and tea-cups, some account should be taken of indiriduality.

If all furniture be selected with these simple principles in mind, i. e., hygienic cleanliness, the minimum of labor for the housewife, and the comfort of those who are to use it, there remains only one other way in which to go astray: it may still be superlatively and positively ugly; or it may be comfortable, sanitary, easily mored, and yet be merely negatively ugly; or it may be made decorative by its graceful form, the color of its covering, or the carving upon it. The first principle of artistic decoration is that it must be wholly subordinated to the use of the object which it adorns. For instance, windows are for two purposes: to light the house and for seeing out. If a window opens on a barnyard or some umpleasant prospect, you may put up a sash curtain of light silk or muslin. Thus you obtain light but no view. But if you wish to see out of the window, sash curtains are absurd. In the ordinary private house, elaborate and heavy window curtains are out of place, both for sanitary and artistic reasons. Whenever cleanliness is a prime object, drapery should be movable and washable. Silk and relvet dra- 
peries are only to be tolerated where there is a retinue of maids to keep them clean.

The facility and cheapness of mill-work and lathe-work in wood has vitiated the taste of Americans to a terrible degree. Nearly all readymade furniture is grooved, machine-carved, and ornamented in a way to violate not only the principles of beauty, but of strength and cleanliness as well. Ornament that does not mean anything is not merely commonplace but ugly. There are four chairs of different patterns, and costing from $\$ 1.50$ to $\$ 15$, in the room where I sit; all of them have legs. Now, legs are intended as a support, yet all these are grooved and beaded and hollowed out in spots, so that twice as much material as is necessary has been used to insure support. The ornamentation is not pretty, the hollows are inevitably full of dust, and they mean absolutely nothing to anybody who sees them. On the front crosspiece of one large chair is glued a design of leaves in oak, by way of ormament. If these had been carved out upon a beautiful strip of wood by the hand of a cunning workman, they would at least have meant a man's thought and skill. As they are, they suggest merely a machine and a glue pot, and thousands of others as hideous as they. Contrast with this gingerbread furniture the plain, substantial colonial chairs and tables and 
sideboards, made of beautiful wood, almost without ornamentation, with shapely, slender, and strong legs and softly polished by hand. Cheapness and quantity have been secured by machinery at the expense of beauty and strength.

If the principle thus illustrated be true, then it follows that patterns of any sort, whether in carpets, wall paper, china, or drapery, must be very carefully used that they may not be more conspicuous than that which they decorate. The floor and the wall are the basis both of colorscheme and decoration. They are the background of the people who are to live there; they should, therefore, be rather inconspicuous, soft and indefinite in effect, and as becoming as possible to the human figures. If the climate be sunny and the room well lighted, the walls and floor may be dark and rich in effect; if the climate be uncertain and often cloudy, or the room badly lighted, the effect should be light and gay. Color is the chief means of producing this result: the walls and floors of living rooms should be of soft, neutral brown, yellow, red, green, or warm gray tints. Blue, though very lovely when carefully used, is cold in effect, and seldom satisfactory for living rooms, while the blue grays are positively chilling. Yellow in paler or richer shades, depending on the light- 
ing of the room, is uniformly cheerful and satisfying; next to it rank the various terra cotta shades. Neither rug nor wall-covering should have large, striking designs; if having pattern at all, it should rather be of an indefinite, wandering design like the Japanese jute rugs, or of small inconspicuous conventional design, such as may be found in the best Brussels carpet.

If the floors, however, be poor and old they may be covered rery inexpensively with thick, strong building paper which comes in beautiful tints and the rug may be laid on top of this; or with denim on top of newspapers, which is only a little more expensive, and which may be had in a variety of beautiful shades; or, best of all, with matting on top of paper. Matting is especially desirable because the dust sifts through below, and does not rise easily when swept. But the money spent to cover up a poor floor would often serve to lay a good new one, and this should be done whenever possible. For kitchen and, in some cases, for a dining room floor as well, nothing is so satisfactory as linoleum. It is impervious, warm, soft to the foot, easily kept in order by an occasional coat of oil, and to be had in agreeable patterns. It may also be used like denim, building paper, and matting, to cover up bad floors, and as a 
basis for the rug; while more expensive, it is also much more satisfactory than anything except a good hardwood floor. There is often far too great contrast between the furnishings of the living room and the parlor; between the "spare room" and the family bedrooms. The money spent in elegance which is shut up in a room rarely used would serve to add much to the comfort of the whole family. The guest will enjoy the hospitality offered all the more if not treated too ceremoniously.

The furnishing of the living room should always include sereral easy chairs, a good lounge, a place for books and magazines, and a thoroughly good reading lamp. If it can be afforded, a small room off the sitting room for writing and study is very desirable. It should contain book shelves, a large writing table or desk, and a good lamp. But if the extra room cannot be had, the desk and book shelves may be placed in the parlor. There should certainly be some place where the children may study or any member of the family may read and write minterrupted. It is as irksome to write without proper appliances as to bathe without proper facilities.

The furniture and decorations of bedrooms can scarcely be too simple; the walls may be lighter and gayer than those of living rooms. 
Blue and white or pale green and white may be used as color-schemes for very sunny bedrooms, yellow or pink and white for less sumny ones. One or two single, white, enamelled iron bedsteads, a washstand, a bureau or a chest of drawers with glass above, two or three low, light chairs, and a table or desk at which one may write, is an ample furnishing, if there be a good closet or wardrobe. The rug need be only large enough to cover the space in front of the bed, bureau, and stand, if the floor be well matched and painted or oiled. A bedroom should give the impression of spotlessness and comfort; everything should be washable or cleanable; unless used also as a sitting room, it should not have a superfluous article in it. Mats, brica-brac, even many pictures, are quite out of place.

Since cost, styles and tastes differ so widely in different localities, no detailed directions can or should be given that will be generally applicable. If the principles illustrated in this chapter be correct, they will serve to guide and to develop the taste of many different kinds of persons. 


\section{CHAPTER XII}

CLEANLINESS AND SANITATION-WATER SUPPLY AND SETAGE

Filth and disease have gone hand in hand from the beginning of the world; but only during the last quarter-century have we known the true cause of infection, and why it is so closely associated with dirt. The danger of uncleanliness lies in the existence of certain microscopic organisms belonging to the regetable kingdom, known popularly as microbes or germs, but more properly as bacteria. Bacteria, like the plants with which we are more familiar, thrive in moisture and moderate heat, but differ from them in many respects. Some of the more striking differences are structure and method of reproduction, many of them possessing the faculty of growing without sunlight. Bacteria are composed of minute masses of regetable matter which vary from one ten-thousandth to onethirty thousandth of an inch in length, and they reproduce by simple division. This process of multiplication may occur as often as once in half an hour; thus immense numbers may de- 
velop in a very short time. Under conditions unfarorable for growth, some species may form within their interior dense masses which are called spores. These resemble the seeds of higher plants in their function of distributing the species and in preserving life through intervals of time unfavorable for continuous multiplication.

Bacteria may be classified in several ways, but for the discussion of cleanliness and sanitation, the simplest division is into the harmless and the injurious. The harmless forms live mostly on dead organic matter, causing nitrification, fermentation, and putrefaction; they break down the more complex organic compounds into simpler ones, so that they can be used again as food for plants. Familiar examples of this are seen in the decay of meat and vegetables. This class is more numerous, much hardier than the other, and comprises an overwhelmingly large proportion of the bacteria in nature.

Bacteria are found almost constantly in water, in soil, and in air. Consequently they are present in all our food, except that which has been heated to kill them. Certain bacteria are normal inhabitants of the mouth, throat and intestines, while others find suitable conditions for growth on the skin and in the accumulation of substances excreted in the perspiration. 
Owing to the short time which has been devoted to the study of bacteria and their functions, closer attention has been paid to the harmful or pathogenic bacteria because of their relation to human health. This one-sided study of bacteriology has blinded us to the beneficent action of many bacteria, and has caused us much unnecessary fear of their presence in food.

The harmful bacteria cause disease either indirectly through poisons which they excrete in food products, or directly by poisons or toxins which they form when living within the body. Although harmless bacteria are everywhere present, the pathogenic or harmful varieties are ordinarily much less numerous. It should be understood, however, that many of the so-called harmless bacteria are the cause of certain decompositions of regetable and animal matter with the formation of substances which are detrimental to health. This is illustrated by the occasional cases of meat, fish, and oyster poisoning. The pathogenic bacteria, such as those of tuberculosis, typhoid fever, diphtheria, and the like, constitute, as has been already stated, a small number of species. These are disseminated through rarious chamnels, such as the milk and the water supply, and by persons directly. When they are introduced into dirty and unwholesome homes, they find in the filth suitable 
conditions for their multiplication, with the usual consequence of causing more or less disease in the family. The human body possesses more or less power of resistance to bacteria, but if these natural forces cannot overcome their invasion, they in turn will be successful and produce disease.

Once infected with disease-producing bacteria, a house should be renovated from attic to cellar, and subjected to the action of agents possessing the power of destroying the pathogenic organisms. Numerous means are employed to kill bacteria, among them being the use of disinfectants in the form of liquids or gases, and the application of heat. The list of chemical disinfectants is long, but owing to their cost, a relatively small number are available for the disinfection of houses. The use of carbolic acid, copperas, whitewash, and the fumes of burning sulfur are familiar disinfectants used for this purpose. Among the disinfectants which can be applied directly to wounds, to prerent suppuration, are weak solutions of corrosive sublimate and of carbolic acid.

The greater number of bacteria, pathogenic or harmless, which do not form spores, are destroyed by a temperature of 155 degrees Fahrenheit for twenty minutes. Tery few resist the boiling point; thus water may be made safe by 
hoiling, and milk by Pasteurizing at 155 degrees for twenty minutes. Cold merely checks the growth of bacteria, but, ordinarily, does not destroy them. Sunlight and fresh air are especially unfarorable to them; therefore the house should be sumny, and beds; bedrooms and living rooms thoroughly aired. If there be no organic mattel to serve as nutriment for them, they cannot multiply; therefore the body, the clothing, and the dwelling should be kept as clean as possible. For this reason the first test of good sanitation is the immediate removal of all waste matter from the house, and the first preventive of disease is personal cleanliness.

In Chapter VI suggestions have been made concerning the site, location, and drainage of the farm house. The kind, number, and convenience of the sanitary appliances, such as hot water boilers, closets, lavatories, and baths, are chiefly dependent upon the water-supply. If there be an abundance from a town water-main, or from a windmill or house-tank which will give some pressure, the problem of plumbing is comparatively easy; but if there be no such supply, it becomes far more difficult. A good water supply in the house is of the first importance; therefore, for several reasons, plumbing conveniences lessen the work of the housewife by half, they encourage the practice of that 
virtue which is "next to godliness," and if properly arranged they do away with many sanitary dangers. Personal cleanliness is irksome enough with every convenience for washing and bathing. When there is no convenience except a wash basin and a quart or two of hot water, habitual cleanliness is practically impossible. In this respect town and city life have an immense advantage over rural life. A woman who had moved from town to country for the sake of her husband's health, was asked how she liked it: she said, "It is delightful, but I sometimes think I cannot endure it on account of this nasty privy and no bath-room." Cleanliness of the skin is hygienically far more important than cleanliness of clothing. In athletics and gymnastics, the bath following the exercise is considered an essential part of their hygienic value; how much more necessary, then, is opportunity for frequent bathing, where the family, both in and out of doors, do daily manual labor which causes much perspiration, and which is often very dirty! The recent movement in cities to provide public bath-houses for the poor in tenements should not outstrip the farmer's effort to obtain equally good facilities.

If there be a sufficient water supply available, there should be in every house a hot water 
boiler of at least twenty gallons capacity, attached to the kitchen range, to supply hot water for laundry work and bathing; a kitchen sink and a bath-tub, each with hot and cold water faucets and waste pipe to sewer or cesspool; and a water-closet. These are the essentials; but, if possible, a stationary wash stand and two laundry tubs, with hot and cold water pipes, should also be provided. In the farm house it will save expense and many steps for the housewife, and will encourage frequent use, if all these be located on the first floor ; the boiler in a cupboard in the wall of the kitchen, which may be shut in summer and opened in winter; the sink in the kitchen, or if preferred, in a pantry between the dining room and kitchen; the bath-room and stationary washstand in a room either opening out of the kitchen or out of the family bedroom, or out of a rear passage; the water-closet should be in some well ventilated space, on an outside wall, where the noise of the fixture will be as little heard as possible. It should have an outside as well as an inside entrance. It is customary to place the closet in the bath-room, but this often interferes with the general use of the washstand and bath-tub by the family, and should be avoided. The nearer all plumbing fixtures are to each other, the less expensive they are to 
put in ; therefore in planning the first floor, this point should receive special consideration.

Certain general principles apply to all plumbing, and may serve to test the various kinds of fixtures offered for sale. All foul and effete matter should be immediately and completely removed from the house; any back current of foul air into the house should be prevented, and any communication between the sewer or the cesspool and the water supply should be made impossible. Fixtures should be as simple in construction as possible and easily accessible. Pipes were formerly enclosed in the walls, but in the finest new buildings in cities, are now placed altogether in sight, and painted the color of the walls, or of the woodwork. The sewer pipe, on reaching the level of the ground, should pass directly out of the house, and should never be carried along under the first floor of the house. In the southern states and on the Pacific coast, pipes may run on the outside of the house, thus fulfilling ideally the principle that waste matter should be removed from the house as soon as possible. A few years ago there was much controversy over the placing of vent pipes in traps and in branches. Gerhard and the older sanitarians advise a complicated and elaborate use of them, but Putnam and the more recent authorities consider thor- 
ough ventilation of the soil pipe at top and bottom quite sufficient. The material of fixtures should be good (not extraragant), and the workmanship should be of the rery best. The efficiency of any sanitary convenience depends almost as much upon the care with which it is put in as upon its material and style. But of all the principles of sanitary plumbing, probably the most important is frequent and thorough flushing, if possible with hot water. Any fixture will become foul and dangerous if there is not water enough and under sufficient force to scour it out thoroughly.

Having laid down certain principles which apply to plumbing fixtures generally, we may now consider these fixtures more in detail. Pipes should be rather heary. Waste pipes are generally too large, and therefore do not scour well; they need be only three to four inches in diameter for one or more closets in an ordinary house, and from-one to one and a-half inches for washbowls, sinks, and tubs; they should always be of uniform size, i. e., "full-bore" throughout. Soil pipes should never run level, but as nearly as possible at a uniform slope of not less than one foot in fifty.

The kitchen sink may be of white porcelain, enameled iron, painted iron, or granite ware, any of which materials are serviceable and desir- 
able; or of wood, lined with lead, zinc, copper or slate, all of which are more or less undesirable, because after some use, the water and filth is apt to get in between the wood and its corering, or because they are not durable. The sink should have as little woodwork about it as possible, since wood is porous and, therefore, collects filth. It should be set open on brackets, and not over a dark, moist, dirt-collecting, back-breaking closet. Flushing is especially important in the case of the kitchen sink because of the grease. The best plumbing provides a grease-trap outside the house, which may be easily cleaned; but whether outside or imnediately beneath the sink, the trap should have a screw-plug, so that it may be frequently cleaned. It follows that the kitchen waste pipe should not be too large, should have a good incline, and if possible no abrupt curves, so that cooling grease in the water may not harden on the sides of the pipe and finally fill it up. The use of a cheap wire screen garbage basket in the sink will prevent the small particles of waste from passing down the pipe.

Bath-tubs of white earthenware or "porcelain" are the most expensive, the most durable and very heary; of white enameled iron, are less expensive and heavy, durable if carefully used, impervious and cleanly; those of 
copper, tinned and planished, dent easily and the tinning wears off, but are fairly durable and still less expensive; those of wood-fiber are not very common, but are impervious, light and cleanly.

The stationary washstand bowl and top are usually of marble; the outlet of the bowl should not be smaller than the wastepipe; the trap should be near the bowl, and have a screw plug, so that obstructions may be easily removed.

There is an immense variety of water-closets; those should be especially avoided which have moveable machinery in connection with the bowl, such as the pan, valve, and plunger closets. Some of these are very inexpensire, but they are objectionable, either because they rust and accumulate filth, or because they get out of order easily. The forms of closets without movable machinery in connection with the bowl, that is, in which the machinery is connected with the flushing cistem, such as the hopper, the siphon-jet, and the washout closets, are to be preferred. Any washout or hopper closet bought from a responsible firm is likely to give satisfaction, if thoroughly flushed and kept in order.

Stationary laundry tubs are of less importance than these other plumbing fixtures, since there are several excellent washing machines the 
use of which does away with the necessity for them. If one must choose between the two, the washing machine will be most useful; but if one wishes to have laundry tubs also, they come in porcelain, soapstone, granite, and wood, the latter being the least desirable.

If the water supply be limited, as when a tank is supplied by pumping from a cistern, the hot water boiler, the bath-tub, and the stationary washstand may be arranged almost as easily as when there is an abundance of water; but it may be necessary to substitute the dry-closet for the water-closet.

When no tank supply is available, and all water must be carried from a cistern or from the well in the yard, the cost of plumbing is very small and the discomfort rery great. Warm water must be supplied chiefly from a reservoir at the back of the range, thus making frequent bathing very inconvenient, even if a regular bath-tub be provided. If, however, a cesspool be built in the yard, the kitchen sink, the slophopper, the bath-tub, and the laundry tub may have waste pipes to it. Such waste pipes, save just half the work, for the water has to be carried only to the fixture, not away from it again. It thus seems worth while to have the fixtures, even though they serve only half their purpose. A slop-hopper with pipe to the cesspool, on the 
same level and near the kitchen, for waste wash water, etc., from the chambers, sares many steps, and is far more sanitary than throwing slops on the ground outside the house or carrying them to the outhouse.

The chief problem is the outhouse, or privy vault. There is no more disgusting or unsanitary feature of rural life than this ill-smelling, dirty hole in the ground, from which the filth permeates the surrounding soil, and may contaminate the water supply. Much discomfort and some digestive ills arise from the necessity - especially for women - of going a considerable distance in cold weather and at night, to such places. The closet should, therefore, be as near the house as is compatible with decency, and should be reached by a corered walkway. If properly built and regularly disinfected and cleaned, it need be neither disgusting nor unsanitary. The wooden house should never be papered nor carpeted, but should be painted or whitewashed yearly and kept scrupulously clean. The habitual use of ashes or dry earth in the receptacle and an occasional application of some disinfectant, such as copperas or chloride of lime, is necessary. If drawers are used in the priry, they may be hauled out frequently by horse; and with the liberal use of road dust, no offense arises. The writer knows a country 
house in which dry-earth closets are under the house-roof, and yet there is no umpleasantness. Since the well is so easily contaminated by the seeping through the soil of manure and human waste matter, it is of the utmost importance that the privy vault should be below the source of water supply and as far as possible from it. In the following pages the details of construction of the privy vault are given, the relative location of it, and the water supply.

Plumbing fixtures, like all other mechanical contrivances, to be efficient, require to be kept in perfect order. Frequent, thorough flushing with hot water whenever possible, and disinfection of the closet and the sink, are especially desirable. If all fixtures be set "open" and all pipes in sight, any leakage may be easily detected and remedied. If the pipes be painted with white lead, the defect will be discovered by the discoloration of the paint.

\section{WATER SUPPLY AND SEWAGE}

Water in abundance for the domestic animals should be provided by means of artificial pools or lakes, situated on land higher than the barns, but if they must be placed below the level of the buildings, aermotors or windmills may be easily made to elevate it to any reasonable height. It 
is difficult to explain why more miniature lakes, in which to store water for all except culinary purposes, are not constructed. In Fig. 7 it is shown how easily these pools may be made without expensive stone dams, and after the fashion of those constructed in many of the southern states.

Wells, in many places, must be deep, and then often furnish but a meager supply of water, while cisterns large enough to supply all wants are expensive. In addition to artificial lakes, wells, and cisterns, there are often streams, or best of all, springs, to be drawn upon. In any case, a full and continuous supply of water should be provided before buildings are constructed if annoyance, loss, and unnecessary labor are to be obviated and the best sanitary conditions secured in the house. Unless the water is brought into the house under a constant pressure, one or more storage tanks should be provided. They should be placed at such elevations as will secure at least some pressure on the first floor above the cellar. The storage tank may have a capacity of from one to five barrels, and may be constructed of rough or planed tro-inch planks and lined with galranized iron, if the water is to be used for culinary purposes; if not, it may be lined with lead. The tank, which may be of any shape desired, may be placed on sup- 
ports near the ceiling of the bath-room, or the room which contains the commode, or at one end in the upper part of the clothes-press; provided, however, that the discharge pipe is made so large that under no contingencies will the tank overflow. If the house is fairly large and the cistern capacious, sufficient water may be pumped into the tank from the cistern in a few minutes to supply all wants for the day. From the tank it will flow by gravity into the hot water boiler and to all other points desired which are not above the tank. If water be raised by means of an aermotor, a storage tank will still be necessary, as the wind may fail to operate the motor for an entire day. By whatever means water is secured, the supply should be ample at all times. Springs and wells in the middle and northern states, and cisterns in the southern states will, in most cases, serve to supply the potable water needed, but these are too often inadequate to supply the large demand for water made by the animals, and the extra demand for water in the house made by cleaner and more sanitary methods of living.

In using water in the household, it becomes mixed with a great variety of organic substances which pollute it, and which tend to putrefaction and decay. As these various organic substances break dorn, numerous compounds are produced, 
many of which endanger not only health but life itself; it is therefore evident that all soiled water should be removed from the house immediately and by the shortest practical route. But what to do with the polluted water after it has been removed from the rooms, becomes one of the most difficult problems of modern civilization. The first thought is to empty this sewage into streams and lakes; but those living on the streams and in the cities must secure their water-supply from these sources. It is evident, then, that the streams should not be polluted. The next thought is to distribute the sewage over the land, but this method is usually an expensive one, and seldom can enough sandy land be secured to absorb and filter the vast quantities of sewage which modern conditions make necessary.

On the farm the same difficulties are presented, and the problem to be solved differs in degree rather than in kind. If dry-earth closets are used on the farm, there is still the kitchen and laundry sewage to be provided for. While disposing of this, provision may also be made for the night-soil, thus obviating two systems of remoring waste from the house. Howerer, the earth-closet will reduce the amount of liquid sewage and increase the temptation to discharge it into the streams which, above all things, should be avoided. If porous or sandy lands can 
be found within reasonable distance of the dwelling, and ret not too near to it to endanger health or pollute the water supply, a cesspool may be constructed. A hole some ten feet in circumference and ten to twelve feet deep, dug in the earth, walled with stone without mortar, may serve for catching and filtering the sewage. On top of the wall, which should not reach the surface of the ground by about two feet, lay two pieces of railroad iron, and on these place large flat stones, covering all with dirt, providing, however, for ventilation by ineans of a 4-inch iron pipe, which should be long enough to reach a little above the surface of the ground when all is completed.

If the soil is not as porous as is desired, lay several tile or stone drains at a depth of three to five feet, and extend them from the cesspool some distance out into the field or grounds beyond. (Fig. 87.) These

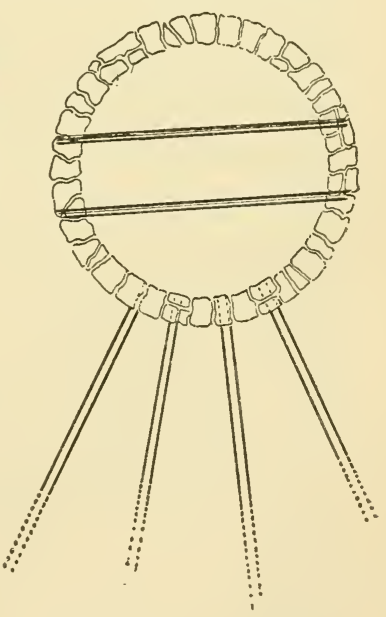

Fig. 87. Plan of a cesspool. drains should have free outlets, and the longer they are the better. At the outlet of the drains plant willows or some other water-loving, fast- 
growing trees. These will take up and utilize vast quantities of liquid and decomposed solids, and if the household is of only ordinary size no nuisance will result.

If water is limited and the dry-earth closet must be adopted, then the cesspool for the kitchen and laundry liquids need not be made so large as described, but may be built in the same manner. The dry-earth closet may be built as follows: Construct a privy of suitable size, 5 to 20 feet from the most convenient rear door, and connect it by a covered walk to the house. The small building should be placed not less than two feet above the ground, on a good, tight wall, which should extend under three sides of the building, the other side to be furnished with a hinged door. Secure a large, iron-top, dump wheelbarrow, which may serve to hold all foecal matter. This may be emptied weekly or monthly into a nearby trench, previously prepared. A few shovelfuls of earth thrown upon the excreta will effectually arrest any offensive odors which might otherwise arise. Before the ground freezes in the fall dig a trench of sufficient length to contain the foecal matter during the winter. In cold weather the barrow may be inverted over the trench, and by the application of a few quarts of hot water to the iron bottom the frozen material will be released. When the 
ground thaws, the accumulated matter may be covered. While the material is frozen there will be no danger from it. It should be said that this trench would better be dug near a row of trees or other strong-growing perennial plants. These will quickly take up the products of the night-soil which might, in rare cases, tend to contaminate the soil-water. If but little of the night-soil be deposited in one place, the earth and plants-two most efficient disinfectants-may be trusted to preserve good sanitary conditions. However, pains should be taken to discover if, by any possible means, the sewage may find its way into the well. An intelligent inspection of the soil, the stratification of it and the rocks, will reveal the direction which the soil-water takes; but if the cesspool and the drains are placed some distance from the dwelling, no contamination will take place under any circumstances, since the amount of sewage is so small and the power of plants and soil to take up the dangerous products of sewage is so great. 


\section{CHAPTER XIII}

HOCSEHOLD ADMINISTRATION, ECONOMY, AND COMFORT

Is colonial times, before so many of the household operations were transferred to shops and manufactories, women were producers almost as much as men; but in modern times women are more and more concerned with how money shall be spent. The woman is still a producer when she cooks an egg, mends a garment, or sweeps a room; but the question of how much or how little can be had out of the family income has become relatively more and more her concern. In Europe, far more than in the United States, attention is given by the women to the economical expenditure of the family resources. A provincial French girl is trained from her childhood for household duties. She assists her mother not only in order to learn the finer arts of housewifery, but especially the judicious expenditure of money. The French husband leares the apportionment of the family income almost wholly to his wife's discretion. 
There can be no doubt that the prosperity of the family depends quite as much on the wise use of the income as upon the size of that income. The first essential of good household management is that the housewife should know definitely how much there is to spend. Nothing is more productive of marital discontent than the habit which many husbands have of doling out money to the wife at irregular times and in indefinite amounts. It destroys the wife's selfrespect, it places her in a degraded position before her children, and it removes all incentive to thrift. It not infrequently supplies a powerful motive for deceit. If the wife is inexperienced, unwise, or extravagant in the use of money, so much the more reason why the husband should patiently and firmly teach her how to spend, both for her own sake and that of the family welfare. An arrangement by which the wife controls the expenditure of a certain portion of the income is very easy whenever the man receives a salary or regular daily wages. A regular income tends to develop thrift and to teach people to avoid debt; but there is always a tendency to live up to the limit of it, and the margin for saving and for extra pleasures is always small. Salaried people seldom get deeply in debt, but they as seldom become very rich. On the other hand, whenever the family in- 
come is irregular, as from farming and most other kinds of business, the problem of household financiering is much more difficult and requires both greater self-control and better judgment. It is usually possible for such families to determine upon a definite minimum amount which may be counted upon for ordinary living expenses. The margin above this may vary widely, but if the scale of living be habitually adjusted to come within the minimum income, there will be no terror of debt. The expenditure of the surplus, when it comes, becomes a unique and unexpected pleasure. Whatever the plan adopted for distributing the family income, the wife should have at her command and should be expected to live within, a definite share of the income.

After the minimum expenses of the family have been determined, the next most important question is how and when they shall be paid out. Cash payments are much to be preferred. They have two adrantages: whoever pays cash asks no favor of the tradesman, and commands the best quality at a given price. The tradesman who lends money by allowing the payment of bills to be postponed, must pay for his goods and must have interest on the money necessary to carry on a credit business. He must necessarily, therefore, reimburse himself by charg- 
ing a higher price, or by giving a poorer article. It should never be forgotten that credit costs something. The cash customer is always considered a good customer, and can always have the first choice of the market, and favors if any are desired. Whenever monthly or quarterly bills are run, the debtor is apt to acquire a most dangerous habit-the habit of spending now, to pay at some future time. The more remote the time, the more dangerous the habit. It is evident that the oftener bills are paid, the less likelihood there is of mistakes and deceit. If bills must be run, it should never be for longer than a month, and prompt payment of them is a solemn obligation. The article should be done without rather than the seller asked to wait for his money. Whatever plan the housewife adopts will be conditioned by the customs of the locality in which she lives and by the habits of the local tradesman.

Women waste much time and energy in buying things one by one; they spend in this way, too, much more than they realize, and then they wonder where the money has gone. China, linen, and the stock of clothing necessary for changes of season, should be bought by the set, or quantity, marked and prepared for use at regular intervals. Women buy a collar or two, a pair of stockings, a bit of ribbon, a bread 
plate, a few glasses, etc., and then are surprised that they seem to have rery little for the money. Unless the housewife be really poor, or unless the money be doled out to her irregularly, it will invariably pay to buy in quantity things which are not perishable, and which the household wear's out and, therefore, habitually needs. Handkerchiefs, stockings, underclothing, china, drinking glasses, cost less by the dozen and half-dozen than by the piece. Lamp chimneys are continually broken, toilet paper and soap used up, yet very few housekeepers realize that they waste both time and energy, beside suffering inconvenience, when they buy these one at a time. Buying piecemeal is demoralizing, as well as wasteful, because it is unsystematic. Successful housekeeping involves attention to numberless details; if by periodic instead of incessant attention some of these can be disposed of in the mass, there will be immense saving of energy.

Many housekeepers will object to this, either because it involves the immediate expenditure of a larger sum of money for one class of articles, or because, not having more wholesome social and intellectual interests, they find recreation in wandering from store to store, or counter to counter, pricing much and buying little; or because they love to find "a bargain." The in- 
stinct to get something "cheap," that is, to get something for nothing, or, more properly, to get more than we pay for, lies rery deep in human nature. Because women have usually lived from hand to mouth, without foresight, it has perhaps been exaggerated in them. There are the bargain-hunters, and there are the bargainscorners; both are doubtless equally illogical. When an article is phenomenally cheap, it is so, usually, either because too many of its kind are on the market, or because the seller is sacrificing a normal profit to draw general custom, or because the people who have produced it have done so at less than a decent living wage, or because it is going or gone out of fashion. Good buyers are rightfully suspicious of bargains. No one should be willing to buy or use articles which have been produced at starration wages under wretched sanitary conditions. It is never good economy to buy things which are gone out of fashion unless one is quite satisfied to be out of fashion. If the article offered on the bargain counter be of good quality, and in staple use in the household, it is often well worth buying. Flannels, linens, sometimes woolen dress goods of inconspicuous patterns, may be bought at the end of the season much cheaper than at the beginning, and are a good investment if one has money to spare and is 
sure what is going to be needed by the family. Over against the money saved in securing a bargain, must always be reckoned the time and energy used in finding it, and the risks that its quality may prove inferior, or that it may be unsuitable when finally used. If a woman has nothing better to do with her time and strength than to hunt bargains, there is nothing further to be said; but if she has, it is usually more economical and more satisfactory to buy the articles needed for definite use at a reliable place and at a fair price.

All the suggestions that have been made imply accurate knowledge on the part of the housekeeper. A thoroughly trained housekeeper of long experience may possibly keep all the household detail in hand withont keeping books of account, but it is absolutely impossible for the inexperienced or unsystematic housekeeper to do so. The mental training involved in keeping an accurate account of family income and expenditure is as valuable as a course in mathematics. For her own self-discipline, as well as for the better distribution of the family income, every housekeeper should keep an itemized account. Until she can balance her account accurately at the end of every month she has not learned the $a$ b c of thorough housekeeping. After having learned to do this easily, she may, 
perhaps, allow herself a very small margin for those "sundries" which have not been put down, and which would waste valuable time to hunt out. Every housewife knows by experience that it is not the regular meat and grocery bills that eat up the income; if adequate care is taken of them, they can be reduced to a definite scale and kept there; but it is the incidentals. A system of accurate accounts will speedily show how many of these are extravagant or umnecessary. Book-keeping is a bugbear to most women, chiefly because the system which they undertake is too complicated. The simplest form is the best. Any blank book may be used; put down on the right hand side everything bought; on the left side all money received; at the end of the week or month the total sum of the righthand column plus the money still on hand should equal the total of the left-hand column. If it does not, some item has been omitted or not accurately entered. It is better in the beginning to balance the account at least once a week, for then inaccuracies can be more easily traced. The secret of success is to put down at the time of the transaction what has been received and spent. When the account has been balanced, a second step is much more interesting. In another book or in the back of the day-book, if it be large enough, open several 
accounts on separate pages, as follows: groceries, meats, fuel, clothing, subscriptions and charities, incidentals, etc. Copy each item from the day-book into its proper account; at the end of a month or year, by adding up these separate accounts, the housewife can tell exactly what proportion of the income has been spent for each class. Mr. Lawes, the famous English agriculturist, when traveling in America, was able to quote accurately the cost of the various items of expenditure in his own house.

Economy is a relative, not an absolute thing. Economy of money is often wastefulness of life, yet extravagance, on the other hand, is a serious cause of human degeneration. With the exception of poor management, poor service is probably the most wasteful factor of all in the household, yet there are conditions in which poor service is certainly less wasteful of the family resources, than none at all. The end of housekeeping is the health, comfort, and serenity of the family. The two main factors in producing this result are the family income and the mother's strength and energy. Saving, however desirable, is merely an incidental end. The mother's intelligence, therefore, if she be in command of her fair share of the income, must be used to save not only money but her own resources. The lack of nutritious, palatable 
food and of nursing in illness, the lack of service when the mother is weakened by labor and child-bearing, is sometimes economy with most disastrous results. Health and serenity are worth more to the family than houses and a bank account. A good education given to an intelligent child is worth ten times its cost saved up for him to inherit in middle life.

Every device, therefore, which saves the housewife's energy is a true economy. A clotheswashing machine, a cabinet table, a slop-hopper for kitchen and chamber waste-liquids, are all obtainable and of special value in saving labor. In planning the kitchen, economy of steps in reaching water and fuel should be considered. China should be kept either in wall cupboards opening on one side into the dining-room, on the other into the kitchen, or in a pantry between dining-room and kitchen. Kitchen utensils need no longer be of black, heary, ugly iron, but of granite ware, nickel plate, and aluminum; they may be placed in shelves close to the range, or hung along the wall beside it. A dumb waiter or hand elevator, from kitchen to cellar, saves much going up and down stairs. The height of sinks and work-tables should be adapted to that of the woman who works over them. A tall stool-a clerk's stool - in the kitchen allows the housewife to sit while doing 
some kinds of work. Distances between sink, range, dishes, and store-room, should be as short as possible, while the ventilation and lighting of the kitchen should be particularly good. Every step up and down from kitchen to shed, or kitchen to cellar, is an extra drain on the orertaxed woman. Small, cheap contrivances, such as dish-mops, iron dish-cloths, panscrapers, small scrubbing-brushes, wire screen garbage-pans, and many others, lighten the work and make it possible for the housewife to be more dainty in her personal appearance.

In no respect does farm life differ more from city life than in the kind of food provided and the method of serving it. The farmer's table is loaded down with a great abundance and variety of food, all placed on the table at once, and often rich and indigestible. The city table has half as much, both in variety and quantity, served daintily in courses. The city housewife provides variety from meal to meal, seldom repeating any dish, except the staple ones, more than once or twice a reek; the rural housewife puts a large variety of the same things on the table at every meal. Abundance of well cooked, appetizing food there should be, but variety from meal to meal, and from day to day, is far preferable to excessive variety at any one meal. Not only is it better for the digestion to eat of 
a very few kinds of food at one meal; but, since novelty stimulates appetite, any particular dish will be more appetizing if not served too frequently. The farmer's family, while very economical in the expenditure of money, is often very wasteful of food. Tegetables, fruit, chickens, pork raised on the farm, seem to cost no money, but they cost much vital energy, which is quite as valuable. The value of milk, butter, and eggs is recognized, because it is customary to sell them in town; but the cost in the labor of those who raise and those who prepare food, is often overlooked. The farmer's table is thus not only overloaded, but really extravagant. Here, again, quality is more desirable than variety; simplicity should accompany abundance.

Since rural life involves a certain degree of isolation, the family must keep in touch with the world chiefly through literature. Even at the sacrifice of some of the rich variety of food on the table or of new clothes, books and papers should be provided. The local newspaper is apt to contain little beside local gossip; it should be supplemented with an agricultural paper and a family journal, a housekeeping magazine, a children's magazine, if there be children, and other general magazines if they can be afforded. But better than the general magazines, would be the gradual purchase of the standard works of his- 
tory, travel, poetry, and fiction. A musical instrumeni, a small library, and interesting games will do more than admonition to keep young people at home. Children naturally want a good time; if it is not provided for them at home they will go to other and perhaps less desirable places to get it.

With the increase of appliances, and with the added social and intellectual demands, country as well as city life is becoming more complicated and exacting. The housewife, whose physical strength is scarcely equal to the demands of housekeeping and child-bearing, must derelop her intelligence and whet her judgment. She must find easier and wiser ways of doing the necessary drudgery, and make brains do an increasing part of the labor formerly accomplished by muscle. 


\section{CHAPTER XIV}

\section{THE HOME YARD}

THE yard, as well as the house, should be planned. It should be convenient, neat, handsome, restful. It will need planting with trees, shrubs, herbs and grass; but these things should not be scattered promiscuously over the place, for then they mean nothing. Every plant should have some relation to the general plan or design of the place.

The first thing to consider in the making of a fit setting for the house is to lay out the plan $\mathrm{or}^{\circ}$ design; the last thing is to select the particular kinds of plants to be used. The place should be a picture. It should be one thing, not many things. If the design is correct and the planting is well done, all parts will be in harmony and the place will appeal to one as a whole. If the bushes and trees are scattered promiscuously over the yard, then there is no central idea and the attention is fixed upon the details rather than upon the place. Figs. 88 and 89 illustrate these contrasts.

The one central thought or idea in home 
grounds is the house. Therefore, make the house emphatic. Let it stand out boldly, as in

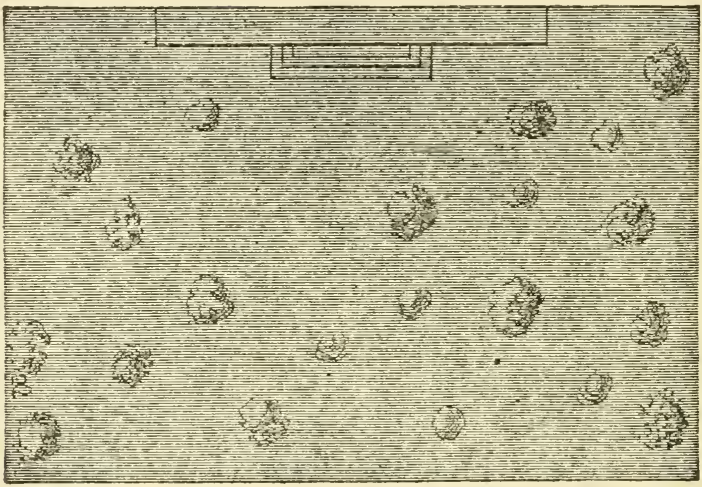

Fig. 88. The common or nursery type of planting.

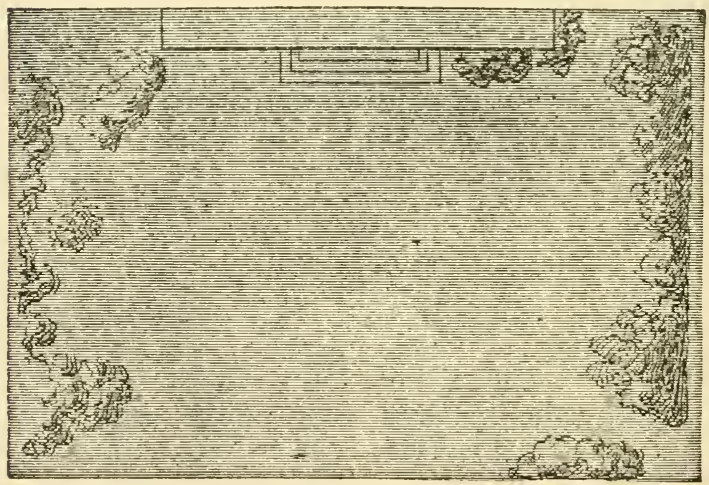

Fig. 89. The proper or pictorial type of planting.

Fig. 89. Keep the center of the place open. Do not clutter it with trees, flower beds and other distracting things. 
If the house is to be made emphatic, give it a flanking. Plant trees or bushes, or both, on the sides. Back it up, also, with trees. If it sets in front of a natural rood or an orchard, the effect is better. If the country is bare and bald behind it, plant tall trees there. Make as few walks and drives as possible. They are always unsightly and expensive. Let them lead to their destination by the most direct curres. Do not make them crooked; for crooked walks and drives are expensive. Gentle curves are more retired and modest than awkward and laborious ones. Fig. 90 shows a good, easy curve. If possible, place the walk or drive at the side, rather than in the center: aroid cutting up the lawn.

Most of the planting should be in masses. Plants present a bolder front when standing together. A group is one thing; scattered shrubs are many things, and they divert and distract the attention. By massing, one secures endless combinations of light and shade, of color, and of form. Against the mass-planting, flowers show off best; they have a background, 
as a picture has when it hangs on a wall. One canna or geranium standing just in front of heavy foliage makes more show than do a dozen plants when standing in the middle of the lawn; it is more easily cared for, and it does not spoil the lawn. A flower bed in the middle of

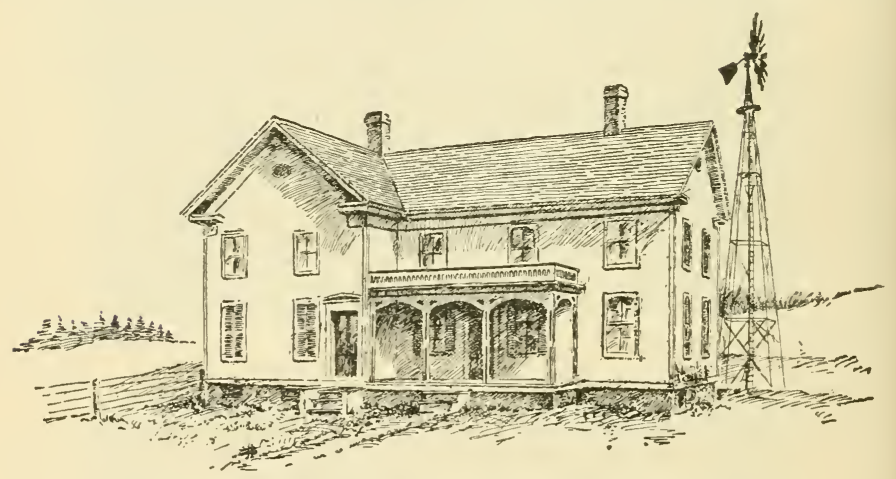

Fig. 91. A good house; but the home is only half built.

the sward spoils a lawn, as a spot soils the table-cloth. Flowers at the side, or joined to the other planting, are a part of the picture; in the middle of the lawn they are only a spot of color and mean nothing except that the grower did not know where to put them.

Take these suggestions to heart. Consider which you like the better, Fig. 91 or 92. Consider, also, how Fig. 92 would look if plants were scattered all over the yard.

Plants are difficult to grow in little holes in 
the sod. The grass takes the moisture. They are always in the way. The yard in Fig. 92 can be mown with a field mower. The bushes take care of themselves. If one dies, it matters little: other's fill the gaps. If pigweeds come up amongst them, little or no harm is done. They

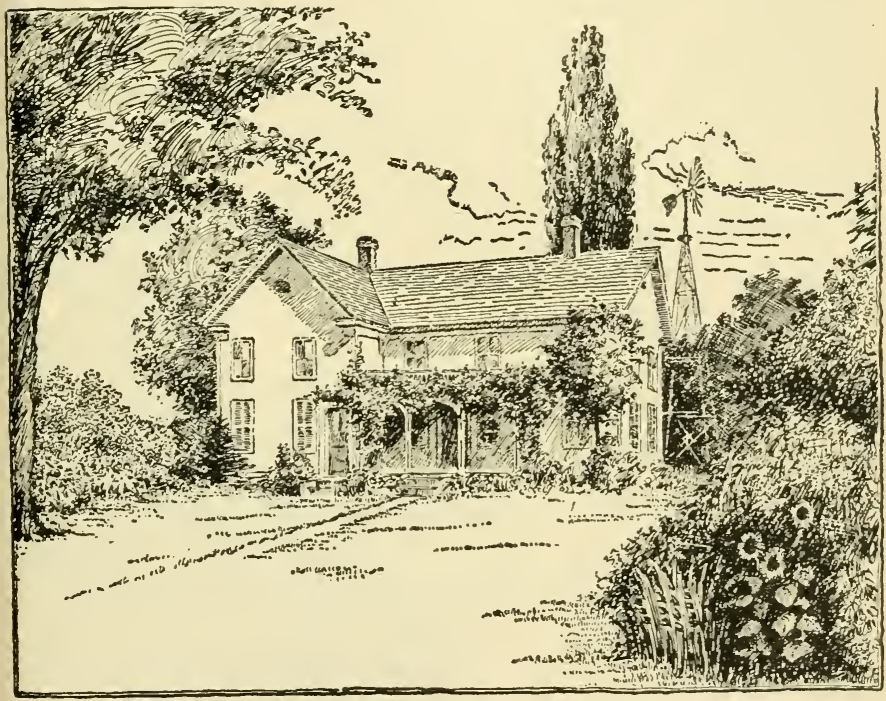

Fig. 92. A house and a home.

add to the variety of foliage effect. One does not feel that he must stop his cultivating or sheep-shearing to dig them out. In the fall, the leaves blow off the open lawn and are held in the bushes; there they make an ideal mulch, and they need not be removed in the spring. In 
front of this shrubbery a space two or three feet wide may be left for flowers. Here sow and plant with a free hand. Have sufficient poppies and hollyhocks and pinks and lilies and petunias to supply every member of the family and every neighbor. Against the background they glow like coals or lie as soft as the snow.

Fill in the corners of the place. Round off the angularities. Throw a mass of herbage into the corner by the steps (Fig. 93): then you will not need to saw off the grass with a butcher knife. Plant a vine and some low plants along the foundations.

When these main or fundamental things are considered, then some of the incidental things may be considered. If you are fond of some particular plant, as the hydrangea, plant it in some prominent place in front of the shrub border. You may want a tree to shade a

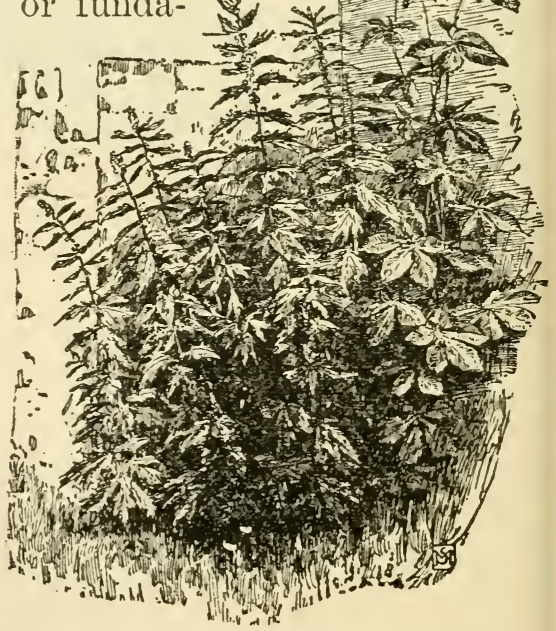

Fig. 93. The corner by the steps. 
window or a porch: plant it. You may want a pile of odd stones and relics: put them in the back yard, or at the side, where you may enjoy them unmolested. You may have any kind of plant you want, only put it in the right place.

Have an eye to the riews. Build your house with reference to them, if you can. Do not plant so as to hide the good ones. Plant heavily in the direction of offensive views. Plant so as to obscure the barnyard; or else move the barnyard back of the barn, or clean it up. Leave the front of the barn open: you want to see it from the house.

HOW TO DO THE WORK

The lawn, then, is the first consideration. It is the canvas on which we are to paint a picture of home and comfort. In many cases the yard is already level or well graded and has a good sod, and it is not necessary to plow and re-seed. It should be said that the sod on old lawns can be renewed without plowing it up. In the bare or thin places, scratch up the ground with an iron-toothed rake, apply a little fertilizer, and sow more seed. Weedy lawns are those in which the sod is poor. It may be necessary to pull out the reeds; but after they are out the land should be quickly corered with sod or they will 
come in again. Annual weeds, as pigweeds and ragtweed, can usually be crowded out by merely securing a heavier sod. A little clover seed will often be a good addition, for it supplies nitrogen and has an excellent mechanical effect on the soil.

The ideal time to prepare the land is in the fall, before the heavy rains come. Then sow in the fall, and again in early spring on a late snow. However, the work may be done in the spring, but the danger is that it will be put off so long that the young grass will not become established before the dry, hot weather comes.

The best lawn grass for New York is Junegrass, or blue-grass. Seedsmen know it as Poa pratensis. It weighs but 14 pounds to the bushel. Not less than three bushels should be sown to the acre. We want many very small stems of grass, not a few large ones; for we are making a lawn, not a meadow.

Do not sow grain with the grass seed. The June-grass grows slowly at first, however, and therefore it is a good plan to sow timothy with it, at the rate of two or three quarts to the acre. The timothy comes up quickly and makes a green; and the June-grass will crowd it out in a year or two. If the land is hard and inclined to be too dry, some kind of clover will greatly assist the June-grass. Red clover is too large 
and coarse for the lawn. Crimson clover is excellent, for it is an annual, and it does not become unsightly in the lawn. White clover is perhaps best, since it not only helps the grass but looks well in the sod. One or two pounds of seed is generally sufficient for an acre.

At first the weeds will come up. Do not pull them. Now the lawn as soon as there is any growth large enough to mow. Of course, the lawn-mower is best, but one can have a good place without it. Perhaps a hand lawn-mower (one with large wheels and not less than 16-inch cut) can be used to keep the sward close just about the house; then the field-mower may be used now and then for the remainder. Here is another advantage, as I have said, of the opencentered yard which I have recommended; it is easily mown. It would be a fussy matter to mow a yard planted after the fashion of Fig. 8s; but one like Fig. 89 is easily managed.

The borders should be planted thickly. Plow up the strip. Never plant these trees and bushes in holes cut in the sod. Scatter the bushes and trees promiscuously in the narrow border. In home grounds, it is easy to run through these borders occasionally with a cultivator, for the first year or two. Make the edges of the border irregular. Plant the lowest bushes on the inner edge toward the house. 
For all such things as lilacs, mock oranges, Japan quinces, and bushes that are found along the roadsides, two or three feet apart is about right. Some will die anyway. Cut them back one-half when they are planted. They will look thin and stiff for two or three years; but after that they will crowd the spaces full, lop over on the sod, and make a billow of green. Prepare the land well, plant carefully, and let the bushes alone.

We now come to the details, - the particular kinds of plants to use. One great principle will simplify the matter: the main planting should be for foliage effects. That is, think first of giving the place a heavy border-mass. Flowers are mere decorations.

Select those trees and shrubs which are the commonest, because they are cheapest, hardiest and most likely to grow. There is no farm so poor that enough plants cannot be secured, without money, for the home yard. You will find the plants in the woods, in old yards, along the fences. It is little matter if no one knows their names. What is handsomer than a tangled fence-row?

Scatter in a few trees along the fence and about the buildings, particularly if the place is large and bare. Maples, basswood, elms, ashes, buttonwood, pepperidge, oaks, beeches, birches, 
hickories, poplars, a few trees of pine or spruce or hemlock,- any of these are excellent. If the country is bleak, a rather heavy planting of evergreens about the border, in the place of so much shrubbery, is excellent.

For shrubs, use the common things to be found in the woods and swales, together with roots, which can be had in every old yard. Willows, osiers, witch-hazel, dogwood, wild roses, thorn apples, haws, elders, sumac, wild honeysuckles, - these and others can be found in abundance. From old yards can be secured snowballs, spireas, lilacs, forsythias, mock oranges, roses, snowberries, barberries, flowering currants, honeysuckles, and the like.

Vines can be used to excellent purpose on the outbuildings or on the porches. The common wild Virginia creeper is the most serviceable. On brick or stone houses the Boston ivy or Japanese ampelopsis may be used, unless the location is very bleak. This is not hardy in the northern parts of the country. Honeysuckles, clematis and bitter-sweet are also attractive. Bowers are always interesting to children; and actinidia and akebia (to be had at nurseries) are best for this purpose.

If a regular flower garden is wanted, place at the side or rear of the place, where a liberal piece of land can be devoted to it. 
Into these native shrub borders, throw some color from nursery-grown bushes if you choose. Mix in spireas, weigelas, roses - anything you like. A rare or strange plant may be introduced now and then, if there is any money with which to buy such things. Plant it at some conspicuous point just in front of the border, where it will show off well, be out of the way, and have some relation to the rest of the planting. Two or three purple-leaved or variegatedleaved bushes will add much spirit and verve to the place; but too many of them make the place look fussy and overdone. You can have a botanic garden of your own, even though you do not know the name of a single plant; and your home will be a picture at the same time. 


\section{CHAPTER XV}

\section{A DISCCSSION OF BARNS}

Modern agriculture requires large and commodious barns and other structures to house the crops, the animals, tools, and implements. Especially is this true when mixed farming is conducted in an intensified and economical way. In early days one or, at most, two low barns of 30 by 40 feet were supposed to supply all shelter accommodations required for a farm of one hundred acres. At the present time, on the same farms, may often be seen a barn 60 by 80 feet and double the height of the old structures, with a wing one-half of the capacity of the main barn to which it is attached, this single structure providing more than six times the cubic space of two of the old barns. One sizable farm in Tompkins county, New York, had, for many years, a single barn 30 by 40 feet with 14 -foot posts. It now has a barn which provides more than fifteen times the room of the old one, and yet it is scarcely large enough to house the animals and crops of this modest farm. 
Naturally, the questions arise, are these large structures necessary, and what changes in agriculture have taken place to create a need for such mammoth structures? They are necessarily expensive, and too often dwarf and belittle the house when placed near it.

Modern advanced farmers secure nearly or quite double the average yield of crops of their grandfathers. This is an indisputable fact, notwithstanding the hue and cry about the decadence of the rural population. The facts are that some are farming much better than the older generations and some much Torse. Much of the good land is producing more bountifully than ever before, and some of the poorer lands have been so badly managed, and have become so depleted in their productive power as to be nearly worthless, and should be thrown out of cultivation and left to recuperate until unborn generations require them. More live stock is kept now than formerly. The number of milch cows, horses, and mules in the United States increased more than 50 per cent between 1870 and 1890, and other cattle increased during the same period 150 per cent. Notwithstanding this fact, the live stock on many farms has been greatly diminished.

Then, too, progressive farmers believe it to be economy to provide shelter for animals and 
crops, manures and implements. The old custom of stacking the hay and grain, of allowing the farm animals to toughen in the winter's blast in field and barnyard, and the manures to leach and bleach under the eaves of the building has, in part, been abandoned and better methods substituted. These new methods require better, larger, and more commodious farm barns. The modern and humane thought is, to make all of the animals as comfortable, according to their needs and conditions, as is their owner in his well appointed house, and to protect everything that is worth protecting from the storms.

There are two fairly distinct methods of constructing farm buildings: the concentrated and the distributive. The one aims to provide the room needed by one or two large structures; the other by means of many detached small buildings, each, where practicable, devoted to a special purpose. The last method was the outgrowth of the conditions which usually prevailed in a new country. First came the rude house and the log stable. The stable was followed by the modest barn, usually of the regulation size, 30 by 40 feet, with 12-, 14-, or, in rare cases, 16-foot posts. As the arable land increased another barn was built, then a shed, then a wagon-house; followed by a corn-crib, a chicken- 
house, a pig-pen, and later a sheep-barn, cowbarn, a hay-barn, all the room in the first and second barns being by this time required for grain. Outside the grain districts the buildings were modified to suit conditions, but the practice of constructing many small structures was not changed.

The buildings were erected without any comprehensive plan as to the farmstead as a whole. This necessitated many fences, gates, yards, and a maze of muddy byrays in which the dock and other weeds, discarded implements, and the flotsam and jetsam of the farm found opportunity to grow or to rot. Do what one might, the farmstead could never be made to look neat and tidy. Not infrequently, twelve to fifteen separate structures may be seen on a farm of eighty acres. The farmers who own these structures are not to be criticised too severely. They inherited the method of building and often the buildings, and no one, so far, has deigned to give them help by treating such plebeian subjects as the improvement of unsightly stys, stables, sheds, and barns.

If the concentrated method be adopted, in case of fire all is swept away; if the distributive, some of the buildings may be saved. There are so many things to be gained, however, by adopting the concentrated method that 
construction would better be along this line and then trust to the insurance company to make good the losses by fire, should any occur. Compar'e Figs. 114, 119.

Farm laborers receive fully double the rages, except in harvest time, which they did fifty years ago ; therefore, the barns should be planned with the view of economizing labor. This can best be secured by rearing a single structure, rather than several, for it is evident that if the live stock, tools, implements and provender be placed in juxtaposition, economy in performing the work about the buildings will be secured. However, it is often convenient to have a separate building open on one side for storing farm wagons and heavy implements and tools.

Grain, hay and stover are all unloaded most economically by means of slings and hay fork, operated by horse-power, but the unloading by horse-power implies high barns, with mows measurably unobstructed by timbers. Economy of space also implies deep mows, since a mow twenty feet deep holds more than two mows ten feet deep. High, large buildings require far less outside boarding and roof than small, low, detached buildings which contain, together, the same storage capacity. Economy in construction and maintenance, convenience of temporarily sheltering and removing manures, ease of 
carrying on work in the building, and beauty, all indicate the wisdom of adopting the concentrated method in the construction of farm barns.

Efforts have been made to economize in barn construction by adopting the octagon form. This form secures a greater enclosed area for a given surface covering than the square or rectangular form. But all of the angles in the frame are more expensive to make than are right angles. It requires more labor and time to saw off a timber at an angle of 35 degrees than at right angles. True, this form lends itself to a roof structure free from obstructing timbers, but, on the other hand, it does not give opportunity for the placing of convenient tracks for elevating the provender. So far the pros and cons may be said to balance. It is only when the attempt is made to divide the octagon structure into stables and rooms, compartments and mors, that its inconvenient shape is fully realized. Everything is out of square. The divisions form obtuse and acute angles, or ares of a circle, almost without number: All this implies extra expense in the internal construction and usually a great waste of space. The illustrations of these barns have a certain charm difficult to resist, but some of the most intelligent farmers who have made a study of the octagon 
barn and have used it, decide that rectangular barns are much to be preferred. Some who have built octagon barns speak well of them, but this might naturally be expected. A moman generally speaks mell of her husband after she has secured him, hotrever faulty he may be.

\section{LOCATION}

The location of the proposed structure should be considered with the most painstaking care before entering upon the construction of a new building or the remodeling of an old one. Too often a single idea dominates the location. Some thirty years since I decided to erect a large basement barn. The house, a modest, comfortable structure, was located at a suitable distance from the highway, on a gentle slope. To utilize the highway for driving the animals to and from pasture, and to save the use of the fourth of an acre of land and the building of some twenty rods of fence, the barn was located nearer the highway than the house. This necessitated locating the barnyard between the highway and the barn. I never discovered this foolish mistake till years afterwards, when age and study had improved my judgment and opportunity had been given for wide observation and comparison. Now when I revisit the farm it is 

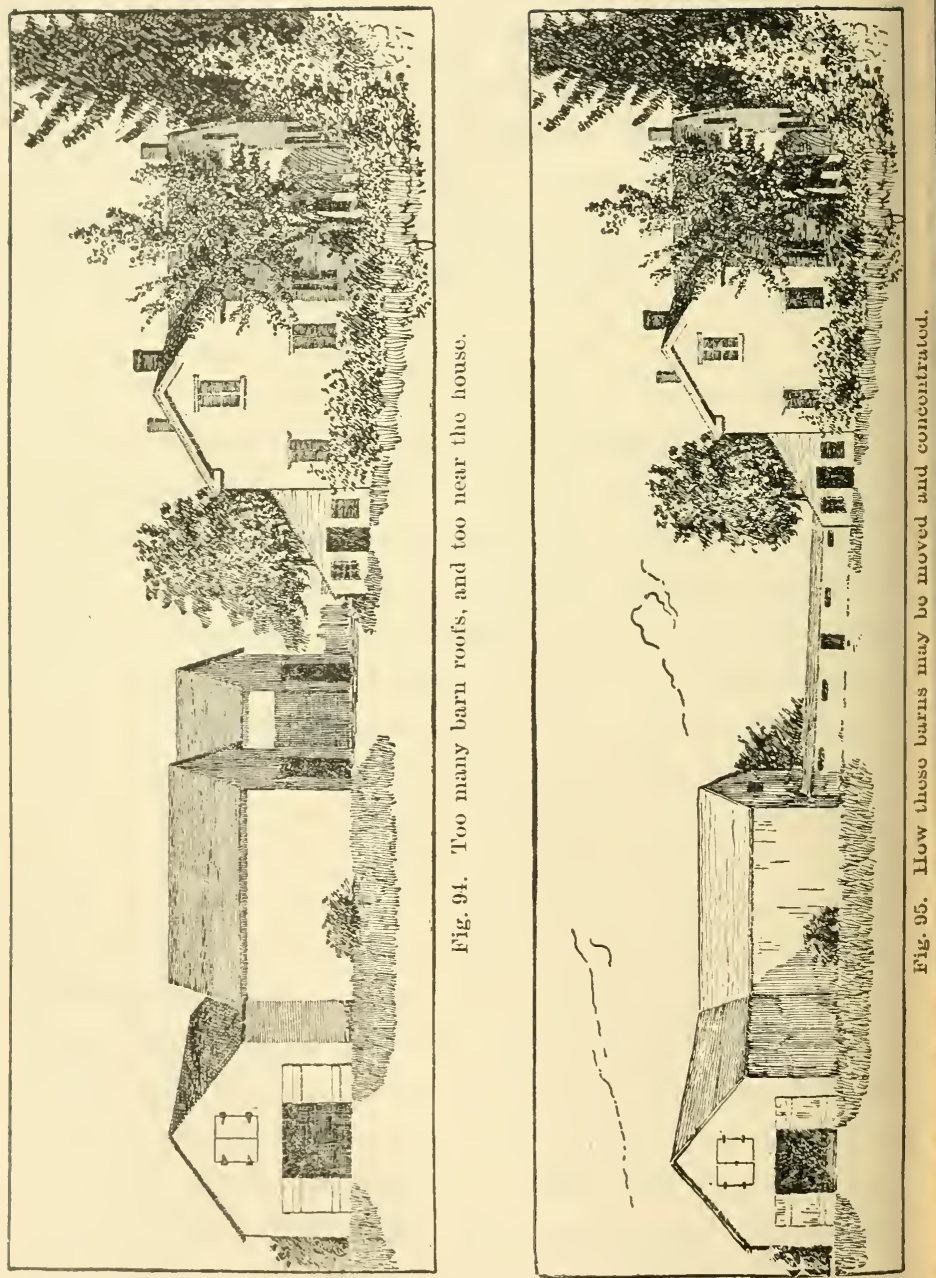
all too plain as to where the barn should have been located. This large barn made the house appear much smaller than before, and from one approach the farm had the appearance of being untenanted, as the barn hid the house. It is humiliating, but how could I have known better at that time of life, with ideas of barn building inherited and with neither book nor teacher to guide me?

The barn should be located far enough from the house to prevent the aromas of the stables and kitchen from mingling, and at such a distance as not to seriously endanger either one, if the other should be destroyed by fire. If possible, the barn should be on lower ground than the house, that no wash or seepage from it may tend toward the house, and for other sanitary reasons. The lower level will assist to make the barns inconspicuous. One hundred feet is the minimum distance which should intervene between these inflammable and expensive structures, except in a very cold climate, where the house and the barn may be connected by a covered way. See Figs. 94 and 95. This way need not be expensive, and should be so constructed that it can be pulled down in a few minutes in case of fire. It need not be high, and the roof might pitch but one way and be composed, in part at least, of glass. If the entire roof was of glass 
one side of the covered walk might well be used in the spring for growing early vegetables. If the manure be properly cared for at the far end of the barn, good sanitary conditions would be preserved.

The refuse of the stables, if left exposed at the barns in the summer, forms breeding ground for flies, which reach the house if it be near. The substitution of electric street cars, for horse cars which necessitated numerous stables, has noticeably diminished flies in the cities. There should be room between the house and barn for a score or more of large trees, which may serve, in part, to screen each building from the other in case of fire, to shade the walk between the two buildings, and, in part, the barn itself. No tree is better adapted for this purpose than the white elm. The open barnyard should, wherever possible, be discarded, for it tends to increase the wasting of manures and the cost of getting them to the field; to the multiplication of fences and flies, and to unnecessary exposure of animals. Why not substitute paddocks or small fields of a few acres for the wasteful, expensive barnyard? If the animals need exercise they should take it at suitable times in closely-sodded fields, or covered yards, rather than in confined barnyards filled with a mixture of straw, mud and manure. A few 
acres near the barn might be surrounded with a woven wire fence, which would serve admirably for an exercising yard. The sod on this small area might become seriously injured in a year or two, but the field would be enriched by the droppings of the animals. The field in such case could be plowed and the wire used to enclose another paddock. But it will be many years before the open barnyard can be, or will be, entirely abandoned. What may, and should be done immediately, is to place it at the rear, instead of at the front of the barn, and to cease using it for baptizing manures, and as a storage area for miscellaneous odds and ends. If some change is not made, the farm boy may find a chamber window from which a more restful and inspiring view may be secured than from the one through which he now views daily the evidences of thriftlessness and waste.

\section{PLANNING THE BARN}

Make a good study of many barns at short range; note what features are good, what faulty, what useless; by this means much will have been learned and many mistakes will be aroided. Decide approximately the capacity which will be required. First, draw a rectangrular diagram of the barn, then proceed to 
the proposed location and take a seat; make a most careful study of the approach, the incline of the land, note where fences and gates will be necessary, where and how the water is to be introduced - in fact, take in the whole problem of the environment of the proposed structure. Then imagine that you see the barn, and that you have just arrived from town some stormy night with your wife and baby; in imagination help them out of the carriage. Imagine you have a span of young, restless horses which you have driven to get them used to city ways before selling them. That will make you think of a platform onto which the family may step from the carriage while you are holding the colts. Consider how many big doors you will have to open before the colts are made comfortable for the night. Are the democrat wagon and the colts to be kept on the same floor, or one up-stairs and the other down? $\mathrm{Or}^{\mathrm{r}}$ is the carriage in one building situated four rods from the horses? How many gates and doors have you opened and closed since you arrived? Think it all over, and then go to the house and talk it over with your wife, for some day she may drive to town, and on her return find that both you and the farm hands are in the field, and that there is no one to help her put the team away. After imagination has pictured the 
conditions which are likely to prevail, then begin to cautiously modify the rectangular diagram; surround it with dotted lines, which may represent roads, fences, gates, lanes, and adjunct buildings. Then take a rest; lay the sketch away for a time; study barns in the neighborhood; council with the wife again, for she may have to go to the barn often. After a year of faithful and intelligent planning you may be able to place a well digested rough sketch of the proposed structure in the hands of a draughtsman.

\section{WATER SUPPLY}

It would seem to be unnecessary to repeat the axiom, "No water, no plant or animal life," but so many buildings, both public and private, are located and constructed before the problem of supplying an ample, perennial supply of potable water is solved, that it seems necessary to briefly treat this subject.

Several public institutions with which I have been familiar have erected expensive structures before supplying water for them. Three and sometimes five separate attempts were made to furnish water for the use of the plant, none of which were entirely successful.

The amount of water needed and the conditions under which it must be secured are so 
variable that few specific directions can be given. One simple, certain and cheap way of securing water for the barn is usually neglected. In some sections of the South, by reason of peculiar geological formations, the practice of constructing pools or storage reservoirs has become common. A slight depression or draw or swale is selected and dammed by using the earth from the bottom of the proposed pool and from the higher land adjoining. No stone or wood is necessary to support the dam. The only precaution necessary is to have a broad base (see Fig. 7), and to provide sufficiently large outflows or spillways, one on either end of the dam, that the pool may never rise higher than within two feet from the top of the dam. The surface soil, if it contains much vegetable matter, should be scraped off a strip three to four feet wide and as long as the dam, and the depression filled with earth-clay is best-that contains little or no organic matter. If the bottom of the dam where it meets the normal earth is constructed with sods, or other material which will decay, in time the water will find its way through the porous earth.

The pools of the South, to which reference has been made, sometimes have an extreme depth of 12 to 15 feet, and may cover a fraction of an acre or several acres. I have known one 
of these pools to furnish water for a hundred head of cattle during a long continued drought. It is difficult to explain why more pools, lakes and fish ponds are not constructed. Possibly the reasons are that there is a prejudice against them, and well there may be, since they are usually so shallow that the water becomes impure, and since it is not generally realized that a substantial dam can be erected by the use of earth alone. If it is thought advisable not to allow the animals to go to the pool, it may be fenced, since it is not expensive to lay a pipe in the dam, when it is being constructed, on a level with the bottom of the pool, the outer end of the pipe being furnished with a ball and cock to regulate the flow of water into the trough.

Usually it is not advisable to build eisterns for storing water for barn use, since they are too expensive if built as large as needed. A cow requires from forty to eighty pounds of water daily in the summer. If sixty pounds be taken as the average, it will be seen that it would require a cistern of three hundred and fifty barrels capacity to supply a herd of fifty animals for one month. In some cases the water of a stream or well may be so highly charged with the products of magnesian limestone as to produce goitre, in which case soft water should be supplied for the horses. 
Streams or springs are often available for summer, but they seldom supply ideal water conditions in winter. Young animals, and especially cows in milk, should not be required to drink water at a low temperature or be forced to travel long distances for it in cold weather. The only really satisfactory method of supplying the domestic animals with water is to bring it into the barn, and if the water in the pipes is not under pressure, a small storage tank may be placed in a mow and surrounded by straw. Such storage tank may be built, if small, out of rough 2-inch plank, spiked together, or, if large, of 2-by 4-inch scantling, spiked flatwise one upon the other; in both cases the tank is lined with galranized iron. All barns provided with steam boilers should also be provided with a few small steam pipes leading to the water boxes, that the drinking water of the animals may be raised in winter to $98^{\circ}$ Fahr.

Animals do not relish lukewarm water in the winter, but they really enjoy hot water. The economy and safety of using hot drinking water will justify the expense of providing it. This is especially true in the winter dairy and when horses have severe winter work. An orerheated, tired horse may drink all the hot water he desires without danger. Water taken into the stomach at $40^{\circ}$ Fahr. must absorb heat enough 
from the system to raise it to about $99^{\circ}$. To do this food must be burned, as literally as coal is burned in the boiler to heat water. It requires more units of heat to raise a pound of water one degree in temperature than any other substance except two or three of the gases.

There are now so many styles of really good air motors or wind mills, that water from wells may be pumped at a minimum cost into storage tanks. There is no longer any excuse for pumping water by hand for any considerable number of animals, nor for compelling them to seek water in cold weather at some distant stream. As has been said, there are many ways of securing a supply of water for the barn. The details of accomplishing the results desired are many, but the result should always be the same: an abundant supply of water within the barn under more or less pressure. If this is not secured the plans of a barn, as a whole, are urisatisfactory. 


\section{CHAPTER XVI}

\section{BCILDING THE BARN-THE BASEMENT}

Squaring the foundation site is a simple operation, yet few are able to perform it, and it is seldom that a surveyor is at hand. Buildings are so generally placed with their fronts parallel to the highway or the private way, that the road may be assumed to be the base line. Four stakes set in the middle of the road, as shown in Fig. 96, establish the base line, from which is measured the distance from the road at which it is desired to place the building. The stakes A and B should be placed farther apart than the width of the front of the building; they are connected by a line which is parallel to the road and forms the permanent base line. Next the stakes $\mathrm{C}$ and $\mathrm{D}$ are placed, and also connected by a line. With a 10 -foot pole, six feet are measured off on either line, beginning at the intersection of the lines, and eight feet on the other line. If the line $C$ to $D$ is at right angles to the line $\mathrm{AB}$, the 10 -foot measure will just reach from 6 to $S$, since 6 multiplied by 6 , plus 8 multiplied by 8 , equals 100 , 
and the square root of 100 is 10 . Should the 10 -foot measure be longer than from 6 to 8 , the stake D is moved to the left until the pole reaches from 6 to 8 ; if the measure is too short to reach from 6 to 8 , the stake is moved to the

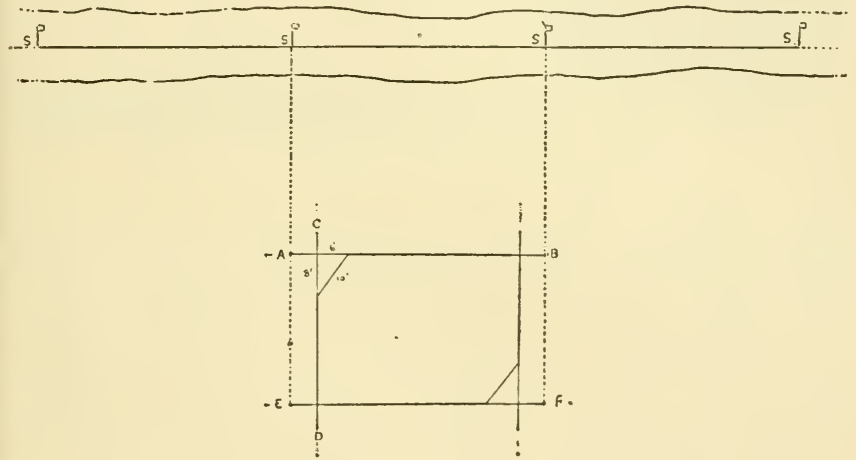

Fig. 96. Locating the barn.

right. All of these measurements should be gone over two or three times, as in moving the stake the lines may stretch or shrink. Either a pin or a pencil mark may be used to indicate the measurements on the lines at 6 and 8 .

If the building is to be 26 feet deep, that distance is measured on the line $\mathrm{CD}$ and the same distance from the line AB. Stakes are then driven and a line drawn from $\mathrm{E}$ to $\mathrm{F}$, and in like manner a line is drawn from $G$ to $H$. The work is verified by squaring the last angle as in the first case. The eight dots represent 
stakes driven in even with the surface of the ground, at just 10 feet from the corners. Since it will be necessary to remove the lines before the horse scraper can be used in excavating, and as the construction stakes at the corners will be disturbed, the short stakes become necessary that the lines may be restored as the work proceeds and the excarction kept square and true. It will be seen that a line drawn from A to B will restore the base line, and in like manner the other lines may be quickly reproduced. It will be necessary, too, to restore these lines before the foundation wall is begun. By "plumbing" downward from the restored lines, other lines may be placed in the bottom of the excavation, which will be duplicates of those first drawn.

\section{EXCAVATION}

Barns are now usually built with a basement story. This implies that the building is to be placed on more or less sloping ground, in which case the removal of some earth will be necessary. The basement story should extend well above ground, to economize construction and to secure dry walls and floors. It is a great mistake to place animals in cellars. The dotted line in Fig. 97 shows an incline rather too 
steep; and in Fig. 98 one that is not steep enough. It is better to place the barn where wanted, even if the incline has to be changed,

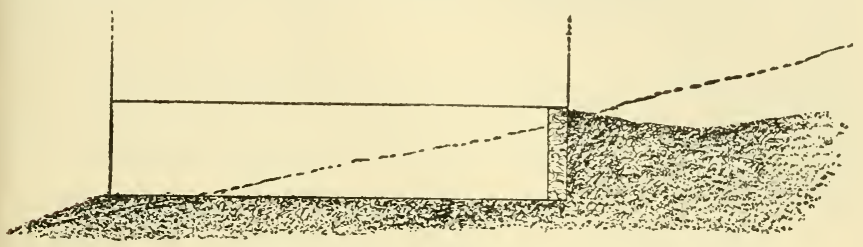

Fig. 97. The original incline or slope is too steep.

than to place it in an unhandy position that the best slope may be secured. It is not diffcult to construct a basement barn on level or nearly level land. In the latter case, all of the basement walls may be of wood, since provision can be made for a driveway to the second floor by means of a retaining wall built some ten or

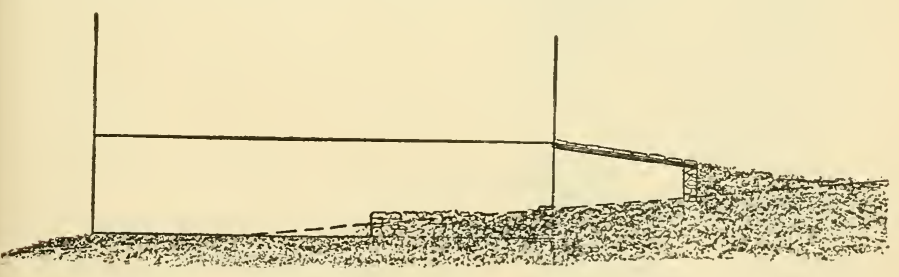

Fig. 98. The original slope is not steep enough.

twelve feet from the barn; the space between the wall and the barn may be bridged (Fig. 99). Cast-off steel or iron rails form durable and excellent sleepers for such a bridge, the 
plank being kept in place by spiking two-inch pieces, one on either end on top of the bridge

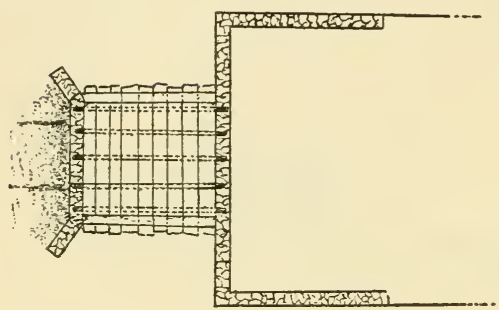

Fig. 99. Bridge into the barn. plank. In case no retaining wall is built, and the earth lies immediately against the basement wall(Fig.100), dampness may be largely prevented from reaching the stable and the animals by building a second wall across the side or end of the barn, inclosing a space or room for roots immediately under the drive-

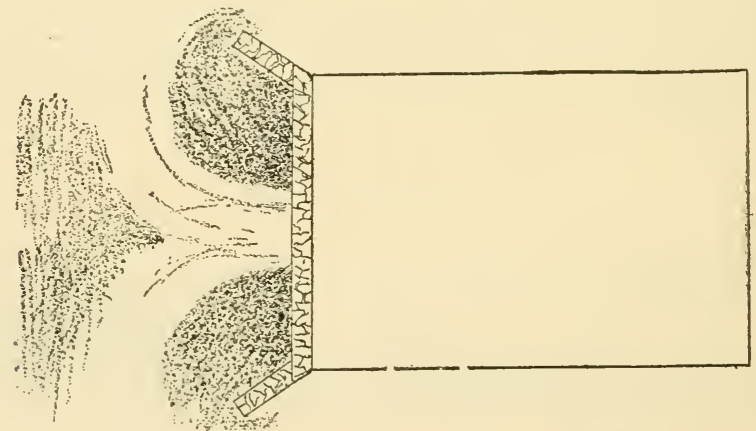

Fig. 100. An embankment entrance, with retaining walls holding the cormers.

way. The floor over this root-cellar should be deafened to prevent frost entering from above (Fig. 101). The second wall will remain com- 
paratively dry, since no damp earth rests against it. This location of the root-cellar makes it convenient for unloading the roots through trap doors in the floor, which are kept partly open
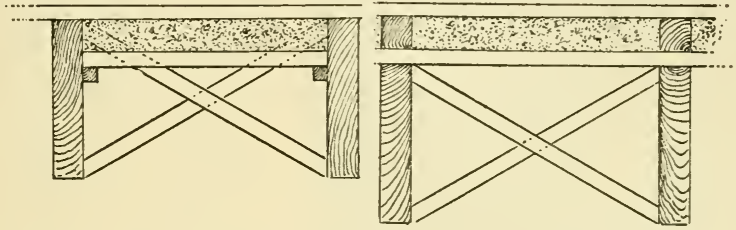

Fig. 101. Deafening or packing the floor, to keep out cold.

for a time after the roots have been put in, to prevent them from heating.

\section{WALLS}

The foundation walls for barns need not necessarily extend below frost, if the earth is as dry as it should be; for a slight settling of the building does not result in injury, as in the plastered house. All that is necessary is to make the walls broad and strong and to have them well drained.

Masons understand the necessity of bonding stone walls, and know how to perform the work; but too often they are careless, and therefore need to be supervised. In Fig. 102, a well bonded wall is shown at the left end, and one imperfectly bonded at the other. If the wall 
should chance to pull endwise a crack would appear to the right of the dotted line, since in the seven layers shown there is but one stone,

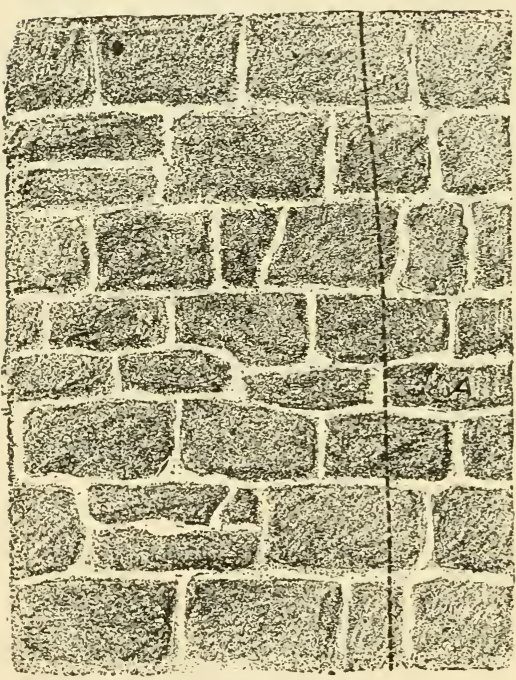

Fig. 102.

Good and faulty construction in a wall.

A, that has sufficient contact to bond the two stones upon which it rests. The wall should also have its face and back side tied together or bonded, or it may split apart near the middle. Two walls, one of which is properly bonded, the other is not, are shown in Fig. 103. One layer only of stone can be shown in the diagram, but it will readily be seen that if the course which is placed on the one shown is laid like it,- that is, if the faulty bonding near the back side be continued for several courses - the wall will pull apart. The small, narrow stones have been placed at the back side of the wall, and the good stones in the front of the wall; this is all very well, but some long stones should reach from the 
back side of the wall to near the face, if the bond is made good. No stone should reach entirely through the wall, since in cold weather the frost will follow through such stones from face to rear.

There is no economy in using mortar which is poorly mixed or that which contains too much sand and too little lime or cement. If the lime or cement, that is, the binding material, does not come into immediate contact with every particle of sand, then the mortar will be weak. If not enough of the cement or lime is used, the bond will also be weak. For stone walls not more than four parts of sand to one of cement or lime should be used. If the sand be sharp and clean a much stronger mortar is secured than when it is
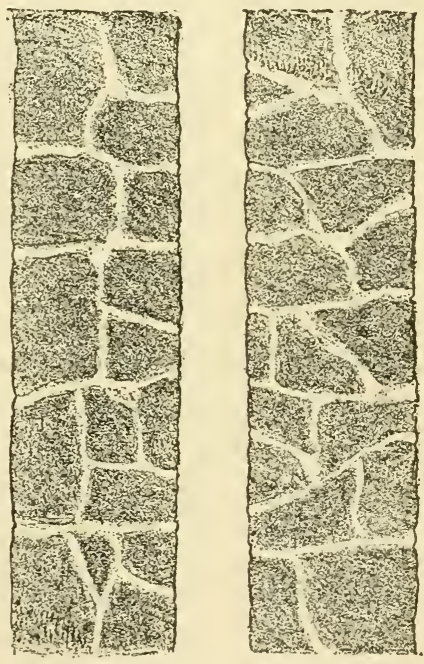

Fig. 103.

Poorly and properly bonded. composed in part of rotten sand mixed with vegetable matter. If the materials are good and they are mixed in the right proportion, still good mortar will not be secured unless they be thoroughly 
mixed. The best masons use the least mortar, while poor masons are wasteful of it.

The prices given below are not applicable to the whole United States, but they may serve to decide the relative proportions of sand and lime which should be used, and the kind of lime which can be used most economically. Water lime retails at about eighty cents per barrel, and three parts of sand and one of lime, if the latter is fresh, should make a strong mortar. Water lime deteriorates rapidly with age, while the higher priced cements deteriorate quite slowly. Stone lime should be fresh and in no case air-slaked. It costs about one dollar a barrel and may be mixed three of sand to one of lime. Rosedale cement costs about $\$ 1.25$ per barrel, and may be mixed four to one. Portland cement costs about $\$ 3$ per barrel, and if used instead of the cheaper materials named above, may be mixed five to one. It should always be used for pointing walls and in the construction of cemented floors, in which case it should be mixed two or three to one. All this presupposes that the mortar is so thoroughly mixed that a lime film will surround every particle of sand.

The cement and water lime is mixed with the sand before it is wet, and this dry mixing should be most thorough, as the strength of the 
mortar is largely dependent on the uniform incorporation of the cement with the sand. This mixing can be much more perfectly done when the material is dry than after it is wet. Other precautions are necessary. The mortar should contain the minimum of water which will permit it to work freely, and when the mortar is used it should be solidified, that is, pushed together by means of a trowel or by the material which is laid upon it. In case of cement or grout floors, the material should be pounded thoroughly. The object of all this is to compel each particle of sand to firmly touch other particles. The tendency to "water-log" mortar, to save labor in spreading it, is too common.

If, from any cause, the basement walls must be largely of stone, the tendency for them to gather moisture may be somewhat overcome by plastering them with cement mortar, or studding may be placed against the walls upon which unmatched boards may be nailed (Fig. 104). The warm air of the stable cannot then reach the relatively cold walls, and little condensation will appear on the boards, since they are always more nearly the temperature of the stable than are the stone.

Wooden basement walls are preferable in all ways to those constructed of stone, grout or 
brick, wherever the earth does not rest against them. An excellent method of constructing the walls of the basement story is shown in a section of the first story, Fig. 10t. The studding should be $2 \times 6$ inches, with short pieces of $2 \times 4$ placed edgewise between them to serve as outside nailing girts.

A broad, steep water-table is placed just above the upper end of the studding to receive

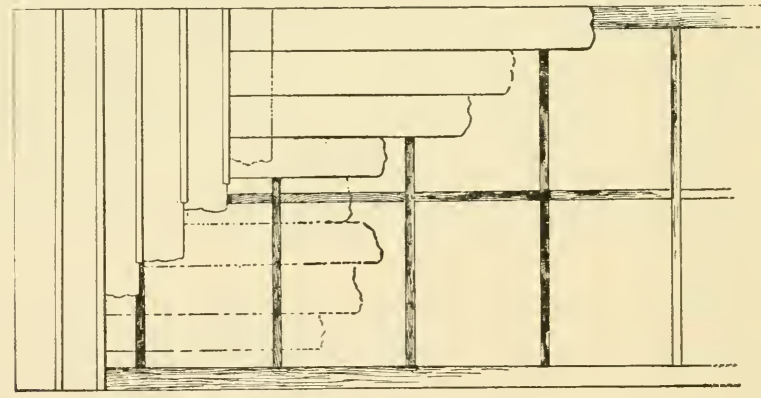

Fig. 104. Lining the basement wall.

the boarding above the basement and to improve the outside appearance of the building. After the outside boarding of the basement and the window frames are placed, the inside of the wall is boarded horizontally with unmatched seasoned lumber, and as the boards are being put on, the hollow wall space is filled with short straw or straw and chaff. This construction has proved to be the most satisfactory of any tried. The 
wall is cheap, durable, dry, excludes the cold, and still allows a little fresh air to enter the stables gradually. Objection has been made to this construction on the ground that it harbors mice and rats. After having used buildings with walls of this character for a quarter of a century, I must say that the objection is not well taken.

\section{FLOORS}

The floor of the first story should be partly of wood and partly of cement or of brick.

All voidings of the animals should be removed from the stable at least once a day. Allowing the manure to drop through gratings, with the view of letting it remain there more than one day, is decidedly wrong, and any arrangement which does not admit of the thorough cleaning and airing of the stable daily is objectionable. Nor is the practice of washing out the stables economical, since it necessitates great waste of manure or too great expense in caring for and removing the diluted excreta. If the floors and stable be well cleaned with shovel and broom, and dusted with gypsum, dry earth, sawdust, or chaffy material, good sanitary conditions will be secured easily and cheaply. While the stables are being cleaned and treated they should 

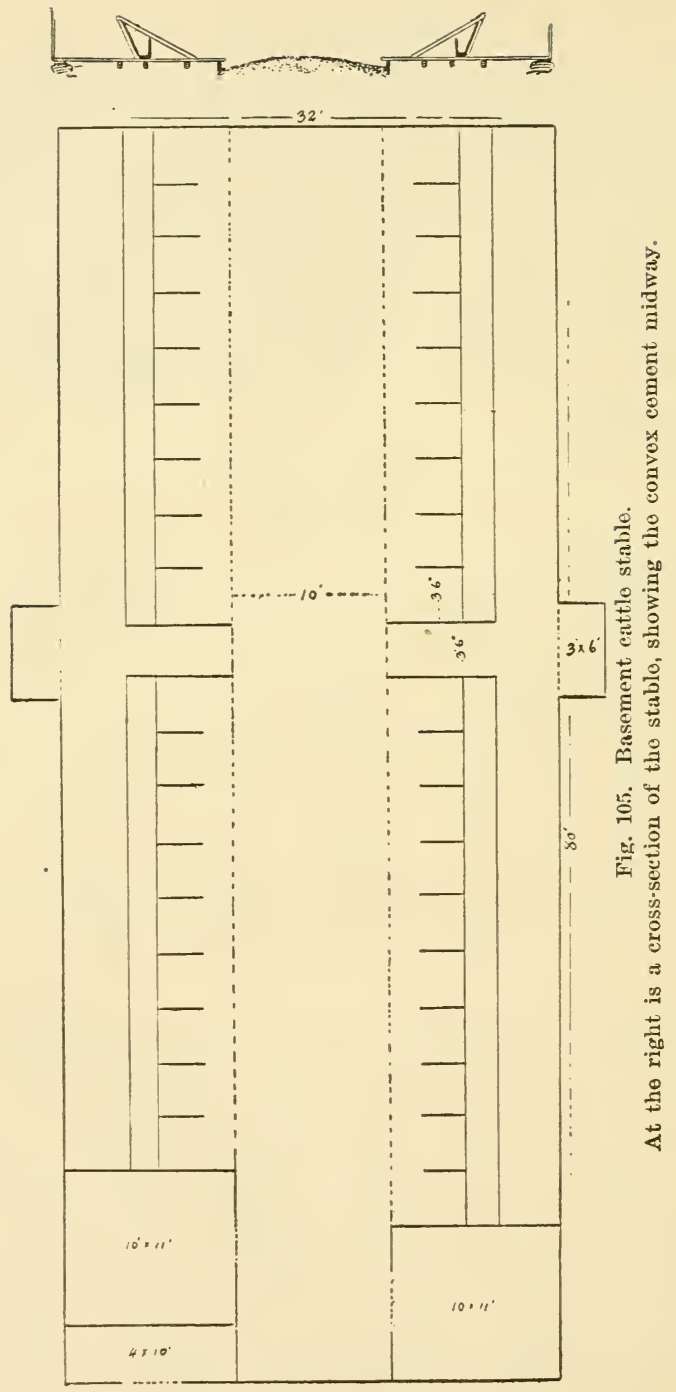
also be aired. The animals meantime should be allowed to stretch their limbs, by which it is not meant that they should be hooking one another around a muddy barnyard, or running foot races up and down the lane. On the one hand, it may be all well enough for those who sell animals at fabulous prices and have long bank accounts, to procure water-proof blankets for them, and to accompany them on their regular daily "constitutional." The other extreme is where the animals are fastened by the head or neck by contrivances not always comfortable, and left standing for six months without being removed from their stall. Is there not a happy medium between these two extremes?

Animals are more comfortable on a wooden floor than on one built of either brick, cement, or asphalt. Notwithstanding this, most of the floor of the basement should be constructed of more durable material than wood. If the animals are kept fully bedded, as they usually are not, then it would be best to discard mooden floors entirely. Fig. 105 shows a basement floor designed for cattle. The part where the animals stand is of wood, the balance of hard or pavement brick set edgewise on a bed of sand. The cement or grout floor may be substituted for the brick if desired. If the cracks between the bricks in the floor are filled with thin 
cement mortar, the floor becomes water-tight, though this is not necessary except in the gutters. The ground underneath the wooden floor should be leveled and pounded, and covered with a thin layer of salt to preserve the wood. The plank which forms the side of the drip should be of oak or some other durable wood. The $2 \times 4$ pieces to which the floor is nailed when first iuilt, need not be replaced when they rot, since the dirt underneath will be smooth and hard. The large nails which fasten the floor to the oak piece at the rear and the mangers combined will suffice to keep the floor plank in place; the only object in placing the nailing pieces at first is to facilitate construction. The plank of the floor should be of some uniform standard width, as 8, 10, or 12 inches wide, that repairs may be made quickly when the floor gives way.

\section{STALLS}

When a dairy of some size is kept, the cows may be arranged in double rows. Fifty cows could be crowded into a barn $80 \times 32$ feet. But fifty cows of 800 pounds each weigh 40,000 pounds; and if the stable is ten feet from the top of the lower floor to the bottom of the upper floor, it rould contain only 25,600 cubic 
feet of air space. This is manifestly too little, as 1 cubic foot of air space should be allowed for each pound of live animal. Many stables, in fact most stables, provide but one-half of a cubic foot of air space for each pound of live animal kept in them; in such case it is impossible to keep the air approximately pure or the stable decently sweet. To realize what this means, suppose a bedchamber be constructed for a man weighing 160 pounds. If one foot of air space be provided for each pound of live weight, the chamber might be built 4 feet wide, 7 feet long and 6 feet high. This would give 168 cubic feet of air space. If the bedchamber be made proportionally as large as are most cow stables, its dimensions would be 3 feet wide, $6 \frac{1}{2}$ feet long and $4 \frac{1}{2}$ feet high. To insure good air in such a sleeping room one side of it would have to be knocked out. If one or two box-stalls and one feed-bin are provided in an $80 \times 32$-foot barn, with 12 -foot ceilings (Fig. 105), and room for a hallway, 3 feet wide, be left at one end of the building, it will then accommodate thirty-nine animals. Each one would have 800 cubic feet of air space, the required amount. The first story of most cow stables is about seven feet. It is seen how easily the stable may be overcrowded. A high story gives opportunity for long windows 
and for placing them well up from the floor, and for good ventilation. If the ceiling is to be reduced in height, which it well may be, the building should be proportionately longer.

A section of a part of the inside of the wall with swing windows is shown in Fig. 106. The windows should be of one sash and hung near the middle, as shown, by means of a piece of iron $3 / 8$ of an inch in diameter and 4 inches long. A hole for the reception of the iron, and of the same size, is made through the window sash and extends into the jambs of the frame about one inch. A button on the side of the jamb is used to hold the window partly open when required. This allows cool air to pass in at the bottom and the warm, vitiated air to pass out at the top in small, broken streams. It will be noticed that in case of a storm no rain or strong current of air can reach the stable. Usually too few and too small windows are provided, through which the manure from the stables is not unfrequently thrown.

Some additional ventilators should be provided; these may consist of wooden tubes extending from the ceiling through the roof, so constructed that the foul air may enter them. They need not be numerous or large, as the windows when slightly open form excellent ventilators. Two things should be kept 
prominently in view in ventilation: first, no strong draughts of air, or, as a distinguished professor puts it, "great gobs of raw air," should be introduced; second, ventilators should ventilate both at the ceiling and the floor, as in these two places will be found the most impure air. Ample air space is most economically secured by high ceilings, rather than by horizontal enlargement. The air can be kept reasonably pure by the introduction, at several points near the lower floor, of small volumes of slowly moving fresh air.

Two stairs should lead from the basement to the second floor in all large barns to economize time; the openings in the upper floor had best be provided with flap doors, Fig. 106. A swing window for stable. which can be left open in muggy, warm weather to assist ventilation, or closed in cold weather to economize warmth.

Many varieties of stanchion for confining cat- 
tle in stalls are in use, some really good, but mostly defective in one or more respects. It would take too much space to describe all of the various contrirances and to illustrate them and to call attention to their good and objectionable points. Some confine the animals too closely, others give too much freedom and allow them to become soiled; some are too expensive, and some are not durable. I shall describe but one kind of fastening and manger which, after trying numerous patent arrangements, has been found to be excellent. It is quite possible that there are better ones. The one thing which has been learned about stanchions by experimentation and observation is that they may be so complicated and handy as to be unhandy. The size and character of the "drip," the comfort and cleanliness of the animals, the ease of fastening and unfastening, the noise or quiet of the stable, and the effect on the animals, should all be considered. While using one stanchion, the animals became wild and made frantic efforts to pull their heads out when the attendant approached to unfasten them. As soon as another fastening was introduced they became docile. With one stanchion they would lie down more frequently than with another. With one kind of manger the animals are tempted to hook one another, and in reaching 
for food would fall upon their knees and injure themselves. Most of the contrivances were not easily adjustable, so that when the size, or rather length, of the animals varied the standing room was either too short or too long. Some had posts to sustain the stanchions; these intercepted the light and prevented an unobstructed survey of the animal. They gave the stables a forbidding, dark, prison-like appearance.

The individual stalls should be, for smallish animals, 3 feet 6 inches from center to center, and 3 feet 8 inches for larger animals. The partitions between the animals need extend only far enough backward and upward to prevent them from reaching each other with their horns. When dishorning is practiced the partitions may be lower than when it is not.

\section{MANGERS AND TIES}

The cross section of a floor and the skeleton of a bracket upon which the mangers are built are shown in Fig. 107. The mangers of cattle stables should be easily movable. This can be accomplished in the following way: Construct one more bracket than the number of stalls required in the line of mangers. Place one of the brackets at the end and one intermediate between every pair of stalls; fasten 
them lightly to the floor with nails, which should be removed when the mangers are completed. Fig. 107 also shows the cross section

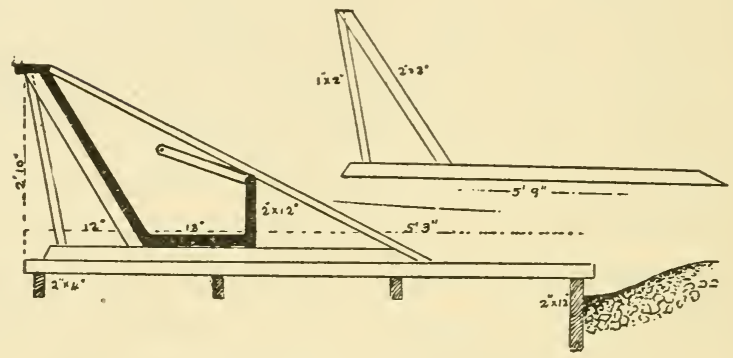

Fig. 107. The building of a manger.

of the brackets, with bottom, front, and back side of the manger placed.

The Newton cattle tie (Fig. 108), though rather expensive, has proved most satisfactory. It is made of one piece of round, durable wood, as ash, about $1 \frac{1}{4}$ inches in diameter and bent at the corners, and is furnished with a

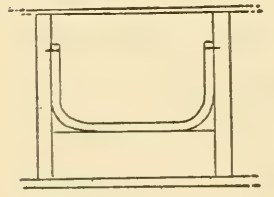

Fig. 108.

Newton cattle tie. flat ring which encircles the bow at the middle, to which is attached a swivel; to this is fastened a rope to encircle the animal's neck, the rope being furnished with suitable fastenings at the ends. The bows are attached to the divisions on a level or a little above the animal's throat when standing; 
when lying down the bow rests on top of the manger, which is about $1 \frac{1}{2}$ feet lower than the ends of the bow. It will be seen that since the bow describes an are of a circle in passing downward, it tends to pull the animal towards the manger when it lies down, and hence away from the soiled drip.

In midsummer window curtains, drawn during milking time, serve to quiet the flies and the cows, as does also a light spraying of the animals with kerosene before they are turned out in the morning. A blanket tacked over the entrance door to the cow stable will brush most of the flies off the cattle as they enter. 


\section{CHAPTER XVII}

BUILDING THE BARN-THE SUPERSTRUCTURE

THE kind of superstructure best to be adopted for the barn depends on many conditions. The balloon construction may be used for small barns, but large ones naturally require large timbers or many small ones, hence the old style of frame-work, with some modification, is usually adopted. In modern barn buildings the main timbers are reduced in size, more and lighter braces are used in lieu of the large mortised and pinned braces. They are cut with smooth, angled ends and spiked to posts and beams. A brace of $2 \times 4$ inches is inexpensive, and allows of following the old rule of placing a brace in every angle made by the principal timbers.

Another modification should be adopted: the joists, so far as possible, should rest on sills and beams and not be gained into them. It is unwise and unscientific to cut gains for the reception of the ends of the joists at considerable expense, since such gains weaken both joists and sills. In most cases the joists may 
be placed on top of the sills, thereby obviating the necessity of framing, while preserving the strength of sill and joist entire. When it is desirable, as it often is in small structures, to have the top of the sill or beam coincide with the tops of the joists, it is cheaper and better to use a rather light timber and fortify it by nailing upon it $2 \times 4$-inch studding (Fig.

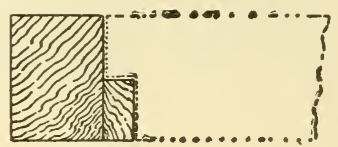

Fig. 109. Laying the joist.

109), thereby avoiding the necessity of cutting gains, while giving additional strength to the timber which supports the joists.

The joists in barns should be bridged as in houses. That part of the barn floor which is above the root-cellar should be deafened, as shown in Fig. 101. Cleats nailed on the sides of the joists serve to support the short boards which carry the deafening material. The 2-inch space between the false and the true floor is filled with mortar composed of about five or six parts of sand to one of lime or cement. If all of the floor driven upori above the basement is deafened, it will deaden sound and promote warmth in the lower story.

While the balloon frame has been almost universally adopted in the construction of houses, it is only recently that large barn frames have been successfully constructed on the same gen- 
eral principles. The plank frame has now been so modified and improved that it serves well for the largest farm building. All of the frame timbers are sawed two inches thick and of variable widths, as required. Instead of uniting the timbers by means of mortise and tenon, they are fastened with wire spikes. This new

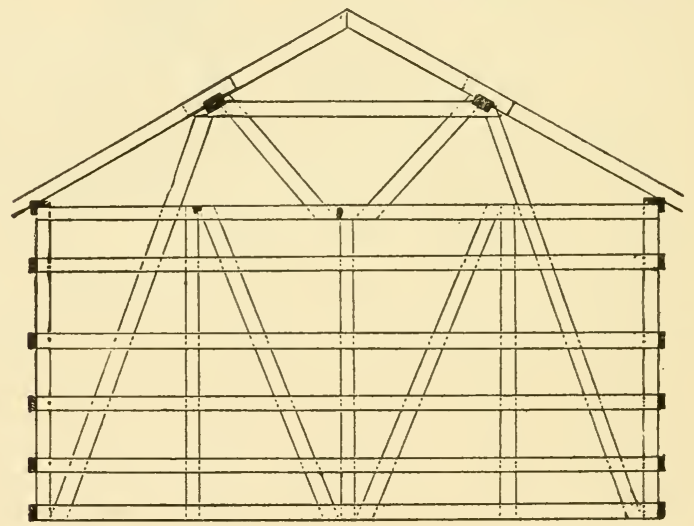

Fig. 110. Barn frame.

method secures as strong a frame as the old, and saves from 30 to 40 per cent of material, while the plank frame is more easily and cheaply erected than the large timbered frame is. The 2-inch frame material can be so placed as to direction and position that it will secure the maximmm of strength with the minimum of lumber. 
The illustration (Fig. 110) shows one end of a $67 \times 97$-ft. barn, posts $18 \mathrm{ft}$. long, recently erected at the Pennsylvania Agricultural College. A cross-section at one side of the driving floor is also shown (Fig. 111). A cross-section of a built-up post is seen in Fig. 112. It will be seen that the building is firmly tied together,

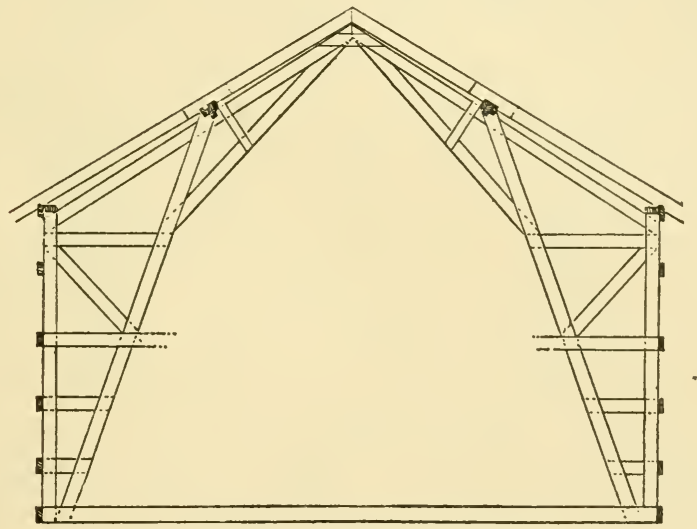

Fig. 111. Cross-section of the frame.

the roof fully supported, and that no timbers obstruct the unloading of provender by horse power. This new method of constructing large frames is so little known and the principles involved are so valuable that I append a foot note at the risk of being misunderstood.* Since long, large timbers have become expensive,

*Shawrer Bros., Bellefontaine, Ohio, furnish models and bills of material for plank barns at a low cost. 
it is probable that the plank frame will become as common in the near future, in barn building, as the balloon frame is in house building.

It is frequently convenient to place

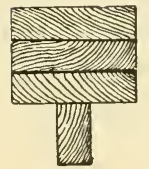
horses or other animals on the second floor above other animals, or above a covered yard, in which case a tight

Fig. 112. floor may be made as follows (Fig. Built-up post. 113): Lay an unmatched, rough inch floor; upon this place strong, tarred buildingpaper, with joints well lapped. Saw and prepare the 2 -inch planks which are to form the floors. For every four hundred square feet of floor, procure one barrel of hard Trinidad asphalt and three gallons of gas tar. A large iron kettle may be used for heating and mixing the material, which should be in the proportion of about one to ten. With an ax remove the barrel, and chop off and place in the kettle pieces of asphalt until it is not much more than one-half full, then add the due proportion of gas tar. The kettle should be placed in a rude arch and at a little distance from the building. By means of a slow fire heat the material. When all is ready, dip the hot mixture into a galvanized iron pail and pour it in a small stream on the paper, spreading to the width of the plank intended to be laid, by means of a shingle or paddle. Lay the 
plank in the hot material, being careful that when it is spiked down the hot asphalt does not fly up into the face. Then proceed to lay other planks in like manner. Finally pour some of the material into the cracks if there should be any.*

Should the floor become worn in time and need repairing, even up the surface by spread-

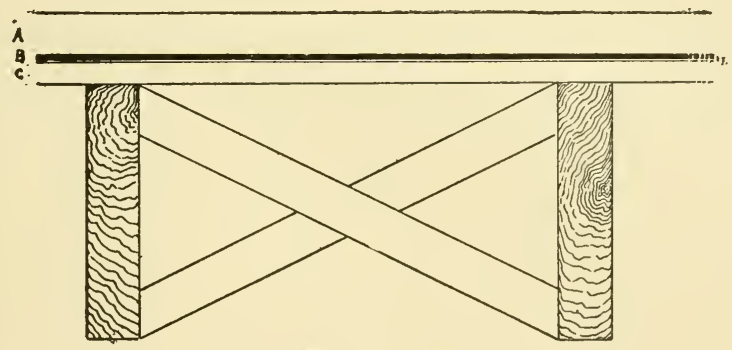

Fig. 113. Making a barn floor.

ing thin cement mortar upon it, and upon this lay a second plank floor. The cement mortar will assist in making the floor water-tight and in preventing dry rot. Barn floors which have become much worn from driving over them may be treated in like manner. Where it seems advisable to place cows on the second floor, and over a manure cellar, the following plan may be adopted: A tight floor, as in the former case, is built with drips as shown; a small hole is

*A floor laid, as described, seventeen years ago, is still in good repair. 
placed between each pair of stalls, through which the voidings of the animals may be dropped into the story below, the floor of which is concreted. The objection might be raised that the manure underneath the animals would be objectionable; but since the floor of the stable described is tight when the openings in the drip are closed, and the story below is well lighted and ventilated, the objection does not hold good.

As far as possible, horses should stand with their heads away from the windows, as draughts of air and glaring sunlight are trying to their eyes. A few box stalls are convenient, and assist in providing the two cubic feet of air space which should be allowed for each pound of live weight in the horse barn. The stable should be so situated that the fumes of ammonia arising from it cannot reach the harness and carriages, if they are highly polished and expensive. The horse stable may often be placed on the second floor of the wing, as it brings it on a level with the main driving floor and near to where the wagons are likely to be kept. The story beneath the horses makes an acceptable covered yard. An office, which may be warmed, and a repair room should be provided in one corner of the barn or in a small detached building near to it.

If the farm is ample, and large amounts of 
hay and grain are to be stored, instead of building a wagon house, the main barn might be extended twenty feet, more or less, in length. This additional room may be used for carriages and light harness in part, and in part for the storage of grain, meal, and the like. The space underneath this room would serve to enlarge the cow stable. The place for washing carriages might also be located on the lower floor, where it would serve for storing the milk wagon as woll, and the space above it could be devoted to storing hay and the like. Barn windows should have small panes of glass, as the cross bars of the windows serve not only to hold the glass but as fenders also. Since the glass in barn windows is likely to be broken, the cost of repairs is reduced to a minimum if the panes are small. A cupola, if it is large and well proportioned, may add beauty to the barn and serve to ventilate the mows, thereby making them cooler for the workmen than they otherwise would be. It may also give opportunity for lighting the mows and the floors, thereby avoiding the necessity of windows at the side of the mows, where they are likely to be broken and where they are covered as soon as the barn is partly filled.

Hay and grain contain 20 to 25 per cent of moisture when stored, and hence tend to become warm. The hot, moist air, due to 
this heating, ascends to the roof or cupola and forms an easier passage to the earth for electrical discharges than the normal air of the building does. Thunder storms prevail largely about the time barns are filled, hence they should be provided with good lightning rods, that an easier and safer way may be provided for the discharges than by the ascending warm, moist air of the building. (See lightning rods, Chap. XX.)

Barus not more than sixty feet wide may be covered by self-supporting roofs. The curb or gambrel form is the best. If the gables are clipped, the cost will not be materially increased, while the structure will be much improved in looks. Barns should have strong, wide, projecting roofs; a few extra rows of shingles at the eaves will serve to protect the outside covering and the framework, and will improve the looks of the structure. "Should it be decided to paint the barn, an ample projection will greatly reduce the expense of keeping the paint presentable. Financially speaking, it does not pay to paint the barn unless the boarding is placed. horizontally. The boarding of many unpainted barns is still in a good state of preservation, although they were built more than threefourths of a century ago, and had roofs projecting but a few inches over sides and ends. Pro- 
tected by a roof projection of one to two feet, rough, vertical barn boards may last for one to two hundred years without paint. It may be said, then, that properly constructed barns are painted to improve their looks and not to preserve them. When the barns are well removed from the house and virtually hidden by trees, they may be left unpainted, but where they are conspicuous they should be painted, that the barn may not mar the beauty of the home. The oxide of iron, which usually has a red or reddish tinge, mixed with pure oil, forms a most desirable and satisfactory barn paint. (See Painting the House, Chap. IX.) 


\section{CHAPTER XVIII \\ REMODELING OLD BARNS}

IT Is more difficult to remodel old barns than to build new ones. If the attempt be made to unite several of the detached buildings with the view of making them into one sym-

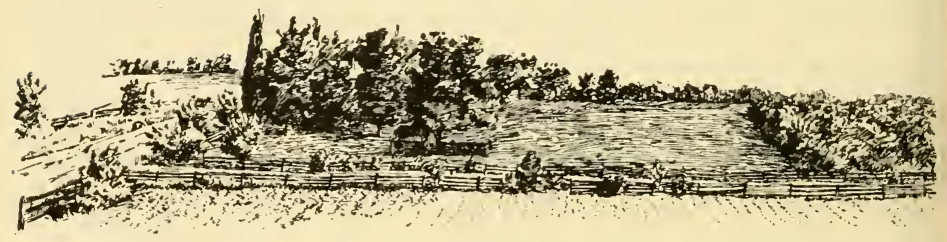

Fig. 114. The scattered buildings on a farm.

metrical structure, much study will be required. The frames of the old buildings are so strong and durable that they should not be thrown aside as useless until it is certain that to utilize them would be more expensive than to tear them down and erect others of new material. Those massive oak sills and posts and poplar swing-beams have for me a meaning and charm which is lacking in the light plank and balloon frame constructed of knotty, wind-shaken hemlock or some other 
cheap wood. It needs no argument to prove that the numerous detached rural buildings so often seen on the farm should be remodeled; but how? To illustrate, let the buildings shown -in Fig. 114, which is from a photograph, be taken. Move the four largest buildings to some suitable site without taking the frames down, and out of the timbers of the other structures build a basement story. It will take just one-half as much material to board the new structure as the four old ones, plus that required to fill the gaps where the old struc-

The profit of the farm is absorbed in doing the chores.

tures do not join (see plan, Fig. 115). These openings, eight and twelve feet, are all so short that the frames may be made continuous by means of light pieces of material, which will serve for nailing girts: When the old buildings have been united, some of the inside posts may be in inconvenient positions. If so, trusses appropriately placed in the mow story will permit the removal of the obstructing post, as shown in Figs. 116 and 117.

If a steep curb roof, which may be self- 
supporting (Fig. 118), be adopted, the remodeled structure (Fig. 119) will have more than three times the available space that the four old structures had. It is probable that there would be nearly enough dimension stuff in the seven other small structures to construct the basement story.

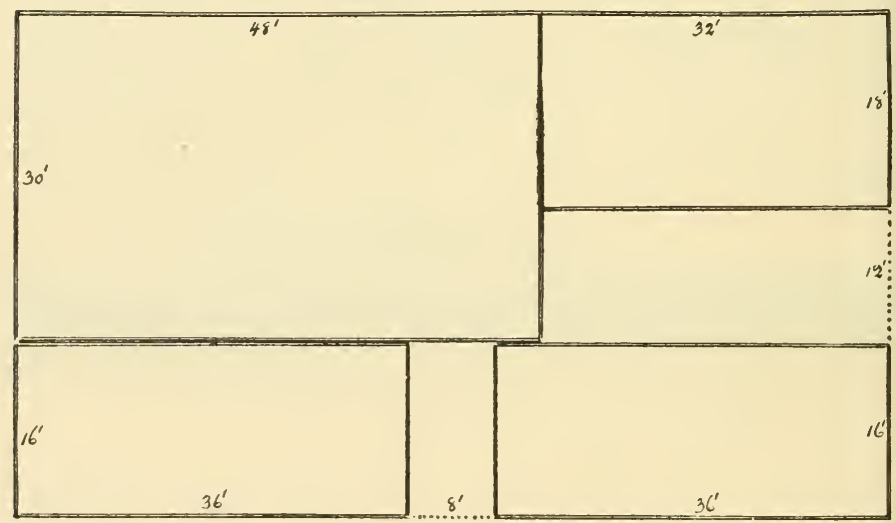

Fig. 115. Plan for condensing the buildings shown in Fig. 114.

But it may chance that no basement story is wanted. If so, the building might be arranged as before, or two more of the small structures might be united to the four larger ones which it was proposed to use in the former case. The barn would then present a rather low appearance; but if the peaks of the curb roof wcre properly treated, that is, clipped (Fig. 120), 
the structure would not be void of beauty. The rebuilt structure, in any case, should be placed on continuous walls, not on stone piers. If the posts of the old structures are of unequal length, the wall which supports those having

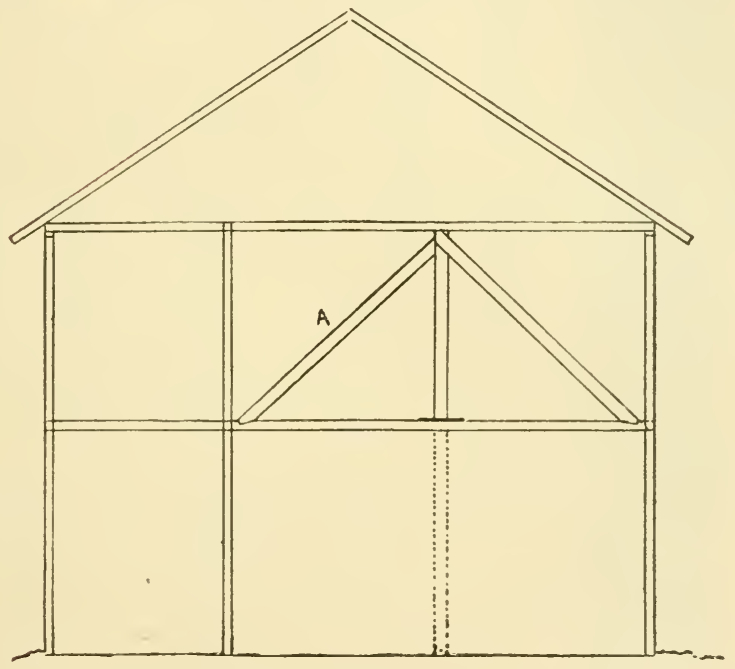

Fig. 116. Trussing where a post is removed.

the shorter posts may be built higher than for those having the longer posts, provided, however, there is not too great a difference in the length of the posts of the several small structures. If there are four or more feet difference, it would then be best to splice the short posts. 
The first story in most of the old barns is entirely too low. This may be remedied by building the outside supporting walls of the proposed remodeled building two to three feet above the level of the ground. This will add as much to the lower story as the wall is above

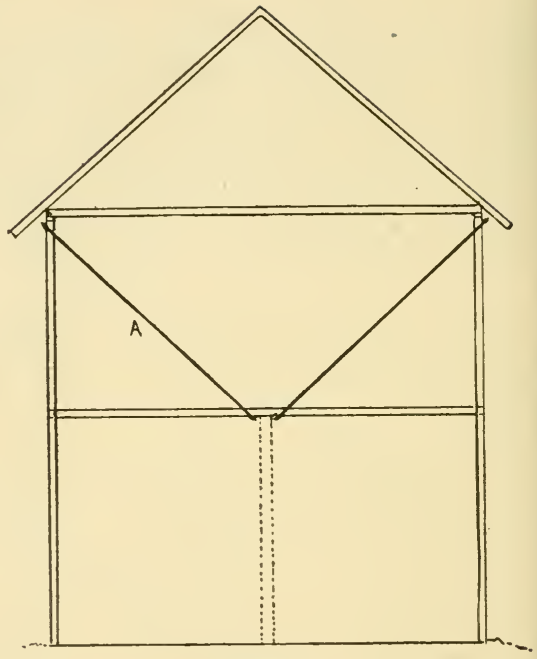

Fig. 117.

A trussed frame, where a post is removed. the ground, less the room required for placing

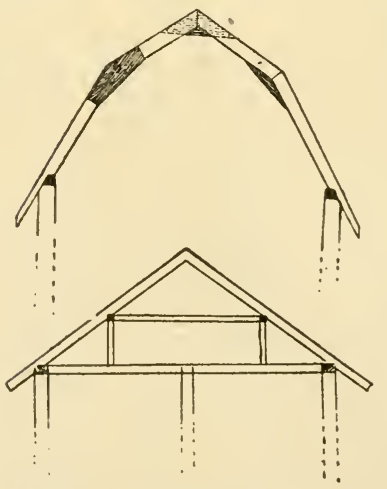

Fig. 118. Old style of roof below, and new style curb roof abcve. the basement floor. If treated in this manner the old inside sills, sleepers, and joists should be removed and the inside post supported on stone or brick piers. All this will give opportunity to construct the basement floors on the ground, or near to it, and of such shape and material as the new plans 
call for. In this case the floor might well be made of grout, since lumber is expensive, and an effort should be made to build permanent and durable structures. If stable floors are placed well up from the ground and have numerous cracks between the planks, they are extremely uncomfortable for the animals. They are, perhaps, the most uncomfortable of all floors, as the air finds access to the stable through the floor, and it is nearly impossible to keep such stables comfortable in cold weather. Such construction of floors is also wasteful of manures, tends to produce "scratches" and other foot and leg diseases in horses, and is unsanitary and altogether undesirable.

Finally, it may be said that when these separate structures are treated in this inexpensive manner without added basement, the available capacity of the building would be double that of the old ones, the time of performing the

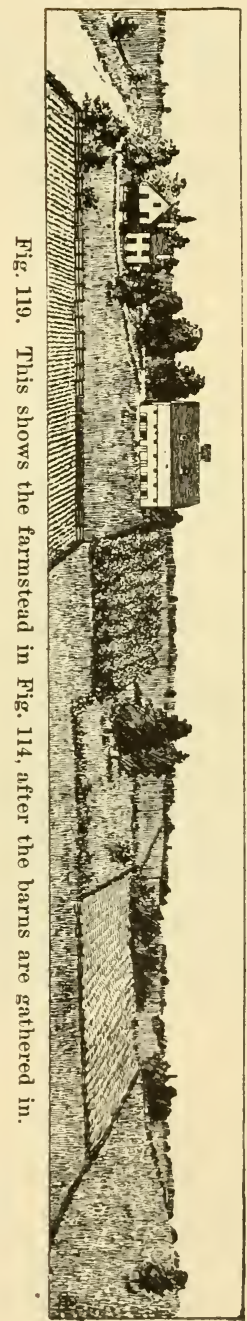


work in the barns would be greatly diminished, and the discomfort of both man and beast would be ameliorated. For the sake of the farm boy and for the animal which he cares for, to say nothing of economy, beauty and neatness, may

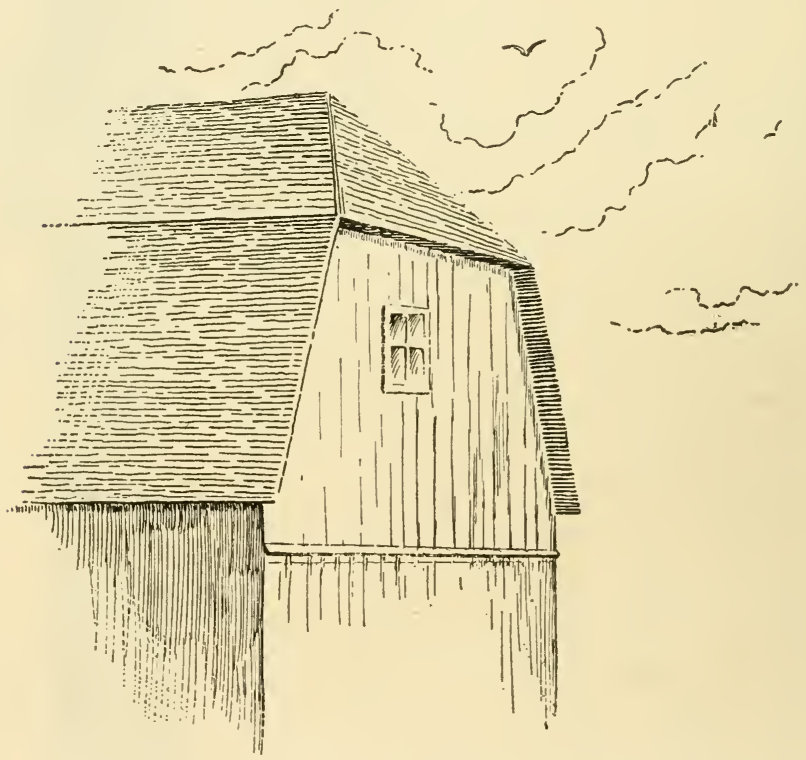

Fig. 120. Treatment of the gable.

I not ask those who have these scattered, unhandy, uncomfortable barns, to study well the illustrations given, which show the old and the new arrangement?

The accompanying illustration (Fig. 121) of 
English farm buildings may be of interest, though this style of barn and the arrangement would not be suitable in America, with its rigorous climate and expensive farm labor.

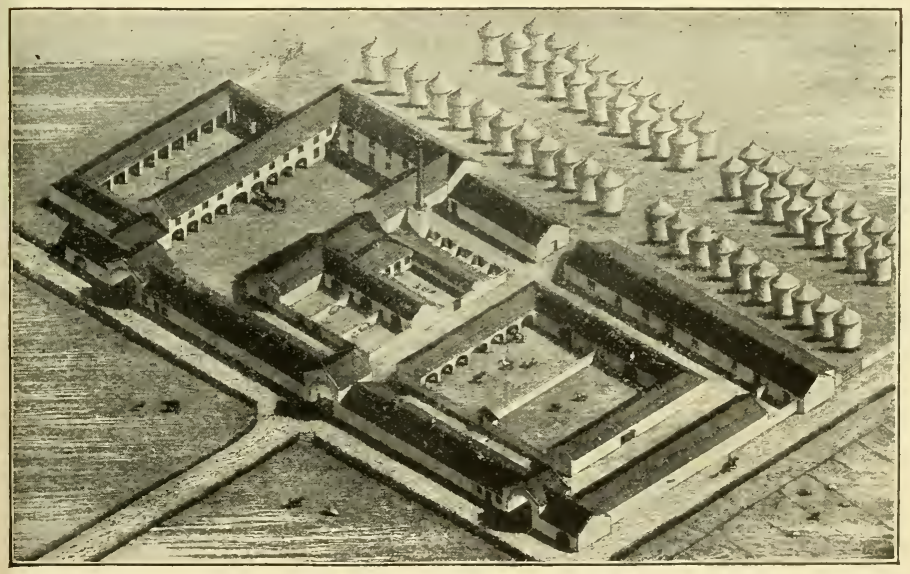

Fig. 121. Knglish farmsteading plan. 


\section{CHAP'TER XIX}

\section{OUTBUILDINGS AND ACCESSORIES}

THERE are various farm buildings which are better when more or less detached from the main barn; and some of these may now be mentioned.

\section{POULTRY HOUSES}

Until recently comparatively few persons have been financially successful in the poultry business when large numbers of fowls were kept in close quarters, as the many abandoned dilapidated yard fences and buildings testify. The reason for such failures was due, usually, to allowing too many fowls to run in one flock. It takes a genius to see and note the conditions of each individual animal once daily in a flock of several hundred birds. Break the flock up into several small ones, each of uniform size and character, and the individual fowl may then be more easily noted. A single diseased bird, if not removed, may serve to inoculate a whole flock with some contagions disease. If the flock contains but twenty to thirty indi- 
viduals, the chance of discovering a drooping bird is greatly increased. This indicates that the poultry house or houses should be easily divided into rather small compartments. Poultry houses usually are about 12 feet wide and not more than 30 to 40 feet long. If more room is wanted than one house furnishes, another structure should be erected some little distance

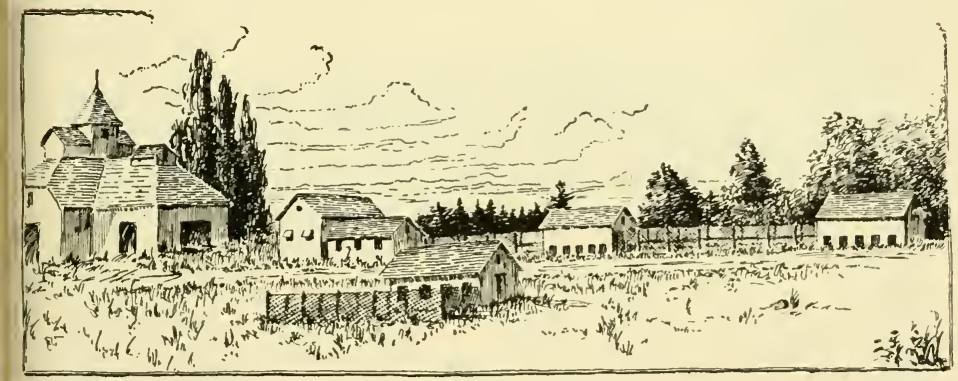

Fig. 122. A poultry establishment sufficient for 150 hens.

from any other one. This will give better opportunity to arrange for large runs or yards than does one long, continuous building. I have yet to see a large poultry establishment furnished with yards as large as they should be, and I have seen but few yards which were properly or fully shaded. The runs should be large and relatively narrow, and set to fruit trees. The plum is best, and may be set the usual distance apart. The trees should be sprayed and cared 
for as in well kept orchards, since the fruit may chance to be more profitable than the poultry. For the health of the fowls and the welfare of the trees, clean culture of the runs should be adopted. In the case of poultry buildings, the distributive method of construction should be adopted rather than the concentrated one. If the undertaking is begun with a well matured plan, these several small structures may not be unsightly when viewed as a whole. An illustration is given of a modest poultry plant large enough for 150 hens and 500 chicks, provided, however, that most of the chicks are sold when from three to six months old (Fig. 122). These structures are built on grout foundation walls to exclude vermin and moisture. The floors are of wood, the sills and plates $2 \times 4$ inches. The boarding is vertical and double,

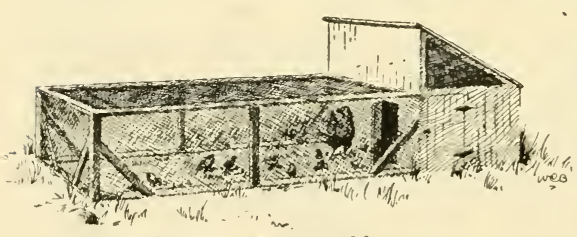

Fig. 123. A moveable coop.

- with paper between t'ie two boardings. The outside boards are planed and battened; the roof boards, which are laid close together, are covered with paper and then shingled. The windows provide for light and, in part, for ventilation. These structures are dry on the inside, and the temperature, though not always above the freezing point in 
cold weather, is comfortable. The building's might be reluced in number or in size, except the brooder house, and yet provide for the same number of birds, if movable coops for the smaller chickens were provided. The illustration (Fig. 1.23) shows a durable, light, movable coop large

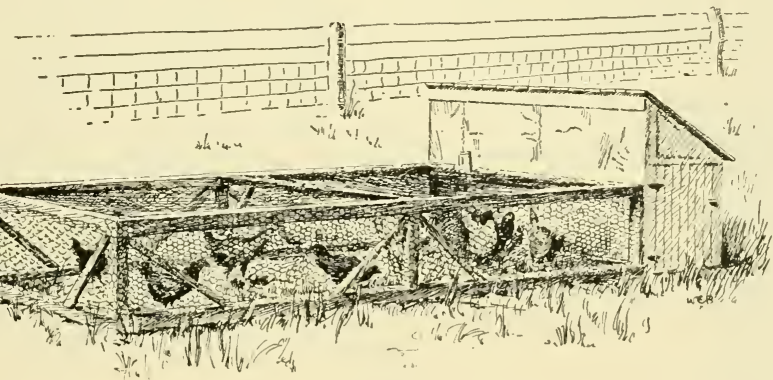

Fig. 124. A large portable coop.

enough for twenty half pound chicks. The coop was designed for use on the lawn. It is inexpensive, and protects the chicks from all their ordinary enemies, both day and night. It weighs but 75 pounds, and can be moved easily by a child by means of a strap attached to one end. When used on the lawn, the coop should be moved and cleaned at least once daily, as fresh pasture for the chicks is thereby provided, injury to the grass prevented, the lawn being benefited by the excrements. The coop shown is $4 \times 8$ feet and 20 inches high, unfloored except the covered 
section, which has a tight floor, and roosts and suitable wooden and sereen doors. A brood of chicks in such a coop would form superior facilities for nature-study work.

When poultry-raising is carried on on a large scale, the movable coops might be built $12 \times 6$ or $16 \times 8$ feet (Fig. 124), the latter the largest size which is easily movable without the aid of

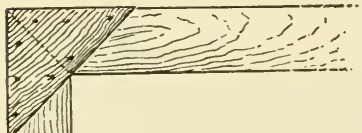

Fig. 125.

Bracing the corners of the frame. a horse. The corners of the sills should be mitered and held together by triangular pieces (Fig. 125). These coops will be found to be entirely satisfactory when used in a pasture or grass paddock near the chicken house. While experimenting with them, it was found that the birds did better when as many as thirty or more chicks were assigned to each large coop than when kept in the large, grassless rums.

The following bill of particulars may be of assistance in the construction of a lawn chickencoop:

Sills $1 \times 4$ inches.

Posts $2 \times 2$ inches, 20 inches long.

Braces $1 \times 1$ inch.

Plates $1 \times 2$ inches.

The covered part of the coop is made of 
$3 / 8$-inch matched and beaded hard pine; the floor of any light wood $1 / 2$-inch or $3 / 4$-inch, matched, but not beaded.

\section{PIGGERIES}

A piggery of any considerable size is the most difficult to plan of all farm structures. One of two methods may be adopted in the East with fairly satisfactory results. If there are woods and some pasture land adjoining or near to the barns, cheap separate pens (Fig. 126), one for each brood animal, may be built near the border of the wood or on the edge of it. There need be little more than a slanting

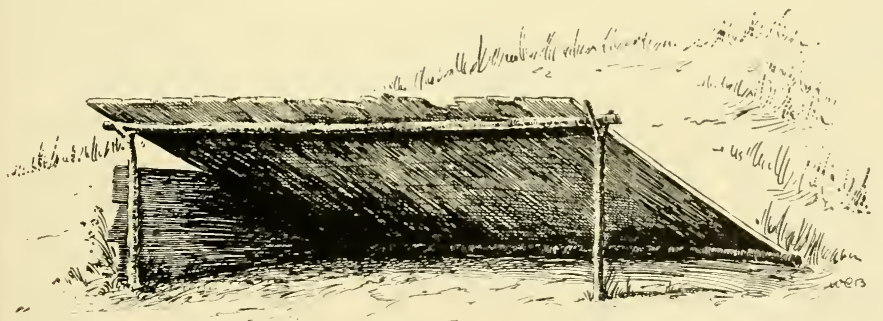

Fig. 126. Temporary shelter for a brood sow.

roof, with the triangular corners at the ends boarded to keep out the wind. The earth forms a most comfortable bed if kept dry and covered thinly with leaves or straw. Of course, these pens are not suitable for brood animals 
farrowing during the winter months. Where but one litter of pigs is raised annually, there is little difficulty; if two litters a year be desired, the first one should be farrowed in April or May, and the other in September or October. In either case these cheap detached pens may be not only satisfactory, but they will serve to fit into a system of pig-raising which may be carried on at the minimum of labor and expense and supplementary foods. By means of a tank or barrel mounted on wheels the animals may be fed, either once or twice daily, in large troughs placed in the pasture. This system presupposes ample areas of grass and woodland, which should furnish not only a healthful run for the animals but much food for them.

Usually the mistake is made of confining pigs in small pens, which may or may not have attached to them small yards or runs. These are always devoid of grass, and offensively dusty and filthy a part of the year, and an impassable mud hole at other times. Whererer circumstances will permit, there should be allotted to each brood animal and her offspring one-fourth acre of land. Two small fields might be provided, one of which would serve for pasture ground for all the animals, while the other would be used for raising crops for soiling 
the pigs or for other purposes. When the lot became fertilized from the droppings of the animals and the grass injured, it should be plowed, cropped and seeded, the animals being pastured meantime in the other field.

Cheap but somewhat more elaborate pens are shown in Fig. 127. These may be built
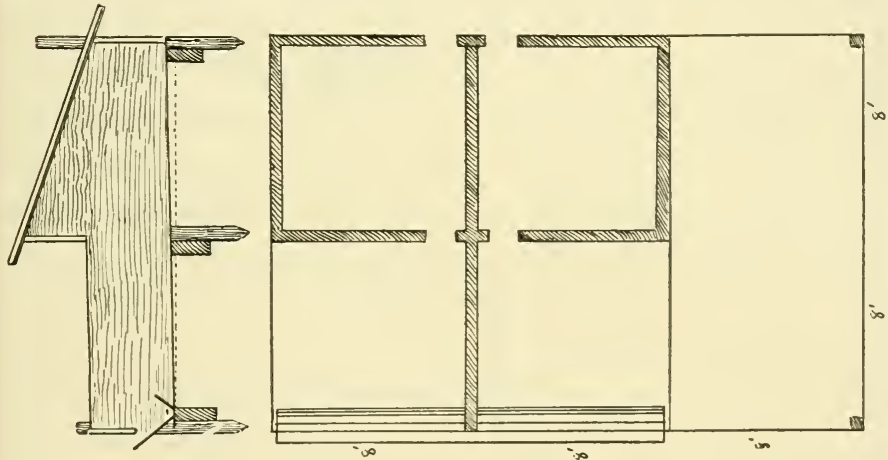

Fig. 127. Pig pens. At the left is shown a vertical section, with the roof over the rear. Yard on the right.

in detached. pairs, or several pens may be placed in juxtaposition. Each pen, including the small outside yard and feeding floor, both unroofed, is $16 \times 16$ feet. The part roofed is $8 \times 8$ feet. After the pigs have attained some size, all doors are opened and the entire herd may be grazed in one field.

A better but more expensive piggery, Figs. 128 and 129, shows five pens, though the plan lends itself to a greater or lesser number. The 
area deroted to each bed is $8 \times 8$ feet. The driveway, which also serves for temporary storage of manures, is 8 feet wide and extends

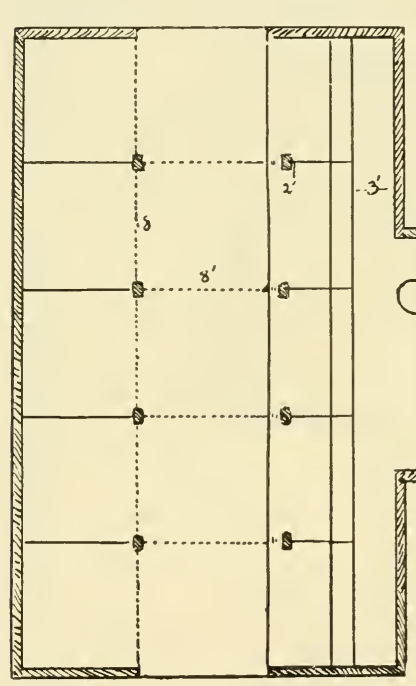
lengthwise through the building. The floor of the driveway should be about one foot lower than the feeding and sleeping floors at the middle, and should be paved or asphalted. (S e e cross section, Fig. 129.) The feeding floor upon which the troughs rest may be 4 or 5 feet long, and Fig. 128. A more elaborate piggery. should descend towards the driving floor. Ordinary gates are hung to the posts which serve, with the boarding, to separate the pens. These gates are fastened at the other end of the posts which separate the feeding compartments. When so fastened each brood animal has a bedroom $8 \times 8$, a receptacle for manure $8 \times 8$, and a feeding floor $4 \times 8$ feet. This arrangement presupposes that most of the foods will be fed in the troughs. If, when the animals are first placed in the pens, the paved 
portion of the floor be soiled with dirt and water, the excreta thereafter will be deposited by the animals on this floor and not in the bedroom. The pig is really a cleanly animal if it is given a few timely sensible hints. When it is desired to remove the manure the gates are all swung to the right or left, as most convenient, and they then serve to fasten all of the animals in the bed compartments, and the driveway is left unobstructed. One of the outside openings to the driveway should also be provided with a gate to swing in, as well as an ordinary door to swing out. These pens may all be thrown open

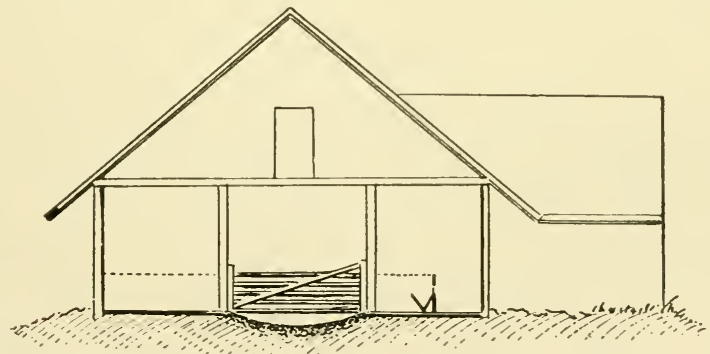

Fig. 129. Elevation of the house shown in Fig. 128.

in the summer when it is desired to pasture the herd.

The illustration shows a small wing attached which may serve many useful purposes. A matched upper floor and abundant light and ventilation should be provided. The roof story 
may be used for housing some corn in the ear and straw for bedding. In cold weather the upper floor should have some straw left on it to promote warmth in the pens below.

The object in discussing these three styles of piggeries has been to emphasize cleanliness, economy of labor in caring for the animals, the comfort of the animals, prevention of wanton waste of manure, and economy in the production of healthy swine in piggeries so arranged that the animals may be conveniently grazed during the summer, and kept reasonably clean and comfortable in winter.

THE SILO

The Egyptians, the Romans, and the American Indians all stored grain in pits or silos which were air-tight, or as nearly so as large rude structures could be made. The custom of using silos for storing grain in Spain and France never became common, though several attempts were made to preserve large quantities of grain for several years, that the overproduction of one year might be kept until there were deficient harvests.

The subject of ensilaging green "roughage" material attracted attention in the United States soon after 1870. As early as 1875, Doctor 
Manly Miles, then connected with the Illinois Industrial University, was fairly successful in preserving the green tops of broom corn in an earthen silo. Interest in the subject of preserving green material in silos was widely aroused in America by the appearance of a book on ensilage, translated in 1878-9. The book was published in France in 1877, by M. Auguste Goffart.

When the practice of ensilaging green material for feeding animals was first introduced into the United States there was much discussion as to the construction of silos. Many advocated building them of stones, brick, or grout, though some were built of wood. As a rule, they were built either square or in the torm of a parallelogram, in a few cases octagonal. Experience soon showed that the silage was preserved better in the wooden silo than in those constructed of other material. For this reason, and because the wooden silo is most cheaply constructed, wood is now in universal use for building them.

At first heavy frames were erected which were covered with two, three, and even four thicknesses of boards. Sometimes building paper was placed hetween the inner and outer boards. The octagon and the round silo soon supplanted those having square corner's. As 
built, too often the walls could not be or were not fully ventilated. The thick walls remained more or less damp throughout the entire year or, if dried out when empty, lack of ventilation superinduced dry rot. Cases were not infrequent where silos were found to be practically useless without rebuilding in four or five years. Where everything was at its best, the frequent shrinking and swelling of the wood resulted finally in so destroying its elasticity that it did not return to its normal size when the silo was refilled. Since there was no means of tightening these silos the air soon entered them freely, which resulted in serious loss of fodder. By reason of the costliness and defects of stone and grout silos, and the failure in many cases of squarecornered wooden ones to preserve the material satisfactorily, and because of their perishable nature, much attention has been given to the shape and material of silos.

From all the evidence attainable, the conclusion is reached that the round, tall, stave silo is best. It is simple in construction, inexpensive as compared with most other kinds, and reasonably durable. The fact that it dries out fully during the summer, thereby destroying all germs of decay, coupled with the other fact that at any time it can be made tight by means of the hoops which serve to hold the staves in place, 
makes the round, stave silo par excellent. The staves should be two inches thick and from four to six inches wide, bevelled to suit the size of the structure. The hoops are usually of round

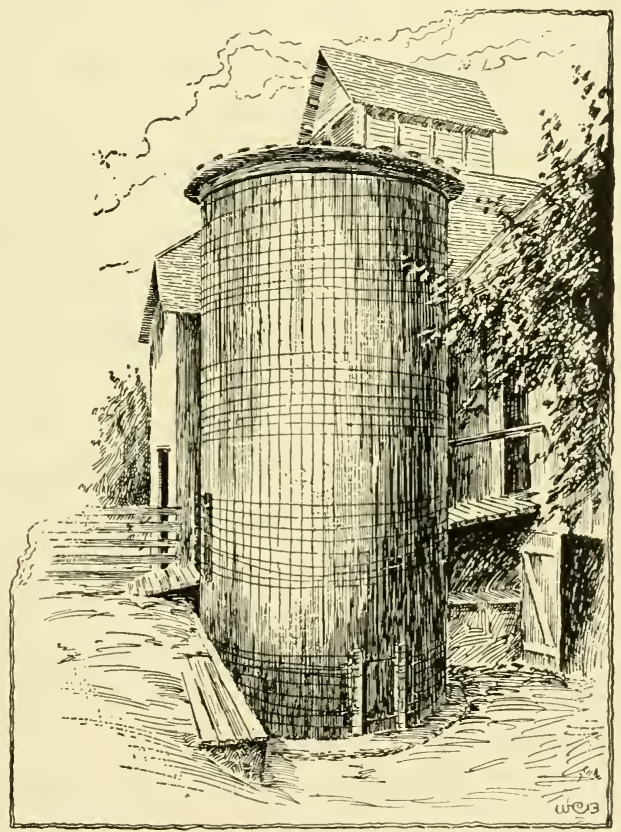

Fig. 130. The stave silo.

galvanized iron one-half inch in diameter. They are placed about three feet apart, the spaces between the hoops being wider near the top than they are near the bottom. The hoops are made in sections of variable lengths; the 
ends of each section are furnished with lugs, that the hoop may be shortened and the silo tightened with ease. The illustration (Fig. 130) shows an emergency silo built of rough green hemlock plank unbevelled, hooped with "American woren wire fence." It is 24 feet high, 12 feet in diameter, cost $\$ 35$, and has a nominal capacity of 50 tons. A flat board roof serves to keep out the snow and most of the rain. It is placed in the open to test its durability. It has been in use one year, and so far it is entirely satisfactory, though the staves would be better if they had been beveled.

How long will this inexpensive silo last? That remains to be determined. Judging from other silos of similar construction which were erected several years ago, I judge it will last 15 or 20 years with slight repairs. When left thus exposed, will the silage freeze during the winter? In extremely cold weather in central New York, when the thermometer drops to $10^{\circ}$ or $15^{\circ}$ below zero, the material at the top will freeze. If straw be spread over the silage to the depth of a few inches, it will prevent the escape of heat and freezing. A portion of the straw covering is thrown back out of the way, the silage wanted removed, and the covering returned. Such precaution is only necessary during a few of the coldest days. 


\section{CHAP'TER XX \\ PROTECTION FROM LIGHTNING}

A FLASH of lightning is one of the most feared of nature's manifestations of power; and yet by the use of proper precantions its ability to injure persous and property can be lessened greatly. Speculations as to the nature of lightning were vague until Benjamin Franklin boldly sent a kite into the teeth of a storm and tapped the accumulated electricity in the cloud to charge one of his storage jars. He connected the cloud with his jar by a wire made of a material which he knew would conduct the electrical charge, and at the same time he took the precaution not to hold the end of this wire himself. He introduced between the end of the wire and his hand a piece of silk cord, which is a non-conductor of electricity. Had he taken hold of the end of the wire, the charge would have passed through him with probably fatal results.

What is lightning? One naturally inquires for the reason of this storage of electrical energy in the clouds. The explanation is not 
forthcoming - at least there is none which is entirely satisfactory - but the facts are well known. The mass of water-vapor which forms the clouds becomes electrically charged just as a rubber comb does when rubbed on the hair on a dry day, or as an ebonite ruler does when rubbed on a cat-skin. Perhaps by contact with the air, which is in motion, the particles of water become charged, and by the union of multitudes of these the clouds are charged to a tremendous pressure. Lightning can be produced artificially on a small scale by means of electric machines, and the results of study of these artificial discharges have been to show the following facts: The air is not a conductor of electricity, but when the electrical pressure between two points becomes sufficiently great the electric charge jumps suddenly between the two points at which the pressure exists. It punctures a hole for itself through the air. Lightuing is the result. This discharge is very violent, and it is accompanied by a strong smell of ozone, which is only rery strong oxygen. If one were to examine the points of the electric machine between which the discharge took place, they might be found either hot or cold, depending upon their size and the material of which they were made. Some materials offer more resistance to the 
passage of the electric charge than others, and when a considerable resistance is offered, heat is produced in appreciable amounts at the places at which the resistance is met. The application of this principle will be seen when the effects of real lightning are considered.

In Figs. 131, 132, and 133 are shown lightning flashes taken by Mr. W. N. Jennings.*

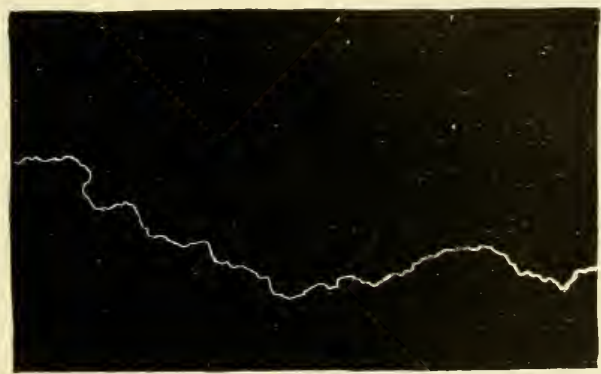

Fig. 131. Horizontal discharge of lightning.

'These flashes are so soon over' that without the aid of the sensitive photographic plate it would be impossible to study them. It will be noticed that the path of the charge is not straight, but quite irregular; this path being that in which there is the least resistance to the passage of the electricity. One strange phenomenon which is brought out clearly in the pictures is that the discharge rery frequently

*These three pictures are drawn, by permission, from photographic illustratious by Mr. Jennings in Journal of the Franklin Institute, vol. 133 (1892). 
divides into several branches. This is because it finds easy paths in several directions and divides into smaller discharges, thus finally disappearing.

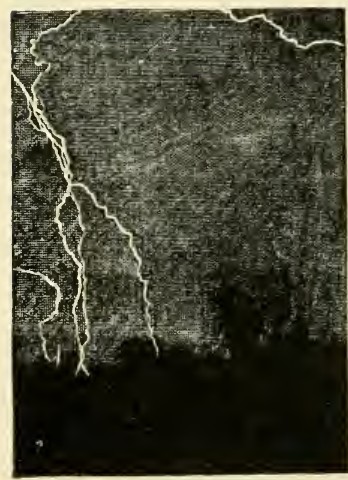

Fig. 132.

Neandering discharge.
Protection from lightning. - Having noticed briefly something of the nature of lightning, the next point to be considered is its control, so that the dangerous effects of a sudden discharge may be avoided. It has long been known that by repeating Franklin's experiment and connecting the clouds with the earth, dangerous flashes of lightning can be avoided to some extent; and this fact has given rise to much swindling on the part of the "lightning-rod man," who has frequently imposed on the people through their fear of the results of lightning bolts. Any person of average intelligence, with the knowledge of a few simple principles, can put up a rod himself for the protection of his barn or dwelling at a very reasonable expense.

\section{METAL ROOFS}

It has been noticed that metal roofs protect buildings even when no lightning rods are used, 
especially if there are tin or iron water pipes rumning to the ground. Even steam and gas pipes are good if connected with the roof. Tin and copper roofs are not so common in the country as in the city, and this is one of tine many reasons why city houses are less frequently struck by lightning than country ones. Copper roofs are not used now as they once were on account of the great expense; but from the electrical standpoint they are an excellent protection to a house in a thunder storm. The writer has noticed in a room in a city house, in which steam heat is used, that the lightning will come in and down on the steam pipes without doing any harm. If one will go into a telegraph station during a storm he will frequently notice the discharges of lightning which take place through devices provided for the pur-

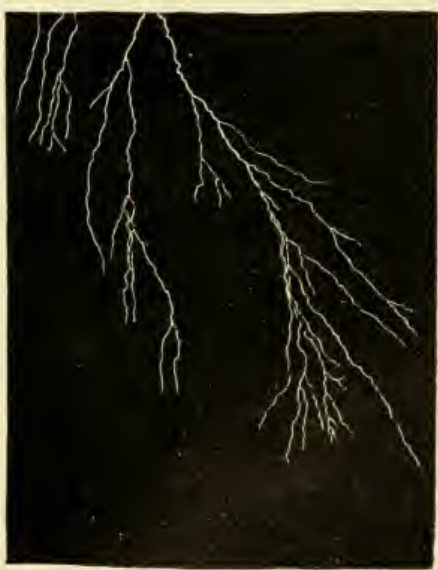

Fig. 133. Tree-form dischargo. pose, and this without the least fire risk. This is an illustration of the fact that, if properly provided for, the dangerous element 
can be largely eliminated from a lightning discharge.

\section{PRO'TECTING WOODEN ROOFS}

If a metal roof is out of the question, the protection of the wooden roof must be provided for. Very little attention has been paid in this country to the proper erection and maintenance of lightning rods. It is not sufficient to put up a point in an out-of-the-way place, and with a careless ground connection, and then expect immunity from lightning. The lightning rod will protect a wooden-roofed building if it is properly installed; and in order that this simple but important piece of apparatus be thoroughly understood it will now be considered in detail.

In the first place, it should be noted that there are two forms of electric discharge or lightning which are provided for in equipping a building with lightning protection: the brush discharge and the disruptive discharge. The brush-form is so named because the fine streamers of sparks which are emitted have somewhat the appearance of a brush. This discharge is harmless, and one of the important functions of the bunch of points on the upper. end of the lightning rod is to quietly take from the surrounding atmosphere the electricity there 
generated, and thus prevent its accumulation to a dangerous extent. Very high towers, such as steel windmills, high trees, and steeples do the community a good service in this respect. But sometimes the discharges cannot be dissipated through the brush form, but reach a high pressure, and exhibit themselves with great violence, producing the booming and crackling noise of thunder. This is the second form; and although the points may be useful in this case too, yet if they are too far apart the discharge may not seek them, but may take a shorter path through the moist hay from which the hot, damp air is rising to the roof and forming another lightning conductor. Protection from this can be partly provided by the use of several points, not over forty feet apart; but in cases in which lightning is very violent and frequent, the conductor should be run all around the edges of the roof, and in several places to the ground.

An experiment made by a noted electrician some years ago will illustrate this point: A frame was made of iron wire in the sliape of a barn, the wire representing the erlges of the walls and roof. The frame was comnected to the ground, or "grounded," as the electricians say, and then artificial lightning was allowed to play upon it from a distance of a foot or more above. This gave a model about in proportion to the 
real barn and actual lightning. All the discharge followed the wire frame, and did not ignite a dummy of gun-cotton which was placed inside. The instant that the metal barn frame was removed the dummy was struck and burned violently. One can draw his own conclusions from an experiment of this sort.

A barn properly fitted with lightning rods is shown in Fig. 134. The location of the points is such that there is not more than forty feet between two adjacent ones. The rod projects about six feet above the roof, and these projections are all connected by means of rod of the same form as the vertical conductors. Sharp turns are aroided in erecting the conductor, for an electric discharge would prefer to go straight through the air rather than turn a corner.

It will now be necessary to go into some practical details of the construction of lightning rods, and the suggestions that will be made have been included here because good points or rods may not always be readily obtainable. Their manufacture is easy and can be performed with the limited facilities of a small village. If the raw materials have to be bought at a distance, this can be easily done by correspondence.

Parts of the system: The equipment will consist of three parts-the conductor and its support, the points, and the ground connection. 
The conductor, or so-called "rod," first demands attention. All metals conduct electricity to some extent, but certain ones are very much better than others. For example, lead, platinum, brass, and iron are poor conductors, which

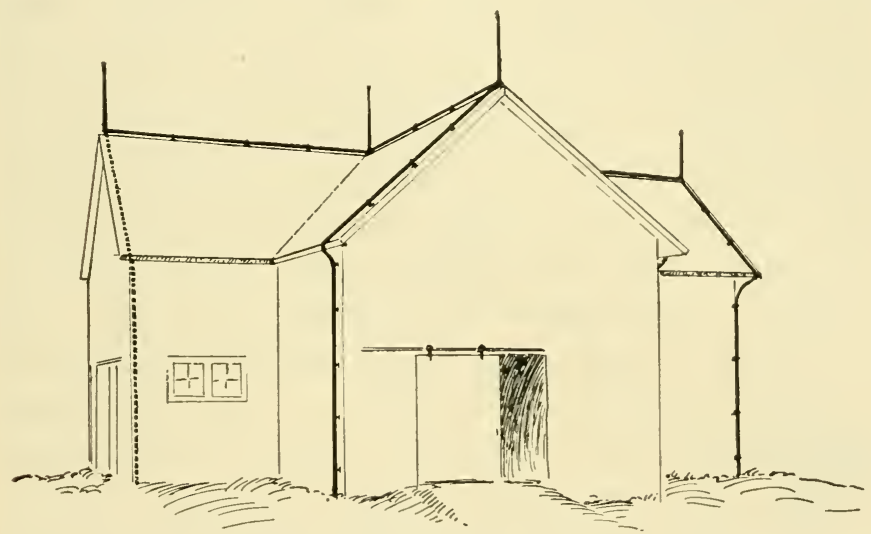

Fig. 134. Proper adjustment of lightning rods on a barn.

is equivalent to saying that they heat up readily on the passage of an electric current. On the other hand, silver, copper, and aluminum are good conductors. In making a lightning rod, the best all-round conductor should be used, when cost and conductivity are the basis for the selection. As an example, take the metals iron, copper, and aluminum for comparison. Iron is cheapest in price per pound, but its electrical conductivity is small, while copper, though more 
expensive, has so much more conductivity that to get rid of a certain charge of electricity requires much less of it. So with aluminum, which has slightly less conductivity and which costs more than copper, but which is so light that a rod having the same conducting ability when made of this metal actually costs less than one made of copper, and the price of aluminum is comstantly lessening, while that of copper cannot fall much on account of the limited supply. 'To compare actual figures, call the conductivity of copper 100, then that of steel or iron will be about 18, and that of aluminum about 60 . As to relative weights, copper weighs about 5.50 pounds per cubic foot, iron or steel 480, and aluminum 160. As the prices of these materials are constantly varying, it would be impossible to say at this time what the relative costs would be at any other time; but it can be said that on the score of cost there is little choice among them. For a number of reasons aside from cost, copper is at present the best material, and these reasons are: That it is smaller than the others for a given conducting ability, and thus is more sightly; that it is easier to support on account of this small size, and that it can be readily soldered to the ground plate, which will be considered later.

In addition to the material of the lightning 
rod, its form is a matter of considerable importance. The cable forms have been used extensively and successfully, but the ribbon or flat form is better on account of the smaller cost, and because there is a greater area exposed for the dissipation of the heat generated by the lightning in passing from the points to the ground. A rectangular section of three-quarters by one-eighth of an inch is recommended.

In supporting the conductor from the wall or roof, it should be separated or "insulated" from these surfaces. There is a slight chance that the lightning might leave the conductor if the building were wet. A more important reason for the use of the insulator is that the heat which is generated on the surface of the rod when a heavy discharge occurs will not be able, if supported away from the wall, to heat up any inflammable material near it. Fig. 135 shows a method of support in which one of the standard insulators used in running electric light and other wires is

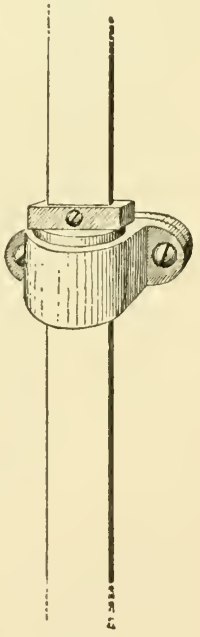

Fig. 135. employed. These insulators, which supporting it rod. are made of porcelain and iron, can be screwed into the wood or into a plug driven into the joints between the stones very readily. 
The insulator shown is manufactured by the General Electric Company, of Schenectady, New York, and similar ones are made by other manufacturers of electrical materials.

In order to attract the discharge, the ruds must project some distance above the roof, about 6 feet being the proper height. This projection must be supported, and there are two ways to do this. The first is to screw or nail a piece of timber to the side of the building, projecting about 5 feet above the roof. Two insulators on this will provide the necessary support for the rod. As this might be considered unsightly in some places, a neater but more expensive method is to use a piece of $3 / 4$-inch copper, brass or iron rod for the upper 9 or 10 feet of the rod. This can be easily joined and soldered to the copper ribbon and is strong enough to support itself in any wind. A brace from the vertical to the horizontal rod will provide additional support if desired, and will give a more substantial appearance. At the point at which the horizontal rod passes through a timber support, in case such plan is used, a hole $1 \frac{1}{2}$ inches should be bored in the timber to avoid any risk of its being burned. In joining the horizontal to the vertical rod, the former should be bent up at right angles for an inch, and the surfaces should then be well cleaned and soldered. 
The points for attracting the discharge should be made very carefully, and with a view to accommodating the brush discharge particularly. As a rule, the more points in the bunch at the head of the rod the better will the brush discharge be attracted; and for the same reason these points should be sharp and bright. These facts have been determined by experiment, from which it has been learned that the discharge is quieter and at a lower pressure from sharp, bright terminals than from others. Aluminum wire fulfils the requirements for the points better than any other metal of reasonable cost. Unfortunately this metal is difficult to solder, but if the directions here given are carefully followed there will be no difficulty in producing a good bunch.

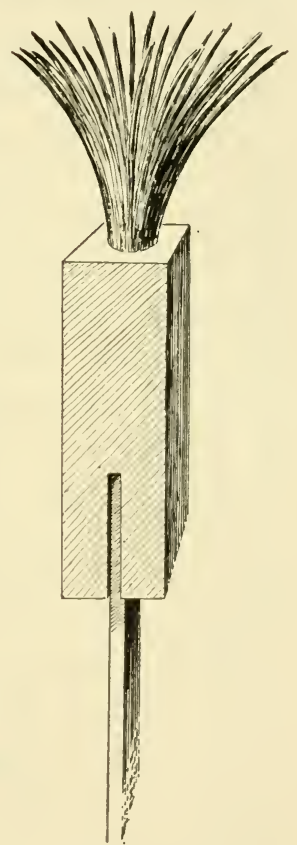

Fig. 136. Efficient points for a lightning rod.

The sketch (Fig. 136) shows the general construction. In the end of a block of copper of the dimensions shown, drill a hole $5 / 8$ of an inch in diameter and 1 inch deep. Cut off a number of pieces of aluminum wire, of about $1-16$ of an 
inch in diameter, about 4 inches long. This wire can be obtained from the Pittsburg Reduction Company, of Pittsburg, Pennsylvania. These wires must then be filed to sharp points on one end, the opposite ends being roughened with coarse sandpaper. Push as many of the wires into the hole in the block as it will hold and bend the points back so as to form a brush. Now heat some solder in a ladle and pour in around the lower ends of the almminum wires, having first taken the precaution to heat the copper block so that the solder will flow well. The conductor rod is then soldered into a slot filed in the lower end of the block, and the bunch of points is complete.

The ground comnection is the most important part of the whole equipment. With poor ground comnections, the rods become a menace to a building rather than a protection. Examples could be cited where buildings were actually struck and destroyed, even though "apparently properly rodded." In one case the wire entered but two inches into dry soil, while in another the lower end was buried in concrete. It is absolutely essential that the lower end of the rod be comnected with moist earth in some way, as this is the only methor which will insure safety. If there are water pipes in the building, they should be attached to the 
rod in the basement in addition to the main ground connection.

As the charge is to be dissipated in the earth, it will be necessary to expose a considerable area of metal under ground. If a spring is near, the rod should be run to the vicinity of the spring and there soldered to the ground plate, which should be below the level of the surface of the spring. Moist soil is the only kind which will conduct electricity, hence the insistence on a moist place for the terminal of the rod. In case the plate must be planted some distance from water, either it must go quite deep or it may be placed in a barrel of charcoal or coke buried under the surface. These materials will hold whatever water they receive, and it is a simple matter to wet the soil above such a terminal from time to time. The plate itself should be of copper and of an area of at least 25 square feet, including both sides. An old copper boiler, flattened out, makes a cheap and effective ground plate.

There is no doubt that many buildings have been saved from destruction by means of properly installed lightning rods, and it is plain that they are not difficult nor expensive to install. 


\section{CHAPTER XXI}

THE FIELDS

While it is the primary object of this book to discuss the lay-out of buildings and their accessories, it would be incomplete if something were not said of the general plan of the fields themselves.

\section{FENCES}

Some ten years since, someone estimated that for every dollar's worth of live stock kept in New York another dollar was expended in fences to restrain it. It is probable that this estimate is below rather than above the facts. Be this as it may, the first cost of fences and their maintenance is a serious draft on the resources of the farmer.

In the pioneer days, when even the best of fencing material was so abundant that it was burned to clear the land, there was great temptation to split the tender logs into great rails and construct fences with them. Each winter a few acres of land were cleared and each year's clearing was surrounded by a great ten-rail fence, 
which served to discourage some of the larger wild animals from destroying the crops. It is easily seen why our ancestors in the wooded districts fenced the farm into small fields. In some cases the surface stones were so numerous on the land that the larger ones had to be removed to make way for the plow. Naturally they were used for constructing fences, for the most economical way to get rid of these too numerous stones was to make fences of them. The haul was short and the fences could be increased in width and height until storage room was provided for all the rocks which the farmer cared to remove. So here, too, the temptation was great to fence the farm into small fields. The following diagrams show the fields and the fences as they were on the old homestead, and also as they are at the present time (Fig. 137).

Changed agricultural conditions imply fewer fences and the adoption, in part at least, of the soiling system. Then, too, the introduction of the horn-fly makes a radical change imperative in the summering of the dairy. This worst of all dairy pests robs the cow of flesh and the owner of profit.

Now that the silo is an assured success, except under rare concitions, soiling, or the partial soiling system, should be adopted on 
many farms, especially in the dairy districts. The object should be to provide a continuous and full supply of food, and comfortable conditions for the animals

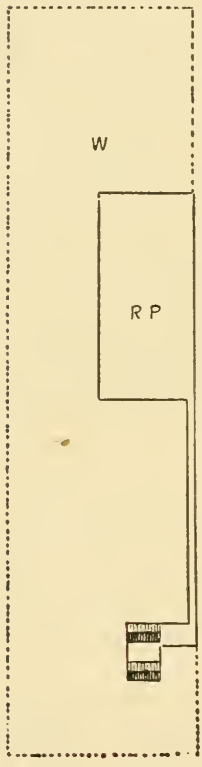

W-Wood

RP-Rough pasture

W

$R P^{\circ}$

Fig. 137. The old-time fence system on the right; the present condi. tion on the left. at all times. In May and June the pastures are succulent and the grasses usually abundant, and the annoying flies are not present. When the animals are first turned out on the pastures the nights may be too cold and damp for comfort, in which case they may be stabled and fed a small supplemental ration; in fact, cows in milk should always receive some dry, concentrated food for the first few weeks after they are turned out to grass. Often

the early grass is over-succulent and deficient in food constituents to such an extent that the cows cannot eat enough to sustain life and produce the most profitable quantities of milk. When the pastures begin to fail, the flies appear 
and the days are hot, manifestly the animals will be most comfortable in the stables in the day time and in the pastures at night. This system will permit of reducing the pastures nearly one-half, and the removal of all fences except those which surround the permanent pasture land. If it is desired occasionally to pasture a part of the unenclosed land, a light woven wire fence, which can be easily erected and removed, may be constructed. All changes in the present system of summering animals should be towards smaller areas of pasture-land, fewer fences, more comfortable conditions for animals, economy of effort, and control of food-supplies for the animals at all seasons of the year.

In most of the states the laws require each farmer to restrain his own animals without the aid of the neighbors; hence the road-fence, often the most unsightly and ill kept of all the fences, may be discarded. How many of the inside fences would best be removed depends upon circumstances; but certain it is that a more rational system of restraining and feeding cattle will be adopted than the one now almost universally in use. We cannot destroy the hornfly; we can remove the useless fences and house the animals in stables from which the pestiferous flesh- and milk-reducing flies are excluded. 


\section{ORCHARDS}

In some fruit districts the farmers are cutting down their orchards, saying that they cannot afford to bother with them, and that fruitraising must be carried on in a large way by specialists to be profitable. This is tantamount to saying that they are not intelligent and enterprising enough to manage six or eight acres of orchard successfully, while their neighbor is competent to care for ten times that acreage. The man who owns the smaller orchard should, other things being equal, secure a relatively larger profit than the owner of the large orchard, since he will be able to give it more personal attention. The man who overcomes the difficulties of fruit-raising is constantly adding to his education and power, while the man who is appalled with the difficulties of orcharding, and falls back on rye, buckwheat and oats as money-crops, sinks in intelligence and loses courage. The orchard, when intelligently cared for, seldom fails to give much larger profits than a like area devoted to the cereals. As a rule, the most difficult crop to raise or the most difficult business is the one which brings the most liberal reward after the difficulties have been surmounted.

When convenient, the orchard might well be 
set to the north or west of the buildings, in most sections of the United States, but not so close to them as to prevent a good air passage between it and the dwelling. Low-headed fruit trees should not be set in the. house yard or near to it. The trees in most orchards are set too close together, and even when set appropriate distances apart it will be found to be unprofitable, in the long run, to grow two erops on the same land at the same time, as wheat or oats and apples. Specific directions for the care and management of orchards can now be found in well written books and bulletins; therefore there is no occasion for treating orchards in detail here. Suffice it to say that the farmer without an abundance of fruits in their season is like the lad with empty pockets outside the circus tent: lots of fruit and fun, ready to be enjoyed by those who have made thoughtful provision for the gratification of desires which always come, sooner or later. Every farmer should grow most of the fruits suited to his soil and climate,-enough to eat and to sell and to give to the worthy poor.

\section{FARU GARDEN}

The farm garden should be ample and contain not only enough vegetable and small fruits for the use of the family, but a surplus to sell 
or to give away. The farmer used to large areas is reluctant to undertake anything so small as he imagines the garden to be; hence, too often he plows it and leaves the planting and cultivation of it to the "women folks." If he knew how to manage a garden he would find that the half-acre of land devoted to small fruits and vegetables could be made the most profitable and pleasurable part of the farm. Higher remuneration is received for the time spent in harvesting the products of a large, well kept garden, than in harvesting the cereals or milking the cows. It must be said, however, that there are good reasons for the farmer's distaste for gardening, for the gardens, as usually laid out, necessitate the maximum of hand-culture and the minimum of horse-culture. The result of such gardens is a minimum of products secured by maximum of effort, and a resultant surplus of weeds.

The garden should be about four times as long as it is broad, unfenced when possible, near to the house, and should be, in miniature, a farm with the cereals, grasses, and large fruits left out (Fig. 138). The side farthest from the dwelling should be devoted to the perennial plants, such as grapes, currants and other bush-fruits. Everything should be planted in straight rows, with spaces sufficiently 
wide between the rows to admit of horse-hoe culture. The grapes and blackberries might occupy one row, the raspberries and currants a second row, rhubarb, asparagus and like plants a third row. The spaces between these

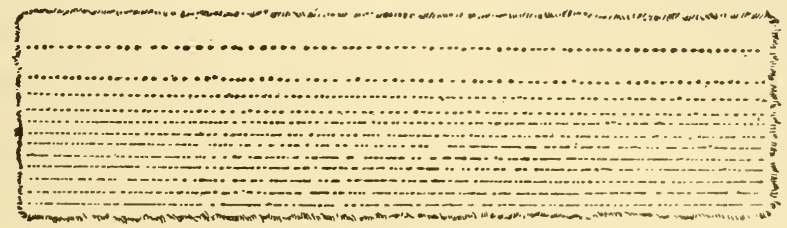

Fig. 138. Plan of a home garden.

various fruits should be eight feet, as it is poor economy to so crowd vines and bushes as to force them to struggle the year through for plant-food and moisture. A rod or two of land, more or less, virtually amounts to nothing on the farm; crowding the plants is only admissible in the city or village. Here the plants may receive unusual care, and often may be irrigated at fruiting time from the city hydrant. The rows of ordinary vegetables may be thirty inches apart, except in case of such plants as onions, lettuce, and early beets. These small, slow-growing esculents should be planted in double rows. Starting from the last row of potatoes a thirty inch space is measured off, a row of lettuce planted, and then one foot from 
this a row of beets or onions; then leave a space thirty inches wide and again plant double rows, if more of the small esculents are wanted. The larger spaces may be cultivated by horsehoe and the smaller spaces by hand-hoe. The entire garden which is to be planted in the spring should be kept fertile and plowed early in the spring, leaving that part of it which is not designed for immediate planting unharrowed. It may be necessary to replow. It certainly will be necessary to cultivate several times that part of the garden which is used for late-growing crops, such as cabbage and celery. As a rule, the farmer cannot afford to attempt to raise two crops on the same land the same year, since labor is everything and the use of land nothing; therefore, better prepare the ground by two or three plowings for the late crops, than to attempt to raise them on land which has parted with much of its readily available plant-food in producing the early crop. Then, too, land which has produced one crop is likely to be deficient in moisture, while land that has been plowed two or three times during the summer and kept well harrowed will be moist and contain an abundance of readily available plant-food. Early in the spring, when the land is cold and often too moist, it is best to leave the soil rough for a 
time if it is not to be planted immediately, that it may become somewhat dry and warm. As a rule, the garden should not be fenced, but the chickens should be restrained by fences a part of the time; at other times they may have free access to the garden, where they are often very beneficial in reducing the insect enemies. 



\section{INDEX}

Abandoned lands, significance of, 31 .

Agrieultural statisties, 8; what they do not show, 10.

Agriculturists, what they have done, 8 . Air space required in cow stables, 281. Anglo-Saxon, cause of superiority, 50 .

Animal, necessity of exereise for, 278; voidings, how cared for in stables, Asphalt for stable floors, 292.

Bailey, Professor L. H., quoted, 7.

Bailey, chap. xiv, 237.

Balloon frames, 129.

Barns, 288; basement, location of, 268; building the basement, 266; connected by covered way to house, 257; discussion of, 249; distance to locate from house, 257; economy in construction, 253; excavations for, 268; high large ones preferable, 253; location of, 255; octagonal, discussion of, 254; planning, 259; size required, 249; water supply for, 261; why large ones are required, 250 .

Barnyards, open ones objectionable, 258; paddocks are preferable to, 259.

Basement barns, bridging for, 269; loeation of, 268; on level ground, 269; Hoors, how to construct, 277; walls, how to prevent dampness on, 275 ; wood preferable to stone, 275.

Beauty and utility should be com. bined, 107.

Bonanza farming, cause of decline. 36-38.

Brick used in stable floors, 278.

Building the barn, chap. xvii, 288; framiug, 289; horse stables, 294; lightning rods on baris, 296: painting the barn, 296; plank frames, 290 ; protecting the root-cellar, 289; repairing old barn floors, 293; roof of barns, 296; stable floors, 292; willdows, 295.

Cattle, stanchions for, 284.

Cement, Portland, cost and mixing of, 274 ; proportion of, to sancl in mortar, 273.

Changes in houses, considerations, 85. Children, eity and country compared, $\overline{3}$. Cisterns as a source of water supply, 263.

Cleanliness, and sanitation, water supply and sewage, chap. xii, 204; bacteria, harmful and beneficial, 204-206; bath room, 210; bath tubs, 213; cess pools, 220; closets, 210; disinfectants. 207; dry-earth elosets, 222; kitchen sink, 212; laundry, 214; outhouses, 216; personal cleanliness, 209 ; pipes. 212; sewage, 219; water closets, 214; water supply, 217.

College buildings and what they illustrate, 104.

Colleges. Land Grant, aim of, 14; enldowment, 14; data of incomes, 1.).

Competence, how obtained, 20.

Concentration of barns, 84 .

Counsel at the right time, 69.

Country ehurches, 119.

Country life, what it stands for, it; what things have no place in it, 74 . Country school houses, 119-122.

Cows, air space required for, 280, 281; mangers for, section of, 286 . 
Crops, good and poor, 27; specialized, baleful results of, 33 .

Dams for artificial pools, how to construct, 262.

Decorations inside, 193.

Deeds and abstracts, 67 .

Demolins, $\mathrm{MI}$, quoted, 50.

Economy, 224.

Educating the eye and judgment, 107.

Education, by contact with nature, 4;

higher, conceutration necessary, 52;

higher, in the past, 13; industrial, 14.

Evolution of high wages, 25.

External construction, principles of, 108.

Farm buildings, concentrated and distributive, 251; concentrated sýstem preferable, 252; examples of mistakes, 89.

Farm laborers, wages received by, 253 .

Farmers' contribution to economic status of the United States, 9.

Farms, selection of-elimatic conditions, 55; cheap lands, 56; water supply, 57 .

Farms overloaded with buildings, 88 .

"Farming doesn't pay," 6.

Fences, 336.

Fields, the, chap. xxi, 336 .

Filigree work, not for farm houses, 96.

First impressions, 116.

Floors, basement, how to construct, 277 ; cows to stand upon, 280; stable, wooden ones preferable, 278.

Foundations for buildings, how squared, 266.

Foundation walls, properly and improperly bonded, 272.

Frost pockets, 76 .

Furnishing, 193.

Garden, farm, 341; planting the, 342.

Gingerbread cornices, 130.
Ground floor unhealthy, 77 .

Gypsum, use of in stables, 277.

Heating. 190.

Home education suggestions, 48.

Home, old (should be preserved), 112;

suggestions for improvement of, 113.

Home training, 46.

Homestead, improving the old, 114 .

Horn-fly, reference to, 337 .

House, building the, chap. viii, 132; brick and stone houses, 169 ; chim. neys-flue linings, 140, openings for, 141 ; excluding vermin from the, 135 ; foundations, building the, 138 ; mortar for foundations, 139 ; protecting from frost, 136 ; the cellar, 133, 134. Wooden houses-the frame, 142 ; bridging the joists, 143 ; eutting braces and rafters, 150; diagonal boarding, 144; girders for secondstory joists, 145 ; made-up timbers, 146; old houses, 170; roofs-kinds of, 147 , piteh of, 149 ; studding, size of, 143; the story-and-a-half, 155.

House furnishing and decoration, chap. xi, 193 ; carpets vs. rugs, 196 ; decorations, 200; draperies, 198; general principles, 193-196.

Honse, location of, 74; extremes, 75; on elevated lands, $76,80,82$.

House of pioneer, where located, 75.

House, old farm, an example of a good, 90-91.

House sites-old and new, 84.

House sites to be avoided, 82; near middle of estate, 83; and highway, 83.

House with many gables, 96 .

Houses, exposed and overshaded.117, 118; planning, 94 ; studying other models, 95; useless cost of, 95 .

Houses, farm, not a direct source of income, 87; mistakes $\Gamma_{\text {-in }}$ building, 87 ; what they are for, 87.

Houses, old farm, 85.

Houses, veneered, 168. 
Household administration, economy and comfort, chap. xiii, 224; a definite income, 225; bargain-hunting, 229; cash vs. credit, 286; economy of health, 232; keeping accounts, 230; reading matter, 235; systematic buying, 227; the farmer's diet, 234; the wife's share, 225 .

Improvements on the farm, 59 .

Inappropriate styles of architecture, 124.

Inside finish, heating and ventilation, chap. $x, 181$; baseboards, 183; facings, 186; finish, hard oil, 186; floors, 182 ; patent mortars, 188; plastered walls, 186-188; picture moulding, 184; stairs, 185; wainscoting, 185 . Heatingsteam recommended, 191; systems of, compared, 190. Ventilation, 191.

Land for market-gardening, 61 .

Lands, cheap, 56.

Lawns, 243.

Lawyer and the farmer, 73 .

Lawyer, province of the true, 72 .

Lawyers, 65.

Level country, disadvantages of location in, overcome, 78 .

Leisure and study, 13.

Light and air, 106.

Lightning, artificial, 322 ; brush discharge, 326 ; discharges, 323 ; disruptive discharge, 326 ; protection from, 324 ; protection from by metal roofs, 324 ; protection from by steam and gas pipes, 325 ; protecting wooden roofs from, 326 .

Lightning protection, chap. xx, 321 .

Lightning rods, 328-336; insulation of, 331 ; joints for, 333 ; the condnetor, 329 ; the ground comnection $\$ 334$.

Lime, proportion of, to sand in mortar, 273.

Lime, stone, retail price of per bul., 274; water, retail price of per bul.,274.

Lumbering, effect of, 38 .
Manger for cows, cross-section of, 286 ; how constructed, 285 .

Market-gardening, land for, 61 .

Mistakes in locating, 100.

Mortar, amount of water to use in mixing, 275; how to $\mathrm{mix}, 273$.

Nature study, 111.

Newton cattle tie illustrated and described, 286.

Norris, H.H., chap, xx, 321.

Occupation, selection of, 21 .

Old barns, remodeling, 298 .

Orchards, 340 ; care of, 341 .

Outbuildings and accessories, chal). xix; 306 ; piggeries, 311 ; portable coops, 309 ; poultry houses, 306 ; the silo, 316 .

Outside covering, painting, chap. ix, 158 ; cornices, 164 ; painting the house, 173; adulterated paints, 179 ; analyses of paints, 180; oils for painting, 177; roofs-coustruction of, 165 ; shingles 165 , shingling 167 ; sidingnovelty and lap, 160 ; the projections, 158,164 ; the water-table, 158 ; valleys, 173.

Parents as teachers, 45.

Piggeries, 311.

Plain cornices, 126.

Plan, ground, not adapted to country, 98; adapted to country, 99, 101.

Plant-food, natural cheaper than artificial, 62 .

Pools in level country, 78.

Pools in the South, how constructed, 262.

Poultry Houses, 306 .

Quality in furm produets, 32 .

Red River valley soil, nitrogen in, 37 . Remodeling old barns, chay. xviii, 298; combining several old frames, $29 y$; form of roof, 302; trussing to elim1nate posts, 301 . 
Remuneration in agriculture, 7 .

Renter and renting discussed, 40 .

Road to farm, 63.

Road fences, may be discarded, 339 .

Root cellar, location of in barn, 270 .

Rosendale cement, proportion to $\mathrm{mix}$, 274.

Rural life; advantages and disadvantages, 2 ; greatest advantage of, 5 . Rural population, wants and aspirations, 19.

\section{Sanitation, 204.}

Scenery, natural, its value, 58 .

Schœenfield, Mr. G., an intensive agriculturist, 22; his crops and their value, 23.

School, district, sketch of a day in, 47.

School children, effects of massing, 44 . Schools, rural, 43.

Sewage, 204.

Shadows cast by walls, 106.

Ship coustruction of houses, 128 .

Silos, 316.

Silo, reference to use of, 337 .

Smith, Mrs. M. R., chap. xi, 193; chap. xii, 204; chap. xiii, 224.

Soil and subsoil for house location, 80.

Soiling system, referred to, 337,338 .

Stable floors, 292; wooden ones preferable, 278; drip in, how constructed, 280; how to secure sanitary conditions, in 277; stanchions for cattle, 284.

Stalls for cows, how constructed, 285.

Stock on the farms in U. S. in 1870 and $1890,250$.
Tillage, cost of, considered in land value, 62 .

Types of dwelling houses, 109.

Van Vleet, D. F., chap. v, 65.

Ventilation, 191; principles of, 283; secured by swing windows, 282.

Ventilators for stables, how constructed, 282.

Veranda-a poor example, 96 ; outlook from, 81 ; shading, 103.

Vistas and views brought into the landscape, 81 .

Warner, Prof. Amos G., quoted, 3.

Walls, stone, how to bond, 272.

Water for animals, temperature best in winter, 264.

Water supply and sewage, 204.

Water supply, artificial pools for, 262 ; for animals, should be in barn, 264 ; for buildings, 261; springs and streams, 264.

Water, cold, effect upon the animal, 265 ; lime, retail price of per bbl., 274.

Wells, 71.

Wheat, production and cost of, 30 .

Windows, swing, how constructed in stables, 282.

Writing, matters of importance should be in, 71 .

Yard (the house yard), chap. xiv, 237; driveways and walks, 239; flowers 247; planting, scattered and in groups, 339; the lawn, 243; vines and creep. ers, 247. 


\section{The Best and Nervest Rural Books}

DOOKS ON LEADING TOPICS CONNECTED WITH AGRICULTURAL AND RURAL LIFE ARE HERE MENTIONED. EACH BOOK IS THE WORK OF A SPECIALIST, UNDER THE EDITORIAL SUPERVISION OF PROFESSOR L. H. BAILEY, OF THE CORNELL UNIVERSITY, OR BY PROFESSOR BAILEY HIMSELF, AND IS READABLE, CLEAR-CUT AND PRACTICAL。 


\section{THE RURAL SCIENCE SERIES}

Includes books which state the underlying principles of agriculture in plain language. They are suitable for consultation alike by the amateur or professional tiller of the soil, the scientist or the student, and are freely illustrated and finely made.

The following volumes are now ready:

THE SOIL. By F. H. KING, of the University of Wisconsin. 303 pp. 45 illustrations. 75 cents.

THE FERTILITY OF THE LAND. By I. P. Roberts, of Cornell Lniversity. Fifth edition. 421 pp. 45 illustrations. $\$ 1.25$.

THE SPRAYING OF PLANTS. By E. G. Lodeman, late of Cornell University. 399 pp. 92 illustrations. $\$ 1.00$.

MILK AND ITS PRODUCTS. By H. H. WING, of Cornell University. Fifth edition. $311 \mathrm{pp} .43$ illustrations. $\$ 1.00$.

THE PRINCIPLES OF FRUIT-GROWING. By L. H. BAILEY. Fourth edition. $516 \mathrm{pp} .120$ illustrations. $\$ 1.25$.

BUSH-FRUITS. By F. W. CARD, of Rhode Island College of Agriculture and Mechanic Arts. Second edition. 537 pp. 113 illustrations. $\$ 1.50$.

FERTILIZERS. By E. B. Voorhees, of New Jersey Experiment Station. Third edition. $332 \mathrm{pp}$. $\$ 1.00$.

THE PRINCIPLES OF AGRICULTURE. By L. H. BAILEY. Third edition. $300 \mathrm{pp} .92$ illustrations. $\$ 1.25$.

IRRIGATION AND DRAINAGE. By F. H. King, University of Wisconsin. 502 pp. 163 illustrations. $\$ 1.50$.

THE FARMSTEAD. By I. P. RoBERTs. 350 pp. 138 illustrations. $\$ 1.25$.

RURAL WEALTH AND WELFARE. By GLORgE T. FAIRCHILD, Ex-Presi. dent of the Agricultural College of Kansas. 381 pp. 14 charts. \$1.25.

THE PRINCIPLES OF VEGETABLE-GARDENING. By L. H. BAILEV $468 \mathrm{pp}$. 144 illustratious. $\$ 1.25$.

THE FEEDING OF ANIMALS. By W. H. JoRdAx, of New York State Experiment Station. 450 pp. $\$ 1.25$ net.

FARM POULTRY. By George C. Watson, of Pennsylvania State College. 341 pp. $\$ 1.25$ net.

New volumes will be added from time to time to the Rural Science Series. The following are in preparation :

Physiology OF PLANTS. By J. C. Arthur, Purdue University. BREEDING OF ANIMALS. By W. H. BREWER, of Yale University. PLANT PATHOLOGY. By B. T. GALloWAY and associates of U. S. Department of Agriculture.

CARE OF ANIMALs. By N. S. MAYo, of Connecticut Agricultural College. THE POME FRUITS (Apples, Pears, Quinces). By L. H. BaILEY. 


\section{THE GARDEN-CRAFT SERIES}

Comprises practical hand-books for the horticulturist, explaining and illustrating in detail the various important methods which experience has demonstrated to be the most satisfactory. They may be called manuals of practice, and though all are prepared by Professor Baller, of Cornell University, they include the opinions and methods of successful specialists in many lines, thus combining the results of the observations and experiences of numerous students in this and other lands. They are written in the clear, strong, concise English and in the entertaining style which characterize the author. The volumes are compact, uniform in style, clearly printed, and illustrated as the subject demands. They are of convenient shape for the pocket, and are suiustantially bound in flexible green cloth.

THE HORTICULTURIST'S RULE-BOOK. By L. H. BAILEY. Fourth edition. 312 pp. 75 cts.

THE NURSERY-BOOK. By L. H. BAILEY. Fifth edition. 365 pp. 152 illustrations. $\$ 1.00$.

PLANT-BREEDING. By L. H. Bailex. 293 pp. 20 illustrations. \$1.00.

THE FORCING-BOOK. By L. H. BAILEY. 266 pp. 88 illustrations. $\$ 1.00$.

GARDEN-MAKING. By L. H. BAILEY. Fifth edition. 417 pp. 256 illustrations. $\$ 1.00$.

THE PRUNING-BOOK. By L. H. BaILEY. Fourth edition. 545 pp. 331 illustrations. $\$ 1.50$.

THE PRACTICAL GARDEN-BOOK. By C. E. HUNN and L. H. BAILEY. 250 pp. Many marginal cuts. $\$ 1.00$. 


\section{THE SURVIVAL OF THE UNLIKE: 1 A Collection of Evolution Essays Suggested by the Study of Domestic Plants. By L. H. BAILEY, Professor of Horticulture in the Cornell University.}

\section{FOURTH EDITION - 516 PAGES - 22 ILLUSTRATIONS - $\$ 2.00$}

To those interested in the underlying philosophy of plant life, this volume, written in a most entertaining style, and fully illustrated, will prove welcome. It treats of the modification of plants under cultivation upon the evolution theory, and its attitude on this interesting subject is characterized by the author's well-known originality and independence of thought. Incidentally, there is stated much that will be valuable and suggestive to the working horticulturist, as well as to the man or woman impelled by a love of nature to horticultural pursuits. It may well be called, indeed, a philosophy of horticulture, in which all interested may find inspiration and instruction.

The Survival of the Unlike comprises thirty essays touching upon The General Fact and Philosophy of Erolution (The Plant Individual, Experimental Erolution, Coxey's Army and the Russian Thistle, Recent Progress, etc.); Expounding the Fact and Causes of Variation (The Supposed Correlations of Quality in Fruits, Natural History of Synonyms, Reflective Impressions, Relation of Seedbearing to Cultivation, Tariation after Birth, Relation between American and Eastern Asian Fruits, Horticultural Geography, Problems of Climate and Plants, American Fruits, Acclimatization, Sex in Fruits, Norelties, Promising Tarieties, etc.); ard Tracing tho Erolution of Particular Types of Plants (the Cultivated Strawberry, Battle of the Plums, Grapes, Progress of the Carnation. Petunia. The Garden Tomato, etc.). 


\section{THE EVOLUTION OF OUR NA- TIVE FRUITS. By L. H. BAIley, Pro. fessor of Horticulture in the Cornell University.}

472 PAGES - 125 ILLUSTRATIONS - $\$ 2.00$

In this entertaining volume, the origin and development of the fruits peculiar to North America are inquired into, and the personality of those horticultural pioneers whose almost forgotten labors have given us our most valuable fruits is touched upon. There has been careful research into the history of the various fruits, including inspection of the records of the great European botanists who have given attention to American economic botany. The conclusions reached, the information presented, and the suggestions as to future developments, cannot but be valuable to any thoughtful fruit-grower, while the terse style of the author is at its best in his treatment of the subject.

The Evolution of our Native Fruits discusses The Rise of the American Grape (North America a Natural Vineland, Attempts to Cultivate the European Grape, The Experiments of the Dufours, The Branch of Promise, John Adlum and the Catawba, Rise of Commercial Viticulture, Why Did the Early Vine Experiments Fail ? Synopsis of the American Grapes); The Strange History of the MIul. berries (The Early Silk Industry, The "Multicaulis Craze,"); Evolution of American Plums and Cherries (Native Plums in General, The Chickasaw, Hortulana, Marianna and Beach Plum Groups, Pacific Coast Plum, Various Other Types of Plums, Native Cherries, Dwarf Cherry Group); Native Apples (Indigenous Species, Amelioration has begun); Origin of American Raspberry-growing (Early American History, Present Types, Outlying Types); Erolution of Blackberry and Dewberry Culture (The High-bush Blackberry and Its Kin, The Dewberries, Botanical Names); Various Types of Berry-like Fruits (The Gooseberry, Native Currants, Juneberry, Buffalo Berry, Elderberry, High-bush Cranberry, Cranberry, Strawberry); Various Types of Tree Fruits (Persimmon, Custard-Apple Tribe, Thorn-Apples, Nut-Fruits); General Remarks on the Improvement of our Native Fruits (What Has Been Done, What Probably Should Be Done). 


\section{ESSONS WITH PLANTS: Sugges- tions for Seeing and Interpreting Some of the Common Forms of Vegetation. By L. H. BAILEY, Professor of Horticulture in the Cornell University, with delineations from nature by W. S. HOLDSWORTH, of the Agricultural College of Michigan.}

\section{- SECOND EDITION-491 PAGES-446 ILLUSTRATIONS-12 MO- CLOTH-81.10 NET}

There are two ways of looking at nature. The old way, which you have found so unsatisfactory, was to classify everything-to consider leaves, roots, and whole plants as formal herbarium specimens, forgetting that each had its own story of growth and development, struggle and success, to tell. Nothing stifles a natural love for plants more effectually than that old way.

The new way is to watch the life of every growing thing, to look upon each plant as a living ereature, whose life is a story as fascinating as the story of any favorite hero. "Lessons with Plants" is a book of stories, or rather, a book of plays, for we can see each chapter acted out if we take the trouble to look at the actors.

"I have spent some time in most delightful examination of it, and the longer I look, the better I like it. I find it not only full of interest, but eminently suggestive. I know of no book which begins to do so much to open the eyes of the student - whether pupil or teacher - to the wealth of meaning contained in simple plant forms. Above all else, it seems to be full of suggestions that help one to learn the language of plants, so they may talk to him." - DARWIN L. BARDWELL, Superintendent of Schools, Bing. hainton.

" $\mathrm{It}$ is an admirable book, and cannot fail both to awaken interest in the subject, and to serve as a helpful and reliable guide to young students of plant life. It will, I think, fill an important place in secondary schools, and comes at an opportune time, whell helps of this kind are needed and eagerly sought."-Professor V. M. SPALDING, University of Michigan.

\section{FIRST LESSONS WITH PLANTS}

An Abridgement of the above. 117 pages-116 illustrations -40 cents net. 


\section{ROTANY: An Elementary Text for Schools. By L. H. BAILEY.}

355 PAGES-500 ILLUSTRATIONS-\$1.10 NET

"This book is made for the pupil: "Lessons With Plants was made to supplement the work of the teacher." This is the opening sentence of the preface, showing that the book is a . companion to "Lessons With Plants," which has now become a standard teacher's book. The present book is the handsomest elementary botanical text-book yet made. The illustrations illustrate. They are artistic. The old formal and unnatural Botany is being rapidly outgrown. The book disparages mere laboratory work of the old kind: the pupil is taught to see things as they grow and behave. The pupil who goes through this book will understand the meaning of the plants which he sees day by day. It is a revolt from the dry-as-dust teaching of botany. It cares little for science for science' sake, but its point of view is nature-study in its best sense. The book is divided into four parts, any or all of which may be used in the school: the plant itself; the plant in its environment; histology, or the minute structure of plants; the kinds of plants (with a key, and descriptions of 300 common species). The introduction contains advico to teachers. The book is brand new from start to finish.

"An exceedingly attractive text-book."-Educational Review.

"It is a school book of the modern methods."-The Dial.

"It would bo hard to find a better manual for schools or for individual use."-The Outlook.

\section{THE MACMILLAN COMPANY}

No. 66 Fifth Avenue

NEW YORK 


\section{THE CYCLOPEDIA OF AMERICAN HORTICULTURE: By L. H. BAILEY, of} Cornell University, assisted by WILHELM MILLER, and many expert cultivators and botanists.

\section{VOLS.-OVER 2600 ORIGINAL ENGRAVINGS-CLOTH-OCTAVO $\$ 20.00$ NET PER SET}

This great work comprises directions for the cultivation of horticultural crops and original descriptions of all the species of fruits, vegetables, flowers and ornamental plants known to be in the market in the United States and Canada. "It has the unique distinction of presenting for the first time, in a carefully arranged and perfectly accessible form, the best knowledge of the best specialists in America upon gardening, fruit-growing, vegetable culture, forestry, and the like, as well as exact botanical information. The contributors are eminent cultivators or specialists, and the arrangement is very systematic, clear and convenient for ready reference."

"Te have here a work which every ambitious gardener will wish to place on his shelf heside his Nicholson and his Loudon, and for such users of it a too advanced nomenclature would have been confusing to the last degree. With the safe names here given, there is little liability to serious perplexity. There is a growing impatience with much of the controversy concerning revision of names of organisms, whether of plants or animals. Those investigators who are busied with the ecological aspects of organisms, and also those who are chiefly concerned with the application of plants to the arts of agriculture, horticulture, and so on, care tor the names of organisms under examination only so far as these aid in recognition and identification. To introluce unnecessary confusion is a serious blunder. Professor Bailey has avoided the risk of confusion. In short, in range, treatment and editing, the Cyclopedia appears to be emphatically useful; . . . a work worthy of ranking by the side of the Century Dictionary."-The Vation.

This work is sold only by subscription, and terms and further information may be had of the publishers.

\section{THE MACMILLAN COMPANY}




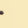






Webster Family Library of Veterinary Medicine Cummings School of Veterinary Medicine at Tufts Iniversity 200 Westboro Road North Grafton, MA 01536

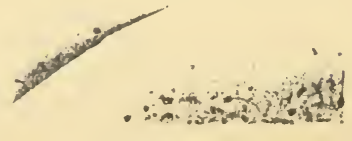




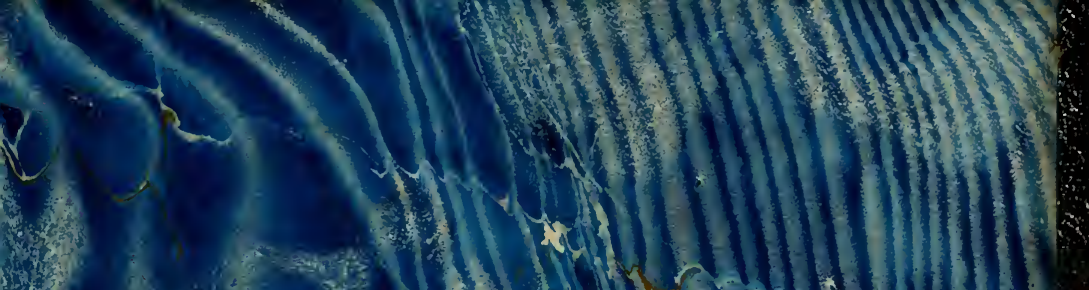


